\title{
REVIEW AND SUMMARY OF
}

\section{SOLAR THERMAL CONVERSION}

\section{PROGRAM PLANNING ASSISTANCE}

Lto dod v/16/75 $1000 / 8-\alpha$ MASTER

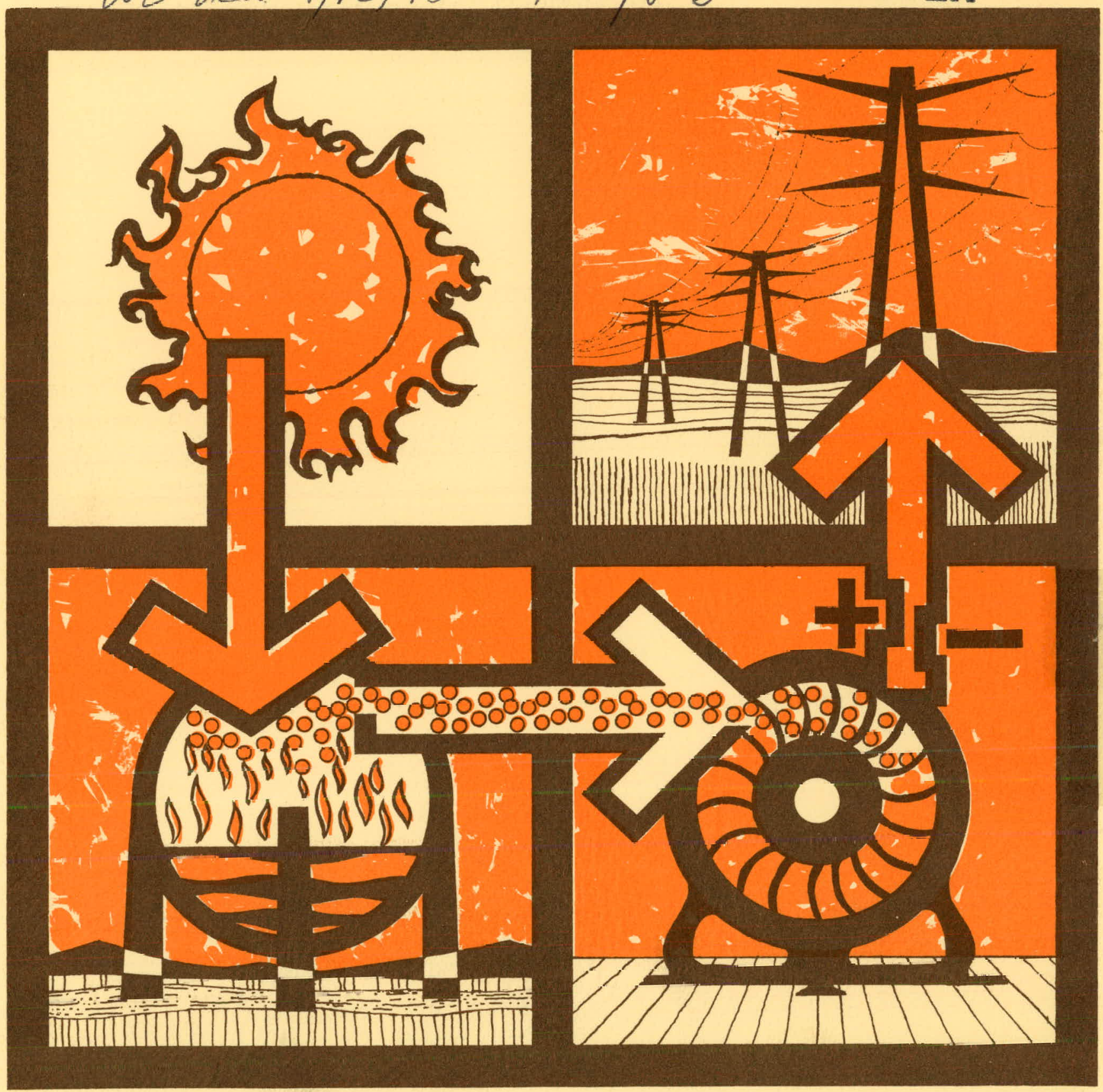

\section{THE AEROSPACE CORPORATION}




\section{DISCLAIMER}

This report was prepared as an account of work sponsored by an agency of the United States Government. Neither the United States Government nor any agency Thereof, nor any of their employees, makes any warranty, express or implied, or assumes any legal liability or responsibility for the accuracy, completeness, or usefulness of any information, apparatus, product, or process disclosed, or represents that its use would not infringe privately owned rights. Reference herein to any specific commercial product, process, or service by trade name, trademark, manufacturer, or otherwise does not necessarily constitute or imply its endorsement, recommendation, or favoring by the United States Government or any agency thereof. The views and opinions of authors expressed herein do not necessarily state or reflect those of the United States Government or any agency thereof. 


\section{DISCLAIMER}

Portions of this document may be illegible in electronic image products. Images are produced from the best available original document. 
DISCLAIMER

This book was prepared as an account of work sponsored by an agency of the United States Gom

weitrer the United States Government nor any agency thereof, nor any of their employeess

compleseness or or indied. Or assumes any legal liability or responsibility for the accuraty

represents that its use noutt not infrinoe priva, apparatus, product, or process disclosed, of

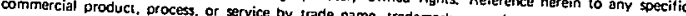

not necessarily constitute or imply its endorsente

States Government of any agency thereot. The views and opinions or on. or fovoring by the United

necessarily state or reflect those of the United States Governoment

REVIEW AND SUMMARY

OF

SOLAR THERMAL CONVERSION

PROGRAM PLANNING ASSISTANCE

Prepared for:

Energy Research and Development Administration

Division of Solar Energy

Solar Thermal Branch

Washington, D.C.

June 1975

Prepared by:

Energy and Resources Division

The Aerospace Corporation

El Segundo, California

Telephone: (213) 648-5615

$E Y-76-C=03-1080$

Letter Contract No. AT/04-3/-1080 
2.0 BASIC SOLAR THERMAL PROGRAM PLAN, ANNUAL THRU FY 1981

Major Results and Key Decision Dates

Budget Summary

Solar Thermal Program Summary

Central Receiver Power Plant

Solar Thermal Test Facilities

Solar Total Energy System

Distributed Collector Power Plant

Hybrid Solar Thermal Systems

Research and Development

Program Support

3.0 ALTERNATIVE FUNDING PLANS, ANNUAL THRU FY 1981

Plan.\#1, \$20.9M

Plan \# 1, \$13.2M

Plan \#2, $\$ 20.9 \mathrm{M}$

Plan \#2, \$13.2M

4.0 BASIC PROGRAM PLAN, ANNUAL THRU FY $1985 \quad 48$ Funding Requirements 49

Element Funding Requirements $\quad 50$

Expense Summaries

Major Results, Key Decision Dates, and Rudget. Summary

5.0 REVISED SCHEDULE/FORMAT PLAN SUMMARY OF 14 MAY 1975 
TABLE OF CONTENTS (Continued)

Page

APPENDIX A - Memoranda, Directives, and Notes of Instruction for "Phase II" Budget Submissions A-l

Responsibilities for "Phase 3" Solar Reports - 3/6/75

$A-2$

Objectives, Strategy, and Issues

A-4

Helpful Hints for Preparing Objectives

A-6

Strategy Considerations for Energy R\&D Programs

A-9

Program Implementation

A- 11

Program Element Summary Sheet

A-13

ERDA Coordinators

A -14

Program Unit Titles

A -15

Program Outputs and Projections (Exhibits 1-6)

A-16

Fiscal Year 76 Equipment Budget - 3/11/75

A-22

Preparation for the First Meeting of the NAS Study Committee - 3/19/75

Call for Agency Planning and Budgeting Information $3 / 21 / 75$

Program Implementation Schedule - 3/19/75

A-25

General Instructions for Preparation of Material for Program Unit Descriptions - 3/20/75

A-3 1

Instructions for Preparation of Material for Program Outputs/Milestones

A -35

Outline of Meeting with Senior Planning Group - 5/13/75

A-39

"Oil and Gas Extraction" Example Program Sub-Unit

$A-41$

APPENDIX B - Solar Electric Applications "Phase III" Budget Submissions

B - 1

March 21, 1975, Draft

$\mathrm{Bl}-1$

March 20, 1975, Draft

B2-1

April 5, 1975, Draft

B 3-1 


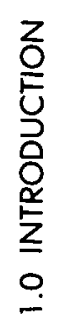




\subsection{INTRODUCTION}

The Solar Thermal Conversion Program comprises a major part of the national solar energy program which must be continuously reviewed and modified where necessary. Modifications are typically required to reflect technical achievements and uncertainties which arise from within the program or from other technical programs, changes in budgets available for supporting the program as well as internal program funding priorities, changing goals.such as through acceleration or stretch-out of the program schedule, significant organizational changes involving responsible governmental agencies, the introduction of new project management support contractors, and required budget or schedule changes occurring within individual projects that make up the Solar Thermal Conversion Program. The Aerospace Corporation has provided data to assist in planning, review, coordination, and documentation of the overall Solar Thermal Conversion Program by performing the following activities:

A. The objectives, goals, top level schedules, and major program structure have been updated in the form of the accompanying Program Plan. This Program Plan includes the major organizational and technical advances since publication of the most recent "Five Year National Solar Energy Program" plan in early 1974. Specific projects and probable Project Management Contractors have been identified which include:

Central Receiver Proof-of-Concept Experiment Project (1st generation concept)
The Solar Thermal Test Facility (Central Receiver Concept)

Solar Total Energy Test Bed
Sandia Corporation Livermore, California

Naval Weapons Center. China Lake, California Sandia Corporation Albuque rque, N. M.

B. As part of the preparation of the Program Plan, alternatives were identified and compared. Specific recommendations were developed. Factors that were considered in the identification of alternatives include:

(1) The objectives, schedules, and funding requirements for individual projects (e.g., the Central Receiver Pilot Plant 
Project) and the major elements of each project (e.g., the Subsystem Research Experiments of the Central Receiver Pilot Plant).

(2) The technical, cost, and schedule risks associated with major project elements.

(3) The dissemination and utilization in industry of the technology developed within the Solar Thermal Program.

C. The Program Plan was prepared in accordance with the memoranda, directives, schedules, and notes of instruction from Dr. LaGassie and Dr. Mock. These directives are included as Appendix A of this report.

Sections 2.0 through 5.0 cover the discussion and detail planning covering the objectives, justification, basic and alternative plans, budgets, and schedules for the Solar Thermal sub-unit portion of the Solar Electric Applications effort. Appendices B1, B2, and B3 include the March 21 , March 28, and April 5, 1975, Program Plan submissions of the complete Solar Electric Applications effort. In Appendix B the Solar Thermal, Solar Photovoltaic, Wind Energy, and Ocean Thermal sub-unit texts have been condensed and formatted for integration in the overall ERDA budget package. 


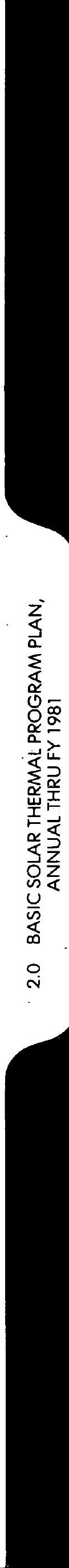


SECTION 2.0 BASIC SOLAR THERMAL PROGRAM PLAN, ANNUAL THRU FY 1981

The basic program plan for the Solar Thermal subprogram contains: a milestone chart, titled "Major Results and Key Decision Dates," summarizing the major events for each of the subprogram elements (e.g., central receiver power plant decision to build $10 \mathrm{MWe}$ pilot plant, pilot plant checked out and operating, decision to build $100 \mathrm{MWe}$ demonstration plant);

(2) Table I, "Budget Summary Solar Thermal Subprogram" detailing the fiscal year dollar expenditures for each subprogram element through FY 1981 with a FY 1976 budget of $\$ 29.5$ million;

(3) a Solar Thermal Subprogram "Project Summary Sheet" identifying the objectives, justification, strategies, task description, approach; major results, and total funding; and

(4) two versions of the "Program Element Summary Sheets." The first version is a one-page summary as backup support for the congressional budget and second version, up to seven pages in length, provides project descriptions and detailed task funding and schedules required to develop the one-page summary. The Element Summaries are ordered as follows:

Project Index

Title

(a) Central Receiver Power Plant Number.

(b) Golar Tlieinal Tesl Facilities $\mathrm{V}-5-1$

(c) Solar Total Energy Systems $\mathrm{V}-\mathrm{A}-2$

(d) Distributed Collector Power Plant

$\mathrm{V}-\mathrm{A}-3$

(e) Hybrid Solar The rmal Systems $\mathrm{V}-\mathrm{A}-4$

(f) Research and Development $\mathrm{V}-\mathrm{A}-5$

(g) Program Support $\mathrm{V}-\mathrm{A}-6$ $\mathrm{V}-\mathrm{A}-7$

In general, the material in Section 2.0 flows from the presentation of the overall basic Solar Thermal Subprogram Plan to successively more detailed descriptions of the individual projects, subprojects, and elements. 
SOLAR THERMAL SUBPROGRAM

MAJOR RESULTS AND KEY DECISION DATES

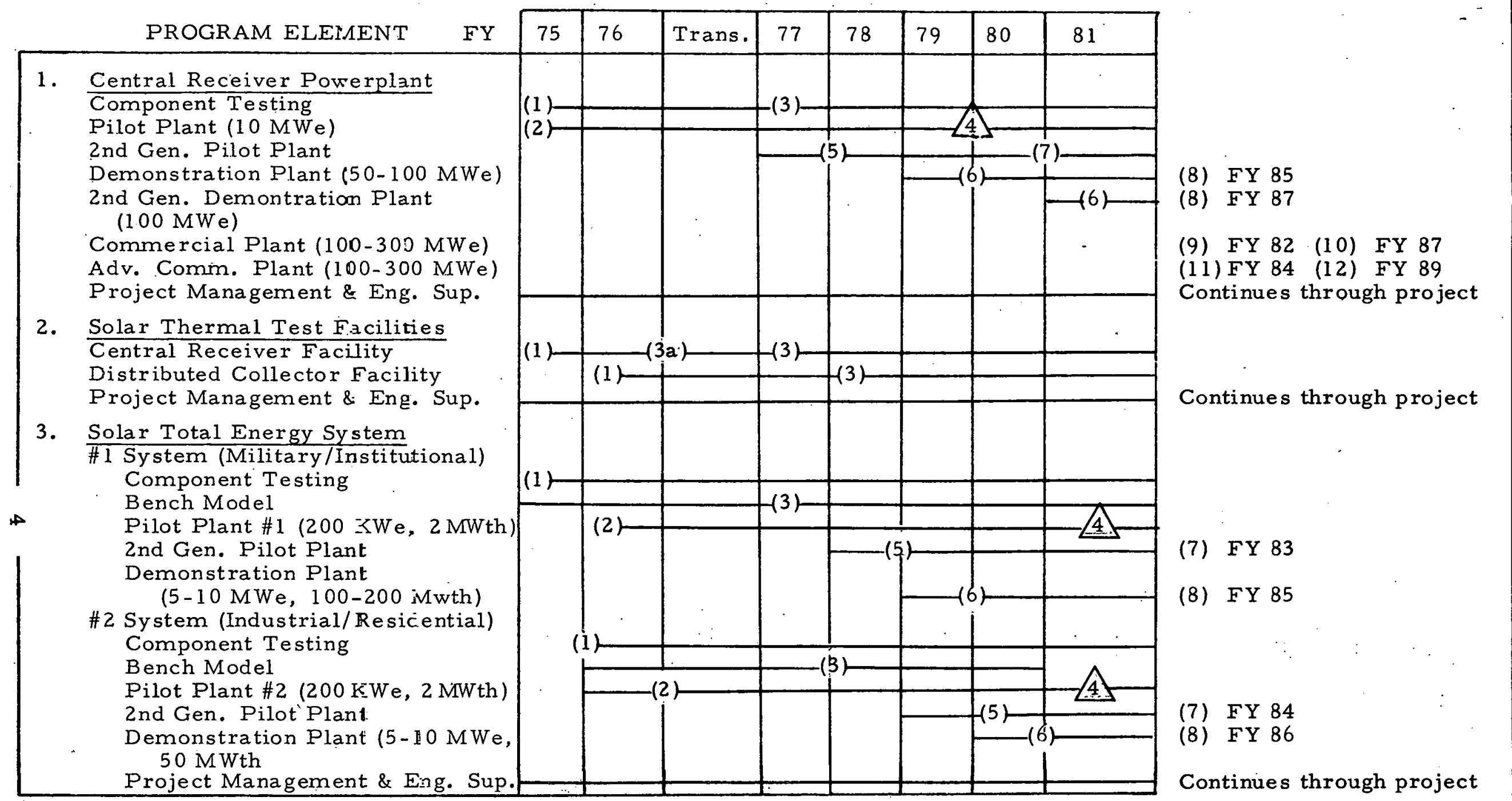

\section{Milestones}

(1) Decision to Build Eiench Mode1/Test Facility

(2) Decision to Build Pilot Plant

(3) Bench Model/Facility in Operation (3a) Partial Cafability

4 Pilot Plant Checked Out and Operating

(5) Decision to Start Second Generation Pilot Plant

(6) Decision to Burld Demorstration Plants
(7) Second Generation Plant in Operation

(8) Demonstration Plant in Operation

(9) Decision to Build Commercial Plant

(10) Commercial Plant in Operation

(11) Decision to Build Advance Comm. Plant

(12) Advance Comme rcial Plant in Operation 
SOLAR THERMAL SUBPR OGRAM

MAJOR RESULTS AND KEY DECISION DATES (Cont'd)

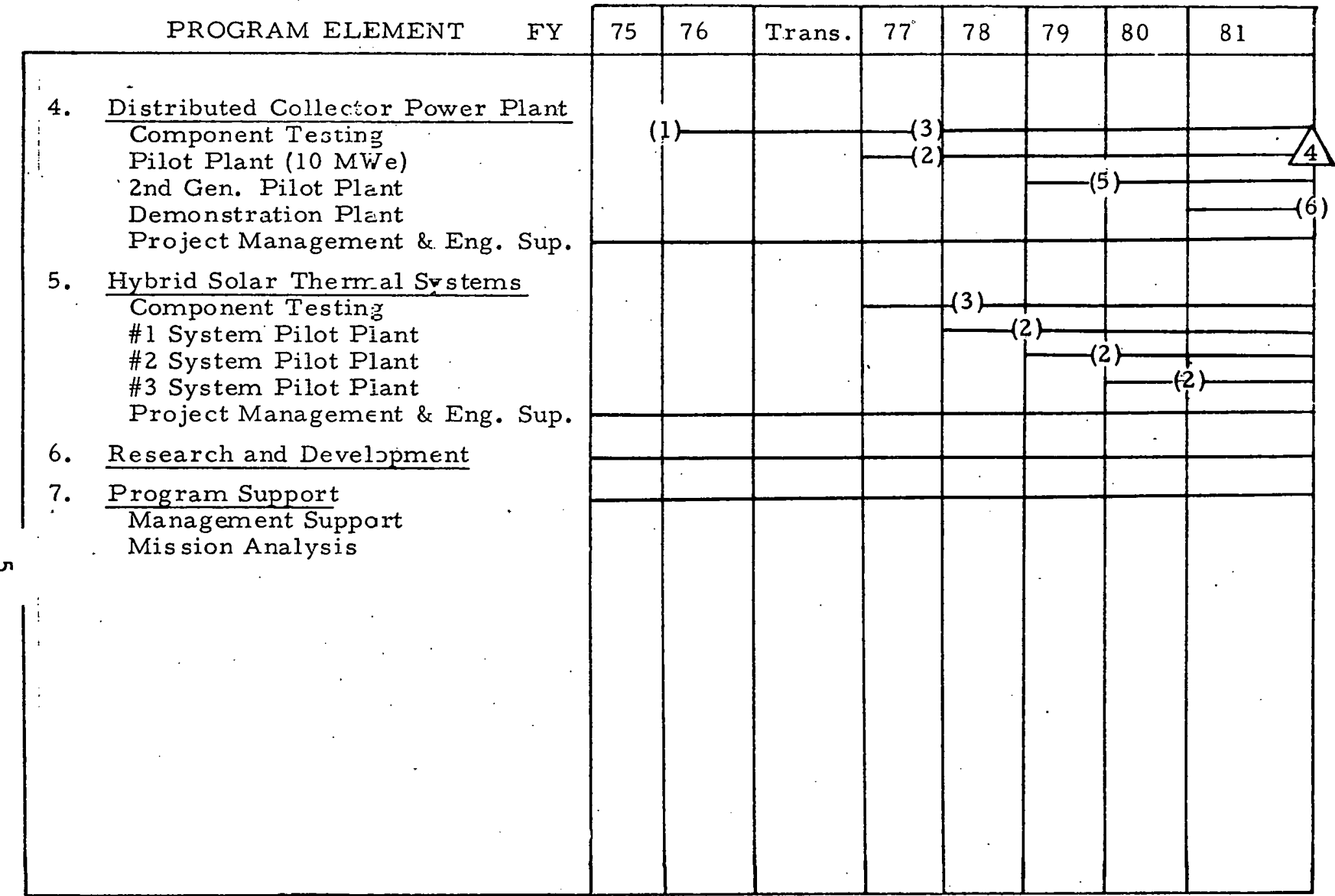

(7) FY 82

(8) FY 87

Continued throughoproject

(4) FY 82

(4) FY 83

(4) FY 84

Continued through project

Continued through project

\section{Milestones}

(1) Decision to Build Bench Model/Test Facility

(2) Decision to Build Pilot Plant

(3) Bench Model/Facility in Operation

4 Pilot Plant Checked out and Operating
(5) Decision to Start Second Generation Pilot Plant

(6) Decision to Build Demonstration Plants

(7) Second Generation Plant in Operation.

(8) Demonstration Plant in Operation 
BASIC PLAN

FY $1976 \$ 29.5 \mathrm{M}$
TABLE 1

BUDGET SUMMARY

SOLAR THE RMAL SUBPROGRAM

(19

\begin{tabular}{|c|c|c|c|c|c|c|c|}
\hline 75 & 76 & Trans. & 77 & 78 & 79 & 80 & 81 \\
\hline & $\begin{array}{r}7.0^{\#} \\
1.8\end{array}$ & $\begin{array}{l}1.5 \\
0.4\end{array}$ & $\begin{array}{l}3.5 \\
8.9 \\
1.3\end{array}$ & $\begin{array}{r}3.9 \\
18.3 \\
8.4\end{array}$ & $\begin{array}{r}2.5 \\
14.6 \\
14.6 \\
0.8\end{array}$ & $\begin{array}{c}2.5 \\
3.4 \\
14.6 \\
5.2 \\
1.7\end{array}$ & $\begin{array}{r}2.0 \\
1.7 \\
3.4 \\
14.7 \\
4.2\end{array}$ \\
\hline & 0.8 & 0.2 & 1.3 & 2. 8 & 3.2 & 2.5 & 2.2 \\
\hline & $\begin{array}{l}4.5 \\
1.7 \\
0.6\end{array}$ & $\begin{array}{r}1.2 \\
.4 \\
0.2\end{array}$ & $\begin{array}{r}19.6 \\
11.5 \\
2.8\end{array}$ & $\begin{array}{l}5.4 \\
3.6 \\
0.8\end{array}$ & $\begin{array}{l}3.5 \\
2.5 \\
0.5\end{array}$ & $\begin{array}{l}2.7 \\
2.7 \\
0.5\end{array}$ & $\begin{array}{l}2.7 \\
2.7 \\
0.5\end{array}$ \\
\hline & $\begin{array}{l}1.7 \\
0.7 \\
0.3\end{array}$ & $\begin{array}{l}0.4 \\
0.1 \\
0.1\end{array}$ & $\begin{array}{l}2.4 \\
2.5 \\
2.2\end{array}$ & $\begin{array}{l}2.0 \\
3.1 \\
2.9 \\
1.5\end{array}$ & $\begin{array}{l}2.3 \\
2.9 \\
5.3 \\
4.4 \\
0.8\end{array}$ & $\begin{array}{l}1.7 \\
2.5 \\
8.0 \\
6.5 \\
2.4\end{array}$ & $\begin{array}{l}1.7 \\
2.5 \\
1.7 \\
6.1 \\
14.2\end{array}$ \\
\hline & $\begin{array}{l}1.7 \\
0.7 \\
0.3\end{array}$ & $\begin{array}{l}0.4 \\
0.1 \\
0.1\end{array}$ & $\begin{array}{l}2.4 \\
1.4 \\
3.2\end{array}$ & $\begin{array}{l}3.1 \\
3.6 \\
3.2\end{array}$ & $\begin{array}{l}2.9 \\
3.8 \\
4.2 \\
2.2\end{array}$ & $\begin{array}{l}2.5 \\
3.8 \\
7.7 \\
4.6 \\
0.8\end{array}$ & $\begin{array}{l}2.5 \\
5.2 \\
4.6 \\
4.2\end{array}$ \\
\hline & 0.5 & 0.1 & 1.2 & 1.8 & 2.5 & 3.3 & 3.3 \\
\hline
\end{tabular}

1. 7 through FY 82

3. 4 through FY 83

80 to 150 through FY 85

90 to 160 through FY 86 **

130-390 through FY $88^{*}$ 130-340 through FY $89^{*}$

14. 0 through FY 86

8. 4 through FY 85 8.4 through FY 85

1. 7 through FY 85

3. Solar Total Energy System

\#1 System (Militar/Institutional)

Component Testing

Bench Model

Pilot Plant \#l (c.00 KWe, $2 \mathrm{MWth})$

2nd Gen. Pilot Plant

Demonstration Plant

(5-10 MWe, ! 00-200 Mwth)

\#2 System (Industrial/Residential)

Component Testing.

Bench Model

Pilot Plänt \#2 ( $200 \mathrm{~K} N e, 2 \mathrm{MW}$ th $)$

2nd Gen. Pilot Plant

Demonstration Plant (5-10 MWe, $50 \mathrm{MWth}$

Project Management \&. Eng. Sup.

* Not included in runout past 1989

\#Includes allocation of $\$ 1 \mathrm{M}$ from Solar Storage 1976 budget item
1.7 through FY 82 3.4 through FY 83 40-80 through FY 86

1. 7 through FY 82 12. 5 th rough FY 85 60-120 through FY 88 * 5.6 through FY 86 
TABLE 1

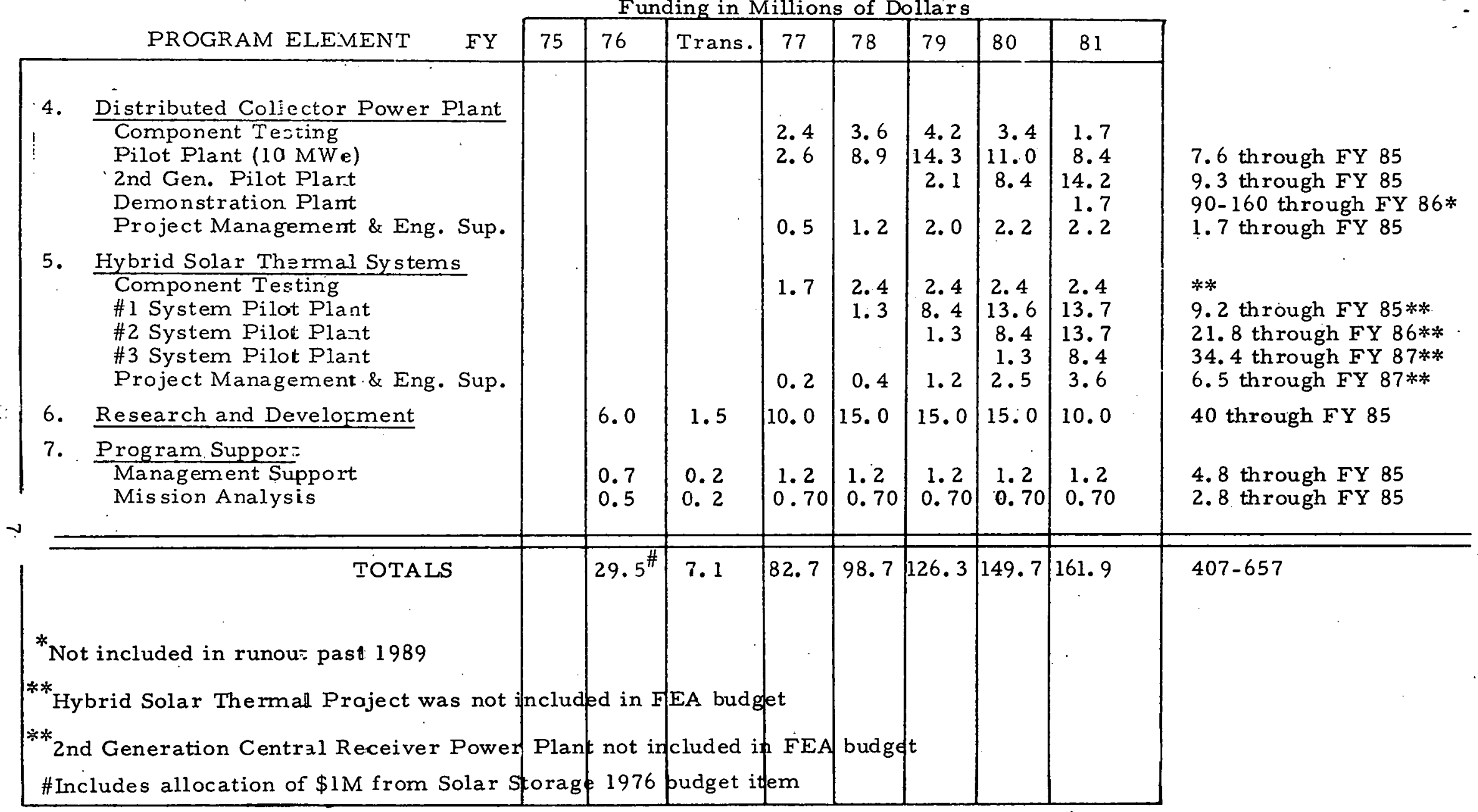




\section{PROJECT SUMMARY SHEET}

Program Element Index Number and Title: V Solar Electric Applications

Project Index Number and Title: V-A Solar Thermal

Project Objective: To provide full system capability for:. 1) economical and natural resource conserving production of supplemental electric power in the 1980's, and 2) total energy systems for urban/rural communities and industrial/institutional/military centers at competitive rates.

Project Justification: Few fundamental technical limitations. Analyses indicate that solar thermal power plants can be competitive with fossil fuels and total energy systems should be competitive with conventional energy sources in the 1980's.

Project Strategy: Develop and demonstrate the economically competitive capabilities for solar thermal systems compared to fossil fuel operations. Industry/utilities to participate in research and development to expedite commercial development.

Description of Task and Fipproach: Development and demonstration of central receiver power plant, solar total energy systems, distributed collector power plant, hybrid solar thermal systems. Solar thermal test facilities, research, development and program support are included.

Major Results and Key Decision and Dates:

Central Receiver Power Plant 10MWe Pilot Plant checked out \& operating

Decision to build 100-300Mlle Commercial Central Receiver Power Plant

200KWe/2MI/th Solar Total Energy System Pilot Plants checked out \& operating

10MWe Distributed Collector Power Plant Pilot Plant. checked out \& operating

Hybrid Solar Thermal-Systems pilot plants (3) checked out and operating

1983

40,000 iwe Soiar Thermal powers: gerieration by 400 connercial plants saving:

2000

: Task Funding (1977 dollars):

\begin{tabular}{|c|c|c|c|c|c|c|c|c|c|c|c|}
\hline & & FY & 1976 & $\begin{array}{l}\text { Transi } \\
\text { Peri } \\
\end{array}$ & $\begin{array}{l}\text { tion } \\
\text { od } \\
\end{array}$ & & & & & & Through \\
\hline & FY75 & Cong. & Rev. & Cong. & Rev. & FY77 & FY78 & FY79 & FY80 & FY81 & Completion \\
\hline Operating Expenses & 10.0 & & $28.0^{\#}$ & & 6.1 & 47.3 & 56.1 & 66.2 & 77.4 & 75.2 & 150.2 \\
\hline Capital Equipment & & - & 0.7 & & 0.2 & 11.9 & 16.5 & 27.9 & 32.2 & 49.3 & 107.0 \\
\hline Computers & & & & & & & & & - & & \\
\hline Other Equipment & & & & & & & & & & & \\
\hline Plant Construction & & & 0.8 & & 0.8 & 24.3 & 27.1 & 32.2 & 40.1 & 37.5 & 329.0 \\
\hline $\begin{array}{l}\text { ass-Through Funding } \\
\text { oint Funding }\end{array}$ & & & & & & & & & & & $(330-790)^{\star}$ \\
\hline TOTAL & & & 29.5 & & 7.1 & 83.5 & 99.7 & 126.3 & 149.7 & 162.0 & 586.2 \\
\hline
\end{tabular}

* Utilities anticipated contribution to demonstration and commercial plant developments (not included in total)

\# Includes allocation of $\$ 1 \mathrm{M}$ from Solar Storage 1976 budget item 


\section{Sub-Program Unit: Solar Thermal}

\section{Program Element Index Number and Title: $\mathrm{V}-\mathrm{A}-1$ Central Receiver Power Plant}

Program Element Objective: To provide stimulation to utilities sufficient to result in several 100 to 300 lil!e commercial plants in operation by 1990.

Program Element Justification: Electric utilities have expressed interest in this project and are expected to contribute to the construction of commercial plants following demonstration of the technical and economic feasibility. Electric Power Research Institute has recommended that priority be given to this development over all others SEA sub program elements. The high capital expenditure requirements dictate these demonstrations.

Program Element Justification: Electric utilities have informally expressed interest in this project and are expected to contribute to the construction of commercial plants following demonstration of the technical and economic feasibility. The high capital expenditure requirements dictate these demonstrations.

Program. Element Strateqy: Major hardware development wi 11 be funded by ERDA with electric utilities beginning to contribute significantly at the demonstration plant stage. Busbar generation of electricity at the price of 25 to. 30 mills per KWh is desired.

Description of Task and Approach: Hardware development and testing is currently being conducted and planning for a lOMWe pilot plant is in work and expected to be constructed and tied into utility grids in 1979. A 100MWe demonstration plant and a second generation plant will follow. These plants will utilize a pressurized steam Rankine cycle initially and probably an air or gas Brayton cycle in the second gerieration. Severa 1 comercjajepjants in the 100. to 300 MW capacity range are expected to follow.

Major Results and Key Decision Dates:

Decision to build lomke pilot plant Bench model test facility

Second generation pilot plant decision

l00MW demonstration plant decision

Second generation pilot plant decision

First commercial plant decision

Advanced commercial plant decision Program Element Funding (1977 dollars):

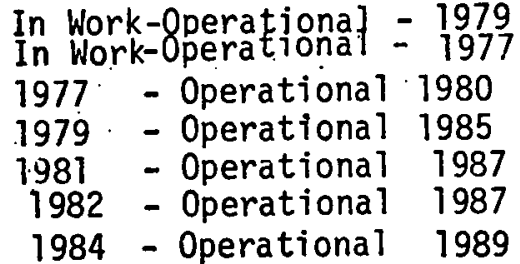

Transition

Operating Expenses

FY 1976

$\frac{\text { FY75 }}{5.1}$ Cong. $\frac{\text { Rev. }}{9.6} \frac{\text { Cong. }}{2.1} \frac{\text { Rev. }}{7.1} \frac{\text { FY77 }}{9.1} \frac{\text { FY78 }}{10.7} \frac{\text { FY79 }}{17.3} \frac{\text { FY80 }}{10.2 ~ 20.1 M}$

Capital Equipment

\section{Computers}

Other Equipment

Plant Construction

Pass-Through Funding

Joint Funding

TOTAL

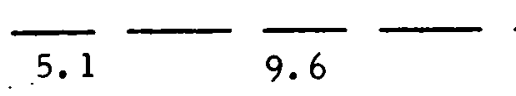

$\begin{array}{llll} & 0.5 & 0.8 & 0.5 \\ 2.9 & 9.1 & 9.8 & 4.6\end{array}$

$\begin{array}{llll}5.0 & 14.7 & 14.4 & 7.5\end{array}$

$5.0 \quad 50.0$

$5.0 \quad 250.0$

Guidance on Pass-Through and Joint Funding: Possible indsutry funding of $50 \%$ of demonstration plant should be encouraged.

Fire, Safety and Other Requirements: Evaluation of safety/building/environmental codes unique to solar thermal not included in these plans. 
Subprogram. Solar Thermal - V-A.

Project Index Number. $\quad V-A-1$.

Project Title. Central Receiver Power Plant.

Project Objective. To provide a full system capability for the widespread production of supplementary electric power in the 1980s to meet electric utility requirements for load - following or intermediate load electric generating systems which are capable of supplying power at economical prices while simultaneously conserving natural resources.

Project Justification. The higher initial capital expenditure required for solar thermal conversion plants when compared to conventional fossil fuel plants requires that the economic feasibility be demonstrated before private capital sources will make the necessary commitments.

Project Strategy. The major hardware developments will be funded by ERDA through industry with increasing support by the electric utilities as the project progresses. overali program planning and mission systell analysis support froli the Rerospace Corporation, an FCRC project direction by the ERDA Laboratory with program management retained by ERDA.

Description of Task. The project was initiated in 1973/1974 with four parallel control network system design studies funded by NSF through industry. In 1975 three parallel contracts were awarded to industry for subsystem hardware development (component testing) and for a preliminary design of a 10 megawatt electric (MWe) pilot plant. This subsystem hardware will be tested at the Solar Therma Test Facility (Project Index Number V-A-2). In 1977 a contract will be initiated with industry for the contraction of a 10 Mle pilot plant which will be tied into a utility grid in 1979. Some electric utilities have informally indicated interest in participating in the critical receiver pilot plant, and the extent of this participation is being explored. The initial pilot plant which utilizes steam and a Rankine cycle will be followed by a second generation $10 \mathrm{MWe}$ pilot plant probably utilizing air or a gas and the Brayton cycle. Design of a 100 MWe demonstration plant will be initiated in 1979. The plant will become operational in 1985. It is anticipated that the demonstration plant will be funded up to $50 \%$ private capital (the utilities). The demonstration plant will verify the technical and.economic feasibility of the central receiver solar thermal conversion intermediate load electrical power plant. 
Upon completion of the demonstration plan the plant will be handed over to the participating utility for use as a commercial plant. The 100 MWe demonstration plant is followed by the advanced demonstration plant and advanced commercial central receiver power plants. Several of these plants are to be operational by 1990 . It is anticipated that these commercial plants will be funded entirely with private capital. However, the initial generation of commercial control receiver plants may require a portion of the funds to be made available in low interest government backed loans in order to obtain the necessary larger initial capital required to build solar plants rather than conventional front face power plants. 
Task Funding (1977 dollars): V-A-1 CENTRAL RECEIVER POWER PLANT

\section{Transition}

FY 1976 Period

FY75 Cong. Rev. Cong. Rev. FY77 FY78 FY79 FY80 FY81 Completion

Subproject \# 1

COMPONENT. TESTS

Operating expenses $(3)$

7. $0^{\#}$

1.53 .5

2.9

2.5

2.52 .0

Capital equipment

Computers

Other equipment

Plant construction

Pass-through funding

Joint funding

SUBTOTAL

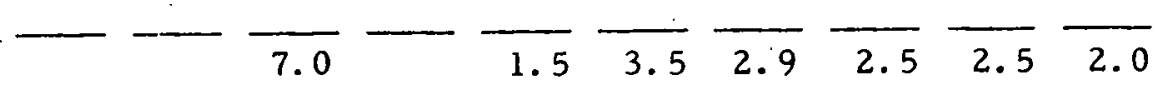

Subproject \#2

PILOT PLANT (10 MWe)

Operating expenses

1.8

0.4

2.0

2.2

3.4

1. 7

1.7 FY 82

Capital equipment

$2.96 .6 \quad 5.5$

Computers

Other equipment (1)

0.50 .5

6.15 .0

Plant construction

$5.0 \cdot 9.7 \quad 6.9$

Pass-through funding

Joint funding

SUBTOTAL

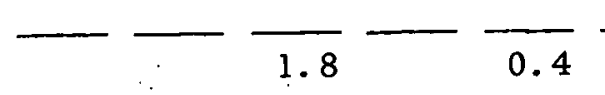

8. 9

$\overline{18.3} \overline{14.6}$

$\overline { 3 . 4 } \overline { 1 . 7 } \longdiv { 1 . 7 \text { FY } 8 2 }$

Subproject \#3

2nd GEN. PILOT PLANT (10 MWe)

Operating expenses

Capital equipment

Computers

Othe $r$ equipment ${ }^{(1)}$

$\begin{array}{lllllll}1.3 & 1.4 & 2.0 & 2.0 & 3.4 & 3.4 & \text { FY } 83\end{array}$

$3.0 \quad 5.15 .1$

- 0.30 .5

$3.0 \quad 4.8 \quad 4.6$

$\begin{array}{lll}5.0 & 7.5 & 7.5\end{array}$

Plant construetion

Pass-through funding

Joint funding

SUBTOTAL
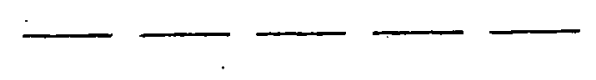

1.3

8.4

14.6

$14.6 \quad 3.4$

3. 4 FY 83

Guidance on Pass - Through and Joint Funding:

(1) Utility grid interface furnished by a utility; funding not included.

Fire, Safety, and Other Requirements:

(2) New codes may be required.

\# Includes allocation of \$1M from Solar Storage 1976 budget item 
Task Funding (1977 dollars): V-A-1 CENTRAL RECEIVER POWER PLANT (Continued) 'Transition

FY 1976 Cong: Rev. Cong. Rev. FY77 FY78 FY79 EY80 FY81 Completion

Subproject \#4

100 MWe DEMONSTRATION PLANT

Operating expenses

$\begin{array}{lllll}0.8 & 5.2 & 4.7 & 10 & \mathrm{FY} 86\end{array}$

Capital equipment

5. 012 FY 85

Computers

Other equipment

Plant construction

$5.0 \quad 60-130$ FY 85

Pass-through funding

Joint funding

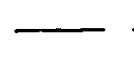

SUBTOTAL

Subproject \#5

ADVANCED $100 \mathrm{MWe}$

DEMONSTRATION PLANT

Operating expenses

$1.7 \quad 4.2 \quad 10$

Capital equipment

30

Computers

Other equipment

Plant construction

$50-120$ FY 86

Pass-through funding

Joint funding

SUBTOTAL
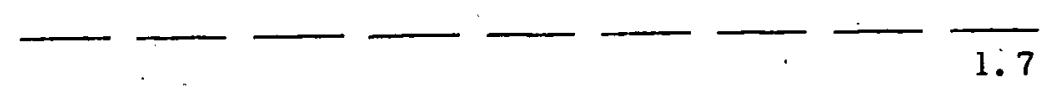

4.2

$90-160$ FY 86

Subproject \#6

COMMERCIAL PLANT 100-300 MWe

Operating expenses

Capital equipment

Computers

Other equipment

Plant construction

Pass-through funding

Joint funding

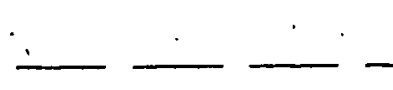

SUBTOTAL

(1) $\overline{130-390 \text { FY } 87}$

Guidance on Pass - Through and Joint Funding:

(1) Not included in run-out totals.

Fire, "Safety, and Other Requirements: 
Task Funding (1977 dollars): V-A-1 CENTRAL RECEIVER POWER PLANT (Continued) Transition

FY75 $\frac{\text { FY } 1976}{\text { Cong. Rev. }}$ Cong. Rev. FY77 FY78 EY79 FY80 FY81 Completion

Subproject \#7

ADVANCE COMMERCIAL PLANT (100-300 MWe)

Operating expenses

Capital equipment

Computers

Other equipment

Plant construction

Pass-through funding

Joint funding

SUBTOTAL
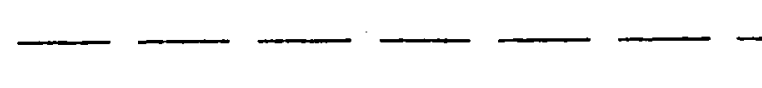

(1) $\overline{130-390 \text { FY89 }}$

Sủbproject \#8

PROJECT MANAGEMENT \& ENGINEERING SUPPORT (Sandia Livermore)

Operating expenses

0.8

0 .

1.3

2.83 .2

2.5

2. 214 FY86

Capital equipment

Computers

Other equipment

Plant construction

Pass-through funding

Joint funding

SUBTOTAL

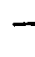

PROJECT TOTAL

Operating expenses

9.6

2.1

Capital equipment

$$
\begin{array}{lllll}
2.9 & 9.6 & 10.6 & 5.1 & 5.0
\end{array}
$$

Computers

$$
\begin{array}{rrr}
.5 & .8 & .5
\end{array}
$$

Othe $r$ equipment

Plant construction

$$
\begin{array}{llllll}
5.0 & 14.7 & 14.4 & 7.5 & 5.0
\end{array}
$$

Pass-through funding

Joint funding

TOTAL

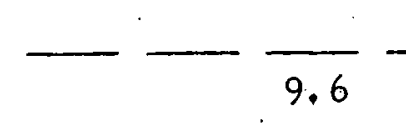

$\overline{2.1} \overline{15.0}$

$\overline{33.4} \overline{35.7} \overline{29.9}$

$28.2189-259$ FY86

Guidance on Pass-Through and Joint Funding:

(1) Not included in run-out totals.

Fire, Safety, and Other Requirements: 
DIRECT SOLAR CONVERSION PROGRAM UMIT

PROGRAM ELEMENT SUMMARY SHEET

Sub-Program Unit: Solar Thermal

Program El=-erit Index Nutiner ard Title: V-A-2 Solar Thermal Test Facilities

Program E:erant Objective: To provide test facilities for component and subsystem hardware (model or module level for pilot and demonstration plant hardware) of central receiver and distributed collector power plant systems.

Program Element Justification: To provide early verification of alternative solutions to component and subsystem hardware design requirements and thereby reduce program risk and accelerate schedule at miminum cost.

Program Element Strategy: Develop a 5MW thermal central receiver facility capable of doing scale model studies of hardware. In same site develop distributed collector facility utilizing facilities and services jointly with central receiver: facility when feasible.

Description of Task and Acoroach: An initial lMW thermal central receiver will be constructed for early testing followed by establishment of a full 5MW capability facility. This facility will be developed and built by industrial contractors. A distributed collector system will also be developed to facilitate component testing. Major Results and Key Decision Dates:

Decision to build central receiver facility Decision to build distributed receiver facility Test of first generation pilot hardware In Work Operational 1977 1976 Operational 1978 1977

Program Element Funding (1977 dollars):

\section{Transition}

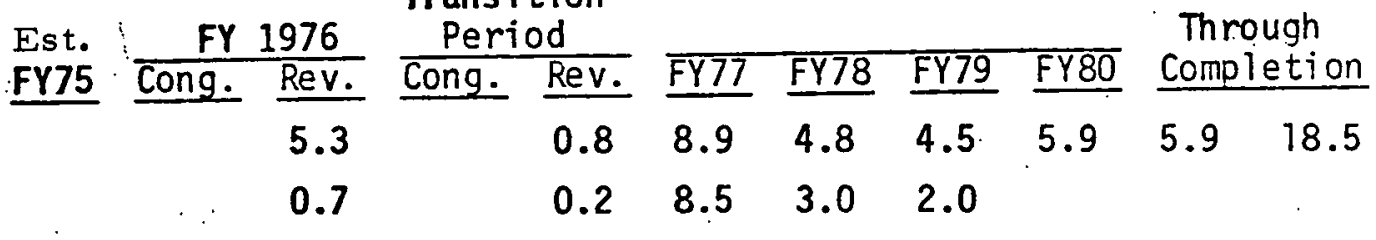

Operating Expenses

Capital Equipment

Computers

Other Equipment

Plant Construction

Pass-Through Funding

Joint Funding

TOTAL $\begin{array}{llll}0.8 & 0.8 & 16.5 & 2.0\end{array}$

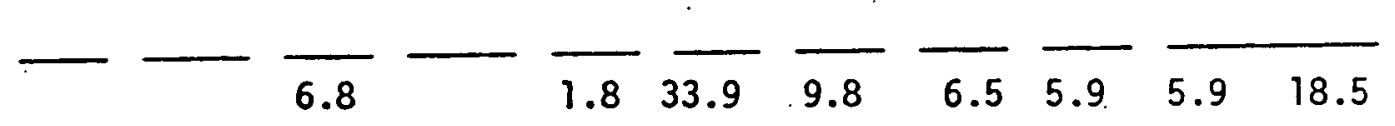


Program Element Objective: To provide solar therinal test facilities to test the components and subsystem hardware that is either a model or module of both the pilot plant and the demonstration plant hardware. If a model or module is used, the test data must be scalable for use in both pilot plant and demonstration plants. Separate test facilities are required for both the Central Receiver Power Plant and the Distributed Collector Power Plant due to the inherent differences in the basic design and potential performance differences of the two types of plants. To obtain a precise comparison between the two types of plants it is an objective to have the two test facilities receive the same insolation.

Program Element Justification: To reduce the program risk and cost, and to accelerate the program schedule, it is required that a solar thermal test facility be available early in the program to test many varied but parallel technological approaches to the components and subsystem hardware required for solar thermal power plants. The most promising component and subsystem hardware will then be selected for the pilot plant design and construction.

Program Element Strategy: Recent mission analysis studies utilizing industry and university design parameters and performance have shown the Central Receiver Power plant to be the preferred (highest efficiency and lowest. cost) solar thermal conversion electric power plant. The approach is to provide a Solar Thermal Test Facility for models or modules central receiver hardware the results of which will be scaliable and used for detail design of a lOMWe Central Receiver Pilot Plant. Scaling studies of the various hardware subsystems and components have shown that a $5 \mathrm{MW}$ thernal Solar Test Facility is required. This should be constructed in two stages, a $1 M W$ thermat for early testing followed by the 5MW thermal full capability one year later. The Central Receiver Test Facility will be followed by a parallel development of the Distributed Collector Test Facility. The selection of the same site for the two test facilities could appreciably reduce the costs and development time required for supporting constructions of roads, utilities, cafeteria, etc.

Description of Task and Approach: The first task is the preparation by an architecture and engineering firm of the conceptual design, detail design and specifictions required for the construction and fabrication of the $5 \mathrm{MW}$ thermal Central Receiver Test Facility. Funds for the construction, fabrication and operation of the test facility will be transferred to the Naval !!eapons Center (NWC) China Lake, Cal ifornia. NWC Will advertise for bid, award, supervise and operate the test facility as directed by ERDA. Monies required by industry to support testing of the component and subsystem hardware will be funded directly to industry by ERDA as part of the development hardware cunlracts. Following the Central Receiver Test Facility by about 9 months a similar approach wil1 be taken for the Distributed Collector Test Facility. A location has not been identified for the second facility. However, costs, schedule, insolation and required supporting facilities would deem selection of the same facility location most desirable.

Major Results and Key Decision Dates: The performance evaluation of the central Receiver Pilot Plant in 1979 dictates the following schedule:

Award A\&E facility design

Transfer of supervision, construction \& operation of facility to NWC

Award of (IMW thermal) heliostate subsystem contracts by NWC

Award of facility construction contract

Award of (5MW thermal) heliostat fabrication contract

IOC for TMW thermal test facility

Test of ist generation pilot plant hardware

IOC for 5MW thermal test facility

in work Ju1 75

Sep 75

Spring 76

Ju1 76

Dec 76

Jan-Jul 77

Jul 78 . 
Task Funding (1977 dollars): V.-A-2 SOLAR THERMAL TEST FACILITIES

Transition

FY75 $\frac{\text { FY } 1976}{\text { Cong. Rev. }}$ Cong. Rev. FY77 FY78 EY79 EY80 FY81 Completion

FY75 $\frac{\text { FY } 1976}{\text { Cong. Rev. }} \frac{\text { Period }}{\text { Cong. Rev. FY77 FY78 EY79 FY80 FY81 Completion }}$

Subproject \# 1

CENTRAL RECEIVER FACILITY

Operating expenses

3.0

0.23 .6

2. 4.2 .5

2. 7

2.7

8. 4 FY 85

Capital equipment

0.7

0.2

$\begin{array}{lll}4.0 & 2.0 & 1.0\end{array}$

Computers

(1.0) (1.0)

Other equipment

(3.0) $(1.0)$

Plant construction

0.8

$\begin{array}{lll}0.8 & 12.0 \quad 1.0\end{array}$

Pass-through funding

Joint funding
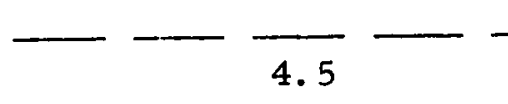

$1.2 \overline{19.6} \overline{5.4} \overline{3.5}$

$2 . 7 \longdiv { 2 . 7 }$

8. 4 FY85

SUBTOTAL

Subp ̀े oject \#2

DISTRIBUTED COLLECTOR FACILITY

Operating expenses

1.7

0.4

$2.5 \quad 1.6 \quad 1.5$

2.7

2. 7

8. 4 FY85

Capital equipment

$4.5 \quad 1.0 \quad 1.0$

Computers

Other equipment

Plant construction

4. 51.0

Pass-through funding

Joint funding.

SUBTOTAL
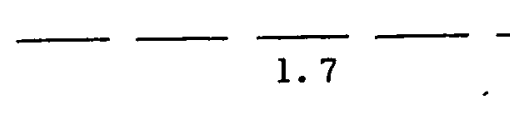

$\overline{0.4} \overline{11.5} \overline{3.6}$

$\overline{2.5}$

2.7

2.7

8. 4 FY 85

Subproject \#3

PROJECT MANAGEMENT AND ENGINEERING SUPPORT

Operating expenses

0.6

$0.2 \quad 2.8$

0.80 .5

0.5

0.5

1.7 FY 85

Capital equipment

Computers

Othe $r$ equipment

Plant construction

Pacc-through funding

Joint funding

SUBTOTAL

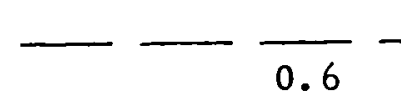

$\overline{0.2} \overline{2.8} \overline{0.8}$

$\overline{0.5} \overline{0.5}$

0.5

1. 7 FY 85

Guidance on Pass-Through and Joint Funding:

Fire, Safety, and Other Requirements: 
Task Funding (1977 dollars): V-A-2 SOLAR THERMAL TEST FACILITIES (Continued) Transition

FY75 $\frac{\text { FY } 1976}{\text { Cong. Rev. }}$ Cong: Rev. FY77 FY78 FY79 FY80 FY81 Completion

PROJECT TOTAL

Operating expenses

Capital equipment

Computers

Other equipment

Plant construction

Pass-through funding

Joint funding
TOTAL

Joint funding
TOTAL
5.3

0.7

0.8

$\begin{array}{lll}0.8 & 16.5 & 2.0\end{array}$
0.8
8. 9
4.8
4. 5
5.9
5.9
18. 5 FY 85
0.2
8.5
3.0
2.0

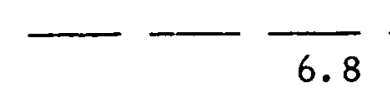

6.8

$\overline{1.8} \overline{33.9}$

9.8

6.5

5.95 .9

18. 5 FY85

Operating expenses

Capital equipment

Computers

Other equipment

Jant construction

Pass-through funding

Joint funding

SUBTOTAL

Operating expenses

Capital equipment

Computers

Other equipment

Plant construction

Pass-through funding

Joint funding

SUBTOTAL

Guidance on Pass-Through and Joint Funding:

Fire, Safety, and Other Requirements: 


\section{Sub-Program Unit: Solar Thermal}

\section{Program Element Index Number and Title: V-A-3 Solar Total Energy Systems}

Program Element Objective: To demonstrate commercial viability of providing for electric power and heating/cooling requirements of urban and rural communities, institutional/industrial load centers and military bases.

Program Element Justification: Since there are few fundamental technical limitations, substantial commercial utilization requires economic feasibility and realiability demonstrations.

Program Element Strateqy: Development of hardware through industrial contracts with program planning, mission and systems analysis contributed by ERDA. As project matures, power utilities-are expected to increase their involvement and financial support. Description of Task and Approach: This element is currently in process with completion Two (2) subsequent pilot plant developinent efforts are planned with $200 \mathrm{KWe}$ and $2 \mathrm{Ml}$ th capabilities. Two plants are required to provide different load splitting (electric versus thermal energy). Two demonstration plants of 5-10MWe and 50-200MWth capacities will follow to verify technical, operational and economic feasibility and to establish basis for commercial plants by 1990 .

Major Results and Key Decision Dates:

Decision to build 200KWe. 2MIth Pilet Plant (system \#1) 1975 Operational 1981 Decision to build 200KWe, 2MWth Pilot Plant (system \#2) 1976 Operational 1981 Decision to build 5-10MWe, 100-200MWth demonstration plant (Sys. \#1) 1979 Operational 1985

Decision to build 5-10MWe, 50MWth demonstration plant Program Element Funding (1977 dollars): $\quad$ (Sys. \#2) 1980 .Operational 1986

\begin{tabular}{|c|c|c|c|c|c|c|c|c|c|c|c|}
\hline & Est. & FY & 1976 & $\begin{array}{l}\text { Transi } \\
\text { Peri }\end{array}$ & $\begin{array}{l}\text { tion } \\
\text { od }\end{array}$ & & & & & & Through \\
\hline & FY75 & Cong. & Rev. & Cong. & Rev. & FY77 & FY78 & FY79 & FY80 & FY81 & \\
\hline Operating Expenses & 2.3 & $\vdots$ & 5.9 & & 1.3 & 12.0 & 15.4 & 18.2 & 20.1 & 19.4 & 13.0 \\
\hline Capital Equipment & & & & & & 0.5 & 2.0 & 3.3 & .9 .1 & 12.7 & 27.0 \\
\hline Computers & & & . & & & & . & & & & \\
\hline Other Equipinent & & & & & & & & V & & & \\
\hline Plant Construction & & & & & & 2.8 & 4.4 & 9.8 & 14.6 & $13.3^{2}$ & 60.0 \\
\hline $\begin{array}{l}\text { Pass-Through Funding } \\
\text { joint Funding }\end{array}$ & & & & : & & & & & & & $130 *$ \\
\hline TOTAL & 2.3 & & 5.9 & & 1.3 & 15.3 & 21.8 & 31.3 & 43.8 & 46.0 & 100.0 \\
\hline
\end{tabular}

*Expected Utility contribution to demonstration plants 


\section{SOLAR ELECTRIC APPLICATIONS PROGRAM UNIT \\ PROGRAM ELEMENT SUMMARY SHEET}

Subprogram. Solar Thermal - V-A.

Project Index Number. V-A-3.

Project Title. Solar Total Energy Systems.

Project Objectives. To provide a.full system capability for total energy systems for the production of electric, heating and cooling power for urban and rural communities, industrial load centers and military bases in support of the overall national energy program and to demonstrate commercial viability by the late $1980 \mathrm{~s}$. Project Justification. Although there are no fundamental technical limitations that would prevent substantial applications of solar thermal energy systems, the relatively higher capital investments estimated for solar power systems as compared to the investments for utilizing fossil or nuclear fuels requires that the economic feasibility be demonstrated before private capital sources would undertake the large long-term capital commitments.

Project Strategy. The major hardware developments will be funded by ERDA through contracts to industry with increasing support from the power utilities as the project matures. The program management will rest in ERDA with program planning, mission and system analys is support from the Aerospace Corporation (an FCRC) and the day by day project direction by the ERDA Sandia Laboratories at Albuquerque. Description of Task and Approach. The project was initiated by AEC in July 1972 by funding of Sandia Laboratories, Albuquerque. Phase I, background studies; Phase II, preliminary system design, analysis and economic evaluations; and Phase III, exploratory development including a collector test bed, computer simulation program, and distributed trough type collector tests have been completed. Phase IV, a 2-year effort started in July 1974, is to test and evaluate the components and to assemble a test bed model of the baseline system. Phase $V$, which ștarts in. July 1975, is the operational phase of the test bed model and is intended to validate the computer simulation developed in Phase III.

Subsequent efforts are divided into two system development efforts: \#1 system is -directed at providing the total energy needs for military bases while \#2 system is directed at providing the total energy needs for institutions, communities and industrial complexes. \#1 system will generally lead \#2 system development schedule by 1 year. Contracts to industry will be initiated in 1976 for the design and 
subsequent construction of Pilot Plants of apprlximately 200 KWe and 2 . MWth to be operational in 1979. for \#1 system and 1980 for \#2 system. Second generation pilot plants of similar capacities. will be designed and fabricated with operation planned in 1981 and 1982. The performance and economic viability of these pilot plants will be evaluated and projected to larger demonstration and commercial size plants. The close participation of industry throughout these efforts will assure an orderly transition from development phases into commercial operations for these systems. The design of demonstration plants of 5-10 MWe and 50-200 MWth capacities are to be initiated in 1980-1981 with plant operations anticipated for 1985-1986. These demonstration plants will verify the technical, operational and economic feasibility of the Solar Total Energy Systems and evolve directly to the establishment of commercially operating plants by early 1980s. The successful demonstration plants are expected to continue to operate beyond the performance demonstration period in commercial mode. It is anticipated that the demonstration plants will be funded by $50 \%$ or more by private capital and the commercial plants entirely with private capital. However, the initial generation of commercial solar total energy plants may require government funding assistance in the way of low interest rate loans. Major Results and Key Decision Dates. The performance evaluation of the pilot plants in 1980 and 1381 will provide the necessary data for the key decision to proceed with the high expense of fabrication and construction of the demonstration plants. Preliminary and detail designs for the demonstration plants will start in 1979 and 1980 but the long term, high cost commitment for fabrication and construction of the demonstration plants should be made to facilitate 1981 and 1982 contract awards. 
Task Funding (1977 dollars): V-A-3a \#1 SYSTEM, SOLAR TOTAL ENERGY SYSTEMS Transition

EY75 Cong: Rev. Cong. Rev. EY77 FY78 EY79 EY80 FY81 Completion

Subprioject \# al

COMPONENT T TESTING

Operating expenses

1.7

$0.42 .4 \quad 2.6$

2.3

$1.7 \quad 1.7$

Capital equipment

Cọmputers

Other equipment

Plant construction

Pass-through funding

Joint furding

SUBTOTAL

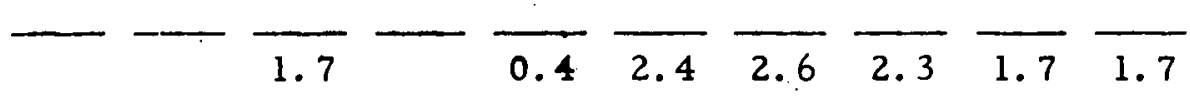

subproject \#a2

\section{BENCH MODEL}

Operating expenses

0.7

0.1

$2.5 \quad 3.1$

2.9

$2.5 \quad 2.5$

Capital equipment

Computers

Other equipment

Plant construction

Pass-through funding

Joint funding

SUBTOTAL

$-\frac{.}{0.7}$
KWe, 2 MWth)
0.3

Operating expenses

Capital equipment

Computers

Other equipment

Plant construction

Pass-through funding

Joint funding

SUBTOTAL

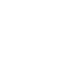

0.1

0.30.

0.51 .

0.7 .

0.7

0.7

1.7 FY85

Guidance on Pass - Through and Joint Funding:

\section{Fire, Safety, and Other Reguirements:}


Task Funding (1977 dollars): V-A-3a \#1 SYSTEM, SOLAR TOTAL ENERGY SYSTEMS

Transition

(Continued)

EY 1976 Period

Through

FY75 Cong. Rev. Cong. Rev. FY77 FY78 FY79 FY80 FY81 Completion

\section{Subptoject \#a4}

\section{ND GENERATION PILOT PLANT}

Operating expenses

$\begin{array}{llllll}0.5 & 0.6 & 1.0 & 0.5 & 1.4 & \text { FY } 85\end{array}$

Capital equipment

$\begin{array}{llllll}1.0 & 2.0 & 2.0 & 2.0 & \text { FY } 83\end{array}$

Computers

Other equipment

Plant construction

$1.0 \quad 2.8 \quad 3.5 \quad 3.6$

Pass-through funding

Joint funding

SUBTOTAL
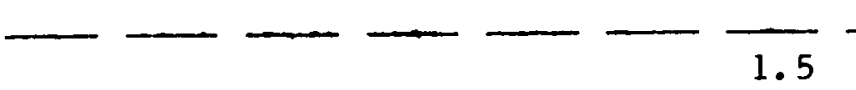

$\overline{4.4} \overline{6.5} \overline{6.1} \overline{3.4 \text { FY } 85}$

\section{Subproject Ha5}

DEMONSTRATION PLANT (5-10 MWe, 100-200 MWth)

Operating expenses

$0.8 \quad 2.4 \quad 2.6 \quad 6-10$

Capital equipment

$5.6 \quad 13-20$

Computers

Other equipment

Plant construction

Pass-through funding

Joint funding

SUBTOTAL
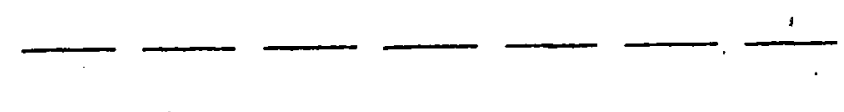

0.8

2.4

$14.2 \quad 40-80$ FY85

Operating expenses

Capital equipment

$$
\text { Computers }
$$

Othe's equipment

Plant construction

Pass-through funding

Joint funding

SUBTOTAL

Guidance on Pass - Through and Joint Funding:

Fire, Safety, and Other Requirements: 
Task Funding (1977 dollars): V-A-3b \#2 TOTAL ENERGY SYSTEM

Transition

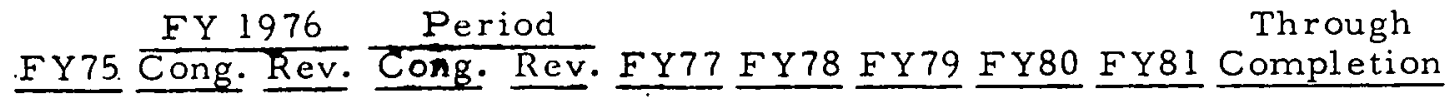

Subproject \#bl

COMPONENT TESTING

Operating expenses.

1.7

$0.4 \quad 2.4 \quad 3.1$

2.9

$2.5 \quad 2.5$

Capital equipment

Computers

Other equipment

Plant construction

Pass-through funding

Joint funding

SUBTOTAL

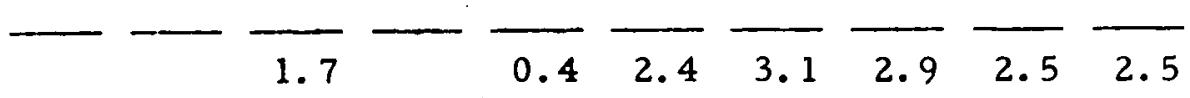

Subproject \#b2

BENCH MODEL

Operating expenses

0.7

$0.1 \quad 1.4 \quad 3.6 \quad 3.8 \quad 3.8$

Capital equipment

Computers

Other equipment

Plant construction

Pass-through funding

Joint funding

SUBTOTAL

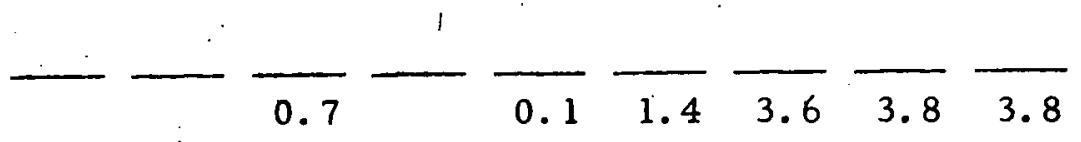

Subproject \#b3

PILOT PLANT

Operating expenses

0.3

$0.1 \quad 1.8$

0.4

$0.5 \quad 1.0 \quad 1.0$

$0.7 \mathrm{FY}$

Capital equipment

$\begin{array}{lllll}1.0 & 0.7 & 3.7 & 3.2 & 1.0\end{array}$

Computers

Dther equipment

Plant construction

$\begin{array}{lllll}1.4 & 1.8 & 3.0 & 3.0 & 1.0\end{array}$

Pass-through funding

Joint funding

SUBTOTAL

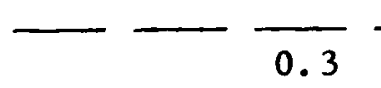

0.3

$\overline{0.1} \overline{3.2} \overline{3.2}$

4.2

$7.7 \quad 5.2$

1. 7 FY82

Guidance on Pass - Through and Joint Funding:

Fire, Safety, and Other Requirements: 
Task:Funding (1977 dollars): V-A-3b \#2 SOLAR TOTAL ENERGY SYSTEM (Continued)

Transition

FY75 EOng. Rev. Cong. Rev. EY77 FY78 FY79 EY80 EY81 Completion

Subprojece \#b4

2ND.GEN. PILOT PLANT

Operating expenses

$\begin{array}{llll}1.2 & 0.4 & 0.4 & 3.0\end{array}$

Capital equipmont

$0.9 \quad 0.9 \quad 6.2$

Computers

Other equipment

Plant construction

$\begin{array}{llll}1.0 & 3.3 & 3.3 & 3.3\end{array}$

Pass-through funding

Joint funding SÜBTOTAL
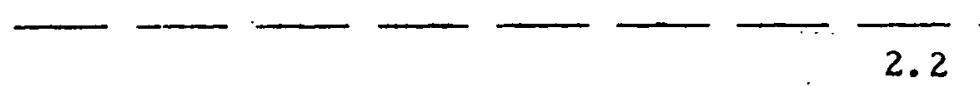

4.6

$4.6 \quad 12.5$ FY84

Subproject \#b5

DEMONSTRATION PLANT

Operating expenses

Capital equipment

$0.8 \quad 4.2 \quad 10$

Computers

Other equipment

Plant construction

$30-60$

Pass-through funding

Joint funding

SUUBTOTAL
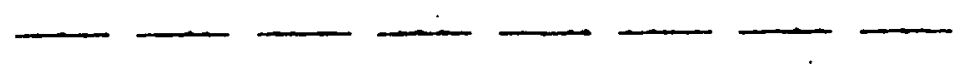

0.8

4. $260-120$ FY 86

Subproject \#6

PROJECT MANAGEMENT \& ENG. SUPPORT (Sandia Albuquerque)

$\begin{array}{llllllllll}\text { Operating expenses } & 0.5 & 0.1 & 1.2 & 1.8 & 2.5 & 3.3 & 3.3 & 5.6\end{array}$

Capitál equipment

Computers

Other equipment

Plant: construction

Pasg-through funding

Joint funding

SUBTOTAL

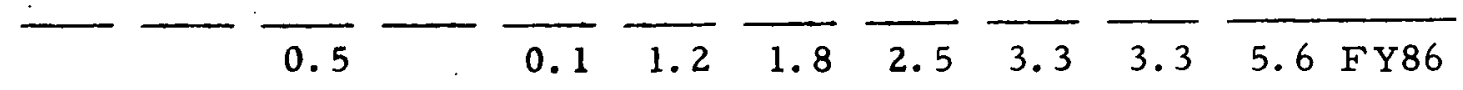

Guidance on Pass-Through and Joint Funding:

(1) Not included in run-out totals.

Eire, Safety, and Other Requirements: 
Task Funding (1977 dollars): V-A-3 SOLAR TOTAL ENERGY SYSTEMS

Transition

FY 1976 Period Through

FY75 Cong. Rev. Cong. Rev. FY77 FY78 EY79 EY80 EY81 Completion

PROJECT TOTAL

Operating expenses

5.9

$\begin{array}{lllllll}1.3 & 12.0 & 15.4 & 18.2 & 20.1 & 19.4 & 11-13\end{array}$

Capital equipment

$$
\begin{array}{llllll}
0.5 & 2.0 & 3.3 & 9.1 & 12.7 & 24-27
\end{array}
$$

Computers

Other equipment

Plant construction

$\begin{array}{llllll}2.8 & 4.4 & 9.8 & 14.6 & 13.9 & 25-60\end{array}$

Pass-through funding

Joint funding

TOTAL

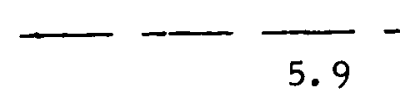

5.9

1.315 .3

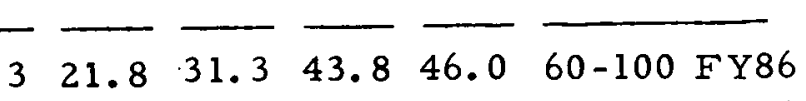

\section{Operating expenses}

Capital equipment

Computers

Other equipment

Plant construction

Pass-through funding

Joint funding

SUBTOTAL

Operating expenses

Capital equipment

Computers

Other equipment

Plant construction

Passithrough funding

Joint funding

SUBTOTAL

Guidance on Pass-Through and Joint Funding:

Fire, Safety, and Other Requirements: 
SOLAR ELECTRIC APPLICATIONS PROGRAM UNIT

PROGRAM ELEMENT SUMMARY SHEET

Sub-Program Unit: Solar Thermal

Program E.lement Index Number and Title: V-A-4 Distributed Collector Power Plant

Program Element Objectives: To develop and demonstrate commerctal viability of system to provide widespread production of supplemental electric power and stimulate electric utilities to build plants for load following or intermediate load electric power requifrements.

Program Element Justification: In order to benefit from collector efficiency improvement studies planned and in progress, evaluation of power generation capability is required. This system may offer a viable alternative to central receiver system $(V-A-1)$

Program Element Strategy: The collector developments and other components wi 11 be Eested at the solar thermal test facility $(V-A-2)$. After evaluation of results, a lovile pilot plant will be constructed.

Description of Task and Approach: The collectors and other components will be thoroughty tested and economic evaluations made to verify viability of concept. After evaluation of results, a loMWe pilot plant will be constructed. A second generation plant will be designed and constructed to employ new or alternate concepts. Success of these plants is expected to result in a 100Mle demonstration plant being completed by 1987 with utilities involved in this effort.

Major Results and Key Decision Dates:

Decision to butld bench model

Decision to build Torille pilot plant

Decision to build 100MWe demonstration plants
In Work Operational 1977

$1977^{\circ}$ Operationat 1982

1982 Operational 1987

Program Element Funding (1977 dol lars):

\begin{tabular}{|c|c|c|c|c|c|c|c|c|c|c|c|}
\hline r. & Est. & FY & $\frac{1976}{80}$ & $\begin{array}{l}\text { Transi } \\
\text { Peri } \\
\end{array}$ & tion & & & & & & Through \\
\hline & $\underline{F Y 75}$ & Cong. & & Cong. & Rev. & FY77 & FY78 & FY79 & FY80 & FY81 & \\
\hline Operating Expenses & 0.1 & & & & & 5.5 & 5.8 & 9.6 & 8.0 & 9.0 & 14.0 \\
\hline Capital Equipment & & & & & & & 1.9 & 9.0 & 7.0 & 12.6 & 3.0 \\
\hline Computers & & & & & & & & & & & \\
\hline Other Equipment & & & & & & & & & & & \\
\hline Plant Construction & & & & . & & & 6.0 & 4.0 & 10.0 & 6.6 & 2.0 \\
\hline $\begin{array}{l}\text { Pass-Throagh Funding } \\
\text { Joint Funding }\end{array}$ & & & & & & & . & & & & $160.0 *$ \\
\hline TOTAL & 0.1 & & & & & 5.5 & 13.7 & 22.6 & 25.0 & 28.2 & 19.0 \\
\hline
\end{tabular}

*Anticipated Industrial Involvement in demonstration plants (Not included in total). 


\section{SOLAR ELECTRIC APPLICATIONS PROGRAM UNIT \\ PROGRAM ELEMENT SUMMARY' SHEET}

Subprogram: Solar Thermal-V-A

Project Number: V-A-4

Project Title: Distributed Collector Power Plant

Project Objectives: To provide a full system capability for the widespread production of supplementary electric power in the $1980^{\prime}$ s to meet electric utility requirements for load-following or intermediate load electric power generating systems economically in support of the overall national energy program.

Project Justificiation: Although initial analysis indicates that the central receiver concept $(V-A-1)$ promises to provide the greatest efficiency for conversion of solar energy into electric power, it is ossential to consider and analyze the alternate concept of distributed collector power plants. A great deal of technology has been generated for heating and cooling systems employing distributed collectors which should be evaluated further for potential adaptation to electric power generation yotems. It is essential to demonstrate collector efficiency increases from about $60 \%$ to near $90 \%$ for continuing project justification.

Project Strategy: The major hardwaro evaluation and application development will be lunded by ERDA through contracts to industry with increasing support anticipated from the power utilities as the project feasibility is developed and established. The program management will rest in ERDA with program planning mission and system analysis support from The Aerospace Corporation (an FCRC). The day by day project direction will be designated by ERDA after suitable collector efficiencies have been established.

Description of Task and Approach: Earlier misoion and system analysis by The Aerospace Corporation indicated that the distributed collectur efficiencies were too low compared to the central receiver collector concept to be economically or technically competitive. The first phase will include a re-evaluation and component testing of existing collector systems to determine the probability of increasing the collector efficiencies and improving the quality of thermal conversion to acceptable values. This effort will also include preliminary designs for a $10 \mathrm{MWe}$ pilot plant which will include estimates for the cost of generating electric power. Further effort must be based on the positive results from the above efforts. Assuming positive results, detail designs and construction of the $10 \mathrm{MWe}$ pilot plant will be initiated. It is anticipated that a second generation pilot plant will be designed and constructed to employ new or alternate concepts. These pilot plants are expected to be operational in 1980 and 1982 , respectively. The performance and economic viability of these pilot plants will be projected to a Jarger demonstration plant. The close participation of the power utilities in the pilot plant development and operations will contribute to the design and construction of a $100 \mathrm{MWe}$ demonstration plant.

Major Results and Key Decision Dates: The mission and system analysis, together with selected component testing and evaluation, is required in late 1977 or early 1978 to establish collector efficiency increases sufficient to justify project continuation. Pilot plant operational evaluation in 1981 is required to justify the design and construction of the demonstration plant. 
Task Funding (1977 dollars): V-A-4 DISTRIBUTED COLLECTOR POWER PLANT

Transition

FY75 $\frac{\text { FY } 1976}{\text { Cong. Rev. }}$ Cong. Rev. FY77 FY78 FY79 FY80 FY81 Completion

Subproject \# 1

COMPONENT TESTS

Operating expenses

$2.4 \quad 3.6 \quad 4.2 \quad 2.8 \quad 1.7$

Capital equipment

Computers

Other equipment

Plant construction

Pass-through funding

Joint funding

SUBTOTAL

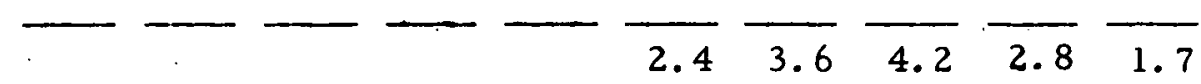

Subproject \#2

PILOT PLANT

Operating expenses

Capital equipment

$\begin{array}{rrrrrr}2.6 & 1.0 & 1.3 & 2.0 & 2.4 & 7.6 \\ & 1.9 & 9.0 & 5.0 & 5.0 & --\end{array}$

Computers

Other equipment

Plant construction

$6.0 \quad 4.0 \quad 4.0 \quad 1.0$

Pass-through funding

Joint funding

SUBTOTAL
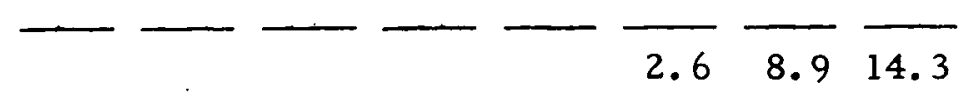

$\overline{11.0}$

8.4

7.6 FY85

Subproject \# 3

2ND GEN. PILOT PLANT

Operating expenses

Capital equipment

$$
\begin{array}{llll}
2.1 & 1.0 & 1.0 & 4.3 \\
& 2.0 & 7.6 & 3.0
\end{array}
$$

\section{Computers}

Other equipment

Plant construction

Pas 3-through funding

Joint funding

SUBTOTAL.
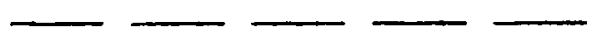

2.1

$8.4 \quad 14.2 \quad 9.3 \quad$ FY 85

Guidance on Pass-Through and Joint Funding:

Fire, Safety, and Other Requirements: 
Task Funding (1977 dollars): V-A-4 DISTRIBUTED COLLECTOR POWER PLANT

Subproject \#4

\section{DEMONSTRATION PLANT}

Operating expenses

1.7

Capital equipment

\section{Computers}

Othet equipment

Plant construction

Pass-through funding

Joint funding SUBTOTAL

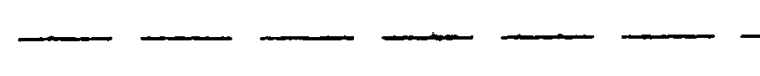

$1.7 \overline{90-160 \text { FY } 85^{(1)}}$

\section{Subproject \#5}

PROJECT MANAGEMENT \& ENGINEERING SUPPORT (ERDA Lab)

Operating expenses

$0.5 \quad 1.2 \quad 2.0$

$2.2 \quad 2.2 \quad 1.7$

Capital equipment

Computers

Other equipment

Plant construction

Pass-through funding

Joint funding SÜBTTAL

\section{L}

PROJECT TOTAL

Opérating expenses

$\begin{array}{rrrrrr}5.5 & 5.8 & 9.6 & 8.0 & 9.0 & 14.0 \\ & 1.9 & 9.0 & 7.0 & 12.6 & 3.0\end{array}$

Capital equipment

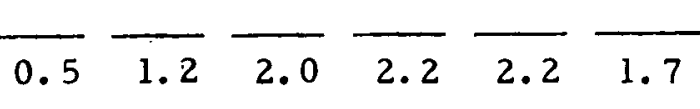

\section{Computers}

Other equipment

Plant construction

Fass-through funding

Joint funding

TOTAL

$\begin{array}{llllll}5.5 & 13.7 & 22.6 & 25.0 & 28.2 & 19.0 \quad \text { FY } 85\end{array}$

Guidance on Pass - Through and Joint Funding:

(1) Not included in Run-out Totals

Fire, Safety, and Other Requirements: 


\section{SOLAR ELECTRIC APPLICATIONS PROGRAM UNIT}

PROGRAM ELEMENT SUMMARY SHEET

\section{Sub-Program Unit: Solar Thermal}

Program Element Index Number and Title: V-A-5 Hybrid Solar Thermal Systems

Program Element Objective: To maximize utflization of complementary solar thermal systems in conjunction with fossil fuel and other energy systems.

Program Element Justification: Utilization of solar thermal energy developments with other energy systems will result in fossil fuel usage reduction and capitalization of hardware development efforts of solar thermal projects.

Program Element Strategy: Determine possible hybrid systems and select viable economic/energy conserving systems for pilot plant testing.

Description of Task and Approach: Mission analys is to identify potentially efficfent hybrid systems and to identify market potential and demand. Component testing and development of three promising systems. Encourage commercial application through pilot plant operation.

Major Results and Key Decision Dates:

Decision on component hardware

Test Facility complete and component testing begin

Decision to build initial pitotiplant :

Initlal pilot plant in operation

1977

Third pilot plant in operation

Program Element Funding (1977 dollars):

Est. FY $1976 \quad \begin{aligned} & \text { Transition } \\ & \text { Period }\end{aligned}$
FY75. Cong Rev Cong Rev FY77 FY78 FY79 FY80 FY81 Completion

Operating Expenses

Capital Equipment

Computers

Other Equipment

Plant Construction

Pass-Through Funding

Joint Funding

\subsection{4 .1}

$\begin{array}{lll}6.3 & 9.2 & 10.8\end{array}$

28.0

$\begin{array}{lll}3.0 & 11.0 & 19.0\end{array}$

27.0

$\begin{array}{lll}4.0 & 8.0 \quad 12.0\end{array}$

17.0

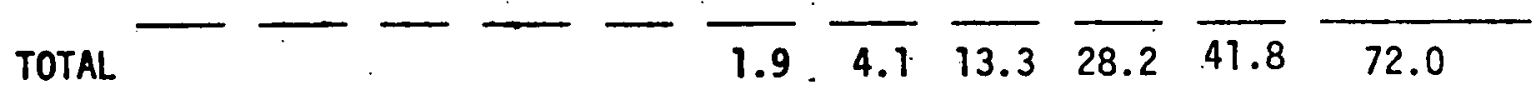


Program Element Index Number and Tit]: Solar Thermal

Project Index Number and Title: V-A-5 Hybrid Solar Thermal System

Project Objective: To utilize some of the solar thermal systems to complement energy progress. Both solar and other new energy developrients as well as conventional fossil fuel systems.

Project Justification: To capitalize on the solar thermal energy developments so as to maximize the rapid development and implementation of plants minimizing the use of fossil fuels:

Profect Strategy: Review the possible solar thermal hybrid systems (i. e. fossil, fuel, geothermal, photovoltaic, etc.). Identify promising efficient combinations. Conduct component research and pilot plant tests.

Description of Task and Approach: Hybrid mission analysis to identify potentially efficient hybrid systems, identify potential margin and demand. Conduct component test and pilot plant devilopment for the three most promising.

Major Results and Key Decision and Dates:

Oct. 76 - component hardware contracts initiated.

Oct. 77- Test facility complete, component tests start.

Oct. 77- Starts design of first pilot plant.

Oct. 78-Start construction of first pilot plant.

Oct. 79- Start construction of second pilot plant.

Oct. 80- Start construction of third pilot plant

Oct. 81 - first hybrid plant in operation. (pilot plant)

Oct. 82 - second hybrid plant in operation. (pilot plant)

Oct. 83- Third hybrid pilot plant in operation

Task Funding (1977 dollars):

FY75 $\frac{\text { FY 1976 }}{\text { Cong: Rev. }} \begin{gathered}\begin{array}{c}\text { Transition } \\ \text { Period }\end{array} \\ \text { Cong: Rev. EY77. FY78 FY79 FY80 FY81 Completion }\end{gathered}$

Operating expenses

Capital equipment

Computers $(1)$ $\begin{array}{lllllll}1.9 & 4.1 & 6.3 & 9.2 & 10.8 & 28.0\end{array}$

$3.0 \quad 11.0 \quad 19.0 \quad 27.0$

Other equipmient

Plant construction (2)

Pass -through funding (3)

Joint funding (4)

(4) (3)

$\begin{array}{llll}4.0 & 8.0 & 12.0 & 17.0\end{array}$

TOTAL

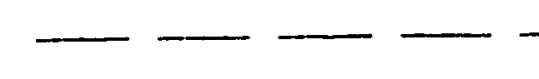

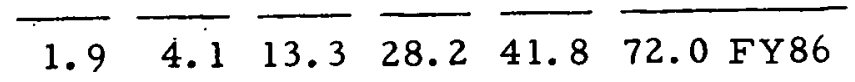

Fire, Safety, and Other Requirements:

Prerequistte Project Index Number(s) and Title(s):

(1) Include a listing of major computers $(\$ 500,000$ or over) and associate costs by year

(2) Include a listing of projects with total estimated costs of $\$ 5$ million or more and associated costs by year

(3) Include listing of pass-through funding from other agencies by agency and year

(4) Include listing of joint funding from industry by industry and year 
Task Funding (1977 dollars): V-A-5 HYBRID SOLAR THERMAL SYSTEMS

Transition

FY75 $\frac{\text { FY } 1976}{\text { Cong. Rev. }}$ Cong. Rev. FY77 FY78 EY79 EY80 EY81 Completion

Subproject \# 1

COMPONENT TESTING

Operating experises

$$
\begin{array}{lllll}
1.7 & 2.4 & 2.4 & 2.4 & 2.4
\end{array}
$$

Capital equipment

Computers

Other equipment

Plant construction

Pass-through funding

Joint funding

SUBTOTAL
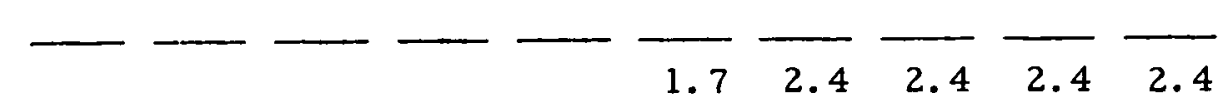

Subproject \#2

\# 1 SYSTEM PILOT PLANT

Operating expenses

$\begin{array}{lllll}1.3 & 1.4 & 1.6 & 1.7 & 7.2\end{array}$

Capital equipment

$\begin{array}{llll}3.0 & 8.0 & 8.0 & 1.0\end{array}$

Computers.

Other equipment

Plant construction

$\begin{array}{llll}4.0 & 4.0 & 4.0 & 1.0\end{array}$

Pass-through funding

Joint funding

SUBTOTAL
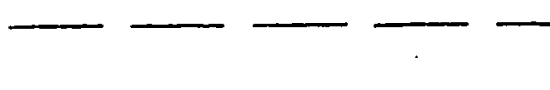

1.

8.4

$13.6 \quad 13.7$

9.2 FY 85

Subproject \#3

\section{\#2 SYSTEM PILOT PLANT}

Operating expenses

Capital equipment

$\begin{array}{llll}1.3 & 1.4 & 1.7 & 6.8 \\ & 3.0 & 8.0 & 9.0\end{array}$

Computers

Othe $r$ equipment

Plant construction

$4.0 \quad 4.0 \quad 6.0$

Pass-through funding

Joint funding

SUBTOTAL

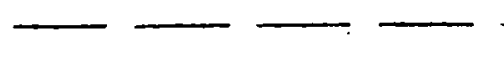

$\begin{array}{llllll}1.3 & 8.4 & 13.7 & 21.8 & \text { FY } 86\end{array}$

Guidance on Pass - Through and Joint Funding:

Fire, Safety, and Other Requirements: 
Task Funding (1977 dollars): V-A-5 HYBRID SOLAR THERMAL SYSTEMS (Continued) Transition

FY75 Cong. Rev. Cong. Rev. EY77 FY78 EY79 EY80 EY81 Completion

Subproject \#4

\#3 SYSTEM PILOT PLANT

Operating expenses

$1.3 \quad 1.4 \quad 7.4$

Capital equipment

3.0. 17.0

Computers

Other equipment

Plant construction

$.4 .0 \quad 10.0$

Pass-through funding

Joint funding

SUBTOTAL
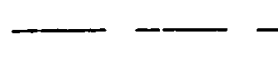

Subproject \#5

PROJECT MANAGEMENT \& ENGINEERING SUPPORT

Operating expenses

0.2

Capital equipment

\section{Computers}

Pther equipment
Cant construction

Pass-through funding.

Toint funding

SUBTOTAL
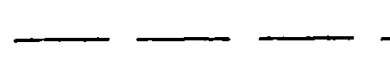

$5.2 \overline{0.4} \overline{1.2} \overline{2.5} \overline{3.6} \quad \overline{6.5} \mathrm{FY} 87$

PROJECT TOTAL

Operating expenses

$\begin{array}{llllll}1.9 & 4.1 & 6.3 & 9.2 & 10.8 & 28.0\end{array}$

Capital equipment

$3.0 \quad 11.0 \quad 19.0 \quad 27.0$

Computers

Other equipment

Plant construction

$4.0 \quad 8.0 \cdot 12.0 \quad 17.0$

Pass-through funding

Joint funding

TOTAL
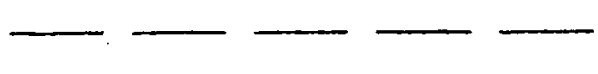

1.9

$\overline{4.1} \overline{13.3} \overline{28.2} \overline{41.8} \overline{72.0 \mathrm{FY} 86}$

Guidance on Pass - Through and Joint Funding:

re, Safety, and Other Requirements: 


\section{SOLAR ELECTRIC APPLICATIONS PROGRAM UNIT}

PROGRAM ELEMENT SUMMARY SHEET

Sub-Program Untt: Solar Thermal

Program Element Index Number and Title: V-A-6 Research and Development

Program Element Objective: To provide the R\&D efforts required to improve the systems technical performance over the development years and R\&D efforts required to reduce system cost and to develop and encourage adoption of required mass production techniques for system and components.

Program Element Justification: Electric utilities will not adopt the use of solar thermal power conversion plants until demonstration that electrical power can be provided at competitive rates. Continued performance improvements are required to meet that objective.

Program Element Strategy: The research and development effort will address areas identified by the mission/system analysis studies ( $V-A-7)$ that offer the greatest potential benefit to the program and to the various projects. As technical breakthroughs are made, new mission analysis studies will again estabish R\&D priorities.

Description of Task and Approach: R\&D efforts will be assigned to increasing the performance and reducing costs of Central Receiver Power Plants. It will also include surface coatings high temperature materials testing of various types of distributed collectors, examination of Brayton Cycle Systems, etc.

Major Results and Key Decision and Dates: There are no major results or key decision dates. However, it appears that if the "distributed collector electrical power plant is to be a contender with the central receiver power plants an increase in collection efficiency of about twenty percent will be required. Other areas will be identified as the analysis progresses

Program Element Funding (1977 dollars):

Est. FY 1976 Transition

FY75 Cong Rev Cong Rev FY77 FY78 FY79 FY80 FY81 Completion

Operating Expenses $\quad 1.9 \quad 6.0$

Capital Equipment

Computers

Other Equipment

Plant Construction

Pass-Throuyh Funding

Joint Funding

$$
\text { TOTAL } \overline{1.9}=\overline{6.0}=\overline{1.5} \overline{10.0} \cdot \overline{15.0} \overline{15.0} \overline{15.0} \overline{10.0} \overline{40.0}
$$


Program Element Index Number and Title: Solar Thermal

Project Index Number and Title: V-A-6 Research and Technology

Project Objective: To provide the substantial R\&T efforts to improve the systems technical performance over the development years and any additional $R \& D$ efforts required to reduce system cost and to develop and encourage adoption of the required mass production techniques.

Project Justification: Electric utilities will not adopt the use of solar thermal power conversion plants until demonstration that electrical power can be provided at competitive rates, continued performance improvements are required to meet that objective. Research and technology effort will be directed at those areas with greatest payoff.

Project Strategy: The research and technology effort will address those areas identified by the mission/system analysis studies (V-A-7) that offer the greatest potential benefit to the program and to the various projects. As tentative break-throughs are made new mission analysis studies will again establish R \&D priorities. Description of Task and Approach: $R \& D$ efforts will be assigned to increase the performance and reduce costs of central receiver power plants. It will also include surface coating, high temperature material, testing of various types of distributed collectors, examination of Brayton cycle systerns; etc.

Major Results and Key Decision and Dates: There are no major results of key decision dates. However, it appears that if the distributed collector electrical power plant is to be a contender with the central receiver power plants, an increase in collection efficiency of about twenty percent will be required for the distributed collector. Other areas will be highlighted for R\&D as the analysis progresses.

Task Funding (1977 dollars):

$$
\text { EY75 Cong. Rev. } \frac{\text { FY } 1976}{\text { Cong. Rev. FY77 FY78 FY79 FY80 FY81 }} \begin{gathered}
\text { Through } \\
\text { Completion }
\end{gathered}
$$

Operating Expenses

$\begin{array}{lllllllll}6.0 & 1.5 & 10 & 15 & 15 & 15 & 10 & 40 \text { FY } & \text { SE }\end{array}$

Cap1tal Equipment

Computers (1)

Other Equipment

Plant Construction (2)

Plant Construction

Joint Funding (4)

'I'U'AL

$-\frac{10}{6.0}-$
Other Requirements:

Fire, Safety, and Other Requirements:

Prerequisite Project Index Number(s) and Title(s):

(1) Include a listing of major computers ( $\$ 500,000$ or over) and assoctate costs by year

(2) Include a listing of projects with total estimated costs of $\$ 5$ million or more and associated costs by year

(3) Include listing of pass-through funding from other agencies by agency and year

(4) Include listing of joint funding from industry by industry and year 


\section{SOLAR ELECTRIC APPLICATIONS PROGRAM UNIT \\ PROGRAM ELEMENT SUMMARY SHEET}

Sub-Program Unit: Solar Thermal

Program Element Index Number and Title: V-A-7, Program Support

Program Element Objectives: To provide the mission system analysis and program management support to coordinate planning and to maintain perspectives of projects to the total program.

Program Element Justification: The thermal program comprises a major part of the national solar energy program and must be continuously reviewed and modified where necessary.

Program Element Strategy: Continuously maintain up to date technical data, scheduie, cost and performance parameters from industrial contractors participating in the program Utilize this. information to update the system/mission analys is thus icentifying changes to be made internal to each project. Reestablish priorities among various program projects to obtain the overall solar thermal program objectives.

Description of Task and Approach: Timely review of contractors and projects technical and schedule performance, preparation and maintaining a coordinated program plan, preparation of overall project program test plan, test facilities plan, site selection criteria, environmental impact criteria and plan, test facility and pilot plant climatic measurement plan and research.

Major Results and Key Decision and Dates: This element continues through completion of projects - FY TSO5.

Program Element Funding (1977 dollars):

Est. FY 1976 - Period

FY75 Cong Rev Cong Rev FY77 FY78 FY79. FY80 FY81 Completion

$\begin{array}{llllllllllll}\text { Operating Expenses } & 0.6 & 1.95 & 1.2 & 0.5 & 0.4 & 1.9 & 1.9 & 1.9 & 1.9 & 1.9 & 7.6\end{array}$

Capital Equipment

Computers.

Other Equipment

Plant Construction

Pass-Through Funding

Joint Funding

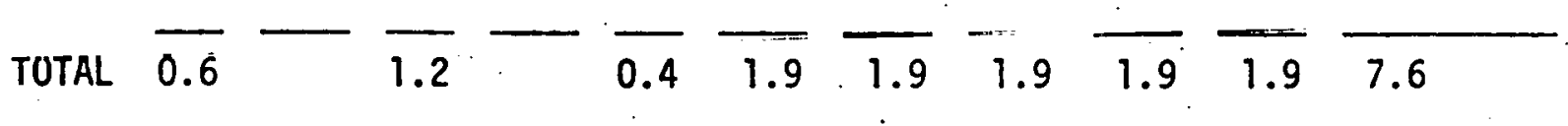


Program Element Index Number and Tit:: : Solar Thermal

Project Index Number and Title: V-A-7 Program Support

Project Objective: To provide the mission system analysis and program management support for the Solar Thermal Program that is required to provide the coordinated planning and maintain the proper perspective of project to the total program so that each individual effect is consistent with and contributes to the technical and schedule requirements of the total solar thermal program.

Project Justification: The Solar Thermal Program comprises a major part of the National Solar Energy Program which must be continuously reviewed and modified where necessary. Modifications are typically required to reflect technical achievements and uncertainties which arise within each project from within the program or from other technical program changes in the budgets available, program funding priorities, changing goals, or schedule changes occurring within individual program projects.

Project Strategy: To continuously obtain the most up to date technical data schedule, cost and performance parameters from the many industry contractors participating in the program to utilize this information to update the system/mission analysis, thus identifying changes to be made internal to each project and also to reestablish prioritie: among the various program projects to best obtain the overall solar thermal program objectives.

Description of Task and Approach: Timely review of contractors and projects technical and schedule performance, preparation and maintenance of a coordinated prograr. plan, selection criteria, environmental impact criteria and plan, test facility and pilot plant climatic measurement plan and research.

Major Results and Key Decision and Dates: The major result and key decision dates have been identified in projects $\mathrm{V}-\mathrm{A}-1, \mathrm{~V}-\mathrm{A}-2, \mathrm{~V}-\mathrm{A}-3, \mathrm{~V}-\mathrm{A}-4$ and $\mathrm{V}-\mathrm{A}-5$.

Task Funding (1977 dollars):

FY75 Cong. Rev. $\frac{\text { FY } 1976}{\text { Cong. Rev. FY77 FY78 FY79 FY80 FY8I Completion }} \begin{gathered}\text { Through } \\ \text { Period }\end{gathered}$

$\begin{array}{llllllllllllll}\text { Operating Expenses } & 0.6 & 1.95 & 1.2 & 0.5 & 0.4 & 1.9 & 1.9 & 1.9 & 1.9 & 1.9 & 7.6 & \text { FY } 85\end{array}$

Capital Equipment

Computers $(1)$

Other Equipment

Plant Construction (2)

Pass-Through Funding (3)

Joint Funding (4)

IUIAL̀

$$
\begin{aligned}
& \overline{0.6}-\frac{}{1.4 \mathrm{~b}}-\frac{0.4}{0.5}- \\
& \text { Other Requirements: } \\
& \text { ject Index Number(s) and Title(s): }
\end{aligned}
$$

(1) Include a listing of major computers $(\$ 500,000$ or over) and associate costs by year

(2) Include a listing of projects with total estimated costs of $\$ 5$ million or more and assoclated costs by year

(3) Include listing of pass-through funding from other agencies by agency and year

(4) Include listing of joint funding from industry by industry and year 
Section 3.0 consists of two alternative budgeting plans. Each budget plan is presented at two levels of funding below that of the basic plan for FY 1976 presented in Section 2.0. Each of these plans provides that the. program will be "back on schedule" by 1978 to 1979 (as nearly as possible) by increased funding for 1977, 1978, and 1979 to attempt to maintain overall program schedules and objectives. Alternative Plan \# 1 assumes the priority objectives of the Central Receiver Project, including its Test Facility, and allocates the FY 1976 funding levels of $\$ 20.9 \mathrm{M}$ in Table II and $\$ 13.2 \mathrm{M}$ in Table III reflecting this priority status of the Central Receiver Project. Alternative Plan \#2 assumes the same funding priority allocations as the Basic Plan, i.e., $\$ 29.5 \mathrm{M}$, so that each of the several projects shares in the funding levels of $\$ 20.9 \mathrm{M}$ in Table IV and $\$ 13.2 \mathrm{M}$ in Table $\mathrm{V}$ in the same proportions as for the Basic Plan funding of \$29.5M.

Alternative Plan \# 1 is recommended for use in the event of actual budget funding less than the $\$ 29.5 \mathrm{M}$ (i.e., additional funding to the Central Receiver Project, if available). Alternative Plan \#2 is included for comparison purposes only. 


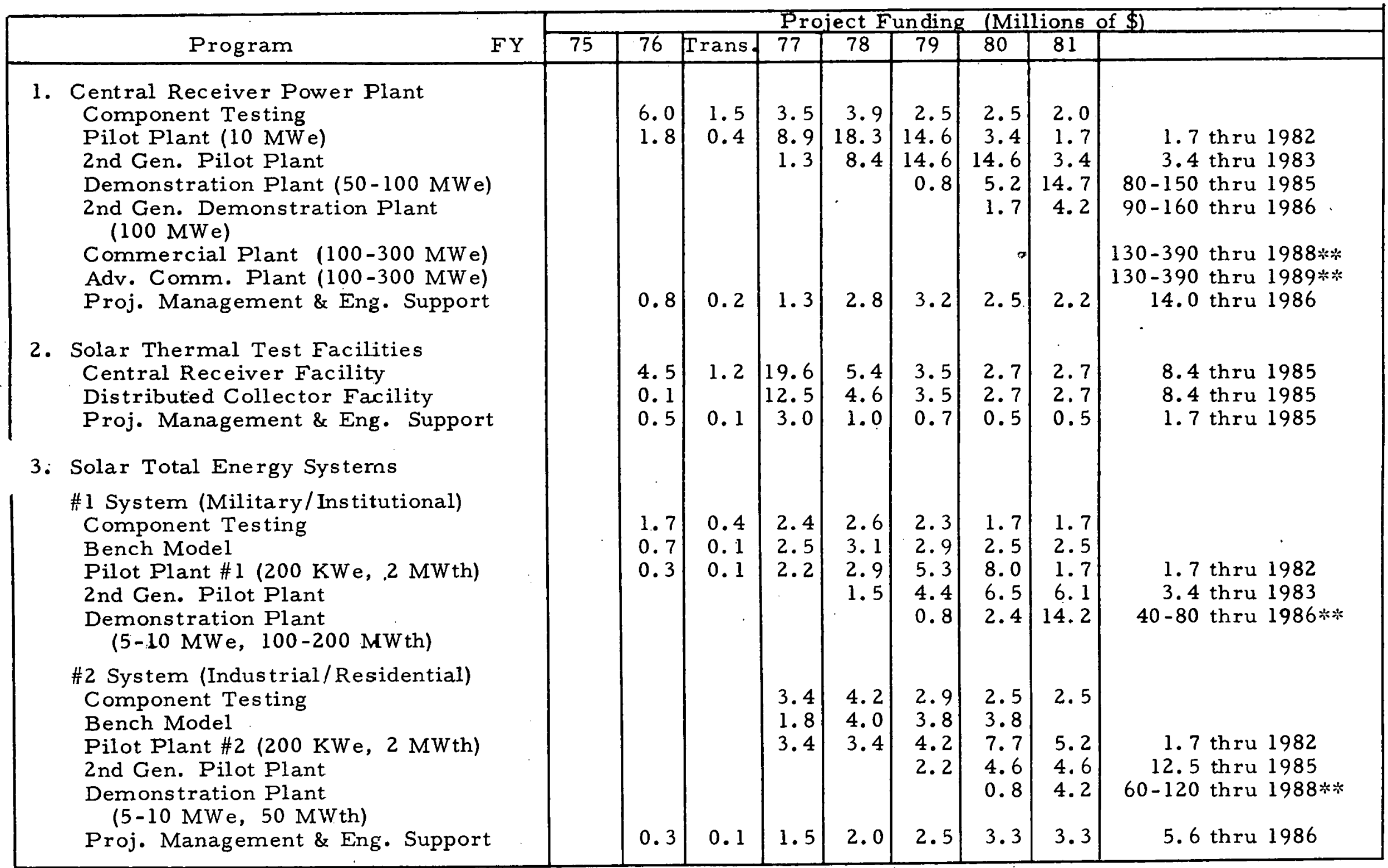


SOLAR THERMAL SUBPROGRAM

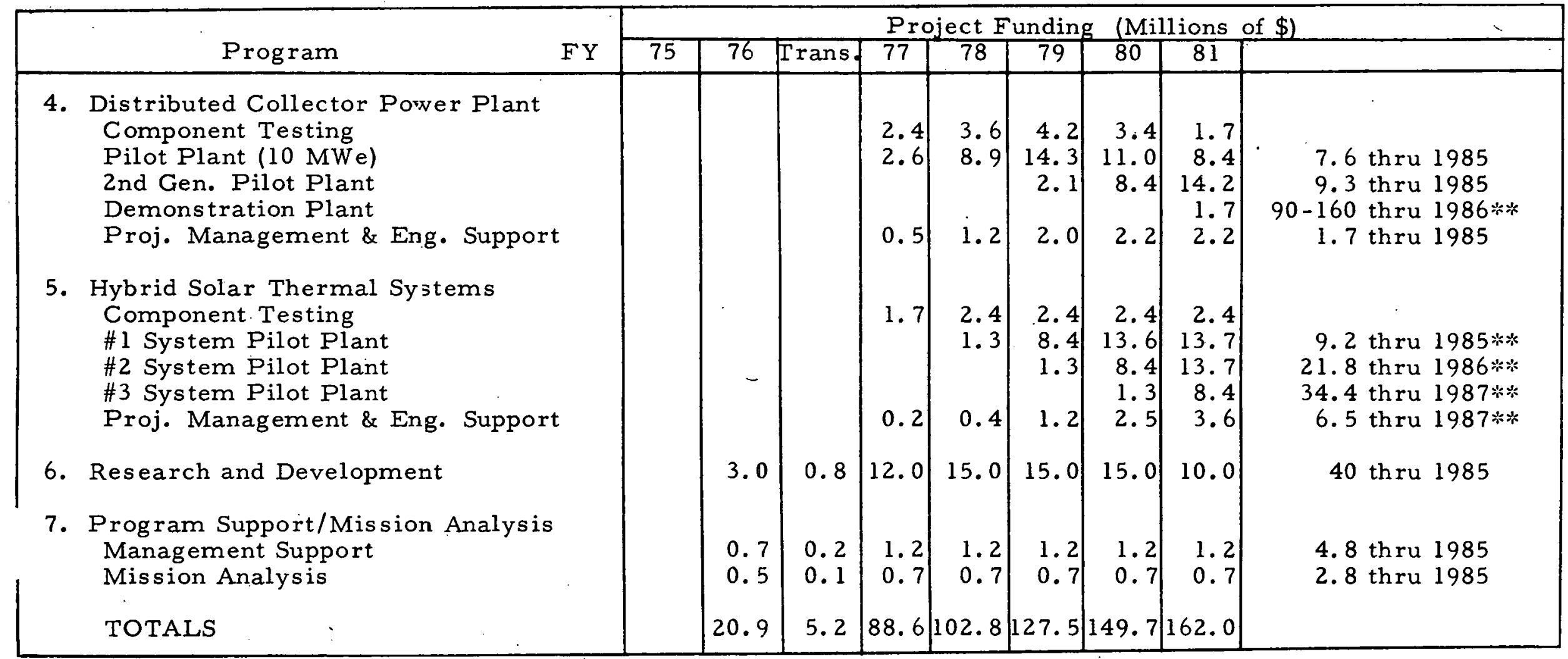

** UTILITIES PARTICIPATION

Assumes $50 \%$ funding by Utilities for demonstration plants and $100 \%$ funding by utilities for commercial plants with low interest government loans for first gene ration commercial plants. 
SOLAR THERMAL SUBPROGRAM

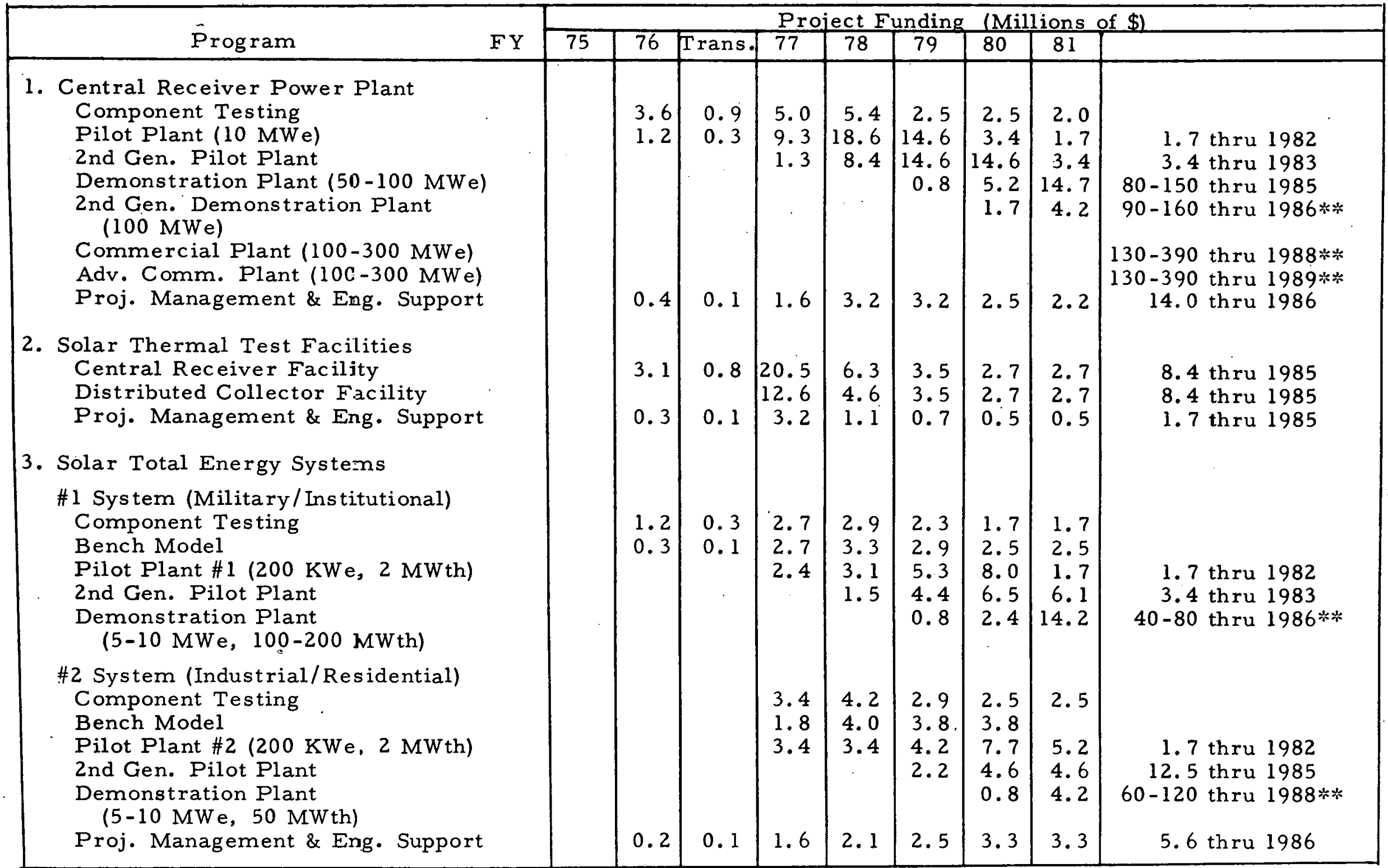




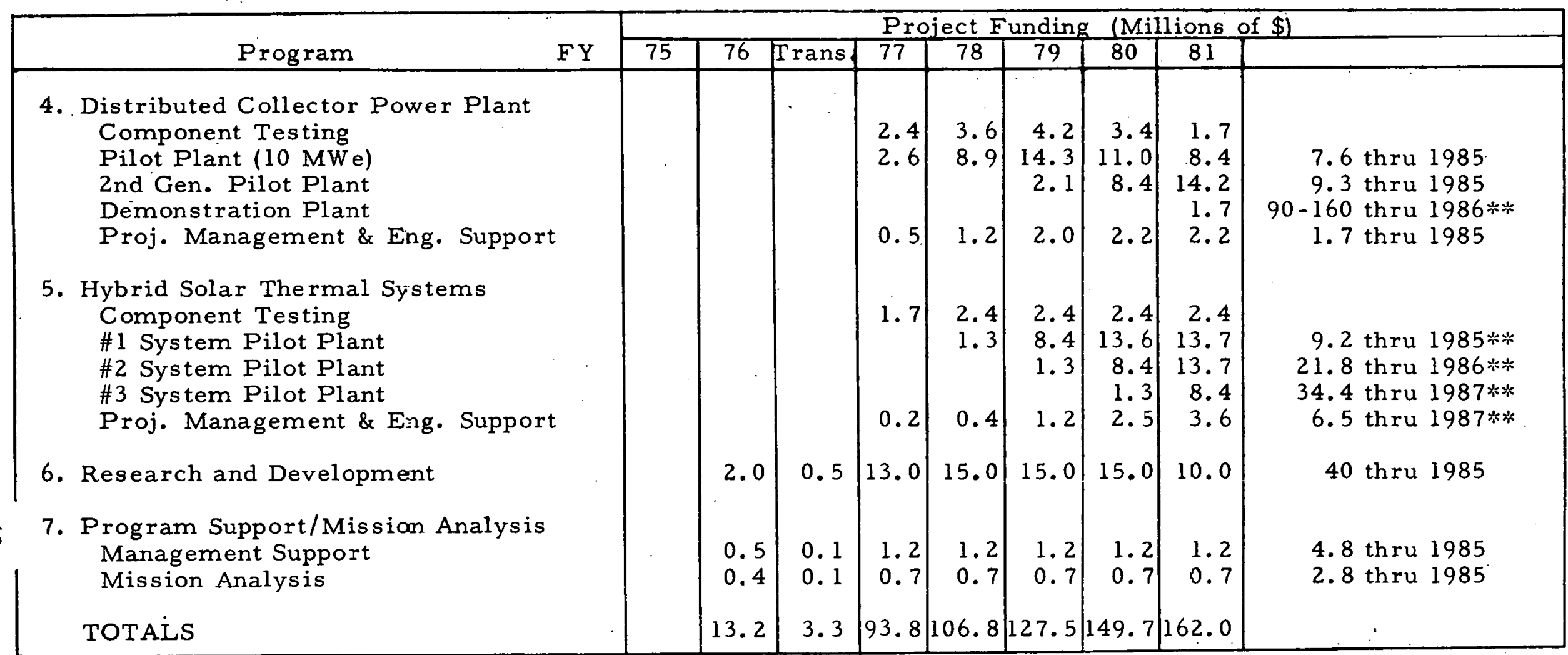

\section{UTILITIES PARTICIPATION}

Assumes $50 \%$ funding by Utilities for demonstration plants and $100 \%$ funding by utilities for commercial plants with low interest government loans for first generation commercial plants. 


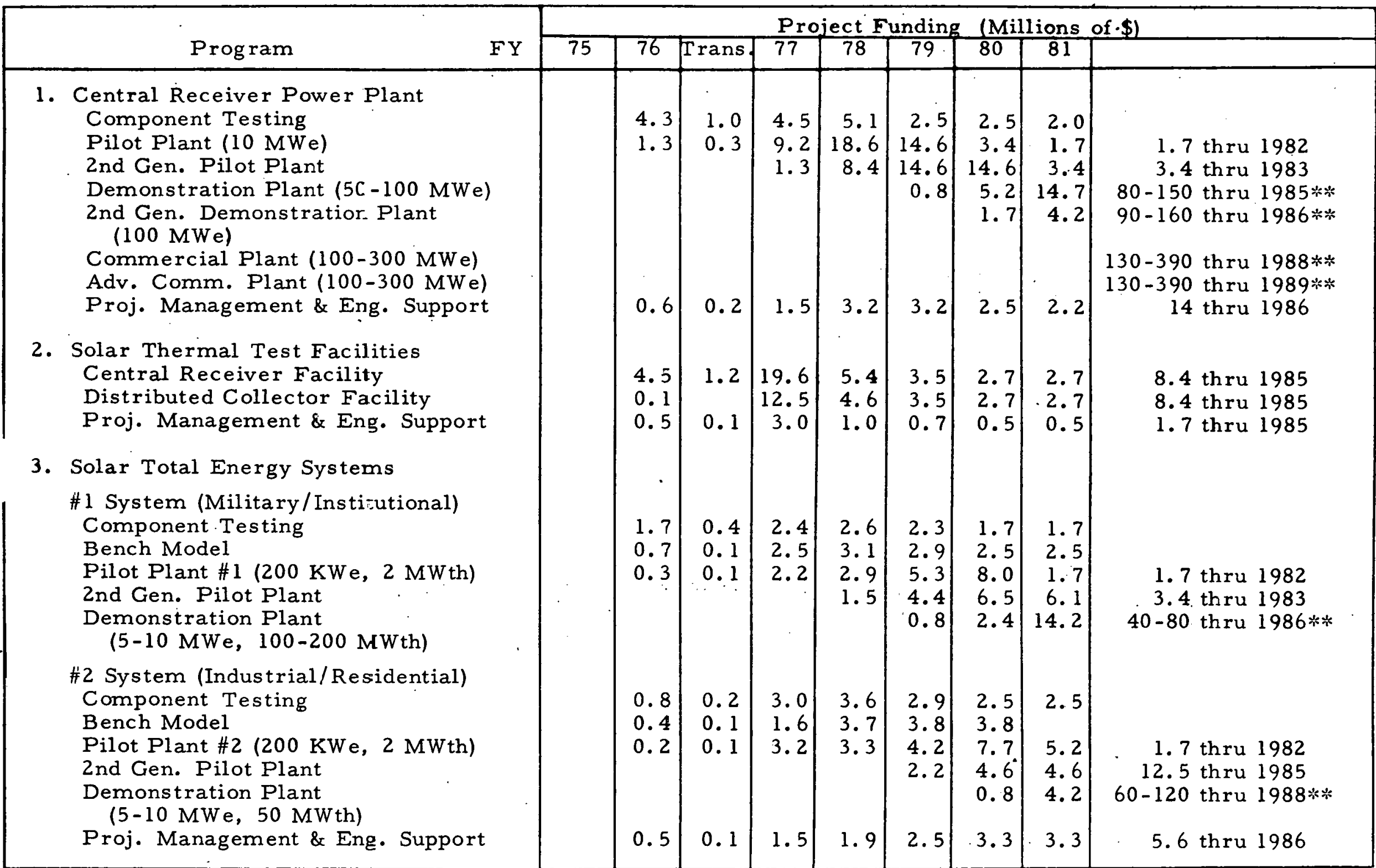


SOLAR THERMAL 'SUBPROGRAM

\begin{tabular}{|c|c|c|c|c|c|c|c|c|c|c|}
\hline & \multirow{2}{*}{ Program } & \multicolumn{9}{|c|}{ Project Funding (Missions of \$) } \\
\hline & & 75 & 76 & Trang & 77 & 78 & 79 & 80 & 81 & \\
\hline 4. & $\begin{array}{l}\text { Distributed Collector Power Plant } \\
\text { Component Testing } \\
\text { Pilot Plant (10 MWe) } \\
\text { 2nd Gen. Pilot Plant } \\
\text { Demonstration Plant } \\
\text { Proj. Management \& Eng. Support }\end{array}$ & & & & $\begin{array}{l}2.4 \\
2.6 \\
0.5\end{array}$ & $\begin{array}{l}3.6 \\
8.9 \\
1.2\end{array}$ & $\begin{array}{r}4.2 \\
14.3 \\
2.1 \\
2.0\end{array}$ & $\begin{array}{r}3.4 \\
11.0 \\
8.4 \\
2.2\end{array}$ & $\begin{array}{r}1.7 \\
8.4 \\
14.2 \\
1.7 \\
2.2\end{array}$ & $\begin{array}{r}7.6 \text { thru } 1985 \\
9.3 \text { thru } 1985 \\
90-160 \text { thru } 1986 \% * \\
1.7 \text { thru } 1985\end{array}$ \\
\hline 5. & $\begin{array}{l}\text { Hybrid Solar Thermal Systems } \\
\text { Component Testing } \\
\text { \#1 System Pilot Plant } \\
\text { \#2 System Pilot Plant } \\
\text { \#3 System Pilot Plant } \\
\text { Proj. Management \& Eng. Support }\end{array}$ & & & & 0.2 & $\begin{array}{l}2.4 \\
1.3\end{array}$ & $\begin{array}{l}2.4 \\
8.4 \\
1.3 \\
1.2\end{array}$ & $\begin{array}{r}2.4 \\
13.6 \\
8.4 \\
1.3 \\
2.5\end{array}$ & $\begin{array}{r}2.4 \\
13.7 \\
13.7 \\
8.4 \\
3.6\end{array}$ & $\begin{array}{r}9.2 \text { thru } 1985 \\
21.8 \text { thru } 1986 \\
34.4 \text { thru } 1987 \\
6.5 \text { thru } 1987\end{array}$ \\
\hline & Research and Development & & 4.0 & 1.0 & 12.5 & 15.0 & .15 .0 & 15.0 & 10.0 & 40 thru 1985 \\
\hline 7. & $\begin{array}{l}\text { Program Support/Mission Analysis } \\
\text { Management Support } \\
\text { Mission Analysis }\end{array}$ & & $\begin{array}{l}0.6 \\
0.4\end{array}$ & $\begin{array}{l}0.2 \\
0.1\end{array}$ & $\begin{array}{l}1.2 \\
0.7\end{array}$ & $\begin{array}{l}1.2 \\
0.7\end{array}$ & $\begin{array}{l}1.2 \\
0.7\end{array}$ & $\begin{array}{l}1.2 \\
0.7\end{array}$ & $\begin{array}{l}1.2 \\
0.7\end{array}$ & $\begin{array}{l}4.8 \text { thru } 1985 \\
2.8 \text { thru } 1985\end{array}$ \\
\hline & TOTALS & & 20.9 & 5.2 & 89.8 & 101.6 & 127.5 & 149.7 & 162.0 & \\
\hline
\end{tabular}

\section{** UTILITIES PARTICIPATION}

Assumes $50 \%$ funding by Utilities for demonstration plants and $100 \%$ funding by utilities for commercial plants with low interest government loans for first generation commercial plants. 


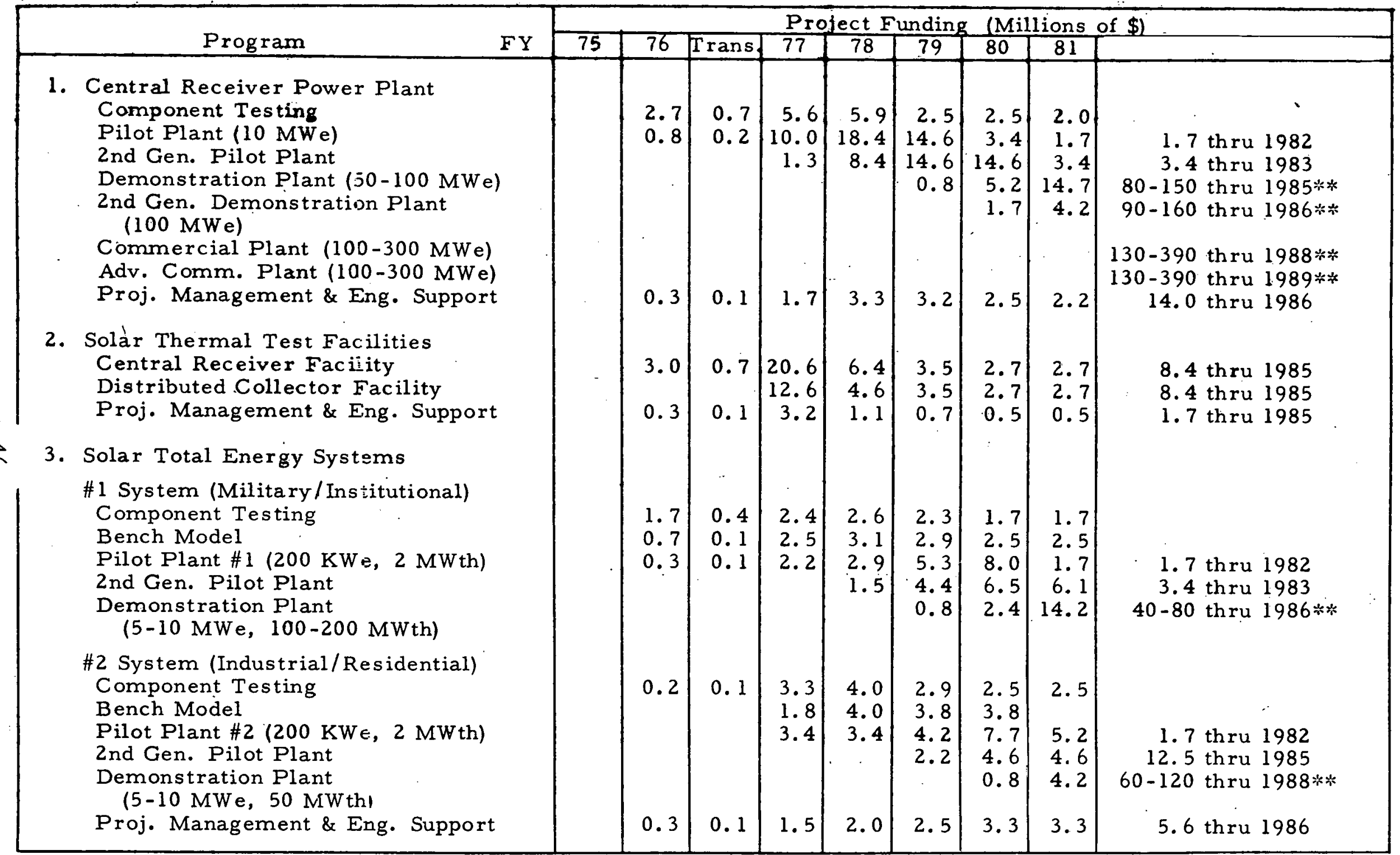


Alternative Plan \#2

FY $1976 \$ 13.2 \mathrm{M}$ (Continued)
Table V

BUDGET SUMMARY

SOLAR THERMAL SUBPROGRAM

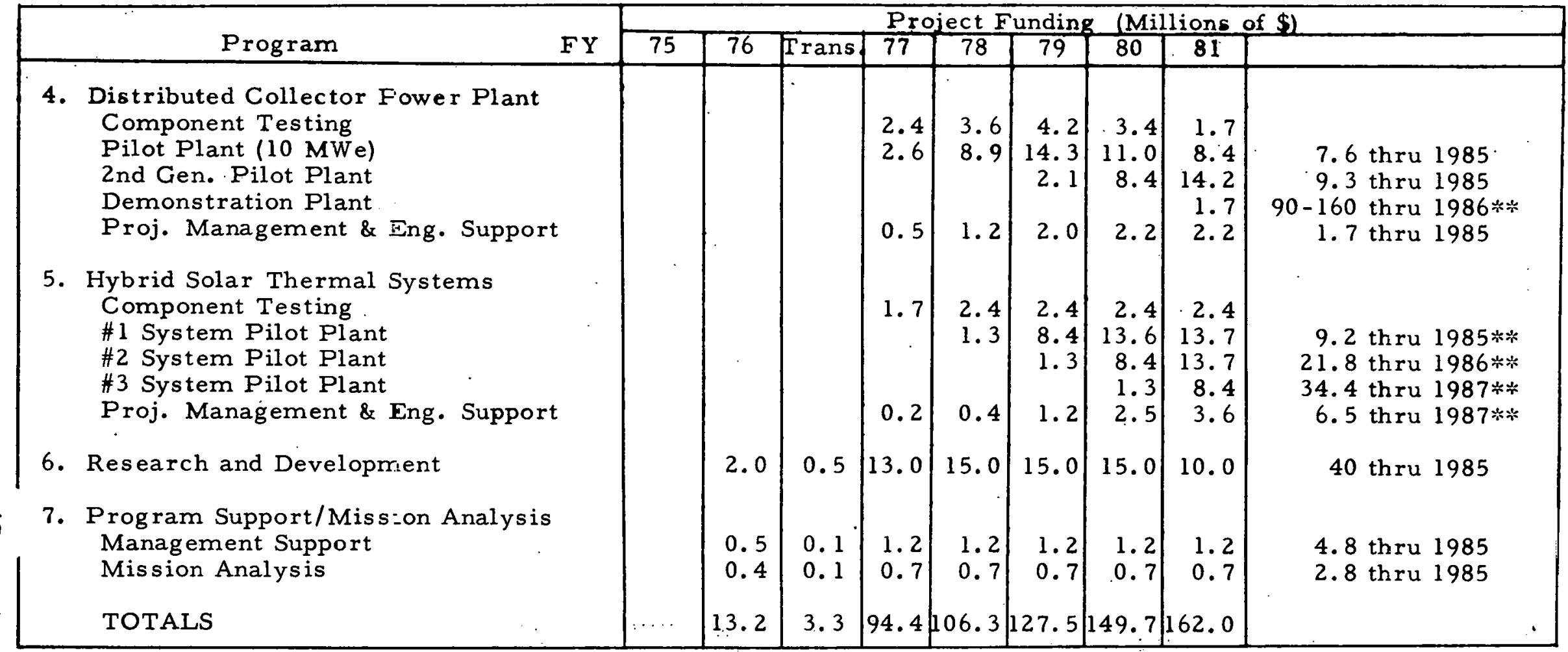

** UTILITIES PARTICIPATION

Assumes $50 \%$ funding by Utilities for demonstration plants and $100 \%$ funding by utilities for commercial plants with low interest government loans for first generation comme rcial plants. 


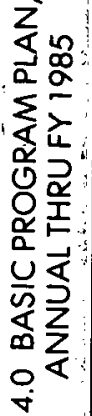

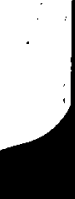




\section{SECTION 4.0 BASIC PROGRAM PLAN,}

ANNUAL THRU FY 1985

Section 4.0 consists of the extension of the Basic Plan to show funding detail beyond FY 1981 to include FY 1985. The revised formats used were as requested by Dr. Mock about 21 April 1975 and are included as funding Tables VI, VII, and VIII, and a combined Milestone and Budget Summary, Table IX. The contents of the tables are as follows:

Table VI "Solar Thermal Subprogram Planning/Funding Requirements"

Table ViI. "Solar Thermal Subprogram Element Funding Requirements"

Table VIII "Solar Thermal Subprogram Operating, Capital Equipment, and Plant Construction Expense Summaries" .

Table IX "Solar Thermal Subprogram Major Results, Key Decision Dates, and Budget Summary" 
TABLE VI. SOLAR THERMAL SUBPROGRAM PLANNING/FUNDING REQUIREMENTS

\begin{tabular}{|c|c|c|c|c|c|c|c|c|c|c|c|c|c|}
\hline & & 75 & 76 & $\begin{array}{l}\text { Trans } \\
\text { Qtr. }\end{array}$ & 77 & 78 & 79 & $\cdot 80$ & 81 & 82 & 83 & 84 & 85 \\
\hline 1. & $\begin{array}{l}\text { Central Receiver Power- } \\
\text { plant }\end{array}$ & 5.1 & 9.6 & 2.1 & 15.0 & 33.4 & 35.7 & 29.9 & 28.2 & 49.2 & 67.5 & 95.8 & 85.8 \\
\hline 2. & Test Facilities & & 6.8 & 1.8 & 33.9 & 9.8 & 6.5 & 5.9 & 5.9 & 4.7 & 4.6 & 4.6 & 4.6 \\
\hline 3 . & Total Energy System & 2.3 & 5.9 & 1.3 & 15.3 & 21.8 & 31.3 & 43.8 & 46.0 & 51.4 & 53.5 & 57.5 & 47.5 \\
\hline 4. & $\begin{array}{l}\text { Distributed Collector } \\
\text { Power Plant }\end{array}$ & 0.1 & & & 5.5 & 13.7 & 22.6 & 25.0 & 28.2 & 40.3 & 51.0 & 67.8 & 30.8 \\
\hline 5. & $\begin{array}{l}\text { Hybrid Solar Thermal } \\
\text { System }\end{array}$ & & & & 1.9 & 4.1 & 13.3 & 28.2 & 41.8 & 33.9 & 21.9 & 8.7 & 5.4 \\
\hline 6. & $\begin{array}{l}\text { Research and Develop- } \\
\text { ment }\end{array}$ & 1.9 & 6.0 & $1: 5$ & 10.0 & 15.0 & 15.0 & 15.0 & 10.0 & 10.0 & 10.0 & 10.0 & 10.0 \\
\hline 7. & Program Support & 0.6 & 1.2 & 0.4 & 1.9 & 1.9 & 1.9 & 1.9 & 1.9 & 1.9 & 1.9 & 1.9 & 1.9 \\
\hline & & 10.0 & 29.5 & 7.1 & 83.5 & 99.7 & 126.3 & 149.7 & 162.0 & 191.4 & 210.4 & 246.3 & 186.0 \\
\hline & $\begin{array}{l}\text { rating Expenses } \\
\text { bital Equipment } \\
\text { nt Construction }\end{array}$ & 10.0 & $\begin{array}{r}28.0 \\
0.7 \\
0.8\end{array}$ & $\begin{array}{l}6.1 \\
0.2 \\
0.8\end{array}$ & $\begin{array}{l}47.3 \\
11.9 \\
24.3\end{array}$ & $\begin{array}{l}56.1 \\
16.5 \\
27.1\end{array}$ & $\begin{array}{l}66.2 \\
27.9 \\
32.2\end{array}$ & $\begin{array}{l}77.4 \\
32.2 \\
40.1\end{array}$ & $\begin{array}{l}75.2 \\
49.3 \\
37.5\end{array}$ & $\begin{array}{l}53.4 \\
55.0 \\
83.0\end{array}$ & $\begin{array}{r}50.9 \\
48.2 \\
111.3\end{array}$ & $\begin{array}{r}48.3 \\
34.0 \\
164.0\end{array}$ & $\begin{array}{r}46.0 \\
26.0 \\
114.0\end{array}$ \\
\hline To & & 10.0 & 29.5 & 7.1 & 83.5 & 99.7 & 126.3 & 149.7 & 162.0 & 191.4 & 210.4 & 246.3 & 186.0 \\
\hline & $\begin{array}{l}\text { rating Expense Escalation } \\
\text { tor }\end{array}$ & & 1.00 & 1.00 & 1.08 & 1.08 & 1.08 & 1.08 & 1.08 & 1.08 & 1.08 & 1.08 & 1.08 \\
\hline \multicolumn{3}{|c|}{ Plant Escalation Factor } & 1.00 & 1.00 & 1.22 & 1.30 & 1.38 & 1.47 & 1.57 & 1.67 & 1.67 & 1.67 & 1.67 \\
\hline
\end{tabular}

Note: Utilities are encouraged to contribute as much as $50 \%$ to demonstration plant development, participation amounting to 200-320 million dollars thru FY 1985. Utilities are expected to provide the commercial plant development which amounts to 260-780 million dollars thru FY 1987 and are not included in the run-out totals. 


\section{Central Receiver Power Plant}

Component Tests:

$$
\text { Operating Expenses }
$$

Pilot Plant:

Operating Expenses

Capital Equipment

Plant Construction

2nd Generation Pilot Plant

Operating Expenses

Capital Equipment

Plant Construction

Demonstration Plant (1)

Operating Expenses

Yั

Capital Equipment

Plant Construction

Adv. Demonstration Plant (1)

Operating Expenses

Capital Equipment

Plant Construction

Commercial Plant

Operating Expenses

Capital Equipment

Plant Construction

(2)

$130-390$ thru FY 1987

(2) $130-390$ thru FY 1989

Adv. Commercial Plant
TABLE VII: Solar Thermal Subprogram

Element Funding Requirements

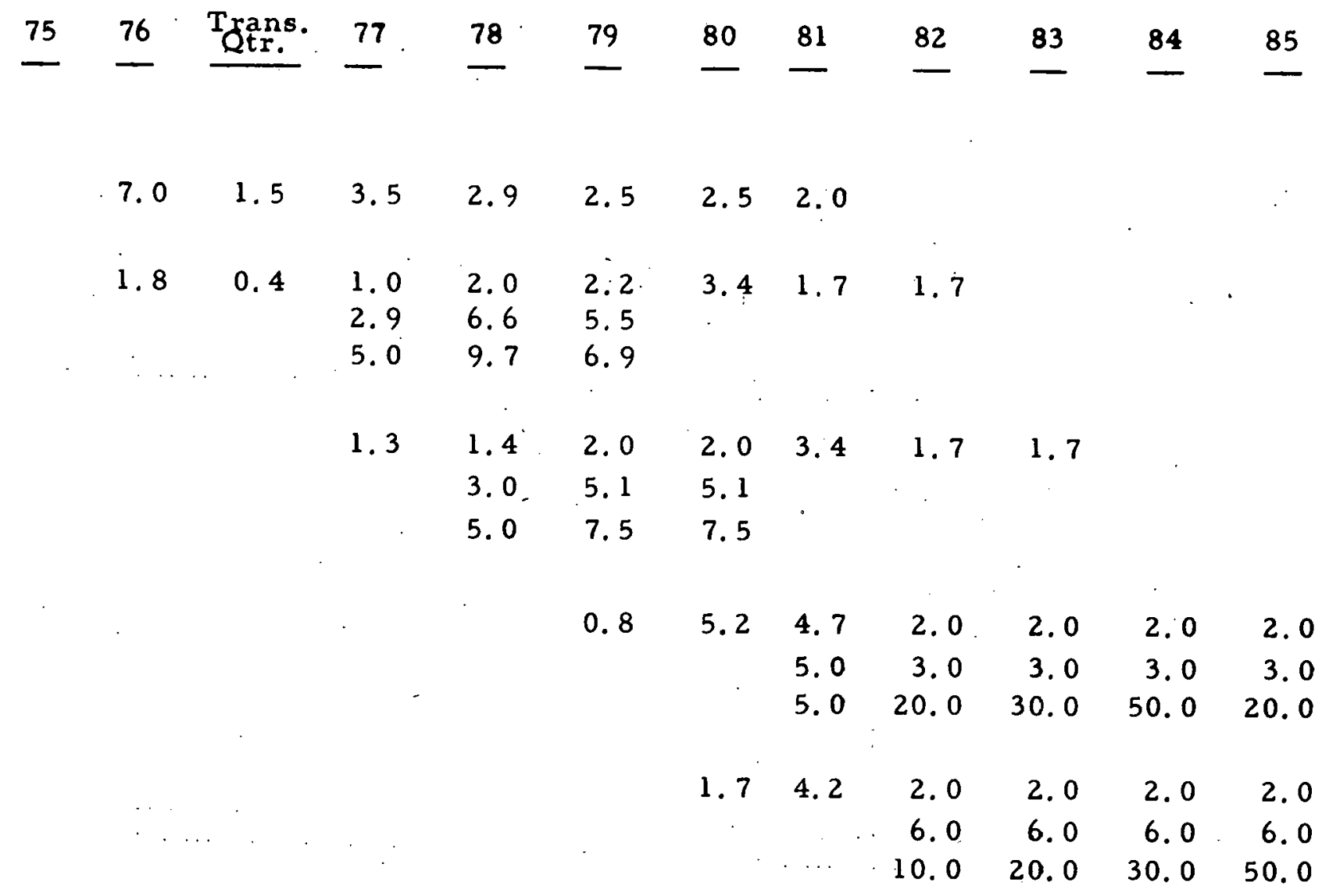

Project Management

\begin{tabular}{crrrrrrrrrrrrrrrr} 
Operating Expenses & 0.8 & 0.2 & 1.3 & 2.8 & 3.2 & 2.5 & 2.2 & 2.8 & 2.8 & 2.8 & 2.8 \\
\hline Totals & & & & & & & & & & & & \\
Operating Expenses & 9.6 & 2.1 & 7.1 & 9.1 & 10.7 & 17.3 & 18.2 & 10.2 & 8.5 & 6.8 & 6.8 \\
Capital Equipment & & & 2.9 & 9.6 & 10.6 & 5.1 & 5.0 & 9.0 & 9.0 & 9.0 & 9.0 \\
Plant Construction & & & 5.0 & 14.7 & 14.4 & 7.5 & 5.0 & 30.0 & 50.0 & 80.0 & 70.0 \\
\hline Totals & 9.6 & 2.1 & 15.0 & 33.4 & 35.7 & 29.9 & 28.2 & 49.2 & 67.5 & 95.8 & 85.8
\end{tabular}


TABLE VI Jont.)

\begin{tabular}{|c|c|c|c|c|c|c|c|c|c|c|c|c|}
\hline 2. Test Facility & 75 & 76 & $\begin{array}{l}\text { Trans. } \\
\text { Qtr. }\end{array}$ & 77 & 78 & 79 & 80 & 81 & 82 & 83 & 84 & 85 \\
\hline $\begin{array}{l}\text { Central Receiver } \\
\text { Operating Expenses }\end{array}$ & & 3.0 & 0.2 & 3.6 & 2.4 & 2.5 & 2.7 & 2.7 & 2.1 & 2.1 & 2.1 & 2.1 \\
\hline Captial Equipment & & 0.7 & 0.2 & 4.0 & 2.0 & 1.0 & & & & & & \\
\hline Plant Construction & & 0.8 & 0.8 & 12.0 & 1.0 & & & & . & & & \\
\hline $\begin{array}{l}\text { Distributed Collector } \\
\text { Operating Expenses }\end{array}$ & & 1.7 & 0.4 & 2.5 & 1.6 & 1.5 & 2.7 & 2.7 & 2.1 & 2.1 & 2.1 & 2.1 \\
\hline Capital Equipment & & & & 4.5 & 1.0 & 1.0 & & & & $\therefore$ & & \\
\hline Plant Construction & & & & 4.5 & 1.0 & & & & & & & \\
\hline $\begin{array}{l}\text { Project Management } \\
\text { Operating Expenses }\end{array}$ & & 0.6 & 0.2 & 2.8 & 0.8 & 0.5 & 0.5 & 0.5 & 0.5 & 0.4 & 0.4 & 0.4 \\
\hline $\begin{array}{l}\text { TOTALS } \\
\text { Operating Expenses }\end{array}$ & & 5.3 & 0.8 & 8.9 & 4.8 & 4.5 & 5.9 & 5.9 & 4.7 & 4.6 & 4.6 & 4.6 \\
\hline Capital Equipment & & 0.7 & 0.2 & 8.5 & 3.0 & 2.0 & & & & & & \\
\hline Plant Construction & & 0.8 & 0.8 & 16.5 & 2.0 & & & & & & & \\
\hline TOTALS & & 6.8 & 1.8 & 33.9 & 9.8 & 6.5 & 5.9 & 5.9 & 4.7 & 4.6 & 4.6 & 4.6 \\
\hline
\end{tabular}


TABLE . I (Cont.)

3. Solar Total Energy Systems

75

\#1 System Component Testing Operating Expenses

Bench Model Operation

Pilot Plant \#1

Operating Expenses

Captial Equipment

Plant Construction

2nd Gen. Pilot Plant

Operating Expenses

Captial Equipment

Plant Costruction

Demonstration (1)

Operating Expenses

U Capital Equipment

Plant Construction

\#2 System

Component Tests Operation

Bench Model

Operation

Pilot Plant \#2

Operating Expenses

Captial Equipment

Plant Construction

Trans.

$\begin{array}{llllllllllll}76 & \text { Qtr. } & 77 & 78 & 79 & 80 & 81 & 82 & 83 & 84 & 85\end{array}$

$\begin{array}{lllllllllll}1.7 . & 0.4 & 2.4 & 2.6 & 2.3 & 1.7 & 1.7 & & & & \\ 0.7 & 0.1 & 2.5 & 3.1 & 2.9 & 2.5 & 2.5 & & & & \\ 0.3 & 0.1 & 0.3 & 0.3 & 0.7 & 0.7 & 0.7 & 0.5 & 0.4 & 0.4 & 0.4 \\ & & 0.5 & 1.0 & 1.6 & 2.5 & 1.0 & & & & \\ & & 1.4 & 1.6 & 3.0 & 4.8 & & & & \end{array}$

$\begin{array}{llllllll}0.5 & 0.6 & 1.0 & 0.5 & 0.4 & 0.4 & 0.3 & 0.3 \\ & 1.0 & 2.0 & 2.0 & 1.0 & 1.0 & & \\ 1.0 & 2.8 & 3.5 & 3.6 & & & & \end{array}$

$\begin{array}{rrrrrrr}0.8 & 2.4 & 2.6 & 3.0 & 3.0 & 2.0 & 2.0 \\ & & 5.6 & 5.0 & 5.0 & 5.0 & 5.0 \\ & & 6.0 & 8.0 & 12.0 & 18.0 & 12.0\end{array}$

$\begin{array}{lllllll}1.7 & 0.4 & 2.4 & 3.1 & 2.9 & 2.5 & 2.5 \\ 0.7 & 0.1 & 1.4 & 3.6 & 3.8 & 3.8 & \end{array}$

$\begin{array}{lllllllll}0.3 & 0.1 & 1.8 & 0.4 & 0.5 & 1.0 & 1.0 & 0.4 & 0.3\end{array}$

$\begin{array}{lllll}1.0 & 0.7 & 3.7 & 3.2 & 1.0\end{array}$

$\begin{array}{lllll}1.4 & 1.8 & 3.0 & 3.0 & 1.0\end{array}$ 
TABL VII (Cont.)

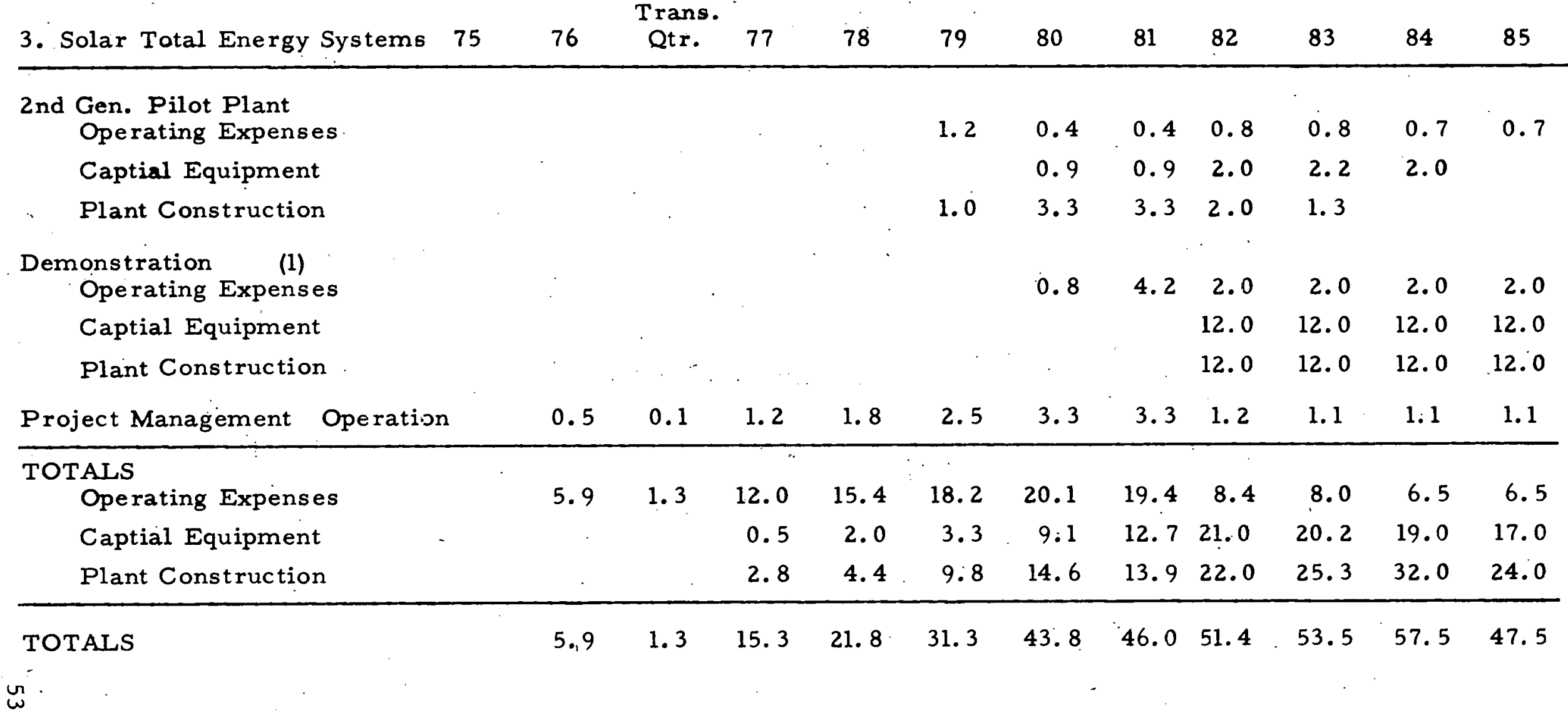




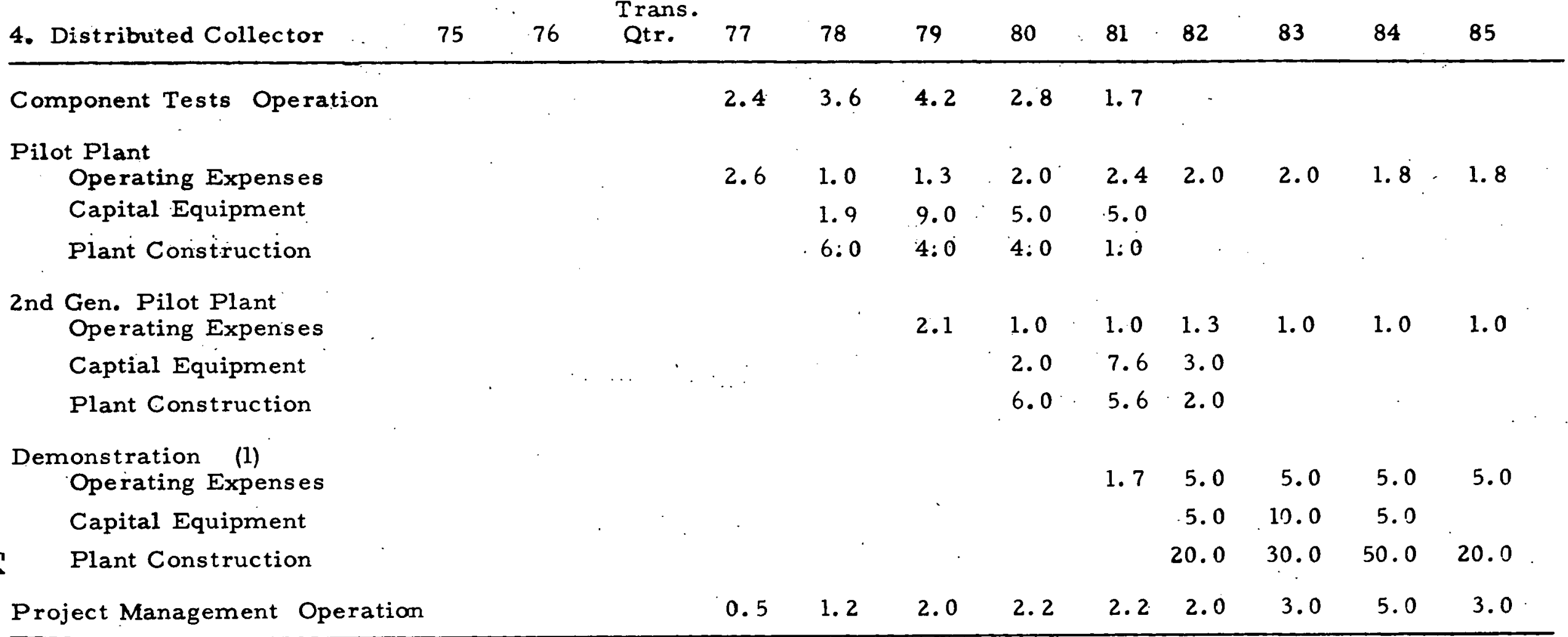

\begin{tabular}{|c|c|c|c|c|c|c|c|c|c|}
\hline $\begin{array}{l}\text { TOTALS } \\
\text { Operating Expenses }\end{array}$ & 5.5 & 5.8 & 9.6 & 8.0 & 9.0 & 10.3 & 11.0 & 12.8 & 10.8 \\
\hline Capital Equipment & & 1.9 & 9.0 & 7.0 & 12.6 & 8.0 & 10.0 & 5.0 & \\
\hline Plant Construction & & 6.0 & 4.0 & 10.0 & 6.6 & 22.0 & $30 . \dot{0}$ & 50.0 & 20.0 \\
\hline TOTALS & 5.5 & 13.7 & 22.6 & 25.0 & 28.2 & 40.3 & 51.0 & 67.8 & 30.8 \\
\hline
\end{tabular}


TABLE VII (Cont.)

$\begin{array}{lllllllllllll}75 & 76 & \begin{array}{c}\text { Trans. } \\ \text { Qtr. }\end{array} & 77 & 78 & 79 & 80 & 81 & 82 & 83 & 84 & 85\end{array}$

5. Hybrid Solax Thermal Systems

Component Testing

Operating Expenses

\#1 System Pilot Plant

Operating Expenses

Capital Equipment

Plant Construction

\#2 System Pilot Plant

Operating Expenses

Capital Equipment

Plant Construction

\#3 System Pilot Plant

Operating Expenses.

ज
1.7

2.4

2.4

$2.4 \quad 2.4$

$\begin{array}{lllllllll}1.3 & 1.4 & 1.6 & 1.7 & 1.8 & 1.8 & 1.8 & 1.8 \\ 3.0 & 8.0 & 8.0 & 1.0 & & & \\ 4.0 & 4.0 & 4.0 & 1.0 & & & \\ & & & & & & \\ 1.3 & 1.4 & 1.7 & 1.7 & 1.7 & 1.7 & 1.7 \\ & 3.0 & 8.0 & 8.0 & 1.0 & & \\ & 4.0 & 4.0 & 4.0 & 2.0 & & \end{array}$

$\begin{array}{llllll}1.3 & 1.4 & 1.4 & 1.4 & 1.4 & 1.4 \\ 3.0 & 8.0 & 8.0 & 1.0 & \\ 4.0 & 4.0 & 4.0 & 2.0\end{array}$

Project Management \& Eng. Sup.

Operating Expenses

0.2

0.4

1.2

$2: 5$

3.6

3.0

2.0

0.8

0.5

Totals

Operating Expenses.

1.94 .1

6.

$9.2 \quad 10.3 \quad 7.9$

6.9

5.7

5.4

Capital Equipment

3.

11.019 .

17.0

9.0

1. 0

Plant Construction

4.

$8.0 \quad 12.0$

9. 0

6.0

2. 0

TOTALS

1.9

4. 1

13.3

28.241 .8

33.9

21.9

8. 7

5. 4 
TABLE VII. Solar Thermal Program Element (Cont.) Funding Requirements

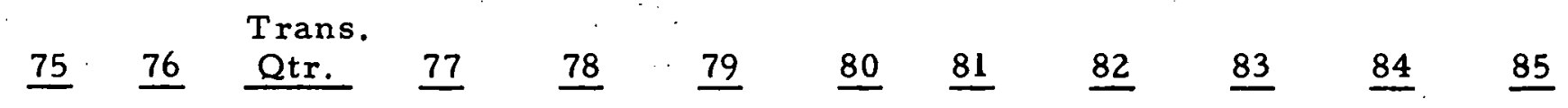

6. Research and Development

Component Development

8. 0

8. 0

8. 0 . 5.0

5.0

5.0

5.0

5.0

Improved Coatings \& Materials

0.9

$0.2 \quad 1.5$

2. 0

2. 0

2. $0 \quad 1.5$

1.5

1.5

1. 5

1. 5

Advanced Subsystems, Systems \& Concepts

$\begin{array}{llll}1.2 & 0.3 & 2.0 & 3.0\end{array}$

3. 0

3. 0

2. 0

2. 0

2. 0

2. 0

2. 0

Institutional, Safety, Siting \& Environmental

$0.9 \cdot 0.2 \quad 1.5 \cdot 2: 0$

2.0

$2.0 \quad 1.5$

1.

$1.5 \quad 1.5$

Total Operating Expenses

$6.0 \quad 1.5 \quad 10$.

$0.0 \quad 15.0$

15.0

15.010 .0

10.

10.

6.01 .5

10.0

15.0

15.0

$15.0 \quad 10.0$

10.0

10.0

10.0

10.0

\section{Program Support}

Operating Expenses

$\begin{array}{llll}0.6 & 1.2 & 0.4 & 1.9\end{array}$

1.9

$1.9 \cdot 1.9$

1.9 .1 .9

1.9

1.9

1. 9

1.9

(1) Utility participation anticifated as much as $50 \%$ for demonstration plant development.

(2) Utility development of Commercial plants - funding not included in run-out totals. 
TABLE VIII. Solar Thermal Subprogram

Operating, Capital Equipment and Plant Construction

Expense Summaries

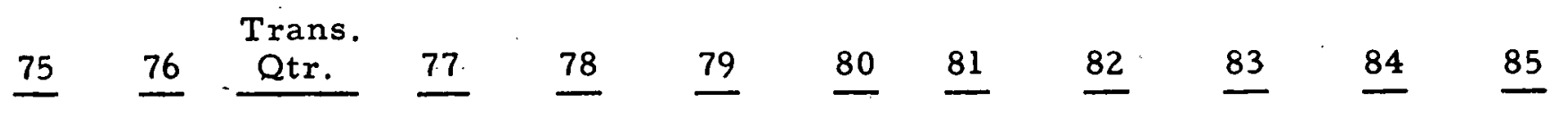

\section{Operating Expenses}

1. Central Receiver Power Plant

$\begin{array}{lllllllllll}9.6 & 2.1 & 7.1 & 9.1 & 10.7 & 17.3 & 18.2 & 10.2 & 8.5 & 6.8 & 6.8\end{array}$

2. Test Facilities

$5.3 \quad 0.8 \quad 8.9$

$\begin{array}{llll}4.8 & 4.5 & 5.9 & 5.9\end{array}$

4. 7

4.6

4.6

4.6

3. Total Energy Systems

5.

4. Distributed Collector Power Plant

1. 3

12.0

$15.4 \quad 18.2 \quad 20.1 \quad 19.4$

8.4

8. 0

6.5

6.5

5. Hybrid Solar Thermal System $5.5 \quad 5.8 \quad 9.6$

8.09 .0

10.3

íl. 0

$12.8 \quad 10.8$

6. Research and Development

1.9

4.16 .3

9.210 .8

7. 9

6.9

5. 7

5.4

7. Program Support

$\checkmark$

Totals

\begin{tabular}{rrrrrrrrrrr}
6.0 & 1.5 & 10.0 & 15.0 & 15.0 & 15.0 & 10.0 & 10.0 & 10.0 & 10.0 & 10.0 \\
1.2 & 0.4 & 1.9 & 1.9 & 1.9 & 1.9 & 1.9 & 1.9 & 1.9 & 1.9 & 1.9 \\
\hline 28.0 & 6.1 & 47.3 & 56.1 & 66.2 & 77.4 & 75.2 & 53.4 & 50.9 & 48.3 & 46.0
\end{tabular}

\section{Capital Equipment Expenses}

1. Central Receiver Power Plant

$\begin{array}{lllllllll}2.9 & 9.6 & 10.6 & 5.1 & 5.0 & 9.0 & 9.0 & 9.0 & 9.0\end{array}$

2. Test Facilities

$\begin{array}{lllll}0.7 & 0.2 & 8.5 & 3.0 & 2.0\end{array}$

3. Total Energy Systems

$0.5 \quad 2.0 \quad 3.3$.

9.112 .7

$1.9 \quad 9.0 \quad 7.012 .6$

21.0

$20.219 .0 \quad 17.0$

4. Distributed Collector Power Plant

5. Hybrid Solar Thermal Systems

\section{Totals}

\section{Plant Construction Expenses}

1. Central Receiver Power Plant.

2. Test Facilities.

3. Total Energy Systems

4. Distributed Collector

5. Hybrid Solar Thermal Systems

Totals

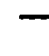

0.7 .0$.

\begin{tabular}{|c|c|c|c|c|c|c|c|c|c|c|}
\hline \multirow{3}{*}{0.8} & \multirow{3}{*}{0.8} & 5.0 & 14.7 & 14.4 & 7.5 & 5.0 & 30.0 & 50.0 & 80.0 & 70.0 \\
\hline & & 16.5 & 2.0 & & & & & & & \\
\hline & & 2.8 & $\begin{array}{l}4.4 \\
6.0\end{array}$ & $\begin{array}{l}9.8 \\
4.0 \\
4.0\end{array}$ & $\begin{array}{r}14.6 \\
10.0 \\
8.0\end{array}$ & $\begin{array}{r}13.9 \\
6.6 \\
12.0\end{array}$ & $\begin{array}{r}22.0 \\
22.0 \\
9.0\end{array}$ & $\begin{array}{r}25.3 \\
30.0 \\
6.0\end{array}$ & $\begin{array}{r}32.0 \\
50.0 \\
2.0\end{array}$ & $\begin{array}{c}24.0 \\
20.0 \\
-\end{array}$ \\
\hline 0.8 & 0.8 & $24: 3$ & 27.1 & 32.2 & 40.1 & 37.5 & 83.0 & 111.3 & 164.0 & $114: 0$ \\
\hline 29.5 & 7.1 & 83.5 & 99.7 & 126.3 & 149.7 & 1620 & 191.4 & 210.4 & 246.3 & 186.0 \\
\hline
\end{tabular}


TABLE IX

SOLAR THERMAL SUBPROGRAM

MAJOR RESULTS, KEY DECISION DATES AND BUDGET SUMMARY

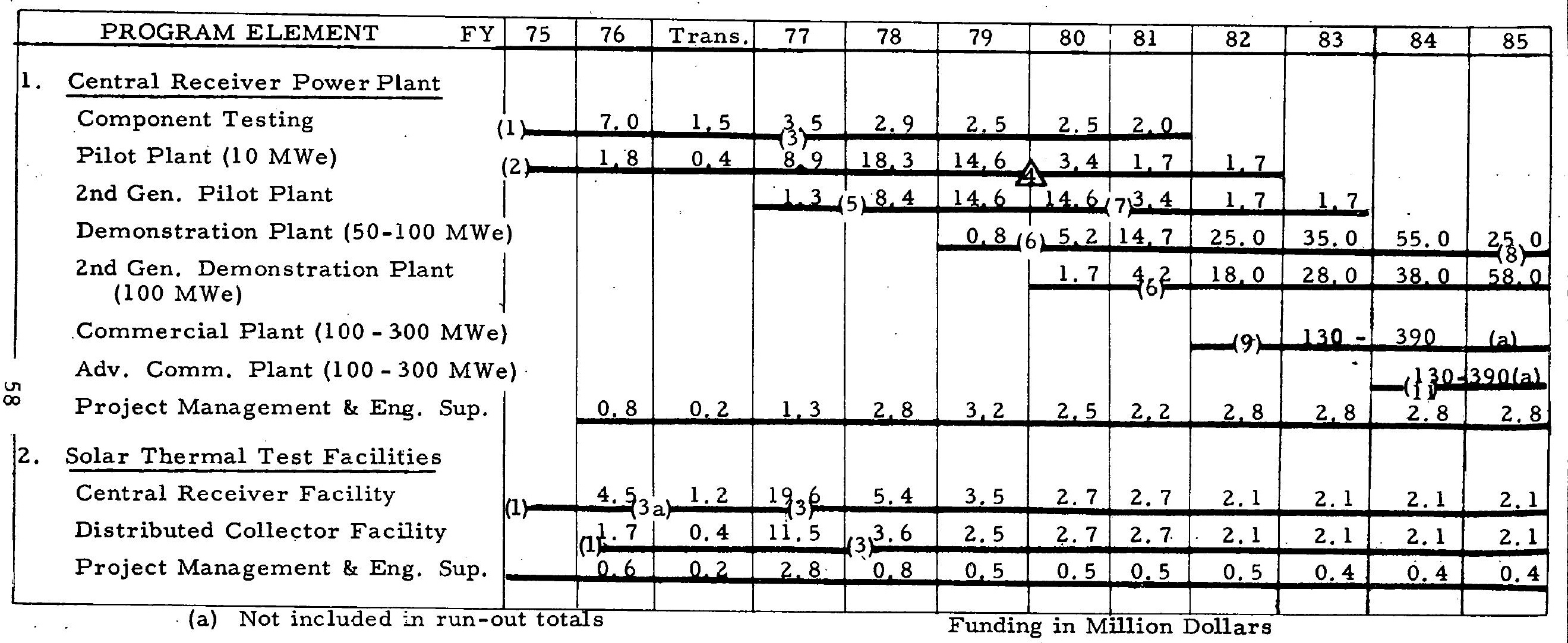

Milestones

(1) Decision to Build Bench Model/Test Facility

(2) Decision to Build Piföt Plant

(3) Bench Model/Facility in Operation (3a) Partial Capability

(4) Pilo't Plant Checked out and Operating

(5) Decision to Start Second Generation Pilot Plant

(6) Decision to Build Demonstration Plants

(7) Second Generation Plant in Operation

(8) Demonstration Plant in Operation

(9) Decision to Build Commercial Plant

(10) Commercial Plant in Operation FY 1987

(11) Decision to Build Advance Comm. Plant

(12) Advance Commercial Plant in Operation FY 1989

Note: Utilities are encouragec to contribute as much as $50 \%$ to demonstration plant development, participation amounting to 200-320 million dollars thru FY 1985. Utilities are expected tc. provide the commercial plant development which amounts to 260-780 million dollars thru FY 1987 and are not included in the run-out totals. 
TABLE IX (Cont.)

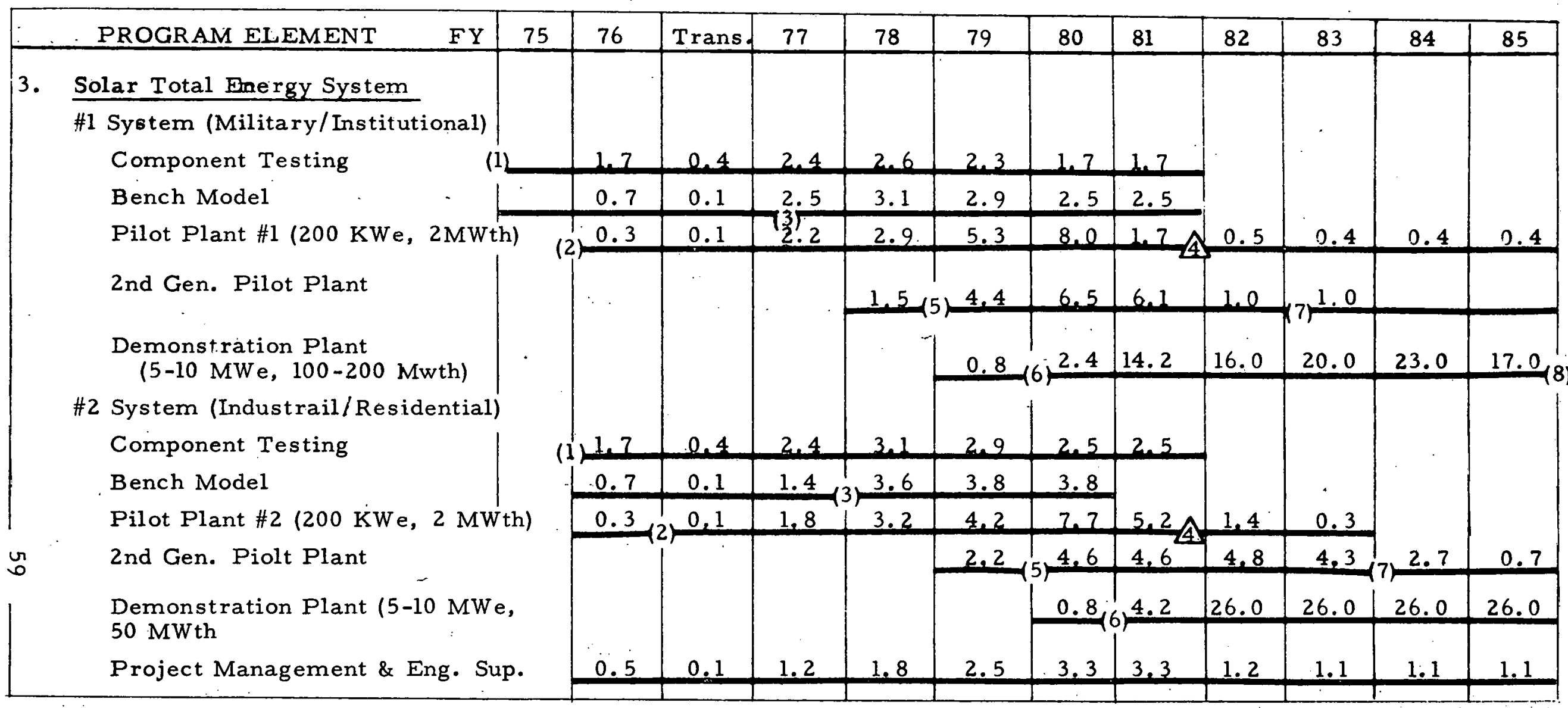

\section{Milestones}

(1) Decision to Build Bench Model/Test Facility

(2) Decision to Build Pilot Plant

(3) Bench Model/Facility in Operation

4 Pilot Plant Checked out and Operating
(5) Decision to Start Second Generation Pilot Plant

(6) Decision to Build Demonstration Plants

(7) Second Generation Plant in Operation

(8) Demonstration Plant in Operation 
TABLE _.. (Cont.)

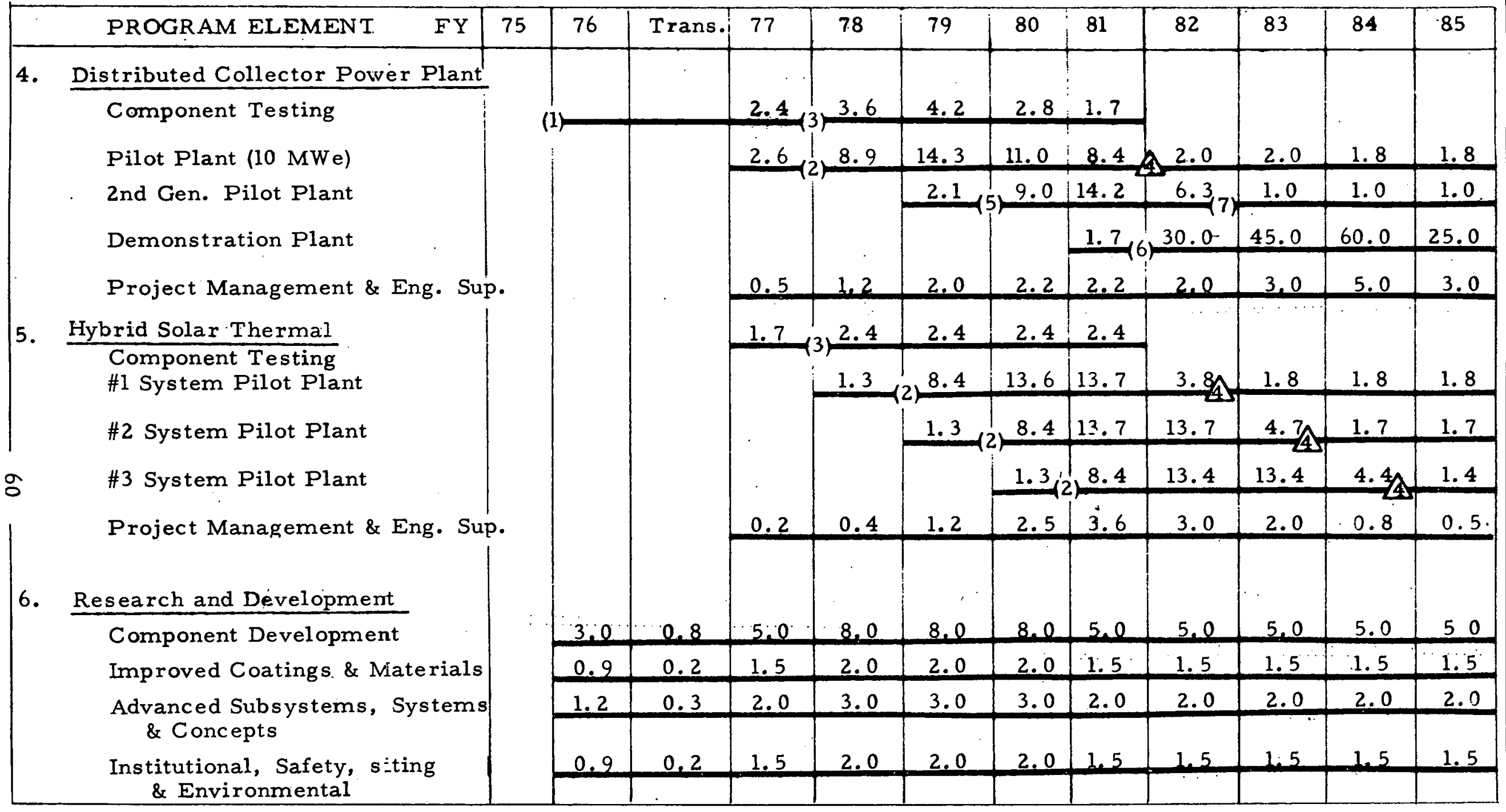

Milestones

(1) Decision to Build Bench Model/Test Facility

(2) Decision to Build Pilot Plant

(3) Bench Model/Facility in Operation

4 Pilot Plant Checked out and Operating
(5) Decision to Start Second Generation Pilot Plart

(6) Decision to Build Demonstration Plants

(7) Second Generation Plant in Operation

(8) Demonstration Plant in Operation 
TABLE IX (Cont.)

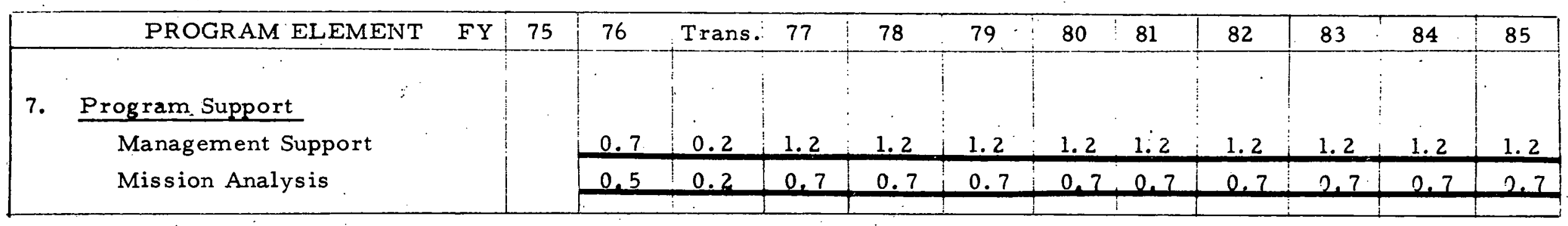

\section{Milestones}

(1) Decision to Build Bench Model/Test Facility

(2) Decision to Build Pilot Plant

(3) Bench Model/Facility in Operation

4 Pilot Plant Checked out and Operating
(5) Decision to Start Second Generation Pilot Plant

(6) Decision to Build Demonstration Plants

(7) Second Generation Plant in Operation

(8) Demonstration Plant in Operation

$\sigma$ 


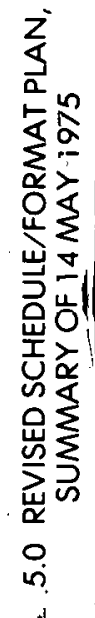


Section 5.0 consists of the reformatting and summarizing of the Solar Thermal Sub-Unit as requested by George Kaplan 13 May 1975. This implementation schedule reflects an extension from two to three year for the Pilot Plant. Preliminary Desigin and one year for the completion of the Solar Thermal Test Facility due to a delay in selection of the site for the Solar Thermal Test Facility. It is felt that the Basic Plan schedules for these projects are still attainable, though optimistic, and reflect the priority objectives for the Central Receiver Project and should be retained as part of the Program Planning. 


\section{Problems}

Technological

- No fundamental technological limitations identified to prevent substantial applications.

- Engineering and economical limitations may pose notable early risks to initial utilization.'

- Smooth integration into existing systems will require testing and demonstrations.

\section{Institutional}

- Owncrship, maintenance, and operational control of total energy systems by individuals or utilities must be resolved.

- Impact on utilities of large solar unit penetrations must be assessed in selecting preferred concepts.

- Volume production and tooling in industry will be required to achieve full economic potential.

- Site selection of early facilities must be consistent with long-term technical objectives and not parochial interests.

- State and regional regulation of public utility power networks must permit the use of a new technology.

\section{Clarification of Government Role}

- Government must support technology development and demonstration to reduce risk to acceptable commercial level and minimize schedule delay.

- Great public interest in solar energy will demand nearterm tangible progress.

- Government must coordinate and direct supporting technology for developmental efforts, i.e., NOAA for environmental data and NWC for technical support and test facilities. 


\section{Implementation}

- Initially, ERDA will fund industrial teams to develop and demonstrate the technical feasibility and indicate the economic attractiveness of solar thermal power plants and solar total energy systems.

- Utility participation is planned in all demonstration projects to accelerate widespread technology utilization

- Ultimately, industries and utilities will utilize the developed experiences and provide funding and direction for the commercial applications of solar thermal power plants and total energy systems.

- Continuing research and development studies covering collector/ surface coatings, high temperature material development, and solar thermal mission/system analysis are planned to keep the development efforts current with advanced engineering and economic applications.

- In-house government efforts will emphasize management of industrial $R \& D$ rather than initial internal systems/subsystem development with subsequent commercialization.

Parallel contracts awarded in 1975 for system concepts, preliminary design, subsystem hardware and testing, all leading to a $10 \mathrm{MWe}$ central receiver solar the rmal electric power pilot plant. Site selection; design, and construction of a $5 \mathrm{MWth}$ solar the rmal test facility. 1976-1977, interim capability late 1976, full capability mid 1978.

- Construction of a distributed collector test facility 1977--1978.

- Detail design completed 1978 for $10 \mathrm{MWe}$ central receiver pilot plant construrtion to start 1978.

.o Preliminary designs for total energy pilot plants to be initiated: 1977 - military and institutional applications 1978 - industrial and residential applications to determine economic feasibility of systems.

- Detail design of total energy pilot plants to be initiated in 1978 and 1979 with construction starting in 1979 and 1980 - to demonstrate operational, technical, and economic feasibility of the systems.

- Concurrent system, subsystem, materials, environmental, socioeconomic studies conducted to identify second generation concepts and address institutional is sues. 


\section{6-1979 (Continued)}

- Detail design of $10 \mathrm{MW}_{\mathrm{e}}$ distributed collector pilot plant to be initiated in 1978 with construction starting in 1979 .

- Preliminary designs for hybrid solar thermal systems initiated in 1977-1979: several concepts to be developed to establish relative feasibility of concepts.

$1980-1985$

- Construction of $10 \mathrm{MW}_{\mathrm{e}}$ central receiver pilot plant completed in 1981 and plant integration tests to utility grid started to establish operations techniques and economics.

- Detail design of $100 \mathrm{MW}_{\mathrm{e}}$ central receiver demonstration plant completed in 1982, construction started in 1983, industry/utility funding anticipated as much as $50 \%$.

- Continued testing of advanced hardware and components at test facilities.

- Detail design of solar total energy: demonstration plants initiated upon feasibility demonstration from pilot plant operation, anticipated in 1983-4 with industry/utility funding as much as $50 \%$.

- Detail designs of distributed collector demonstration power plant will be considered pending pilot plant operations and as the logical alternative to the central receiver power plant systems.

1985 and beyond

- Completion of demonstration plants - operational experience utilized in subsequent commercial plants.

- Successful demonstration plants to be employed in commercial operation - industry/utility acceptance of plant operation and capital obligations is anticipated. 
SOLAR THERMAL SUB-UNIT

\section{KEY MILESTONES}

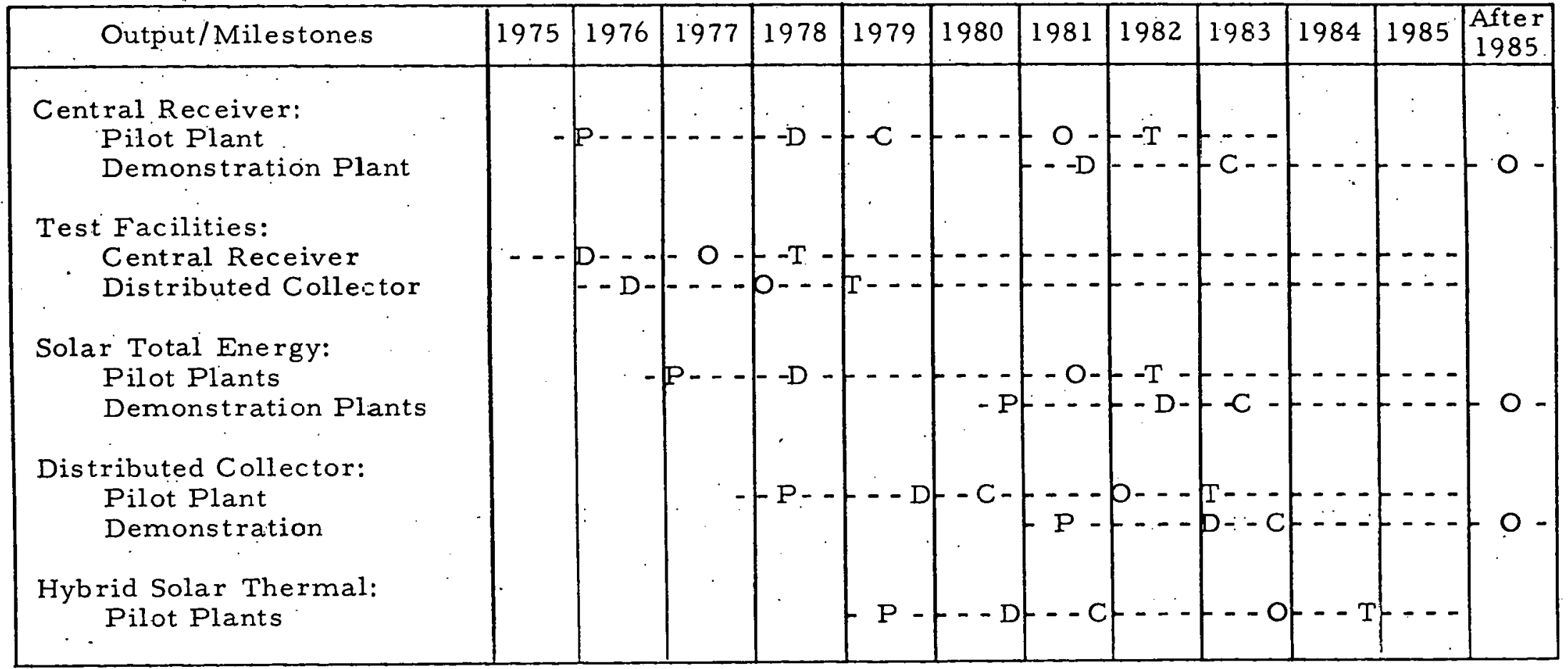

NOTES:
$P=$ Preliminary Design Started
$D=$ Detail Design Started
$\mathrm{C}=$ Construction Started
$\mathrm{O}=$ Operational, Construction Completed
$\mathrm{T}=$ Testing/Operations 


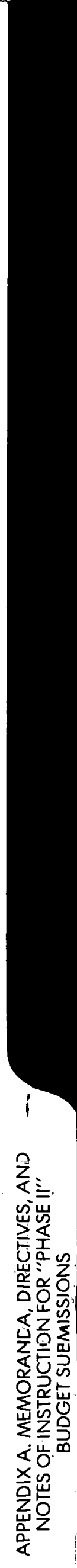


APPENDIX A

MEMORANDA, DIRECTIVES, AND NOTES OF INSTRUCTION

$$
\text { A-1 }
$$




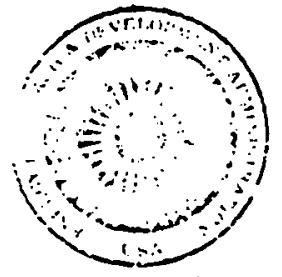

\section{UNITED STATES \\ ERERGY RESEARCH AND DEVELOPMENT ADMINISTRATION \\ WASHINETON, D.C. 20545}

March 6, 1975

MEMORANDLM

TO : Jerry Johnson (TRM)

Marty Sciloll (illtre)

Howard Webb (Aerospace)

FROM : Ted Mock Jad

SUBJECT: Responsibilities for "Phase 3" Solar Reports

I would like the members of the support team from TRW. MITRE, and AEROSPACE to take on the responsibility of preparing tine two "Phase 3" solar reports required for fina? submission by April 4, 1975. This effort will recuire close cooperation aniong all support team nembers and the members of ERDA's technical staff (who will have the authority for making final decisions on technica?, financial, and programmatic matiers).

Because of other pressing denands on ERDA program managers at this time, I will be looking primarily to you to satisfy the following reguirements:

1. 9:00 a.m., March 13,1975 - submission to me and to the cognizant ERDA program maragers of a prelininary draft of the "Phase 3 " reports. The primary purpose of this draft will be to assure that a meeting of the minds exists among support personnel, ERDA technical staff, and ERDA's Assistant Administrator for Planning and Analysis.

2. 2:00 p.m., March 21, 1975 - submission to me in 20 copies of a first draft of the "phase 3 "reports. This report should be as close to the final report as possible. It will be reviewed by Or. Teein, myself, and the appropriate members of the ERDA staff and returned to the support team by 11: GG a.m., March 25, 1975.

3. 2:00 p.m., April 3, 1975 - submission to me in 25 copies of the final draft of the "Phase 3 " report.

I realize that the time is short and the requirements tough -- but I have the highest confidence in your ability to meet the deadlines with a quality product.

I look forward with pleasure to working with you on this most challenging task. 


\section{Deadlines.}

1. First cut

2. Second cut

March 21

3. Final submission - April 3

\section{Format}

1. Summary description of program content (for each program unit)

2. Tabulation of five-year financial projections (FY 1977-1981)

a) Any revised estimates requested for FY 1976

b) Level of detail -- subprogram

3. Tabulation of program outputs/milestones and decision points

4. Projection of operating cost trends at multiprogram laboratories

a) Include Solar Energy Research Institute 
Objectiver

The objcitives desired for cach progran unit must be consistent ith the overall Elids objective(s) and the overali objective(s) of each prociali As.

A draft overall. staterent of ERDA goals ard guidance is erclosed as

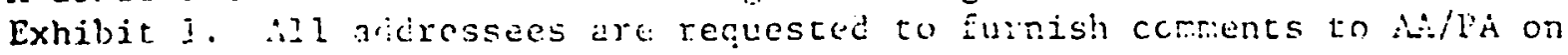
this statewire by the close of the first phase renoting ferica

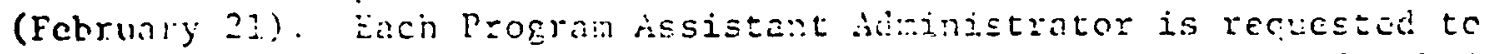

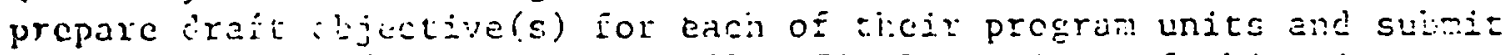
these also to isille by February 21. Tinal versions or cjjectives are to

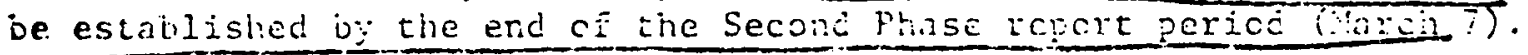

To assist in the prepziaticn o:: objectives, some sussesticns are encloscdias Exhilit 2 .

\section{Plan (Stratern)}

Each Proctar disistent Administrator should prepare a statident ci ro

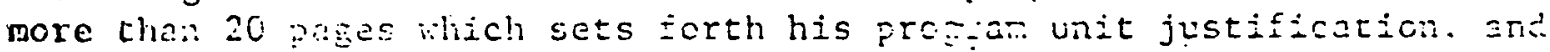

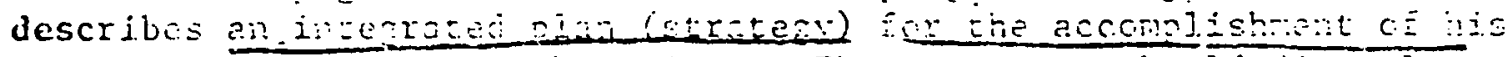

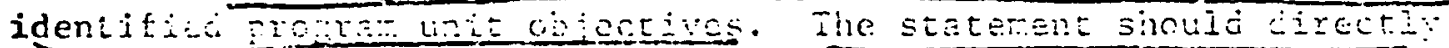

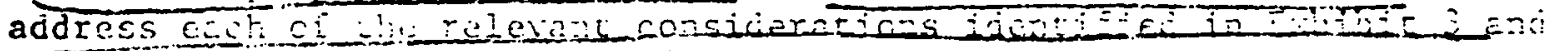

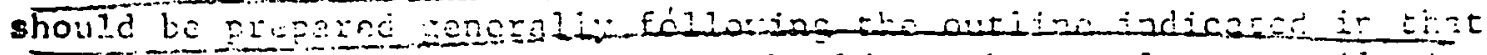

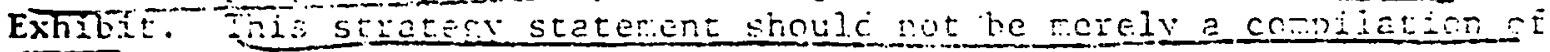

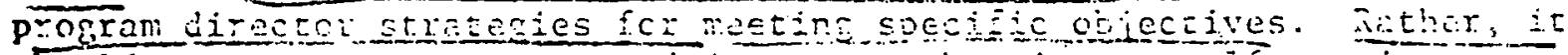

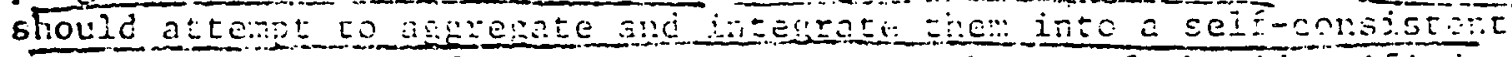

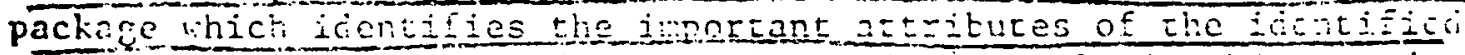

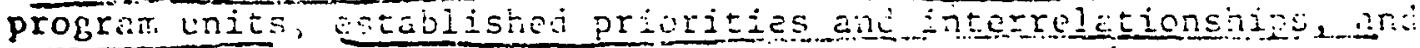
proposcs reai istje generic ariveacies to slipport tie choicen objectives and their attainebidity.

Features of the pros:ars rich vill specifically address how the objective is to be achieved should be included in the stratesy stitenert but macie independent of specific annual bucigets.

These stratcey statements will be aggregated and sumarized by Nil!

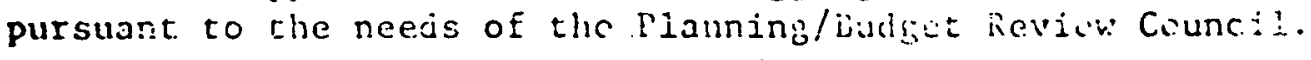

Draft plan writc-ups should be sumbitced to the $\mathrm{M} / \mathrm{l} / \mathrm{s}$ in the sacn! Phase riport (Yarch 7). AH/PA will comment on these prorint ly ce a.:cl: Assistant dirinistrator. Final plan wirte-ups are due in the thiri Phase repert (April 4 ). 


\section{Issuces}

It is expected that the preparation of objectives and the plans will gencrate several policy issucs wich will reçuje resolution at an carly date and prior to the bud:et reviev. Such issucs slouldi be identilici early in the planning, process and should be sutritte: to tie $A M / P A$ in the First Phase roport (February 21). 
HELPFUL HINTS FOK PRERIRING, OBJECTIVES

It is helpful in preparing oijectives to consider in order:

Role and Mission - Consider the responsibilities thrust upon you ly your position in the organization. What have you been assigned to do in relation to the agency's mission?

Succinctly statc ycur own mission.

Key Results Areas - Within your mission boundarics, what functions vill your organization perform? lhat will you be expecting them to do with their time and the budget dollars allocated to them?

\section{List these activity areas.}

Indicators - What will tell you whether or not your organization is performins as it should? What do you expect out of them? Are there"cvents" that will sisnal to you the progress being, made in your key results areas? Hould delays in reaching such events require your managerient attention?

\section{List those events.}

After proceeding through the above thought process, writing objectives is an easier tash. The objectives will become your directions for translacing activity into the proulletion of results that you want to satisfy your mission requirement. 
An objective is a statcment of results to be achicved. Anv endeavor

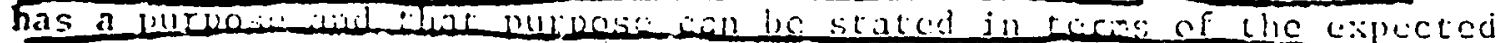
resuit - the objective.

All objectives have common features, such as:

1. They start with the word "to", followed by an accomplishment verb.

2. They spccify a single key result.

3. They specify a target date for the accomplishment.

4. They specify maximun cost factors that the responsible individual is willing to invest in the veriture.

5. They are as measurablc and verifiable as possible.

6. They do not attempt to specify "why" or "how" the objective is to be reached. (That is left to the plan.)

7. They relate directly to the accountable manger's roles and missions and to higher level roles and missinns.

8. They are realistic and attainable while stiil preseolios a chillenge.

9. They are readily understood by those who will be contributing to attainmenc.

10. They are consistent with resources! available and anticipated.

11. They avoid or minimize dual accountability for achievement when joint effort is required.

12. They are consistert with organizational policies and practices. 
I. To provide such technolngic and other support as is necessary to ensure the developaicit of worliable and acceptable processes necessary to a viable fuel cycle industry for nonbrecder reactors by at a cosi not to exceed $\$$

II. To develop and demonstrate a safe, reliable; and economically viable brecder renctor by at a cost not to exceed $\$$

Iil. To conduct the necessary research and development to demonstrate the technical feasibility of sustaining controlled fusion reactions by at a cost not to exceed $\$$

IV. To develop and demonstrate by at a cost not to exceed $\$$ an improved uraniua isotope separation process that would zeduce the cost of separative work by $\%$ 


\section{Strategi Considerations for Encrsv R\&D Prograns}

I. Estublishricnt of contcit.

A. Identification of the problem which the proposed R\&D or dennnstration will address.

B. Basis of the necd for Federal involvement*

C. Interrelationship with other encrsy R\&D or demonstration efforts undertation by EFDd, other Federal agencies, siate and local Government, U.S. industry, and other nations.

II. Specification of expected progran results (consistent with orjectives).
A. Nature and magnitude of contribution.
B. Timetable for achievinó results.
C. Economic targets and/or other specific program success criterla.
D. Remaining obstacles to commercial adoption.

III. Major technolosical aIternatives.

A. Nature of present state of developrent.

B. Nature of the technological hurdles which must be surmounted.

c. Limiting factors on the rate at which progress can be made.

D. Justification for deciding for commercial denonstration in the near-term, intermediate or long-term. .

E. Approach to be used in dealing with technical uncertainties.

IV. Identification of relevant external factors.
A. New authoritics, legislation, etc., which w1l be critical. to the ultimate success of program.
B. Government policies whose adoption, continuation, or revision will be critical to the ultimate success of profram.
C. Other parties who can affect program success.

Sec Scction 5.b.2., Federal Nonnuclear Encrgy RdD Act of 1974. ExHIHI\% 3 melosed as fippindix 
V. The economie, exviromentel and societal impacts and significance which the rrocosid steatesy ma have either during the conduct of the R\&D or the comercial adoptin of the tochnotogy.

VI. Management Approach

A. Basis for establishment of priorities.

B. Nature, quantity, and source of resources which are required.

C. Definitions of roles and responsibilities for ERnA and

U.S. industry (and other agencies or nations if appropriate).

D. Key decision points in fulfilling the objectives. 


\section{Enclosure II - Program Impiementation}

Each Assistant Administrator should sunmit by April 4 for his area of responsibility the following materials covering each of his program units: a summary description of program content; a tabulation of five-year financia? projections (FY 1977-1981) and any revised estimates requested for FY i976; a tabulation of program oucputs/mi iestones and decision points; and a projection of operating cost trends at multiprogram laboratories.

Guidance on content and format is provided below.

Program Description

Program narratives should be submitted for each program unit limited, on the average, to two pages, which summarize the objectives, the program justification, the program strategy and the approach taken in implementing program strategy to achieve objectives in the current planning year ard the outvears. The major portion of the text should stress the implementation item since the other materia? will appear in the longer strategy write-ups requested under Part i.

Outputs/Milestones and Decision Points

This is a multi-page tabulation for each program unit which categorizes key outputs or milestones under three time periods: near-term, mid-term and iongterm (Exhibit 1). These time periods are defined as the present through 1984 (near-term), 1985-2000 (mid-term), and beyond 2000 (1ong-term). Each program unit will normally have outputs or milestones which extend beyond the fiveyear financial projections. In addition, decision dates keyed to major policy or program choices should be identified in this tabulation. Total estimated costs for program units should àlso be included.

\section{Financial Projections}

Financiai projections should be submitted for program unit operating costs, equipment and construction and for operating cost trends at multiprogram facilities. Format guidance is given in Exhibits 2-6. It should be noted that the level of detaii for operating costs is the subcrogram (Exhibit 3 ).

Funds from other government agencies or industry should be iden! ified separately where applicable in the case of pass-through or jointly-funded programs (Exhibit 2).

Equipment projections should provide subtotals for "computers" and "other" equipment (Exhibit 4). The computer subtotal should include a listing of major computers (\$500,000 or over). 
Construction projections should include total dollar levels proposed and an individual listing of projects with a TEC of $\$ 5$ million or more (Exhibic 5 ). Fire, Safety, and Adequacy of Operations, Environmental, and OSHA requirements should be indicated. Sequential priority numbers should be assigned to new project requests.

Projections of operating costs and equipment, FY 1977-1981, should be in FY 1977 dollars. Suggested rates for escalating from FY 1976 to FY 1977 are as follows: Operating $8 \%$, Equipment $10 \%$. Submissions may use rates other than those suggested but in such cases must specify the particular escalation rates used and indicate the basis for the rates selected.

Since most construction estimates are prepared with currently available prices for material and labor, an allowance must be made to cover anticipated escalation for new projects. This is often computed to the mid-point of the construction period (as the average time of expenditure). In a more sophisticated analysis, escalation may be calculated separately to the mid-point of each specific obligational or costing period (either fiscal year or calendar year). Also escalation for a specific project may be computed from different material and labor rates, rather than using a composite rate.

Each office should determine the appropriate rates to be included for their iocation and specific types of construction projects. However, for your general guidance the Division of Construction prepared the following tabulation which gives their best estimate for future rates:

\section{Year}

Escalating from FY 1975 to FY 1976

Escalating from FY 1976 to FY 1977

Escalating from FY 1977 to FY 1978 and Beyond
Annual Construction Escalation Rate

10 to $12 \%$

8 to $12 \%$

5 to $8 \%$ 


\section{DIRECT SOLAR CONVERSION PROGRAM UNIT \\ PROGRAM ELEMENT SUMMARY SHEET}

Subprogram: Solar Thermal-4A

Project Index Number: $4 \mathrm{Al}$

Project Title: Central Receiver Project

Project Objective: Operation of a central receiver solar thermal commercial plant of 100-300 MWe (research, development, \& demonstration) must include these words

Project Justification:

Commercialization needs to be proven

Project Strategy:

- funding through industry by contract

- management by ERDA labs

Description of Task and Approach:

Major Results and Key Decision Dates:

$10 \mathrm{MWe}$ plant in operation $\quad 5$ May 79

Task Funding (1977 dollars):

Operating Expenses

Transition

FY75 Cong. Rev. Cong. Rev. 77 78 79 80 81 Completion

Capital Equipment

- Computers

Other Equipment

Plant Construction

* Pass - Through Funding

* Joint Funding (NASA, EPA, Industry)

*rough it if industry funding

TOTAL

Guidance on Pass - Through and Joint Funding:

* Statement explaining

Fire, Safety, and Other Requirements:

Prerequisite Program Subunit - Project Index: 
Wind

Divone

Solar thermal

Kaplan

Bloconversion

Bogan

Heating/cooling R\&D

Horowitz

Heating/cooling demonstration

Blieden

Agriculture

Cherry

Industrial. process

Doering

Photovoltaic

Magid

Ocean therma 1

Cohen

Meteorology/oceanology/insolation

Leech

Solar Energy Research Institute

Mock 
Program Unit

IV.

A.

B.

C.

D.

V.

A.

D.
Title

OIRECT SOLAR CONVERSICN

Heating and Cooling of Buildings

Agricultural and Process Heat

Bioconversion to Fuels

Technology Utilization

SOLAR ELECTRIC APPLICATIONS

Solar. Thermal

Photovoltaic Research

Wind Energy Conversion

Ocean Thermal Energy Conversion 
U. S. EMERGY RESEARCH AND DFVELOPULET ADMTNISTRATION

Total ist.

Cost ihrough

Completion

(villions of

Dollars)

Program Unit Ticle

List Major Results ${ }^{a}$

Decisions Points Anticlpatect

[EXAIIPLE:]

Decision Points Antic:pated

Deciston to build a pilot plant: selection made from competing approaches: bbls of oil or equ:valent)

$x(1979)$

\section{Major Results Expected}

Operation of a demonstration plant ( quiving or __ bbls of ofl or 
U. S. ENERGY RESEARCI AND DEJEJ OPMENT ATMINJSTRATION

EXHIBIT 2

PROGRAM YROJECTIONS SUMMARY

[FORMAT]

(Dollars in Mtllions)

PROGRAM UNIT TITLE

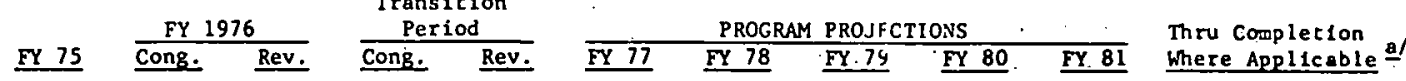

\section{Operating Expenses}

Capital Equiprent

Plan

Totai [Program Unit T1tle]

FUNDS FROM OTHERS (not added to ERDA total)

Finds from other azencles and industry: pass thru and joint programs.

Other Agency $A$

Industry $\mathrm{C}$

Total [Program Unit Title] Fands From

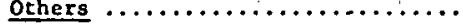

a/ Where available, provide in a footnote the basis for cost estimate. 


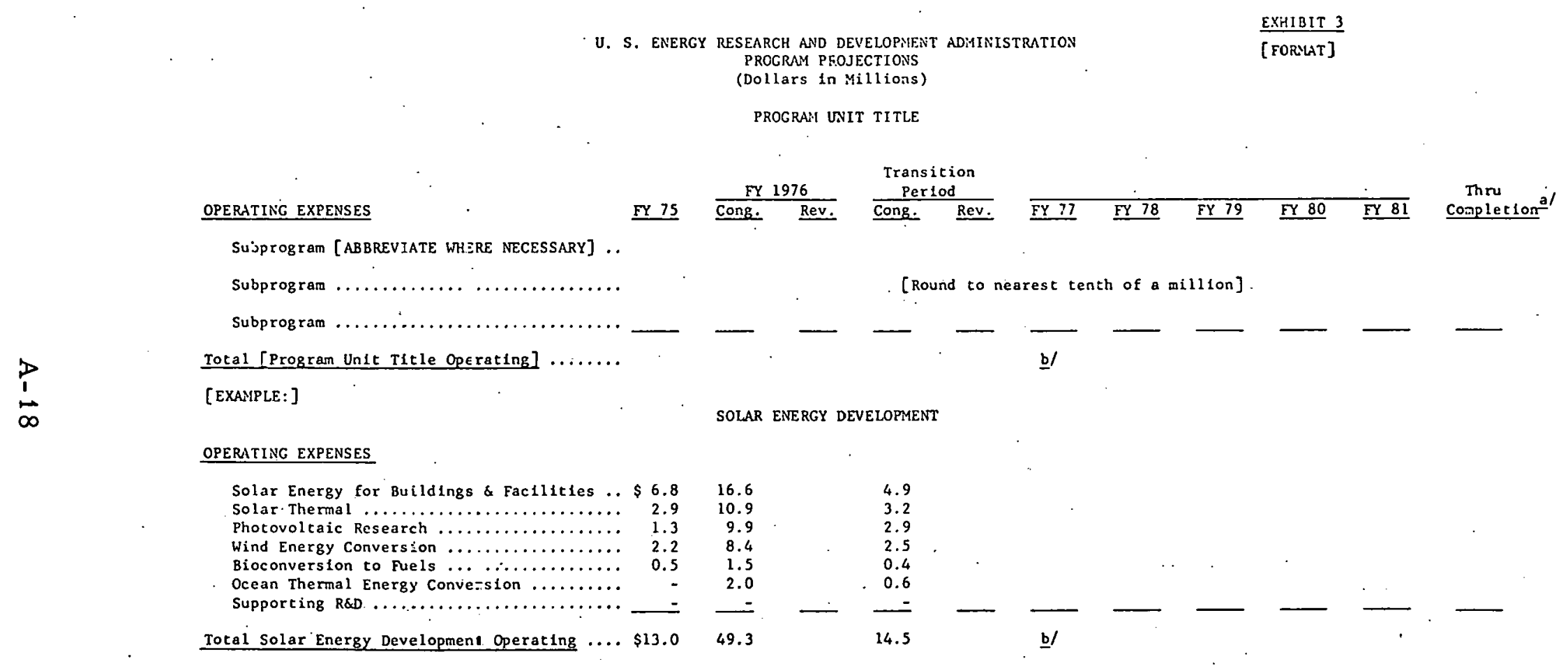

af where available, provide in a footnote the basis for cost estimate. b/ Escalation factor. $\%$, FY 1976 to 1977. 
PROGRAM PROJECTIONS (Cone'd) PROGRAM UNIT TITLE (CONE'd)

\section{CAPITAL EQUI PAENT (BUDGET AUTHORITY) Computere \\ L1st major computera ( $\$ \$ 00,000$ and over). \\ otter computers \\ Total computers ................. \\ Other Equipment}

Total [Program Unit Title Equipment] ........

\section{[EXATLE:]}

PROCRAM ProJECTIONS (Cont'd)

PROGRAM UNIT TITLE (Cont'd)

\section{CAPITAL EQUIPMENT (BUDGET AUTHOEITY)}

ABC Model, NAL $\ldots \ldots \ldots \ldots \ldots \ldots \ldots \ldots$

XYZ Model, ENL

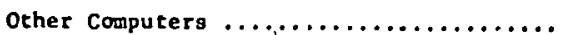

Total Computers

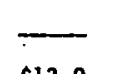

Other Equipment

Total [Program Un1t T1tle] Equiprent
(Dollare in Mllilons)

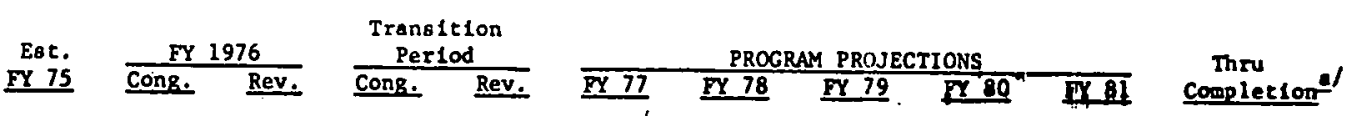

EXHIDIT

[FORMT]

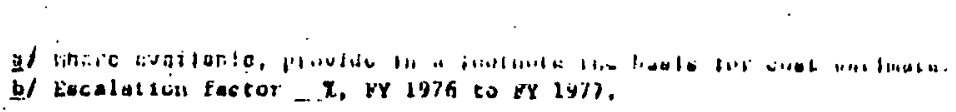

[Round to nearest tenth of a m1111on]

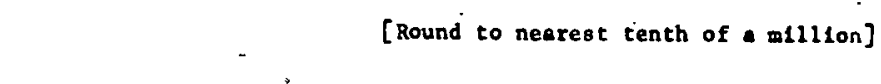

b/
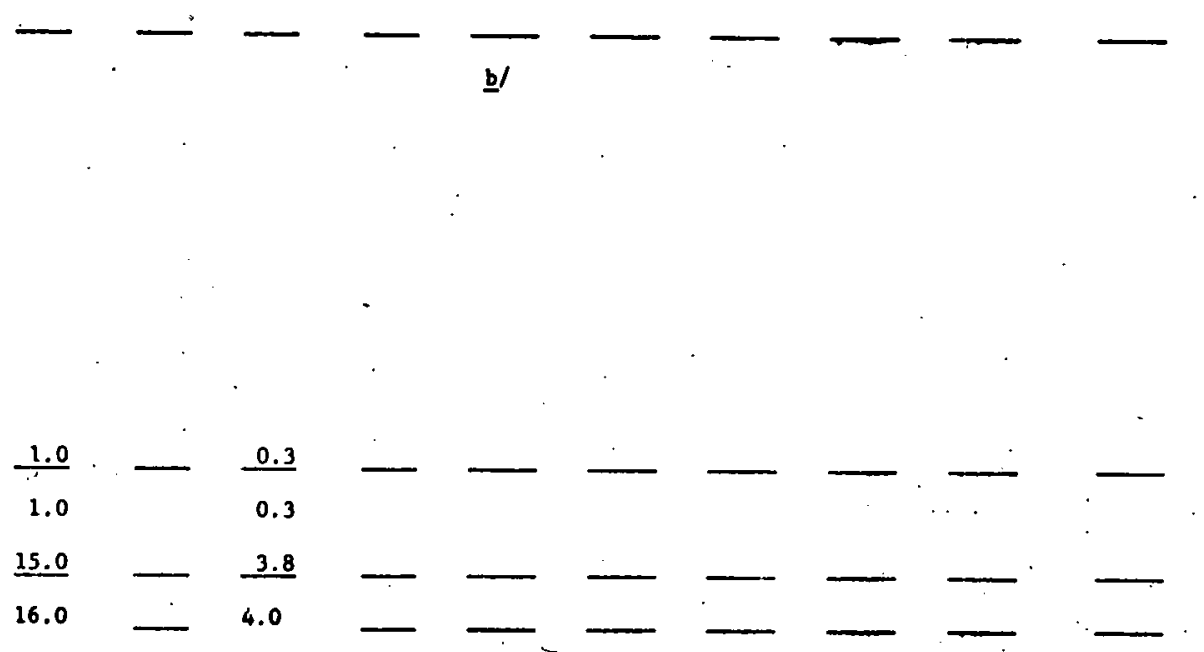


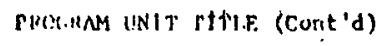

PLANT (BUDGET AUUTHONITY)

Authorized Profests

74-1-3 title, loceation (App. thru FY 75 ; FY $76, \ldots \ldots \ldots \ldots \ldots \ldots \ldots \ldots \ldots \ldots \ldots$

General Plant Projects (FY $75 ;$ FY 76 )...

New Profects

Title, loeation (Note if FSAOC, Environmental, or CSHA requititement) $\ldots \ldots \ldots \ldots \ldots \ldots \ldots \ldots$.

Total[Program Unit Title] Plant.

[Fonient?

EC $\quad$ FY 1976 Transition

[EXATPLE]

PROGRAM PROJECTIONS (Cont' $d$ )

FUSION POWER RESEARCH AND DEVELOBMENT (CONE'd)

PLANT (BUDGET AUTHOFITY)

Auchorized Projects

73-x-x bire factelry facll1ty, 9NL (APp. thro

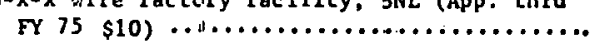
General plant Prédects (FY 75 \$0.5 million) ...

6.0

New Projects [nurbered by prio=1ty order]

1. Tckanak fuston test reacror (A-E and

2. Cable facilley upgrading: PNL $\ldots \ldots \ldots \ldots$

3. Bottle-fusion factlity, MIT

4. Exerc1se ring, ANL

[Round to nearest tench of inl1110n]

Total Pugion Power Reg.

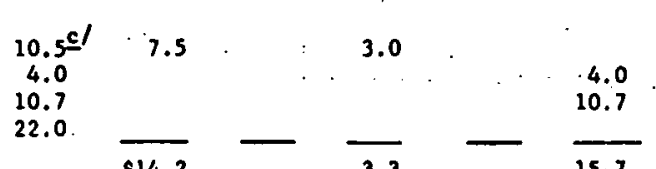

1.0
4.0
$\frac{10.7}{15.7}$

1.0

.1 .0

1.0

1.0

2/ Where avaliable, provide in a Enotnote the basis for cost estimate.

b/ Escalation factors over the perdod of the construction schedule used in estimating TEC are as follows:
c/ Excludes $\$ 400,000$ CPSD. 
U. S. ENERGY RESEARCH AND DEVELOPMENT ADMINISTZATION PROJECTED OPERATING COST TRENDS AT MULTIPROGRAM LABORATORIES (Dollars in Millions)

PROGRAM UNIT TITLE

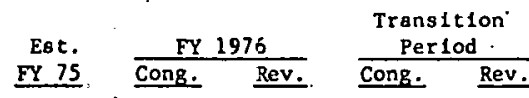

EXHI3IT 6

[FORMAT]

Argonne National Laboratory

Brookhaven National Laborato:y

Lawrence Berkeley Laboratory

Lawrence Livermore Laborator:

[Round to nearest tenth of a willion]

Los Alamos Sçientific Laboratory Holifield National Laboratory

Pacific Northwest Laboratory

Sandia Laboratories 


\section{1 mis}

program Manager

Solar and Goothermal

FISCNI IMAR 76 ERUTPNENI' BUDGET

Ir. I'eem has requested tilat an -quipment budget be developed for FY 76 .

There is attacined an infomal definition of capjtal exuiprant as it partajns to the separate apromiation ir. E⿺辶A. Your informal input as to pribable ry 76 expipient regulirenents, using these guidelines, will ba aprrecialed as snon as possivle. please identify insofar as possible, types of expuipnent itons and contractor, facility, or project for which needed.

It is suggested that for this purpose a joweral interpretation bo used

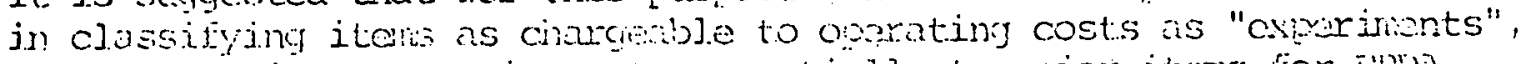

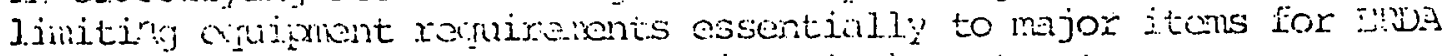
lidromatories anc off-site (nor-university) contractor uses.

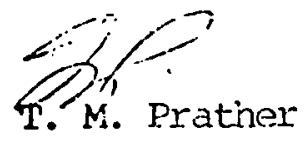


CAPITAL EQUIPIITNT

Capital equipment funds are used when the cost of the item is capitalized as an asset in the ERDA accounts. (Exception-Equipment purchased as part of a construction line item). The basic definition is that the item have: (a) an initial cost of $\$ 500$ or more; and, (b) an expected useful life of one year or nore.

The first of these is self-explanatory. The second, however, is subject to interpretaivion as to the type of useful life, with a distinction to be made bottiean items for experimental use as opposed to those for general use. Clevrly, ejuipinent iteins for general or multi-purpose use at a Government owned laboratory are always capitalized. Similarly, items of this type purchasexi for use in an off-site contract effort are capitalized unless a separate decisioil is made for title to vest in the contractor. (Legal bisis is available to usually vest title in educational institutions but not in private contractors or other Govemiant agercies). Conveisely, equipment type items for one-tine use as convonents of an experiniental device clearly are not to be capitalized and are chargeable to operating funcis. In between these obvious evamiples is a grey area in which a decision on the type of funds is made on the basis of the particular ciucumitinces jnvolvar. Factors in this decision include: (a) probuble u].timte lccation and dimosition of. the itoms; and, (b) extent of useful life diart fron the exparinental use. Incidentally, the onestion

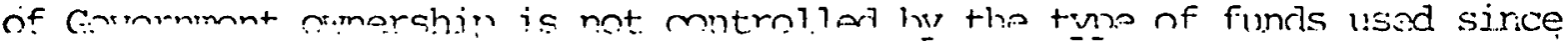

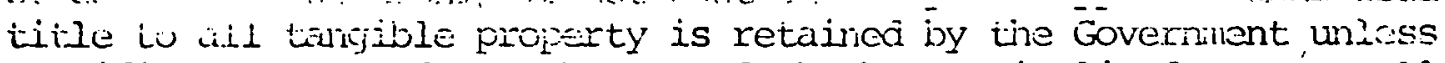
specifically granted elsewhere, and whether capitalized or not. ilso incidentally, the final decision on capitalization and therefore type of funds is an accounting decision but based extensively on program guidarce. 


\section{UNITED STATES \\ ENERGY RESEARCH AND DEVELOPRENT ADMINISTRATION \\ WASHINGTON, D.C. 20545}

March 19, 1975

MEMORAND!IM

TO : All Members of the Solar Energy Task Force.

FROM: Ted Mock $/ E$ ' $m$

It appears that we will be able to negotiate a contract with the National Academy of Sciences by Afril $i$, 1975, to carry out a study to he1p define the role, imission, organizationai structure, and site selection criteria for the Solar Energy Research Institute.

Members of the NAS staif have reauested the following types of material in order to prepare for the first meeting of the NAS study cormittee:

- Sumiary of our current and past solar energy prograns complete with descriptions of the research being carried out, funcing levels, and project personnel.

- A list and/ur description of existing and planned research (and development) facilities with their associated manpower and funding leveis.

- A. list of solar energy research organizations (universities, industrí etc.) experts, and reports.

- A list of solar energy riewsletters, and other publications.

I. am not expecting anyone to sit down and come up with new istirgs or prowait: descriptions. What I am looking for is simiply material which you may have in your files or on your sheives.

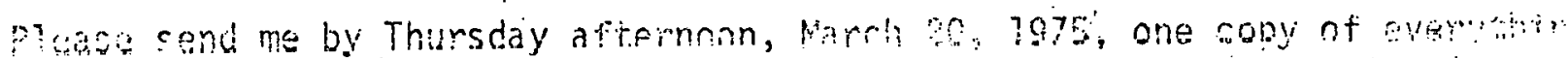
"ul' 'uy have available. If you have only one copy of any docment.

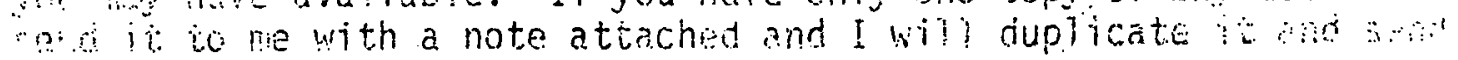

: ? och to you immediate!y.

$$
\text { - ur belo. }
$$




\section{UNITED STATES \\ ENERGY RESEARCH AND DEVELOPMENT ADIANISTRATION \\ WASHINGTON, O.C. 20545}

March 21, 1975

Director, Division of:

Solar Energy

Geothermal Energy

Physical Research

Controlled Thermonuclear Research

CALL FOR AGENCY PLANNING AND BUDGETING INFORMATION

In a memorandum dated February 7, 1975, on the above subject, the Controller and the Assistant Adninistrator for Planning and Analysis provided a schedule for submission of certain material to be used in the following docunents:

1. A National Comprehenslve Energy R\&D Plan.

2. A Federal Comprehensive Energy R $\& D$ Program Inplementation.

The Phase 3 Response under this schedule is due on Apr11 4, 1975, and con8 ists of final draft strategies and Program Implementation detail.

In a meeting of the Senior Staff Planning Group held on March 20, 1975, chalred by Richard $M$. Pastore, further instructions were provided for the preparation of the Phase 3 Response. The following paragraphs and the attachments to this memorandun summarize these instructions.

STRATEGY - In the opinion of Plans and Analysis, the March 7, 1975, submissions on the first draft strategy were satisfactory as regards "what" is to be done under each program unit. However, they were not satisfactory as regards "why" the work is being done. Hence, we are required to provide answers to the set of eight questions posed on the attached sheet. Please prepare for your program unit(s) a brief response to each question. I need to have your written answers to these questions by noon on March 27 , 1975, so that I can assemble the composite response for Dr. Teeil's re= view prior to April 4, 1975.

PROGRAM IMIPLEMENTATION - The detailed schedule for the Program Implementation Is attached. The AA/Solar, Geothermal, and Advanced Energy Systems submission must be made on April 4, 1975. A set of "General Instructions for Preparation of Materlal for Program Unit Descriptions" was distributed in the March 20

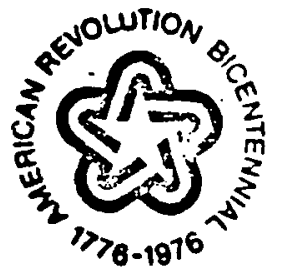




\title{
$-2-$
}

meeting. Please compare these instructions (see sttachment) with the Program Implementation drafts that you prepared for Dr. Teem for March 21, 1975, and make any necessary revisions to format or content.

\author{
Gerge K. Hess g. \\ George $\mathrm{K}$. Hess $\mathrm{Jr}$. \\ AA/SGAES Representative \\ to the Senior Staff \\ Planning Group
}

Enclosures :

as stated above

cc: Dr. J. Teem 


\section{Questions}

1. To which of the nine Hational Energy R\&D Goals are the Program Units urder your control responsive?

2. What l:ey words or phrases characterize the dominant problears and/or. constraints that are associated with your contribution in the attalnment of those goals? Answer in relation to the Program Unitis for wich you are responsible.

3. What can the Government do to help industry solve or alleviate these probleins by:

- Time?

- Quantity output?

. Cost?

4. What Government/industry relationships would provide that help? inhy?

5. What measurable indicators vould prove to you that procerss is being riade toward the resolution of stated problems?

- Econonic.

- Technical.

- Institutional (including political, social, and legal).

- Environriental.

6. How can these indicators be made meaningful in a public form?

7. What near, mid, and long-tern objectives are derived from tisese indicators?

8. How do the cmphases which you vill apply to persue these vijetivns vary over time to satisfy the National goajs?. Why? 
NATIONAL ENERGY $R \& D$ GOALS.

I. Expand the domestic supply of economically recoverable energy producing raw materials.

II. Increase the utilization of essentially inexhaustible domestic energy resources.

III. Efficlently transform fuel resources into more desirable forms.

IV. Increase the efficlency and rellability of the processes used in the energy conversion and delivery systems.

v. Trans form consumption patterns and improve energy utilization.

VI. Increase end use efficiency.

VII. Protect and enhance the general health, safety, welfare and environment related to energy.

vIII. Perform basic and supporting research and technical services related to energy.

IX. Improve management effectiveness throughout the energy system.

X. Administer the ERDA operations efficiently, rellably and safely.

XI. Provide the nuclear related support for the maintenance of a viable defense establishment. 


\section{PROGRAII MPLEHENTATIO: SCHEDULE}

April 4

April 7-11

Apri1 7-11

Apri1 8-14

April 15

April 16.

Apri1 17.

April 18

April 21

April 22

April 23

April 24

April 25

April 28

April 29-ilay 2

May 5-9

May 12-14

May 13-15

May 16

May 19-20

May 21

May 22-26

May 23-27

May 28-29

May 30

June 2-27

June 13

June $16-17$

June 18

June 19

June 20

June 23
Phase III Submissions from MAs

$\emptyset$ III Revier and Critique

Revise $\emptyset$ III Recycle and Consolidate

Type and Proof

Reproduction

First Draft to SSPG

Recomnenclation on prioritias (SSIG)

$\emptyset$ III Revicwed, Formulate SșPG Guidance

Guidance to SSPG (Implcmentation Detail)

First draft Comments - Iniplementatica Detail.

Incorporate SSPG Revision - Implementation Detafl

Type and proof - Second Draft Iriplcinentation Detail

Reproduction - Second Draft Inp] enentation Letail

Program Implementation Submittal

P/DRC liember Reviev

Formal P/BRC Neeting and Reviev (Final Plan and Report)

Incorporate P/BRC Revisions

Type and Proof

Reproduce Final Plan and Froj:an Implementation Reports

Coordinate Final with $P / B R C$ and $D / A$

Final Plan and Report Submittal to ERDA Adininistrator

Incorporate $\Lambda$ dministrator Revisions

Type and Proof

Reproduction

Submit to $O N B$

ONBS Revien

ONB Comnents

Incorporate OMB Revisions

Type and Proof

Reproduction

Submit to Administrators

Incorporate-Auministrators' Changes 
June $24 \quad$ Reproduction

June 25 Submission to OMB

June 30 Submission to Congress 


\section{General Instructions for Preparation of Material \\ For \\ Progran Unit Descriptions}

1. The program unit description is a summary statement of the program unit objective and strategy, and the progran implementation. The intent is to provide a concise, factual description of program content and the specifics of the approach taken to assure successful achievenent of planned results in the near term, mid term and long term periods of the plan.

2. Program unit objectives and strategy are treated more fully in the strategy plan; they are sumarized in the program unit description to provide a "stand alone" document. The narrative will deal mostly with the implementation: the characterization of the research, development, demonstration or other attributes of the progran and the logic of program design, , i.e., the actions, decisions, resource commitments and other arrangements to achieve the results contemplated by the program stratcgy.

3. The program unit descriptions vill be included in a document along vith the sub-program unit outputs and five-year planning projections.

4. The program unit description should provide adequate explanatory detail for unierstanding the program outputs and cost projections considered in the budget and planning review process.

\section{Length and Format}

5. Because some program units may have five or inore subunits, or may be more complex than others, precise space allocations are not possible at this time. However, program unit descriptions should be limited to two pages, on the average.

6. The April 4 sutmission should be in "Prestige Elite" type, on legal-size sheets (8-1/2"x 14") in accordance with the format in Exinibit 1 and submitted as an original and two Xeroxed copies (the latter will be used for a preliminary markup of Planning and Analysis coments and will be returned to contributors for appropriate revisions prior to assembling the complete draft).

7. Some descriptive flexibility geared to the particular characteristics of operating programs and projects is desirable and expected. In general, however, the narrative will provide a lead statement for the program unit and descriptive detail for subunits following the generic outline below and format guidance provided in Exhibit 1.

\section{a. Lead Statement for Program Unit}

This is a concise statenent of the program unit objective and the program unit goal orientation and strategy. 


\section{b. Subunit Inplementatinn}

This is a brief narrative for each program subunit, describing specific milestones and outputs, and assumptions -- including costs, timing, decision points -- and other salient features of implementation. (See format guidance in Exhibit 1 and 2 ).

\section{General Criteria}

8. The content of initial program descriptions, due on April 4, should satisfy the following general criteria:

a. Descriptions should be well organized to reveal the logic of program design and the key actions and decision points for managing the successful achievement of research, development and other objectives.

b. Economic, technological, environmental, social or other merits of the program should be described objectively as possible, and supported by quantitative data as appropriate.

c. The total estimated costs of major proposals should be identified.

d. Key assumptions and constraints which underly the scope and design of the sequence of the implementing actions - including costs, tinin: outputs, and institutional or other arrangements. -- should be identificd and the implications made clear.

e. Coordination with other federal agencies and the private sector and the degree of financial participation by fEderal agencies and industry should be emphasized where appropriate.

f. The relationship of the proposed program to any Federal national energy or fuel policies should be identified.

g. Near tcrm activities and costs should be reiated to longer term objectives and costs. The rationale for the degrea of emphasis given to activities in the various time periods should be oxplained.

9. In the preparation of copy, the following standards will apply:

a. Material should be written in a language understandable to an intelligent "lay" reader. Technical detail should be mininized. The focus should be on matters of broad significance to the public intarest, including how the program implenentation dcals with problens, risks and uncertainties.

b. Care must be yiven the choice of certain words in order to convey their intenced meaning. (e.g., "comnercialization" of technolosy -.. if this is meant to identify a timed result, it should be clear to 
the reader whether this is an initial step in tile process or whether it signifies the time of significant impact on the solution of an energy problcm) Similarly, care should be excrcised in using terms such as feasibility, demonstration, requirements, needs, etc.

c. Statistical material should be briefly sumarized in the narrative. One or two brief, simple table may be included, as appropriate.

d. Names of ERDA laboratories, sites, key contractors, and uther public or private contractors or organizations should be included in the text when they represent a capability committed to a significant aspect of the program, or represent entities with whom integrated planning relationships are established.

e. ERDA internal organization names. should be used only if necessary to put an item in perspective.

f. Language should reflect a fresh ERDA point of view and not the reports and documents of previous agencies.

\section{Schedule}

10. The drait program unit descriptions must be submitted to the APA no later than April 4. 'This timing provides little flexibility for final preparation of the complete program package wich is to be submitted to the P/BRC by April 28. Thus, submission of carly drifts prior to the April 4 due date is encouraged. 
Provide a conclse gumary of the program unit objective and etrategy. There may be a sepate objective for each tine period of the plan-neer term (thru 1984), wid term (1985-2000), and long tera (beyond 2000).

\section{Brogram Subunit Name (repeat for each subunit)}

\section{Qutput}

Spectfy the output for this subunit.

\section{Assumptions}

Identify any key assumptions which underlle or sonstrain the program implementation. Include those matters which may be uncertaln but which are taken to be true for purposes of program design. Assumptions may include estimates of: avallabllity of manpower or other resource constraints; supply and demand forecasts; probabllities of technlcal success and publlc acceptance; federal agency and private Industry roles; cost sharing, etc. Program Implementation should be sensitive to the eccuracy of these assumptions. The $\log 1 \mathrm{c}$ of the Implementing actions may include reducing the uncertalnty of assumptions or mintrizing the risks involved.

\section{Implementation}

Highlight the major elements of program subunit implementation. The narrative should reveal the logic of the planning and the spectfic actlons to achleve planned outputs. Include sdequste derall for understanding subunit outputs and cost projectlons. Stress the factual content -- what, when, who, how much -. the context is already provided by the preceding material. Crosereference ma be made to other parts of the program unit document (c.g., the program outpue tabulation or financial projectiona). a eppropriate. Further gildance is provided in the General Instructions.

Mejor changee from last year' agency budget request (President's budget to Congress) proposed for FY 1976 or FY 1977 abould. identify any elgnificant impete on resource requirements and/or resulte over the oucceeding four yeare. 
Instructions. for Preparation of Material

for Program Outputs/Milestones

\section{General}

The program outputs for all ERDA programs are to be presented by subprograms according to Exhibit 2. The combination of milestones and decision points should lead logically to one output identified with completion of each subprogram. More than one output may be meaningful (see glossary). The description of the relation between subprograms, subprogram outputs and program objectives should be presented under Program Unit Description. The complete description of each milestone, decision and output for a subprogram should be contained In this section and should follow the guidance given in the glossary. The program managers are responsible for these descriptions with consultative guidance to be provided by the NA's.planning staffs and APA.

Each subprogram should show a direct relation between its oucput (especially the program completion aspect) and the program unit objective for that time period. The program objectives in the near, mid or long term are supportable only by subprogram outputs. Milestoncs should thus be directed toward subprogram output as these are most meaningful in terms of completing the subprogram, which then provides the basis for Judgment that program objectives have been met. This vill avoid heavily qualified or partial objectives being targeted for programs and will rather emphasize the more productive, final results. 


\section{Glossary of Terms}

An Output is defined as the completed task of a subprogram unit. For research subprograms the output may be a level of investigative activity that is targeted and reached.At the other end of the output spectrum, a manufacturing oriented subprogram, the number of fuel cells, kilograms of material or other unit quantities vould be outpit. These manufacturing tasks would be completed each year and measured against their targets or schedules. For more development oriented subprograms, the completion of one R\&D approach as evidenced by successful or unsuccessful operation of equipment or prototype demonstration plants would be typical output.

Subprogram outputs and nilestones should be defined so that they are either directly relatable to dollars and manpower projections 1 / or supported with accompanying background information which indicates the relation between these results and the subprogram projections of funds and manpower.

Milestones may be defined as key accorplishments or plateaus of performance level. They are measurable interim steps to achieve subprogran output. Examples are: cumpleted preparation for a choice of technology where more than one approach exists; laboratory scale pilot operation of key hardware; pilot plant or demonstration plant operation at targeted levels; and proof-of-principle or empirical evidence for. research hypotheses.

I/ Ianpowar data will be requested for each subprogram durin: the na:t year. APA analysts will be contacting the plaming staff of program Assistant Aduinistrators to prepare these projections. 
Dectsions described under program outputs should be those involving critical choises for subprogram direction, such as choice of technology; dectsions to proceed along several approaches rather than one; decisions to accelerate funding and shorten the time between interim subprogram steps; or any najor.change in plans for a subprogram.

\section{Subprogran Unit Enphasis}

The emphasis for program implementation to be used in the annual planning cycle will be on subprogram units. These units are large enough organizationally to be funded and managed separately and sinall enough to have clearly measurable results. The subprogram unit nanagers will have prior agreement through the Assistant Adninisirators on the planned results by which his progress can be measured. These results will be defined (and revised as necessary) by the subprogram and program manager in consultation with the $\mathrm{AA}^{\prime}$ \& planning staffs and reviewing by APA as action plans each year during the planning, cycle. APA interests will be principally overview with respect to progran unit objectives and general planning strategy. The purpose of such specific planning is two-fold, to provide the Administrator vith clcar, measurable progress plans and the program and subprogram unit nanagers with specifically approved targets and direction. Many of the subprograms are not amenable to precisely defined direction, but do have planning indicators availisle through targetable performance levels. These subprograns may require efforts to develop unique planning rationale, but they should adhere as closely as possible to this guidance. 
U. S. ELERCY RESEARCH AND DEVELOFIENT ADMINISTRATION PROGRAM OUTPUTS

[1 paga mintaum for cach subprogram]

\section{Program Unit Title}

Subpregram Unit Title

Identify criteria for subprogram corapletion or target activity level

$$
\text { Manpower }{ }^{-}
$$

L1st Major Resuits

Decisions Polnts Aaticipated

Milestones/Output

[EXAMPLE:]

Manpower

Decisions Points Anticipated

Declston to build a pilot plant; selection made from competing approaches (refer to
competing approaches: $\mathrm{a} / \mathrm{MW}$ or competing approaches.
of oil or equivalent

Major_Rrsults Expected

operation of a demonstration plant.

a bis or bols of oll or equivalent.

Subprogram Outret

Successful transfer and operation by private industry of all ticcessary technology.

Total Est.

Cost Through

Completion

1975

1980

1985

(TEC) plant start 2987.
Peak: 1500 professional Average: l.100 professional

………둔

[ POR:Li]

Reduced fo: Purpose of Call only

"lse 8h" x 14" papcr for subntssicis.

Allow a 15 space left margin

(elite type)

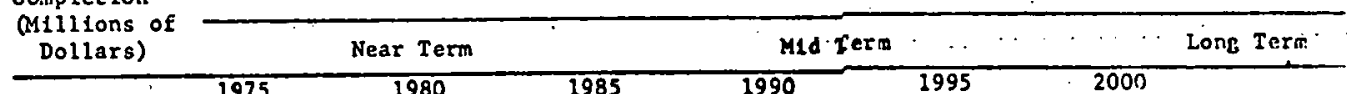

1990

1995

2000

Energy supply contribution of

Ident Ify approximate dates when resules (use 0 ) are expected or decisions (use $x$ ) required - $c .8$., ERoh domo plant start 1981, fuli scale joint industry/ERDA

\author{
Peak: $30 \%$ incroase. \\ professiona
}

Peak: Fewer $t \sin$ ! mid-tcrer. approacl i::
zero by 26

a Potential total impnet of dectsiun or result in terms of possible energy supplied.

of and relative changes for the next two perlods. 
OUTLINE OF WEETING WITH SENIOR PLANNING GROUP - YAY 13, 1975

. 1. Outcome of P/BRC Meetings, May 5-9

- Consensus on General Methodologies for presenting:

- The energy problem and its ramifications

- The domestic resource base and its uncertainties

- The possible responses to the problems that form goals

- The probable contribution of key technologits (scenarios)

- The messages that result from studying scenarios

- The problens with the key technologies and the role of supporting technologics

- The need for program design that addresses the identified problems

- The role of the Federal Government as determined from program design

- A Budget Mark

2. Outcome of $A P A / O C$ Work on $A A$ submissions

- Reduced versions of technology descriptions in Plan - Chapter 2

- Strawman objectives and Program Strategies in Plan - Chapter 6

- Reduced versions of Program Implenentation - Vols. I. and II for volume reduction and clarity

3. Projected APA/OC work:

- Rewrite Plan generally along lines of APA presentations at P/BRC mecting

- Prepare budget tables in accordance with marks on May 9

- OC prepare supplemental request

- Rewrite Program implementation to agree with Plan a budget mark: PI to address:

- Program unit (technology) objectives 
- Designation of sub-program priorities.

- Identification of major technologles problems, institutional problems

- Clarification of Government role

- Description of activities that attack problems to achieve objectives

- Key milestones

4. Projected $A A$ work

- Rework financial tables per marik up - primarily OC

- Revise technology description for Plan - Chapter 2

- Revise Objectives and Program Strategies for Plan - Chapter 6

- Revise Program Implementation pages for Volume II

(Note: the last three tasks should be accomplished simultaneously since the material. in duplicative in Plan and Program Implenentatio:l)

- Should be accomplished by Nay 16

- APA Team approach will be used

5. Schedule:

- APA Staff work with AA staffs on rewrites May $14-16$

- Draft of Volume I and Volume II for Fri/Seamans May 28

- Draft Report to OMB on June 1 


\section{NOTES}

1. The Section "Other Federal Programs" has been inserted for only the Sub-unit. "Oil \& Gas Extraction" and is to be used as a guide for the Solar Thermal sub-unit of the Solar Electric unit.

It is not clear whether such other Federal inputs will be available for inserting in many of the Program Sub-units.

2. Federal Roles may not be appropriate for each sub-unit.

3. There is an overlap between the implementation and the Milestones/Output charts. We desire the Implementation. to improve the comprehensibility of the charts. 


\section{Technological}

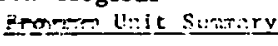

1)jecrives

The annual production from bicumens, tar sands ain oll sinale by 500 million barrels of oil, 5 作 baricls of shale oil.

Hid Tera (-26, 1, ): Tiansior technology to industivy for in-situ caivirsion of coal to intermediate or low BTU gas.

Long Twr: (2nint): Derslop i.n-situ teclinology for recovery of fuel 1.: lues from resources not ecuriomically recoverable by conventional means.

\section{Scrate:y}

o. Protuce mole ill and gas from extsting sources.

D Incriase rate of ricowery/comversion from existing sources. - Develop new suutces.

Subnralizun lnits (b; rank order)

o Oil at:l Gas l:-eraction

- In Stru Dil Sirale Processing

- Advanged Rescarch and supporting Technology

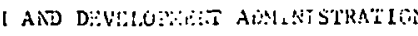
Prouralt Description

Solar Electric Applications Technology Uni

\section{Uil ind Cin: Fi:traction Subpropram}

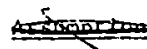

o Tan ind other legislative remedtes will be enact ad to parait field unjei:ntion.

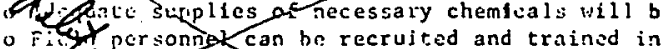

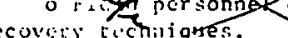
o Fil.tu bolicies ard heraorstrations will provide Investaer: incenstivi fire adoption cf advanced recovery techniques.

\section{Priblens:}

Techiplonsical

O Data liatrations prevent making iigh success projability furceants of increnental output.

- iossible breakouts of stimulation flulds from unicized

reservoirs may poss: catastrophic risk to entrenreneur. o Massive hydraulic or chetnical explosive fracturi.ts is
especially.eisky for trdividual wells.

\section{Insticterinin!}

- U:tavailability of resources because of it 3 stated proprictory nature.

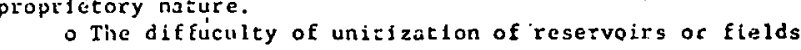
te. highly fragmented ownership.

ing ava ical data or technologles because of a stated propriarory nature. 


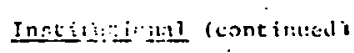

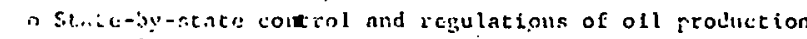
centusuration.

o Antl-trust nroblems because of mutual benefit agreements among nae ior ofl. producers.

incice contral:s and taxatlon make high risk investments iny inciurtry in enhancid recovery uncertain.

\section{Esderel rinte}

a Puble tistrust of ofl industry requires even handed Goverriment seratntent for teasing, developmental support, output price guarantecs.

C Cost stiaing proffers for stimulation projects should be bid bilsis.

- Equitabie tax and $p$ :ice treatment for recovery increments from stimulation compared vith new drilling.

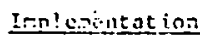

Initially, ERDA will share the costs of projects involving new reeinolngy for demonstratirg fluid injections and thernial methods to recover oft as well as Fydraulic and/or chemical explosive cracturing of gas-containirg formations. A few major demonstrations are a!ready undiertay; more aill be initiated in FY 76 . As expertence with these denonstraclons grows, new lnnovative demonstration projects will promptly be azt1vated. Substantiation by 1980 of the comecrcinl viability of som 3 or all of the tested methods is soughe. itilizacton of the ne:fer technology could yield an increase by early 1983 in dally production of 1 million barrels of oll and 6 blllion cuble feet of natura I gas.

\section{$-2-\frac{1}{30}$}

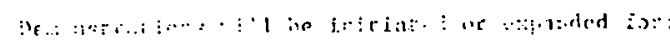

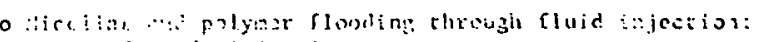
carbon din:ide injections malcons

in wiested condistons: O thermat recivery

. olfrac extraction and cyclic solvent stimulacion: o massive hylraulic fracturing;

a leviated wells and earth fracture systems.

\section{$\underline{1979-9 ?}$}

Deianstations vill be evaluated. P.esulting technology vill be transferred to industry.

\section{Othrr Federal Programs}

\section{Agency}

Dept. of Interior

N. Sclence Foundation

Texas Railrod Commission....

Dept. of Comnerce

\section{Outnuts}

Improved reservoir data for unitization Study relating water floodir.g yield's to down hole temperatures

$\mathrm{CO}_{2}$ proxinity to viscous oil reservolrs Study of distribution pipelines for muletple product distribution 


\section{In sirieg:i slinle Procusaim Subprogram}

\section{Assumentinrs}

$:$ Ressurce land: will be made available from both publicly and wivately held seurces.

- Venture capital can te attracted to demonstration projects. o Norld nil prices will remain above the break-even point. for shale o.11.

$$
\text { - Necessary water can be made avallable. }
$$

\section{Federal Rn!e}

o Lenger raige product price guarantees may be required to obtain process scalcups.

- Interacting conservation, wlldlands, wildlife, Indian lands, and othcr constituencles must be weighed against domestic encryj requirements.

\section{probic:s}

Institutional

- Price structu:e for syacrude is clouded and therefone private investment capital is limited.

- Land acquisition procecures are not clear.

o Acceptability of envirenmental and socio-economical impacts on the sparsely populated Western areas are unclear.

\section{Teclirolorical}

o Uleimate resource recovary efficiency has not been demontrated at an

- Demonstration of contro: ability and acceptability of subsidence, structural water lrapacts and product burn 18

O No transport racthods exist to move the product to market in the quantities produced.

\section{Impinan}

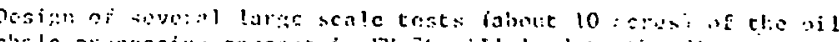

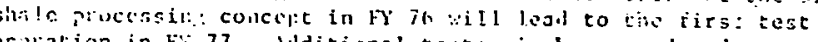

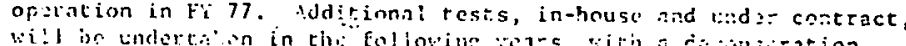

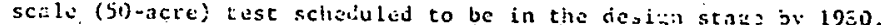
Finawihile, basinning with the design phase in Fi: 76 , an abjoge. ground sirnulation Eacility for demonstration of in situ oil sha? gasification vill started, Actual field tests of the ficiity are p:ojected for $F Y$ 80. If successful, the proces: will make possible co:tncrcial installations producing 250 billion 370 equivalent by 1985 .

\section{$1970-77$}

f Ficld test nuinher 1 ahove-grount, engineering scale, modified vertienl retorts will begin. Ficld test number 1 and number 2 and cvaluation sf rodifies horizontal retorting will take place.

o A 25 ton/day test facllity for gas production wlll stare

Operation of field test number 1 of true in situ oil shale processing will be initiated.

\section{$1979-82$}

- Evaluations of test undertaker. in FY 76 and it will continue. o Field test number 5 of truc in situ oil shale prjcessing will begin in FY 78 and continue through FY 82.

0 Ficld tests 5 and 6 of modified hor 1 zontal retorting and their evsluations will a) so begin and run for the entre period. o The 25 ton/day te:t facility for gas production w1ll continue operation through 1981.

$\underline{1983}$

- The 25 ton/day cest facility for gas prodyction from of shale will be followed by a full field test, s. ? tensive operation and evaluation in 1983. 


\section{In Sir.t cont cosificntion Suhriogran}

Assulin:Einias

a Envlronsental imaset probleins en be idc:ae ified and solved.

Optirium borchiole confiaurations can be determined.

0 F.ffective bed pre-ignition preparation means can be

deternined.

- Econounical systems of underground gasification and aboveground bollers/turbines can be designed and demonstrated.

\section{Federal Role}

- International cooperation will.continie on in situ coal gasticition.

Identification and solution of problems involving privately owned data and technoiogies.

resers we 11 attuned to in situ gasification necds so bert mathods of resource recovery may result.

Probleass

Institutional

- Longer cerm, Stabilizea prices for product gas.

- Inequity of depletion treatments between coal and gas.

- Availability of coal lands for in situ gasification.

\section{Technical}

- Control end decerminaticn of sibsidence.

- Control and capture of products.

- Directional control of IIre front.

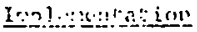

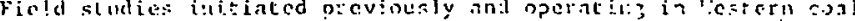

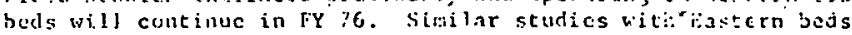
wi.1! be started uip. Varigus methods to increase sas leat whe (e.3., oxyscul :ijection) will he tested, as will t!re feesil.ibity of direct mentisituol andor amonia productioa. Fifiorts in subsequent years will be centered on scallno up to a $30 \mathrm{C}$ it: demonstration system of coal underground gasification that include
environmental controls, such as removal, of. Sox from the produced ga :

\section{$\underline{1976-77}$}

O Finstern Area field pilot test will be run and eveluetcd. - Evaluation of oxygen injection experiments, Hestern Area field pilat test will be cumpleted.

o Decision to proced with prototype derronstration unit construction will be made; construction will begin if decision is affirmative.

\section{$\underline{1979-80}$}

- Gasification cxperiment at the prototype demonstration unit will be completed and evaluated by 1980 .

- Decision to proceed, followed by design and construction, of a commercial scale demonstration plar: is scheduled for $19 ; 9$. Results of extensive operation and evaluation will be in by 1939.

Adyanced Research and Supgorting Technology Subnrogram

Assumpticas

- The utilization of fossil fuels from tar sands and oil shale deposits requires detailed product characterization and refining process developments wh proceed lncluding possible autonoslve 


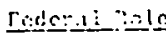

o lise of Energy Centers, National Livoratorics, acadenis and teclinically centered orgari zations to collect characterizing dats techice instrumentarion ard controlabilicy and guarantec public acceptability of activitics.

Problems

\section{Teclinicis}

- Produic liquids poorly cliaracterized relative to further refinability or end uses.

Prumpt, better deftiteion of equipment materlals problems to minimize technology impdiments.

\section{Ians erecintation}

Concurreit with the worl: oo other subprogram units, and in support or theis, there will be carried ont:

o Physical and clienlcal characteriration studies of tar sand and shale oil

O rofining tests of crude tar sands and shalo oils to dofine cunditions naded for the connercial processing of these fuels to distillates;

o auionotive tasts to determine the suitability of these distillate ficls for conventional mot sr transportation;

o basic and apilied cclloid chemistry studics for improved additives and polymers for waterflooding and micellar/polymer tlood-

Ing; o system studies to compare progress ard cost of the program wh estinated cost of product, market requirements and environmenta 1 conditions. 


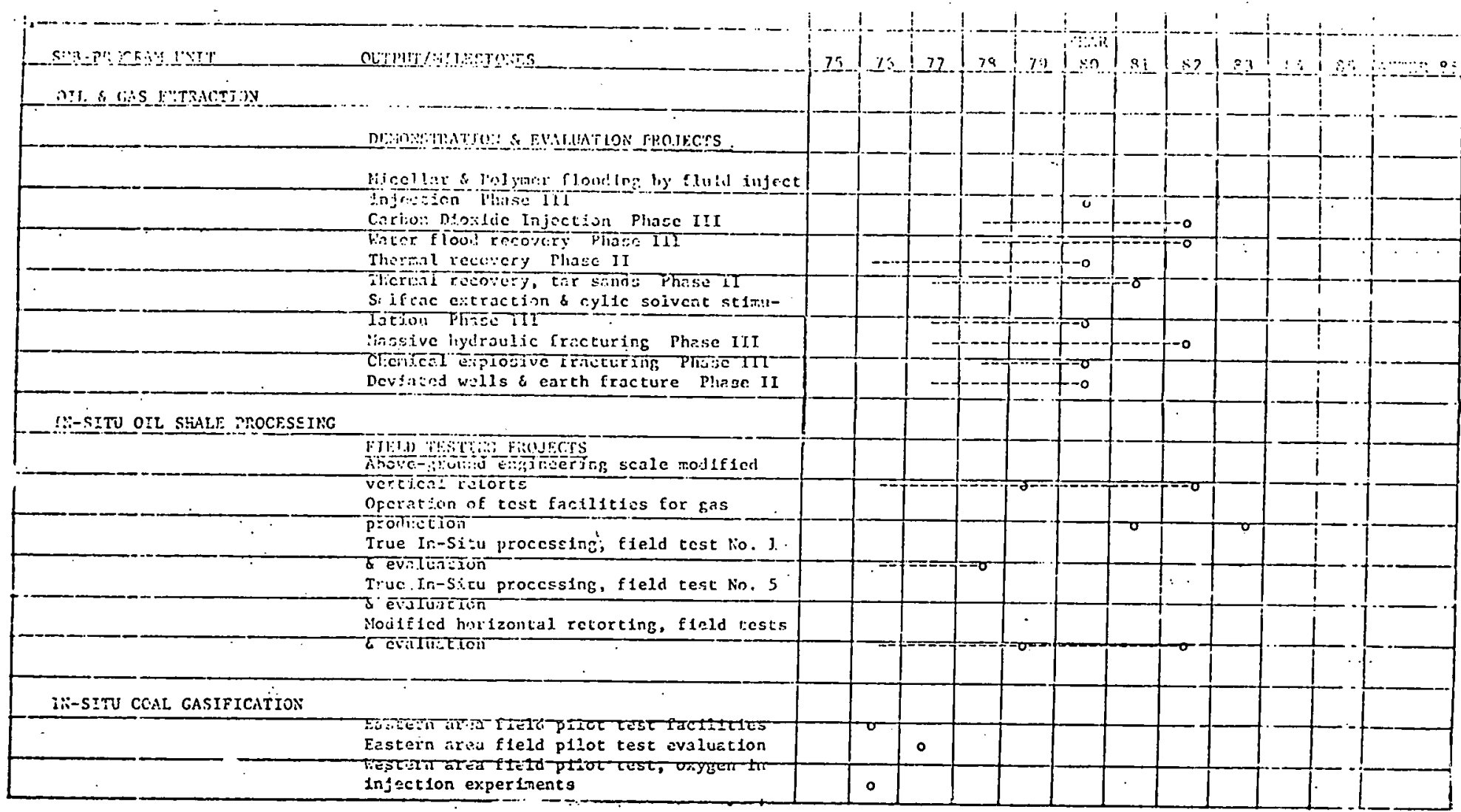




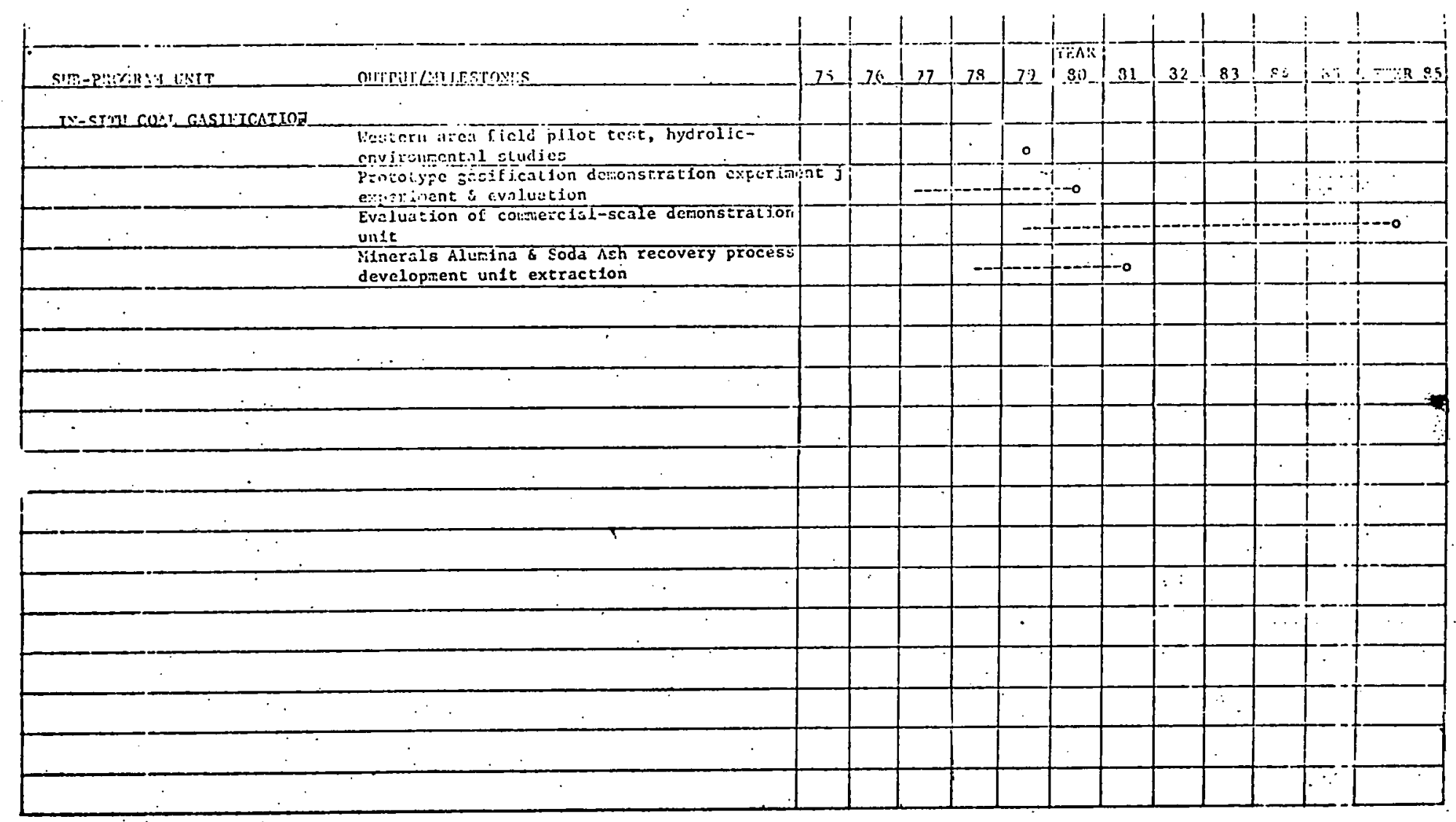


APPENDIX B

SOLAR ELECTRIC APPLICATIONS

"PHASE III" BUDGET SUBMISSIONS 


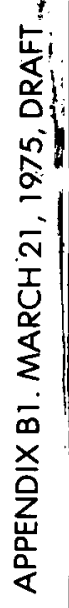


APPENDIX B B 1

MARCH 21, 1975, DRAFT

B 1-1 
The objective of the Solar Electric Applications (SEA) Program is to establish the technical and economic feasibility of using solar thermal, photovoltaic energy, wind energy and ocean thermal energy conversion to produce electricity. This will be accomplished through research, development and demonstration (RD\&D) programs. These programs will result in the operation and test of demonstration plants in the near-term and the expanded use of commercial plants in the mid and long-terms.

Government sponsorship of the solar electric programs is required in the formative years to ensure that first-generation commercial plants can begin operating as early as possible. This sponsorship will also create the integrated government-institutional-industrial basis so necessary for the timely accomplishment of the overall program objectives. The specific objectives, strategy and approaches of the program subunits comprising the Solar Electric Applications are as follows:

\section{A. Solar Thermal}

The major objectives of solar thermal are: (1) to provide full system capability for production of supplementary. electric power and thermal power in the 1.980's to conserve natural resources and (2) to provide a full system capability for total energy sys tems (combined electric-thermal) for urban and rural communities, industrial/institutional load centers and military bases at rates competitive with conventional energy sources.

Few fundamental technical limitations exist to prevent substantial application of solar thermal systems. The subprogram objective is therefore to develop and demonstrate the economically competitive capabilities of intermediate load (load-following) solar thermal power plants and solar total energy systems.

Parallel contracts were awarded in 1975 for subsystem hardware for a load following/intermediate load central receiver solar thermal electric power plant. These contracts include the development and test of collector, receiver, and thermal storage concepts. A $5 \mathrm{MWth}$ Solar Thermal Test Facility will be constructed in 1976 to test the subsystem hardware. Construction of a 10MWe Central Receiver Pilot Plant will be initiated in 1977 and the plant integrated with a utility grid in 1979 in cooperation with several utilities. This pilot plant will be followed by a second generation pilot plant. A rooMwe demonstration Central Receiver Plant will be operational by 1985 to demonstrate technical and economic viability. Similar developments are planned for Total Energy Sys tems (combined electrical-thermal), Distributed Collector Systems and Hybrid Solar Thermal Systems. Additional Research and Development studies covering collector/surface coatings, high 
temperature material development and solar thermal mission/system analysis are also planned.

\section{B. Solar Photovoltaic Conversion}

A major near-term objective of the Solar Photovoltaic Conversion is to stimulate a U.S: production capacity of 500 MiWe per year of silicon solar arrays at a price of less than $\$ 500$ per peak kilowatt by 1984 . This will be accomplished by initiating an annual procurement schedule for these arrays, ranging from $75 \mathrm{KW}$ in FY 76 to $4 \mathrm{MW}$ in FY 83 . These arrays will be used in a blend of applications to generate electrical energy. The initial $75 \mathrm{KWe}$ (peak) of arrays will be used in cooperation with DOD on isolated military bases for demonstrations of energy self-sufficiency beginning in FY 76. If these demonstrations prove successfuT, DOD is planning to buy substantial quantities of solar arrays for further applications starting at an annual level of $100 \mathrm{KWe}$ (peak) when array prices approach $\$ 5,000$ per peak kilowatt, and at an annual level of 5 MWe (peak) for an array price near $\$ 2,500$ per peak kilowatt. Studies on promising concentration systems, operating and maintenance procedures, electrical storage and power conditioning, electric utility grid interfaces, and materials and device testing and standardization procedures, as well as studies of environmental, legal, societal, institutional and other possible system constraints, will also be conducted.

A research and development program on alternative materials and lowcost devices"will be pursued in parallel with these efforts to insure meeting about $1 \%$ of the Nation's electrical power requirements goals in the 1990 to 2000 year period.

\section{Wind Energy Conversion}

The objective of the Wind Energy Conversion is to accelerate the development and commercial use of economic reliable wind energy systems. Such systems have a minimal environmental impact, use a non-depletable energy source and are capable of producing significant energy outputs.

The strategy of the wind energy conversion programs will be to develop a series of experimental systems of increasing size and capability, supported by a research and technology base, leading to incrementally installed multiunit demonstration systems, jointly funded with users, in the early 1980s. While the emphasis is on electrical generation for electrical utility use; direct heat, crop drying and fertilizer, manufacturing, and fuel generation will also be demonstrated. Since large-scale production of individual units that are small by utility standards (one MW per unit) is anticipated, the Federal involvement in the development of suitable production facilities by the mid-1980s is a possible portion of the strategy.

The planned R\&D program would lead to verification of successful systems by 1979, several 100 MW demonstrations by the early 1980s and 
mass-production capabilities in excess of 15,000 MWe per year, at a cost of $\$ 250$ - $\$ 300$ per rated kilowatt in the mid term.

\section{Ocean Thermal Energy Conversion}

The objective of Ocean Thermal Energy Conversion (OTEC) is to demonstrate the feasibility of producing electricity through the ocean temperature differences. The feasibility of producing energyintensive fertilizers and fuels from seawater and refining metals will also be investigated.

The commercial acceptance of the sea-based ocean thermal conversion stations requires the full-scale demonstration of system performance and cost estimates. Studies now in process indicate the technical knowledge is available for building an experimental prototype. The additional engineering development required is of the adaptive and scale-up variety. The scientific efforts paralleling this effort will provide design optimization and reduce construction costs. The program development emphasis has been placed on advancing a baseline design incorporating low-risk design concepts and incorporating design improvement only as their feasibility is documented. This approach ensures that the overall progress of the program will not be impeded.

The initial prototype is planned around the use of a full scale platform as hydrodynamic, thermodynamic mooring and environmental effects do not lend themselves to subscale testing. Systeil design, critical component testing, material, and implementation studies are in process. Land test facilities will be constructed in 1976 and sea test facilities in 1977. The prototype floating ocean thermal plant will be tested in 1981. The first commercial ocean thermal plants will be brought on line by 1985 . Production of these and larger size plants can then be accelerated in the intermediate-term. 
U. S. ENERGY RESEARCH AND DEVELOPMENT ADMINISTRATION

PROGRAM OUTPUTS

Total Est.

Cost Through

Completion

\begin{tabular}{ll|l|lll|l}
$\begin{array}{c}\text { (Millions of } \\
\text { Dolliars) }\end{array}$ & Near Term & & \multicolumn{3}{c|}{ Mid Term } & Long Term \\
\hline
\end{tabular}

V. Solar Electric Applications

A. Solar Thermal

1251.7

- 40,000 MWe generated saving 320.million barreis of oil per year

1. Central Receiver Power Plant Decision to build 10 Mlie Pilot Plant Decision to build 100 Mile Demonstration Plant

๘
心

Decision to build First Commercial Plant (100 to 300 Mive)

10 MWe Pilot Plant checked out and operating

100 MWe Demonstration plant in operation

Initial Commercial 100 to 300 MWe

Plants in operation

$X($ in work $)$

$$
x(1979)
$$

$\bullet(1979)$

$\bullet(1985)$

$\cdot(1987)$ 
U. S. ENERGY RESEARCH AND DEVELOPMENT ADMINISTRATION

PROGRAM OUTPUTS

A. Solar Thermal

(Continued)

2. Solar Thermal Test Facilities

Decision to build Central Receiver Facility

Decision to build Distributed

Collector Facility

Central Receiver Facility Operating

Distributed Collector Facility

Operating

$\stackrel{00}{2}$

3. Solar Total Energy Systems

Decision to build Pilot 200KWe, 2 MWth (System \#1).

Decision to build Pilot 200KWe, 2MWth (Sys tem \#2)

Decision to build 10MW'th (System \#1) Demonstration Plant

Decision to build 10MWe, 200MWth

(System \#2) Demonstration Plant
Total Est.

Cost Through

Completion

(Millions of

Dollars)

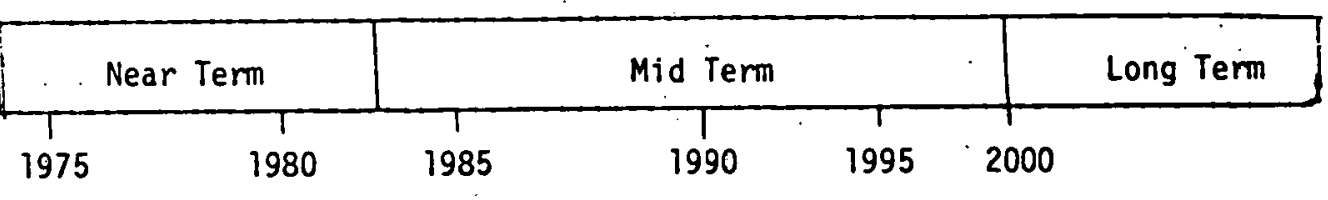

(89.1)

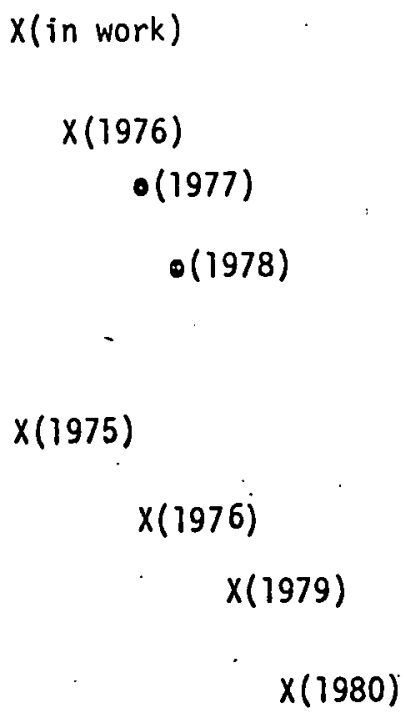

$x$ (in work)

$x(1976)$

$\bullet(1977)$

-(1978)

$x(1975)$

$x(1976)$

$x(1979)$

$x(1980)$

$(265,8)$ 
U. S. ENERGY RESEARCH AND DEVELOPMENT ADMINISTRATION

PROGRAM OUTPUTS

Total Est.

\begin{tabular}{l|ll|lc|c|c|}
$\begin{array}{l}\text { Cost Through } \\
\text { Completion } \\
\text { (Millions of } \\
\text { Dollars) }\end{array}$ & Near Term & \multicolumn{3}{c|}{ Mid Term } & $\begin{array}{l}\text { Long } \\
\text { Term }\end{array}$ \\
\hline
\end{tabular}

\section{A. Solar Thermal}

(Continued)

3. Solar Total Energy Systems

(Continued)

200 KWe, 2MWth Pilot Plants

(Systems 1 \& 2) checked out

and operating

$\bullet(1981)$

10MWe, 200MWth Demonstration Plant

(System \#1) in operation

$\bullet(1985)$

10 MWe, 50MWth Demonstration Plant

(System \#2) in operation

$\bullet(1986)$

4. Distributed Collector Power Plant

Decision to build 10 MWe Pilot Plant

(114.1)

Decision to build 100MWe Demonstration Plant

10MWe Pilot Plant checked ost

and operating

$x(1982)$

100MWe Demonstration Plant in

operation

$x(1977)$

-(1981)

-(1987) 
U. S. ENERGY RESEARCH AND DEVELOPMENT ADMINISTRATION PROGRAM OUTPUTS

Total Est.

Cost Through

Completion

(Millions of

Dollars)

\begin{tabular}{|ll|lll|l|}
\hline & Near Term & & Mid Term & & $\begin{array}{c}\text { Long } \\
\text { Term }\end{array}$ \\
\hline 1975 & 1980 & 1985 & 1990 & 1995 & 2000 \\
\hline
\end{tabular}

A. Solar Thermal

(Continued)

5. Hybrid Solar Thermal Systems

$(161.3)$ Decision to build initial pilot plant

$\times(-1978)$

Pilot Plant \#1. checked out and operating

Pjlot Plant \#3 checked out and operating

6. Research and Development

(114.4)

70 7 Program Support

(19.3)

(1981)

(1983)

$\infty$ 
U. S. ENERGY RESEARCH AND CEEVELOPMENT ACMINISTRATION PROGRAM OUTPUTS

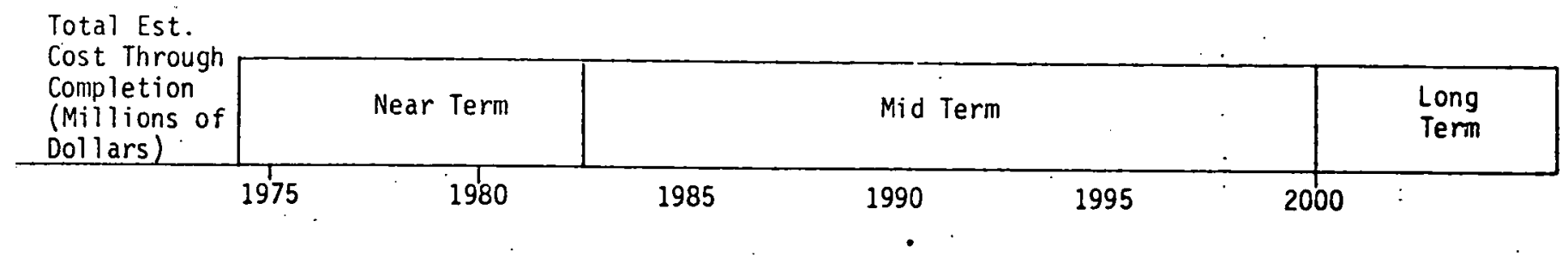

v. Solar Electric Applications

(Continued)

B. Solar Photovoltaic Conversion

1. Systems and Applications

$1,427.9$

$(225.6)$

Candidate SPC Applications selected

SPC System Constraints Defined

SPC Demonstration Plan selected

SPC Systems and Sub-Systems Specified

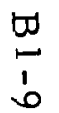

Operation of Demonstrations

Initiated: $75 \mathrm{KW} / 1976$;

$300 \mathrm{KW} / 1977 ; 500 \mathrm{KW} / 1978$

$1-$ - HW/ $1979 ; 2-M W / 7980 ; 4-N W /$

1981; 7-MW/ 1982;11-PIW/ 9983

2. Low-Cost Silicon Array Project

Silicon Material Process SElected

Silicon-Array Accelerated-Lifetime Test-Approach Selected

Silicon-Sheet Growth-Process Selected

Automated Array-Fabrication Process Selected

Go-Ahead on Construction of 500-MW Fabrication Plant

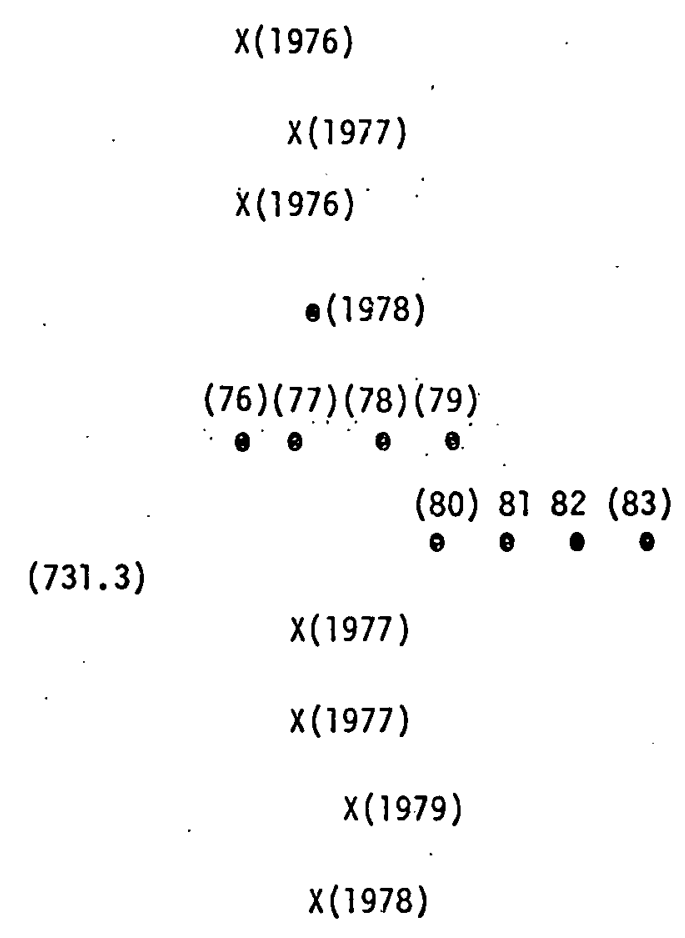

$x(1979)$ 
U. S. ENERGY RESEARCH AND DEVELOPMENT ADMINISTRATION

PROGRAM OUTPUTS

Total Est.
$\begin{aligned} & \text { Cost Through } \\ & \text { Completion } \\ & \text { (Millions of } \\ & \text { Dollars) }\end{aligned}$

v. Solar Electric Applications

B.2 Low-Cost Silicon Array Project (Continued)

Go-Ahead on Continued-Production for Demonstrations

Pilot-Plant for Silicon-Material in Operation

Pilot-Plant for Large-Area SiliconSheets in Operation

Pilot-Plant for Automated-Production of Arrays in Operation

to Large-Scale Plant for Silicon-Material

- in Operation

Large-Scale Plant for Automated-
Production of SPC Arrays: $\$ 500 / \mathrm{KL}$

Delivery of SPC-Arrays for ERDA Demonstrations 75KW/1976; 150KW/1977; 2.00KW/ 1978;50 OKW/1979; 1-MW/1980; 2-MW'1981; $3-M W / 1982 ; 4 M W / 1983$

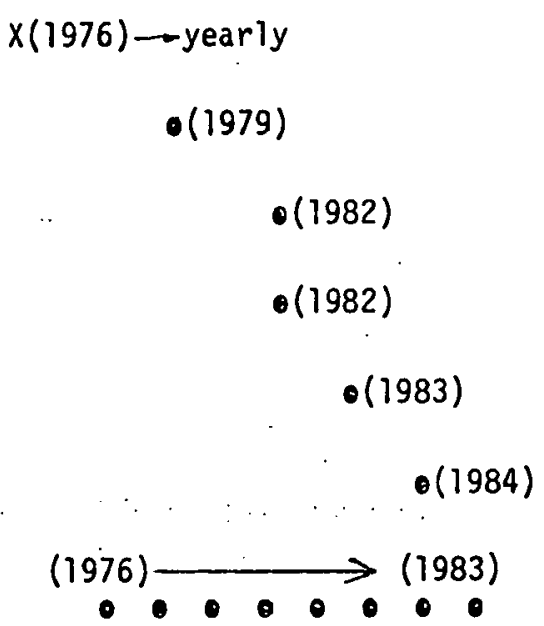


U. S. ENERGY RESEARCH AND DËVELOPMENT ADMINISTRATION

PROGRAM OUTPUTS

Total Est.

Cost Through

Completion

(Millions of

Dollars)

\begin{tabular}{ll|lll|l|}
\hline & Near Term & & Mid Term & & $\begin{array}{l}\text { Long } \\
\text { Term }\end{array}$ \\
\hline 1975 & 1980 & 1985 & 1990 & 1995 & 2000
\end{tabular}

V. Solar Electric Applications

B. Solar Photovoltaic Conversion (Continued)

3. Concentrator Systems

(84.9)

Concentrator System Design Selected: $\$ 5,000 / K W$ in 1976; $\$ 250 / K W$ in 1981

Production and Operation of ioncentrator Systems: $\$ 5,000 / \mathrm{KW}$ in 1977; $\$ 250 / \mathrm{KW}$ in 1984

4. Testing and Standards

Solar Array Performance Measurements Approach Selected

Go-Ahead on SPC Test and Standardization Facility

Final Performance Specifications defined

Test and Standardization Facility in Operation

5. Research and Development

Other SPC Candidate Materials and Devices Selected for Further Development

Go-Ahead on Large-Scale Production

$x(1976) \longrightarrow$ yearly $x(1.984)$ 
U. S. ENERGY RESEARCH AND DEVELOPMENT ADMINISTRATION PROGRAM OUTPUTS

Total Est.
$\begin{aligned} & \text { Cost Through } \\ & \text { Completion } \\ & \text { (Millions of } \\ & \text { Dollars) }\end{aligned}$

V. Solar Electric Applications

B. 5. Research and Development

(Continued)

Thin-Film SPC Demonstrated at 10\% Efficienty

Feasibility of $\$ 100 / \mathrm{KW}$. Arrays

Demonstrated

$\bullet(1980)$

$50,000 \mathrm{MW} /$ Year Produced at $\$ 100 / \mathrm{KW}$

-(1984)

6. Energy Storage and Power Conditioning (168.0)

Final Candidates Selected

Test Program Approach Selected

Evaluation of Energy-Storage and Power-Conditioning Completec

Prototype Testing Completed

Testing of Control Systems Completed

7. Assessment of Goals

Plant Ownership and Operation ?lan Selected

(5.7)

$\cdot(1983)$

$$
\begin{gathered}
x(1979) \\
\times(1977) \\
0(1977) \\
0(1978)
\end{gathered}
$$

(1979)
-(1992)

$x$ Decisions - Results 
U. S. ENERGY RESEARCH AND DEVELOPMENT ADMINISTRATION

PROGRAM OUTFUTS

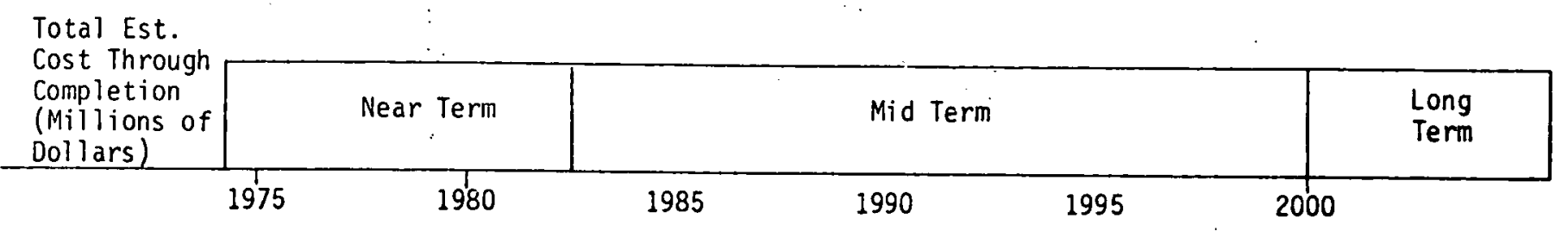

\section{Solar Electric Applications}

C. Wind Energy Conversion

109.0 (R\&D)

331.2 (RD\&D)*

1. Research, Technology and Program Development

Initial Application Regions Selected

Recommendations on Possible Incentives

Initial WECS Systems Analyses Completed

Initial Env/Legal/Public

Acceptance Results

$(36.6)$

Site Selection Completed

2. Individual Farm WEC System

Decision to Implement Major Farm Demonstrațion or Incentives Program

Initial Heating and Cooling

Practicality of Fertilizer and Crop Drying Determined

$\bullet$ (1979)

(6.9)

$$
x(1978)
$$

-(1977)

-(1979)

3. 100-KW Systems

Sites Selected for Mod-1

Alternate Concepts Selected

Decision for Large Demonstration 
U. S. ENERGY RESEARCH AND DEVELLOPMENT ADMINISTRATION PROGRAM OUTPUTS

Total Est.

\begin{tabular}{l|l|ll|l|l|}
$\begin{array}{l}\text { Cost Through } \\
\text { Completion } \\
\text { (Millions of } \\
\text { Dollars) }\end{array}$ & Near Term & & Mid Term & & $\begin{array}{c}\text { Long } \\
\text { Term }\end{array}$ \\
\hline
\end{tabular}

\section{Solar Electric Applications}

C. Wind Energy Conversion (Cont'd:

Fabrication of Mod-0, Completed

Initial Tests Completed, Mod-0

Initial Test Completed on Mod-1

Practicality of Mod-2, Alternate Concepts Determined

4. Mit-Scale H:ECS

Sites Selected for Mod-1, MiW-Scale

Sites Selected for Mod-2,

Mb-Scale

Alternate Concepts for MW-Scale Selected

Fabrication of Mod-1, MW-Scale Completed

Fabrication of Mod-2, MW-Scale Completed

Tests of Mod-1 and 2, MW-Scale Completed

Practicality of MW-Scale Alternate Concepts Determined

$(\$ 31.8 M)$

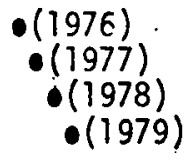

$$
\begin{aligned}
& x(1976) \\
& x(1977) \\
& x(1977) \\
& \cdot(1977) \\
& \bullet(1979) \\
& \bullet(1980) \\
& \bullet(1981)
\end{aligned}
$$


U. S. EMERGY RESEARCH AND DEVELOPMENT ADMINISTRATION PROGRAM OUTPUTS

Total Est

\begin{tabular}{lll|lll|l|l|}
$\begin{array}{l}\text { Cost Through } \\
\text { Completion } \\
\text { (Millions of } \\
\text { Dollars) }\end{array}$ & Near Term & & Mid Term & & $\begin{array}{l}\text { Long } \\
\text { Term }\end{array}$ \\
\hline
\end{tabular}

v. Solar Electric Applications

C. Wind Energy Conversion (Cont'd)

5. Large-Scale, Multi-Unit

Initial 10-PIN Multi-Unit WECS

Committed to Incremental

Construction

Initial 100-MW Multi-Unit WECS

Committed to Incremental

Construction

Commitment to Large-Scale Production of MW-Scale WECS

Fabrication of 10-MW Multi-Unit WECS Demonstration Completed

Fabrication of 100-MW Multi-Unit

WECS Demonstration Completed
-7 Initial Tests of 10-MW Multi-

(240.7)

$x(1978)$

- Unit WECS Demonstration

Completed

Initial Tests of Fourth 100-MW

Multi-Unit WECS Demonstration Completed

(170 $\mathrm{MW}_{\mathrm{e}}$ Capacity Achieved)

Large-Scale Production of WECS Started*

$\left(15,000 \mathrm{MW}_{\mathrm{e}}\right.$ Capacity Achieved)*

$\times(1979)$

$x(1981)$

$\bullet(1979)$

$\cdot(1981)$

$\cdot(198 i)$

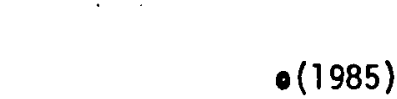

-(1981)

-(1983)

$\bullet(1985)$

*Assumes major Federal commitment and incentives program.

Costs of WECS production and Federal incentives program are not included in funding shown. 
U. S. ENERGY RESEARCH AND DEVELOPMENT ADMINISTRATION PROGRAM OUTPUTS

Total Est.

Cost Through

Completion

(Millions of

Dollars)

\begin{tabular}{|ll|lll|l|}
\hline & Near. Term & & Mid Term & $\begin{array}{c}\text { Long } \\
\text { Term }\end{array}$ \\
\hline 1975 & 1980 & 1985 & 1990 & 1995 & 2000
\end{tabular}

V. Solar Electric Applications (Continued)

D. Ocean Thermal Energy Conversion

1. System Studies.

$704.9^{1}$

(2.5) $\quad x$ (in work)

Award contracts to study technical and economic feasibility of acean thermal differences, conduct engineering evaluations and develop test program

2. Land-Based Test Facility Award design contracts Award construction contracts

$\varpi \quad$ Facility design completed First phase of construction complete Second phase of construction complete

3. Sea-Based Test Facility Award design contracts Award construction contracts Facility design complete Facility operating

$$
\begin{aligned}
& x(1975) \\
& x(1976) \\
& \cdot(1976) \\
& \cdot(1977) \\
& .(1978)
\end{aligned}
$$

\footnotetext{
Tं Estimates through 1985
}

\author{
X Decisions - Results
}


U. S. ENERGY RESEARCH AND DEVELOPMENT ADMINISTRATION

PROGRAM OUTPUTS

Total Est.

\begin{tabular}{|c|c|c|c|c|c|}
\hline $\begin{array}{l}\text { Completion } \\
\text { (Millions of } \\
\text { Dollars) }\end{array}$ & Near Term & & Mid Term & & $\begin{array}{l}\text { Long } \\
\text { Term }\end{array}$ \\
\hline & 1980 & 1985 & 1990 & 1995 & \\
\hline
\end{tabular}

v. Solar Electric Applications

D. Ocean Thermal Energy Conversion (Continued)

4. Critical System Components Research and Development

Award heat exchanger research and development contracts

Award mod 0 design and construction contract

Award research and development contracts on turbines, pumps, anchoring/mooring/dynamic positioning deep water pipe, materials/corrosion biofouling and screening

Award mod 1 design and construction contract

Award systems engineering study of anchoring/mooring/dynamic positioning

Award contracts for prototype and long-lead time pumps, turbines and platform equipment

Construction of Mod 0 designs initiated Construction of Mod 0 designs complete and tests underway

\section{$x$ (in work)}

$x(1975)$

$x(1975)$

$X(1977)$

$x(1977)$

$X(1978)$

$\bullet(1976)$

$\bullet$ (1978) 
U. S. ENERGY RESEARCH AND DEVELOPMENT ADMINISTRATION PROGRAM OUTPUTS

Total Est.

Cost Through

Completion

(Millions of

Dollars)

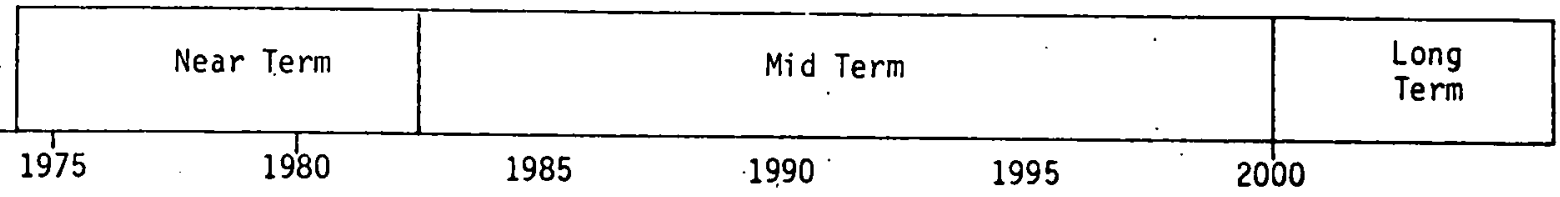

V. Solar Electric Applications

D. 4. Ocean Thermal Energy Conversion (Continued)

Construction of mod 1 designs initiated

Complete systems engineering study of anchoring/mooring/dynamic positioning

Construction complete and tests underway

$\bullet$ (1978)

$\bullet(1978)$

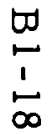


U. S. ENIERGY RESEARCH AND DEVELLPMENT ADMINISTRATION

PROGRAM OUTPUTS

Total Est.

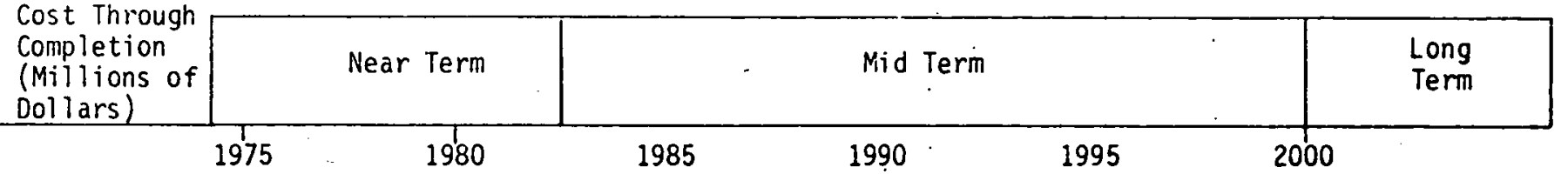

v. Solar Electric Applications (Continued)

5. Prototype Floating Power Plant

Award Preliminary Design

Contracts (2) for 100 Mile

Floating Plant and 25 Mwe Power

Module (hull to be full size,

surface and semi submersible

options to be investigated

Select Contractor for Final

Design and Award Contract

Award Contract for Purchase of Long-Lead Time Materials and Equipment for Prototype 100 . Whe Floating Plant

Award Contract For Construction of Hull and Initial Power Module

\author{
$x(1979)$
}

Prel iminary Design of Prototype.

100 Mive and 25 MWe Power Module Complete

Detailed Design of Prototype 100 MWe and 25 MWe Power Module Complete

$x(1981)$

$\bullet(1981)$ 
U. S. ENERGY RESEARCH AND DEVELOPMENT ADMINISTRATION PROGRAM OUTPUTS

Total Est.

\begin{tabular}{lll|lll|l|}
$\begin{array}{l}\text { Cost Through } \\
\text { Completion } \\
\text { (Millions of } \\
\text { Dollars) }\end{array}$ & Near Term & & Mid Term & & $\begin{array}{l}\text { Long } \\
\text { Term }\end{array}$ \\
\hline
\end{tabular}

V. Solar Electric Applications (Continued)

5. Prototype Floating Power Plant (Continued)

Test and Evaluation of Prototype 100 lite Plant and 25 MWe Power Module Commences

.$\quad \bullet(1983)$

6. Commercial Demonstration Power Station (250.0)

Award Contract For Power Modules for Commercial Demonstration Model (Protytype Huil Will Be Retrofitted with new Modules)

Test of 100 Mile Commercial Demonstration Model Containing Four Improved 25 Mive Power Modules

7. Advanced Research and Technology

Award Study Contracts on Energy Delivery, Product Mix Impact and Siting, Thermal Resources and Lega) Considerations (Includes provision for Maritime Administration assistance in establishing platform design requirements) 
U. S. ENERGY RESEARCH AND DEVELOPMENT ADMINISTRATION PROGRAN OUTPUTS

Total Est.

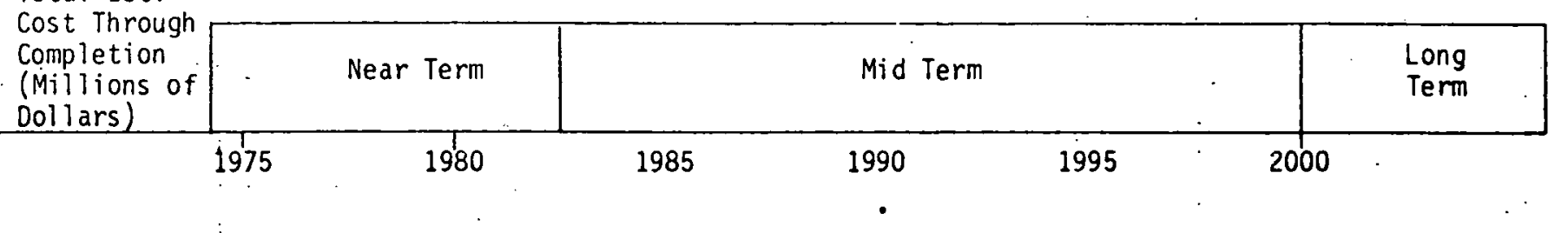

1. Solar Electric Applications

(Continued)

8. Other Renewable Energy Resource

Studies

Award Contract to Review Potent:al

of Ocean Currents, Waves, Tides

and Salinity Gradients as Energy

Source 
U. S. ENERGY RESEARCH AND DEVELOPMENT ADMINISTRATION

PROGRAM PROJECTION SUIAMARY

(Dollars in Millions)

SOLAR ELECTRIC APPLICATIONS (SEA) PROGRAM

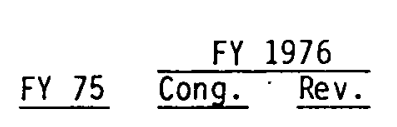

Operating Expenses

Capital Equipment.

Plant.

Total SEA Program...............

\section{0}

0.5

-

27.05
Transition
Period

$\frac{\text { Period }}{\text { Cong. Rev. }}$

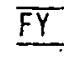

Program Projections

\begin{tabular}{|c|c|c|c|c|c|}
\hline 37.9 & 169.5 & 215.4 & 214.4 & 221.2 & 208.7 \\
\hline 7.0 & 43.7 & 52.5 & 77.4 & 107.2 & 132.4 \\
\hline 2.0 & 36.3 & 46.2 & 87.2 & 1.19 .1 & 208.5 \\
\hline .9 & & 314.1 & 379.0 & 447.5 & 549.6 \\
\hline
\end{tabular}

Thru Completion

Where Applicable

516.1

243.5

742.5

1502.1

FUNDS FRON OTHERS (not added to EROA total)

A. Solar Thermal

(Anticipated Utility participation)

8. Solar Photovoltaic Conversion

(Department of Defense)

2.0

3.5

6.4

15.

33.0

50.0 (Thru -1984)

C. Wind Energy Conversion (Joint Funding from Utilities)

$6.0 \quad 36.0 \quad 73.5$ (Thru 1986) 
U. S. ENERGY RESEARCH AND DEVELOPMENT ADMINISTRATION

PROGRAIA PROJECTIONS

(Dollars in Millions)

SOLAR ELECTRIC APPLICATIONS (SEA) PROGRAM

\section{OPERATING EXPENSES}

A. Solar Thermal

1. Central Receiver Power Plant

2. Solar Thermal Test Facilities

3. Solar Total Energy Systems

4. Distributed Collector Power Plant

5. Hybrid Solar Thermal Systems

6. Research and Deveiopment

7. Program Support

Total

$\stackrel{\varpi}{\sim}$

B. Solar Photovoltaic Conversion
Transition

EY $75^{\circ} \frac{\text { FY } 1976}{\text { Cong. ReV. }}$

Period

Program Projections

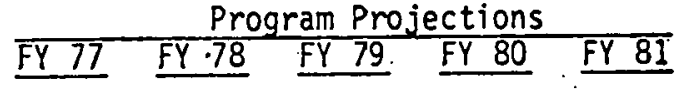

Completion

\begin{tabular}{|c|c|c|c|c|c|c|c|c|c|c|}
\hline \multirow[t]{2}{*}{5.1.} & & $8: 6$ & & 2.1 & 7.1 & 9.1 & 10.7 & 17.3 & 18.2 & 29.1 \\
\hline & & 5.3 & & 0.8 & 8.9 & 4.8 & 4.5 & 5.9 & 5.9 & 18.5 \\
\hline 2.3 & & 5.9 & & 1.3 & 12.0 & 15.4 & 18.2 & 20.1 & 19.4 & 13.0 \\
\hline \multirow{2}{*}{0.1} & & & & & 5.5 & 5.8 & 9.6 & 8.0 & 9.0 & 14.0 \\
\hline & & & 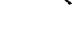 & & 1.9 & 4.1 & 6.3 & 9.2 & 10.8 & 28.0 \\
\hline 1.9 &.. & 6.0 & & 1.5 & 10.0 & 15.0 & 15.0 & 15.0 & 10.0 & 40.0 \\
\hline$\underline{0.6}$ & 1.95 & 1.2 & $\underline{0.5}$ & 0.4 & 1.9 & 1.9 & 1.9 & 1.9 & 1.9 & 7.6 \\
\hline 0.0 & & 27.0 & & 6.1 & 47.3 & 56.1 & 66.2 & 77.4 & 75.2 & 150.2 \\
\hline
\end{tabular}

$\begin{array}{llllllllllll}7.5 & 10.8 & 49.8 & 25.8 & 40.6 & 94.3 & 133.0 & 116.5 & 114.5 & 109.0 & 307.5 & \text { (Thru } \\ \text { 1984) }\end{array}$ 


\section{OPERATING EXPENSES}

(Continued)

C. Wind Energy Conversion

D. Ocean Thermal Energy Conversion

1. System Studies

2. Land Based Test Facilizy

3. Sea Based Test Facility

4. Critical System Components Research \& Development

5. Prototype Floating Plant Design

7. Advanced Research \& Technology
8. Other Renewable Energy Sources Studies

Total
U. S. ENERGY RESEARCH AND DEVELOPMENT ADMINISTRATION

PROGRAM PROJECTIONS

(Dollars in Millions)

SOLAR ELECTRIC APPLICATIONS (SEA) PROGRAM

\begin{tabular}{|c|c|c|c|c|c|c|}
\hline EST. & FY 1976 & $\begin{array}{l}\text { Transition } \\
\text { Period } \\
\end{array}$ & & Program Projections & & Thru \\
\hline 75 & Cong. Rev. & Cong. Rev. & FY 77. & FY 78 FY 79 FY 80 & FY 81 & Completion \\
\hline
\end{tabular}
6.5
12.7
$4.2 \quad 16.8$
$\begin{array}{lll}15.8 & 11.9 & 10.3\end{array}$
4.7
5.5 (Thru 1986)

1.1

0.5

0.5

0.5

0.5

3.3

0.3

0.3

0.3

0.7

0.2

0.1

0.3

0.8

1.0

1.0

1.0
0.8

1.0

1.2

9.0

7.2

5.9

$7.7 \quad 5.5$

16.6 (Thru 1985)

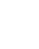

1.4

7.0

8.5 (Thru 1985)

$\frac{0.1}{6.4}$

1.5

5.0

5.0

$\begin{array}{ll}4.4 & 3.7\end{array}$

3.7

14.0 (Thru 1985)

6.4

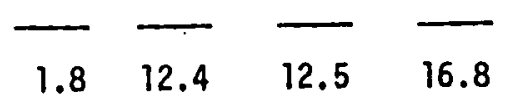

$\overline{19.0}$
18.0

52.9 (Thru 1985) 
PROGRAM PROJECTIONS (Continued)

SOLAR ELECTRIC APPLICATÏUNS (Continued)

\section{CAPITAL EQUIPMENT (BUDGET AUTHORITY)}

A. Solar Thermal

1. Central Receiver Power Plant

2. Solar Thermal Test Facilities

3. Solar Total Energy System

4. Distributed Collector Power Plant

5. Hybrid Solar Thermal Systens

Total

B. Solar Photovoltaic Conversion

Computers (less than $\$ 500.000$ )

Other 'Capital Equipment

Total

C. Wind Energy Conversion
(Dollars in Millions)

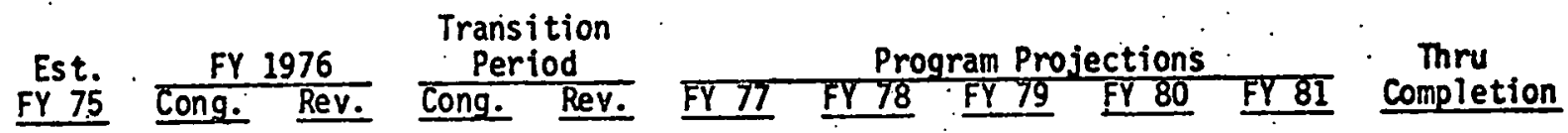

\begin{tabular}{|c|c|c|c|c|c|c|c|}
\hline & & 2.9 & $9 . \dot{6}$ & 10.6 & 5.1 & 5.0 & 50.0 \\
\hline \multirow[t]{2}{*}{0.7} & 0.2 & 8.5 & 3.0 & 2.0 & & & \\
\hline & & 0.5 & 2.0 & 3.3 & 9.1 & 12.7 & 27.0 \\
\hline . & & & $1 . \overline{9}$ & 9.0 & $7.0^{\circ}$ & 12.6 & 3.0 \\
\hline & & & & 3.0 & 11.0 & 19.0 & 27.0 \\
\hline 0.7 & 0.2 & 11.9 & 16.5 & 27.9 & 32.2 & 49.3 & 107.0 \\
\hline
\end{tabular}

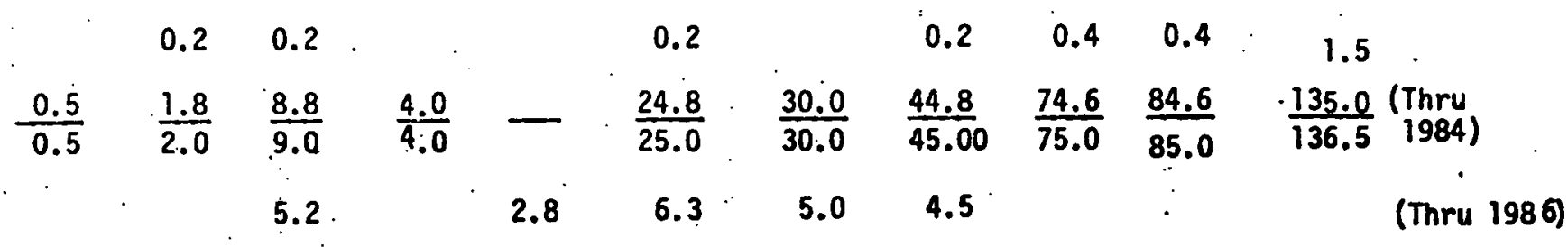


PROGRAM PROJECTIONS (Continued)

SOLAR ELECTRIC APPLICATIONS (Continued)

\section{PLANT (BUDGET AUTHORITY)}

A. Solar Thermal

1. Central Receiver Power Plant

2. Sol ar Thermal Test Facilities

3.. Solar Total Energy Systems

4. Distributed Collector Power Plant

5. Hybrid Solar Thermal Sys tems

Total

B. Solar Photovoltaic Conversion

๒ 1. Large-Scale Silicon-Material Plant

2. Large-Scale Plant for Automated

Production of Arrays

Total
(Dollars in Millions)

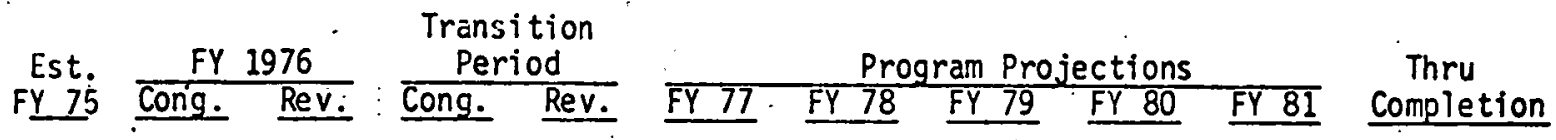

\begin{tabular}{|c|c|c|c|c|c|c|c|}
\hline \multirow[b]{2}{*}{0.8} & \multirow[b]{2}{*}{0.8} & 5.0 & 14.7 & 14.4 & 7.5 & 5.0 & 250.0 \\
\hline & & 16.5 & 2.0 & & & & . \\
\hline & & 2.8 & 4.4 & 9.8 & 14.6 & 13.9 & 60.0 \\
\hline & & & 6.0 & 4.0 & 10.0 . & 6.6 & 2.0 \\
\hline & & & & 4.0 & 8.0 & 12.0 & 17.0 \\
\hline .8 & 0.8 & 24.3 & 27.1 & 32.2 & 40.1 & 37.5 & 329.0 \\
\hline
\end{tabular}


PROGRAM PROJECTIONS' (Continued)

SOLAR ELECTRIC APPLICATIONS (Continied)

\section{PLANT (BUDGET AUTHORITY)}

(Continued)

C. Wind Energy Conversion

D. Ocean Thermai Energy Conversion

2. Land Based Test Facility

3. Sea Based Test Facility

4. Critical System Components Research \& Development

5. Prototype Floating Plant Design

6. Commercial Demonstration Plant Total
(Dollars in Millions)

\begin{tabular}{ccc} 
Est. & FY 1976 & $\begin{array}{c}\text { Transition } \\
\text { Period }\end{array}$ \\
\hline
\end{tabular} Program Projections
FY 77 FY 78 FY 79 FY 80

Thru

Completion

$$
\begin{array}{llllll}
7.0 \quad 18.0 & 29.0 \quad 36.0 & 13.5 \text { (Thru 1986) }
\end{array}
$$

$\begin{array}{llll}4.8 & 1.2 & 7.0 & 7.0\end{array}$

5.0

$5.1 \quad 12.0$

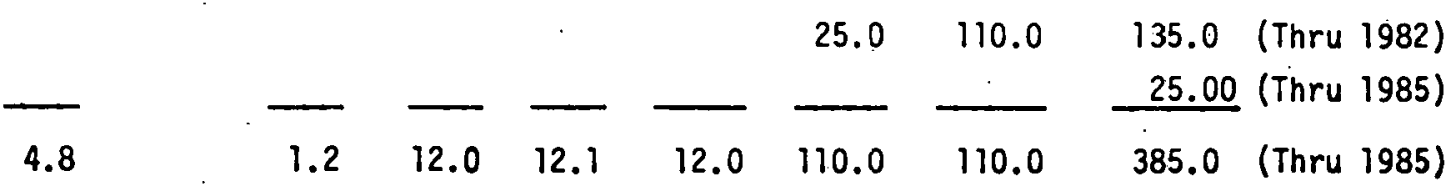




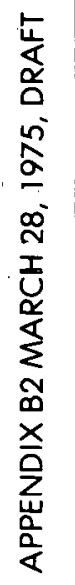


APPENDIX B2

MARCH 28, 1975, DRAFT Bं $2-1$ 
U. S. ENERGY RESEARCH AND DEVELOPMTET ADNIMISIRATION

PKOGRM DESCRI ITION

SOLAR ELECTRIC APPLICATIONS (SEA) PROGRAY

The obfective of the Solar Electric Applications (SEA) Program is to establish the technical and eccnomic feasibility ot

thermal, photovoltalc energy, wind energy and ocean thermal energy converston to produce electrictity. This will be occompllaled susa through reвearch, developme:lt and (iemonstration (RDóD) programs. These programs hilll result in the operation and cest of ilated stration plants in the near-term and the expanded use of commerclal plants in the mid and long-terms,

Government sponsorshlp. of the solar electric programs is required in the formative years to ensure that first-generation comestal planta can begin operating as early as possible. This sponsorship will also create the integrated governsent-1nstitutional-indiatrial basia 60 neceseary for the timely accomplishment of the overall program objectives. The apeciflc objectives, etrategy and approaches of the program aubunits comprising the Solar Electric Applications are ag follows,

\section{Solar. Thermal}

\section{Qutput}

The major objectives of solar thermal are: (1) to provide full aystem capabilfty for production of supplementary electrfe power and therinal power in the 1980 'a to conserve natural resources and (2) to provide a fuli aystem capability for total energy aystems (combined electrlc-thermal) for urban and rural communties, industrial/1nstitutional load centers and military bases at rates compet1tive with conventional energy sources. It $1 \mathrm{~s}$ anticipated that $40,000 \mathrm{MW}$ will be generated by the year 2,000 saving
320 million barrels of o1l per year.

\section{Assumptions}

Few fundamental technical limitations exist to prevent substantial application of solar thermal systems. The subprogram strategg is therefore to develop and demonstrate the economically competitlve capabilities of intermediate load (load-following) solar thermal power plants and solar total energy systems.

\section{Implementation}

Parallel contracts were awarded in 1975 for subsystem hardware for a load following/intermedlate load central receiver solar thermal electric power plant. These contracts include the developient and test of collector, recelver, and thermal storage concepts. A 5 NW Solar Thermal Test Facility w1ll be constructed in 1976 to test the subsystem hardiare. Construction of a I0MW Centraf Receiver P1lot Plant will be Initiated in 1977 and the plant integrated with a ut1lity grid in 1979 in cooperation with oeveral utilitiea. This pllot plant will be followed by a second generation pilot plant. A loom Demonstration Central Recelver Plant will te operational by 1985 to demonstrate technical and econocic viability. Simfiar develcẹients are planned for Total Energy Systems (combined electical-therma1), Distributed collector Systems and Hybrid Solar Thermal Systeas. 
U. S. ENERGY RESEARCH NVD DIVELOTMENT ADMEAISTRATION

PRGGRNI DESCRIPTION

\section{SOLAR ELECTRIC APPLICATIONS (SEA) PROGPAM}

\section{Continued}

Additional Research and Development studies covering collector/surface coatings, high temperature material development and solar thermal mission/system analystis are also planned.

\section{Solar Photovoltalc Conversion}

\section{Output}

A major near-term objective of the Solar Photovoltaic Converston is to stimulate a $U$. S. production capacity of soomw per year of slificon solar arrays at a price of less than $\$ 500$ per peak kilowatt by 1984 . The production of about $1 \%$ of the kiation's electrical power requirements in the 1990 to 2000 year period is anticipated.

\section{Assunptions}

Studies on promising concertration systems, operating and malitenance procedures, electrical storage and power conditioning, electric utility grid interfaces, and materials and device testing and standardization procedures, as well as studies of environmental, legal, socletal, institutional and other possible system constraints, will be conducted. A research and development program on alternative materials and low-cost devices will also be pursued.

\section{Implementation}

This will be accomplished by inftiating an annual procurement schedule for these arrays, ranging from 75 KW in FY 76 to 4 MW in FY 83. These arrays will be used in a blend of applications to generate electrical energy. The 1nitial $75 \mathrm{KW}$ (peak) of arrays will be used in cooperation with DOD on isolated military bases for demonstrations of energy self-sufficiency beginning in FY 76. If these demonst-ations prove successful, DOD is pjanning to buy substantial quantities of solar arrays for further applications starting at an annual level of $100 \mathrm{~kW}$ (peak) when array prices approach $\$ 5,000$ per peak $\mathrm{kilowatt}$, and at an applications starting at an annual level of $100 \mathrm{KW}$ (peak) when array prices appi

\section{Wind Energy Conversion}

\section{Output}

The objective of the Wind Energy Conversion is to accelerate the development and commercial use of economic rellable wind energy systems. Such systems have a minimal environmental impact, use a non-depletable energy source and are capable of producing significant energy outputs. The planned R\&D pregram would lead. to verification of successful systems by 1979 , several $100 \mathrm{MN}$ demonstrations by the early $1980 \mathrm{~s}$ and mass-proauction capabilities in excess of $15,000 \mathrm{MW}$ per year, at a cost of $\$ 250-\$ 300$ per rated kilowatt in the mid term. 
U. S. ENIERGY RESEARCH AND UEVEIOPMENT ADMINISTRITION

PEOGRLM D:SCREPTION

SOLAR ELECIRIC APPI:ICATIONS (SEA) PROGRAY

\section{Continued}

\section{Assumptions}

Since large-scale produrtion of Individual units that are small by utility standards (one MW per unit) 1s anticipated, the Federal Involvement in the development of sultable production facllities by the mid-1980s is a possible portion of the strategy.

\section{Implementation}

The otrategy of the wind energy conversion programs will be to develop a serles of experimental systens of 1ncreasing size and capability, supported by a research and technology base, leading to incrementally instailed multi-unit demonstration systems, fointly funded with users, in the early 1980s. While the emphasis is on electrical generation for electrical utility use, direct.heat, crop drying and fertilizer, amnufacturing, and fuel generation w11l also be demonstrated.

\section{Ocean Thermal Energy Convergion}

\section{Output}

The objective of Ocean Thormal Finergy Conversion (OTEC) 1e to demonetrate the feaglbllity of producing electric1ty through the acean temperature differences. W'ie feasibility of producing energy-intensive fertilizers and fuels from seawater and refining metals will also be investigated.

\section{Assumptions}

The commerclal acceptance of the sea-based ocean thermal conversicn stations requires the full-scale demonstration of system perfromance and cost estimates. Studies now in process indicate the technical knowledge is avallable for building an experimental prototype. The additional englneerling development required is of the adaptive and scale-up variety. The sclentific efforts paralleling this effort w1ll provide design optinization and reduce contruction costs. The program development emphasis has been placed on advancing a base11ne design incorporating low-r1sk design concepts and Incorporating design improvement only as thelr feasibility 18 documented. Th1s approach ensures that the overall progress of the program will not be 1 mpeded.

\section{Implementation}

The initial prototype is planned around the use of a full scale platform as hydrodynamic, thermodynamic mooring and environmental efrects do not lend therselves ta subscale testing. System design, critical component testing, material, and 1mplementation studies are In process. Land test fac1lities w111 be constructed in 1976 and sea test fac1lities in 1977. The prototype floating ocean thermal 


\section{1}

U. S. ENTRGY RESEARCH AND DEVELOPMENT ADMINISTRATION

PROGRAM IESCRIPTION

SOLAR ELECTRIC APPLICATIONS (SEA) PROGRAM

Continued

plant w11 be brought on line by 1985. Production of these and larget s1ze plants can then be accelerated in the intermediate-term. 
U. S. FNERGY RESEARCII AND DFVGIOPMENT ADMINISTRATION PROGRAM OUTHUTS

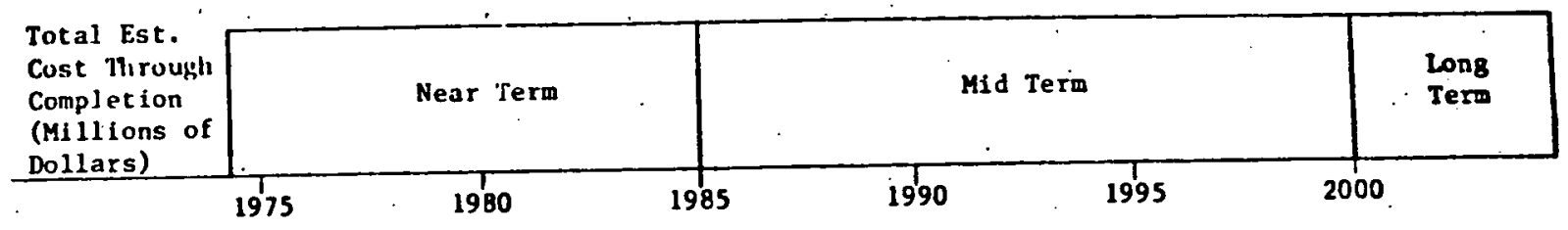

\section{Solar Electric Applicatlons}

A. Solar Thermal

$1251.1 \mathrm{a}$

$-40,000 \mathrm{MWe}$ generated saving 320 million

barrels of ofl per year

2000

Decision Polnts Anticipated

1. Central Rezelver Power flant

Dectston to bulld $10 \mathrm{rwe}_{\mathrm{e}}$ Pllot Plant

Dectaton to butld $100 \mathrm{MW}$

Demonstration Plant

Decision to build Firat Commerclal

Plant ( 100 to $\left.300 \mathrm{MH}_{\mathrm{e}}\right)$

$8(1 \mathrm{n}$ work)

2. Solar Thermal Test Faciidties

Declstón to bulld Central Recelver Pac1lity

Decision to bulld Distributed

Collector Fac1lity

$X$ (In work)

X(1976)

Q/Estimate through 1 year test of Initfal commerclal plants in 1987. 
U. S. FNERCY RESE?RCII LUD DFVIIOPMTNT ANMYSETRATION PROGRAM OLITITS

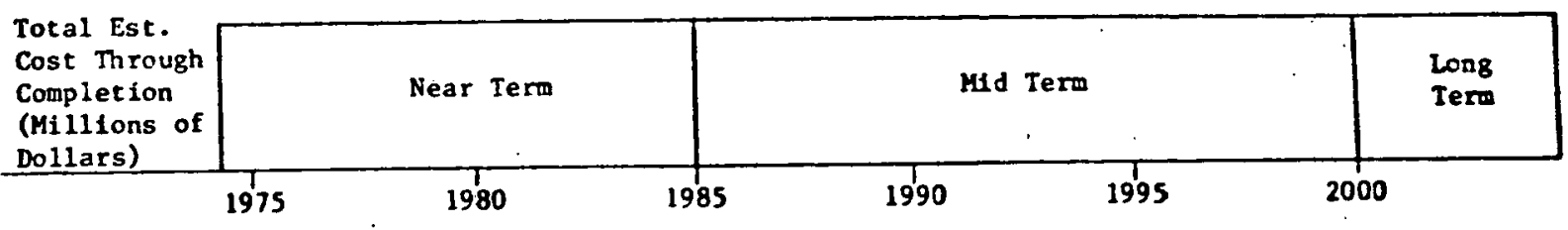

V. Solar Electric Application (cone.)

A. Solar Thermal (cont.)

Decision Points Anticipated (cont.)

3. Solar Total Energy Systems

Decision to build Pilot $200 \mathrm{KW}$

$\mathrm{MWW}_{\text {th }}$ (System $\# 1$ )

$x(1975)$

Decision to build Pllot 200kwe,

$2 \mathrm{MW}_{\text {th }}$ (System \#2)

X(1976)

Decision to bulld 10MW th (System 01 )

Demonstration Plant

$X(1979)$

Decision to build 10MWe. $200 \mathrm{MW}_{\text {th }}$

(System \#2) Demonstration Plant

4. Distributed Collector Power Plant

Dectsion to build IOW Pllat Plant

Dectsfan to bHfld 100MW Demonstration

Plant

X(1982) 
U. S. ENERGY RESEARCH AND DEVF.LOPMTNT ADMINISTRATION PROGRAM OLTPUTS

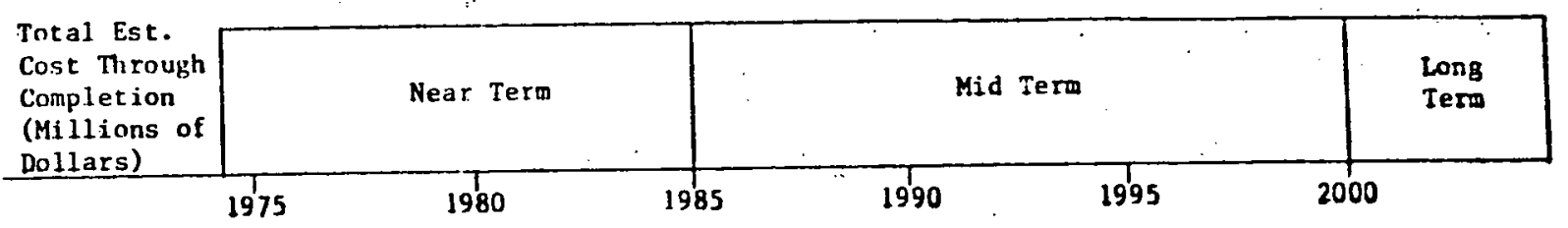

v. Solar Electric Application (cont)

A. Solar Thermal (cont.)

Decision Polnts Ant1cirated (cont.)

5. Hybrid Solar Thermal Systems

Decision to bulld inftial pilot plant

$X(1978)$

6. Research and Development

$X$ (In-work and through completion of program)

7. Program Support

$X$ (In- work and through completion of program)

Major Results Expected

1. Central Recefver Power Plant

$10 \mathrm{MN}$ Pllot Plant checked out and

operating

$\bullet(1979)$

$100 \mathrm{MW}$ Demonstration plent in

operation

Inftial Cominercial 100 to $300 \mathrm{MW}_{\mathrm{H}}$

Plants in operation

(1985)

(1987) 
U. S. ENERGY RESEARCH AVD DFVT.I OPMENT AENTNISTRATION

PRUGRAM OUTUUTS

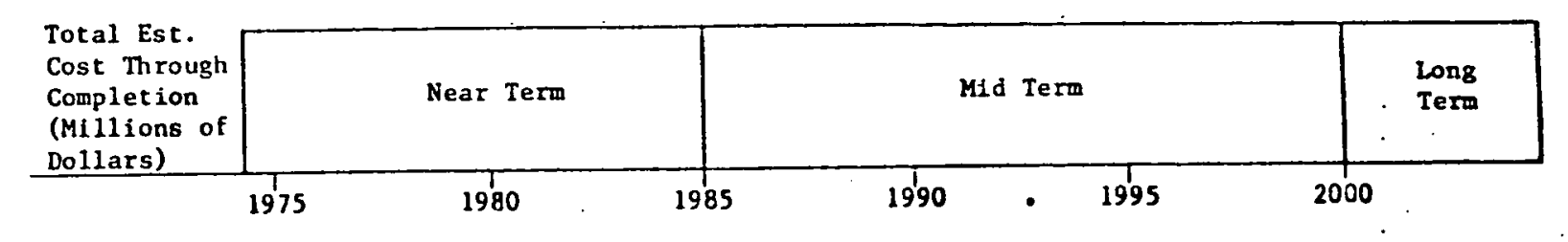

V. Solar Electric Application (cont.)

A. Solar Thermal (cont.)

Major Regilez Expected (conz;

2. Solar Thermal Test Fac1lities

Central Recelver Facility Operating

Distributed Collectur Facllity.

Operating

-(1977)

$\bullet(1978)$

3. Solar Total Energy Systems

$200 \mathrm{KW}_{\mathrm{e}}$, 2Mwth P1lot Plants

(Systems i \& 2) checked ont

and operating

$\bullet(1981)$

$10 W_{e}, 200 W_{\text {th }}$ Demonatration Plant

(System \#1) in operation

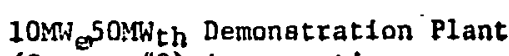

(System \#2) in operation

$\bullet$ (1985)

4. Distr1buted Collector Power Plant

10MW P1lot Plant checked out and operating

100NW Demonetration Plant in

operatsan

$0(1981)$

$\bullet$ (1986)

(1987) 
U. S. FNERGY RFSEARCH AND DEVELOPMENT ADMINISTRATION

PHOCRAM OUTIUTS

\begin{tabular}{l|ll|ll|l|l|}
$\begin{array}{l}\text { Total Est. } \\
\text { Cost Through } \\
\begin{array}{l}\text { Completion } \\
\text { (Millions of } \\
\text { Dollars) }\end{array}\end{array}$ & Near Term & & & Mid Term & $\begin{array}{l}\text { Lons } \\
\text { Term }\end{array}$ \\
\hline
\end{tabular}

v. Solar Electr1c Application (cont.)

A. Solar Thermal (cont.)

Major Results Expected (cont:)

5. Hybrid Solar Thermal Systers

Pilot Plant in 1 checked out and operat1ng

Pllot Plant 33 checked out and operating

$\bullet$ (1981)

$\cdot(1983)$ 
U. S. ENFRCY RESEARCH AND DFVELOPMENT ADMINISTRATION PRUGIRM OLITLLTS

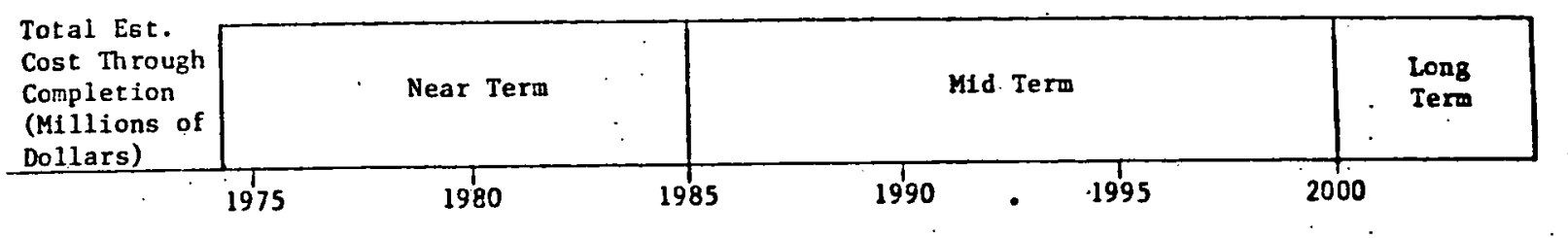

7. Solar Electicic Applications

B. Solar Fhotovoltalc Conversion $1468.7 \underline{a l}$

$-50,000 \mathrm{NW} /$ year produced at $\$ 100 / \mathrm{KW}$

Deciston Points Anticipated

1. Systems and Applications Derionstration Flan selected

Candidate Applications

selected

System Constrafuts Defined

Lo-Cost Stifcen Array Project

Accelerated-L1fecime Test-

Apfroach Selected

Silicon Material Process Selected

Automated Array Zabrication

Process Selected

S111con-Sheet Growth-Process

Selected

Go-Ahead on Construction of 500-MW

Fabrication Flant

$x(1976)$
$x(1976)$
$x(1977)$
$x(1977)$
$x(1977)$
$x(1978)$
$x(1979)$
$x(1979)$

E/ Include RDSD costs but not costs of manufacturing plants or Federal incentives for accelerated comercial production in mid and long terms. 
U. S. FNERCY RESEARCH AND DEVELOMMTNT IRMNISTRATION PROGRAM OUTPUTS

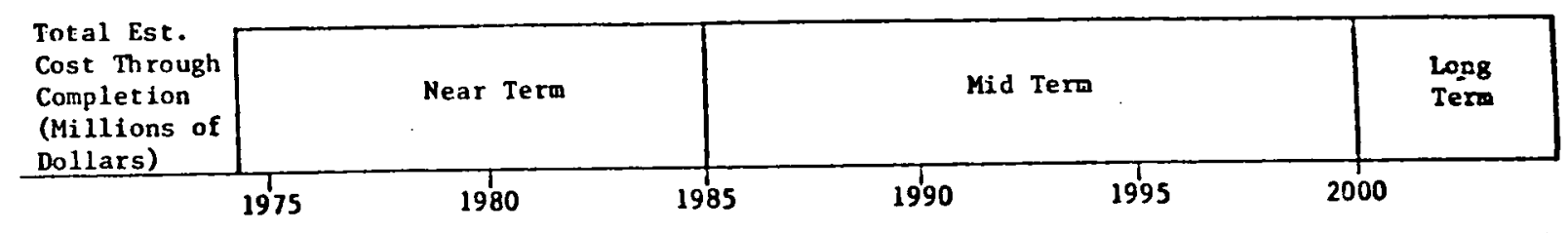

v. Solar Electric Applications (cont.)

B. Solar Photovoltalc Conversion (cont.)

Decision Polnts Anticipaled (cont.)

2. Low-Cost Sillicon Array Project (cont.)

Go-Ahead on continued Production for Demonstrations

$x(1976) \longrightarrow$ yearly

3. Concentrator Systems

\$5000/KW Design Selected

$\$ 250 / \mathrm{kW}$ Design Selected

$X(1976)$

$x(1981)$

4: Testing and Standards

Solar Array Performance Measure-

ments Approach Selected

$X(1976)$

Go-Ahead on Test and Standard-

Ization Facility

$X(1976)$

5. Research and Development

Ocher Candidate Matertala and

Devicea Selected for Further

Develapment

$x(1976) \rightarrow$ yearly

Ga-Ahead on Large-Scage Production 
U. S. ENERG: RESEARCH AND DEVELOPMEAT ADMIMISTRATYON PROGRAM OUTPLTS

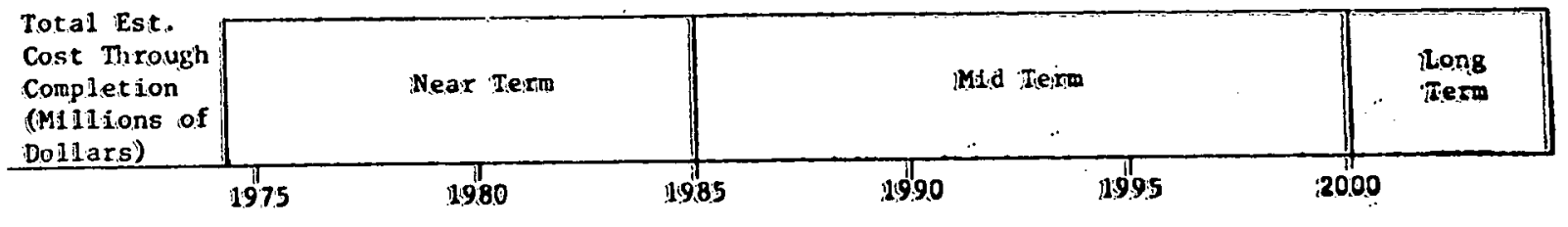

v. Solar Electric Applicattons (cont.)

B. Solar Photoyoltaic Conversion (cont.)

Decision Poirts Aaticlpated (cont.)

6. Energy Storage and Power Conditioning

Test Prograr Apfrooch Selected

$x(1977)$

F1nal Candidates Selected

$\mathrm{X}(1979)$

Mafor Resulis Expected

1. Systems and Applications

Systens and Sub-systems Specified

Operation of Demonstrations

Initiated: $75 \mathrm{KW} / 1976 ; 300 \mathrm{KW} / 1977$

500KW/1980; 4-MW/1981; 7-MW/1982;

$11-\mathrm{MW} / 1983$

$\bullet(1976) \longrightarrow \cdot(1983)$

2. Low-Cost Sillicon Array Project

P1lot-Plant for Sillcon-Material in Operation

$\bullet$ (1979)

Pllot-Piant for Large-Area Sillcoü-

Sheeta In Operation

Pllot-Plant for Automated-Production

of Arrays in Operation

$\bullet(1978)$

$-(1982)$

(1982) 
U. S. ENERCY RESEARCH AND DEVELOPMENT ADMINISTRATION PROGRAM OUTPUTS

\begin{tabular}{l|ll|ll|l}
$\begin{array}{l}\text { Total Est. } \\
\text { Cost Through } \\
\begin{array}{l}\text { Completion } \\
\text { (Millions of } \\
\text { Dollars) }\end{array}\end{array}$ & Near Term & & Mid Term & $\begin{array}{l}\text { Long } \\
\text { Term }\end{array}$ \\
\hline
\end{tabular}

y. Solar Electric Applications (cont.)

B. Solar Photovoltalc Conversion (cont.)

Major Results Expected (cont.)

2. Low-Cost Silicon Mrray Project (cont.)

Large-Scale Plant for Silicon-Material in Operation

red-

Large-Scale Plant for dutonated-

Production of SPC Arrags: $\$ 500 / \mathrm{KW}$

Delivery of SPC-Arrays for ERDA Demon-

stítions $75 \mathrm{KW} / 1976 ; 15 \mathrm{CKW} / 1977 ; 200 \mathrm{KW} /$

$1978 ; 500 \mathrm{KW} / 1979 ; 1-\mathrm{MW} / 1980 ; 2-\mathrm{MW} / 1981$;

芯.

$1978 ; 500 \mathrm{KW} / 1979 ; 1$
$3-\mathrm{MW} / 1982 ; 4 \mathrm{NW} / 1933$

$\bullet(1983)$
$\bullet(1984)$
.$(1976) \longrightarrow \cdot(1983)$

3. Concentrator Systems

Production and Operation of $\$ 5000 / \mathrm{KW}$

Systems

Production and Operation of $\$ 250 / \mathrm{KW}$

7. " Systems

$\bullet$ (1977)

4. Testing and Standards

Test and Standardization Facility

In Operation

Final Performance Spectflcations

Defined

$\bullet(1976)$

$.0(1978)$ 
U. S. ENFRGY RESEARCH AND DFVELOPMENT ADMINISTRATION

PROGRAM OHTPLTS

\begin{tabular}{l|ll|ll|l} 
Total Est. \\
$\begin{array}{l}\text { Cost Through } \\
\text { Completion } \\
\text { (Millions of } \\
\text { Dollars) }\end{array}$ & Near Term & & & Mid Term & $\begin{array}{l}\text { Long } \\
\text { Term }\end{array}$ \\
\hline
\end{tabular}

v. Solar Electric Applicatlcrs (cont.)

B. Solar Photovoltalc Conversion (cont.)

Major Results Fxpected (cont.)

5. Regearch And Developinent

Thin-Films Demenstrated at $10 \%$

Effictency

$\bullet(1980)$

Feasibllity of $\$ 100 /$ K.W Arraya

Demonstrated

$50,000 \mathrm{MW} /$ Year Produced at $\$ 100 / \mathrm{KW}$

(1992)

6. Energy Storage and Power Conditioning

Evaluation of Energy-Storage and

Power-Conditioning Completed

Prototype Testing Completed

-(1977)

Testing of Control Systems Completed

-(1978)

- (1983)

7. Assessment of Goals

Plant Owaership and Operation Plan Selected

$\bullet(1979)$ 
U. S. RERERIY RESFARCII AND MEVFIIOPMTANT NDMTNISTRATION PKIXIRM UITHIITS

\begin{tabular}{l|l|l|l|l|l}
$\begin{array}{l}\text { Total Est. } \\
\text { Cost Through } \\
\begin{array}{l}\text { Completion } \\
\text { (Millions of } \\
\text { Dollars) }\end{array}\end{array}$ & Near Term & & Mid Term & $\begin{array}{l}\text { Long } \\
\text { Term }\end{array}$ \\
\hline
\end{tabular}

v. Solar Electrlc Applicarions (Cont.).

c. Wind Energy Conversion

$-15,000 \mathrm{MW}$ e capacity achieved

Dectsion Polnts Anticloated

$$
274.7^{\mathrm{a} /}
$$
1. Research, Teçhnology and
Program Developuent

Inttial Appification Regions Selected

Recommendations on Fossible Incentives

X(1978)

2. Individual Farm WEC System

Decision to Implement Major

Farm Demonstration or

$x(1978)$

IncentIves Program

3. 100-KW Systems

Sttes Selected for Mod-1

Alternate Concepts Selected

Decision for Large Demonstration

$X(1976)$

$\mathrm{X}(1977)$

$x(1979)$

sincluäes demengtration costs but not the costs of manufacturing plants or Federal incentives for accelerated commerctal production 
U. S. ENERGY RESEARCH AND DEVELOPMENT ADMTNISTSATION PROGRAM OUTPUTS

\begin{tabular}{l|ll|ll|l} 
Total Est. \\
$\begin{array}{l}\text { Cost Through } \\
\text { Completion } \\
\text { (Millions of } \\
\text { Dollars) }\end{array}$ & Near Term & & & Mid Term & $\begin{array}{c}\text { Lonz } \\
\text { Term }\end{array}$ \\
\hline
\end{tabular}

v. Solar Electric Applications (Cont.)

C. Wind Energy Converstion (Cont.)

Dectsion Points Anticipated (cont.)

4. MW-Scale Sygtems

Sites Selected for Mad-1.

$\mathbf{x ( 1 9 7 6 )}$

Sites Selected for $\mathrm{Mcd}-2$

$\mathrm{x}(1977)$

Alternate Concepts SEllected

$\mathrm{X}(1977)$

5. Large-Scale, Multi-Untt WECS

Commt to Increnental

Construction - Inttial $10 \mathrm{Me}$

Comit to Ineremental

Construption = Initiel $100 \mathrm{NW}$

Compltment to Large=Ecale

Prokuetion

$x(1978)$
$x(1979)$
$\quad x(1997)$


U. S. ENFRC: RESEAKCH AND DF:SELOPMENT NOIIAISTRATION

PROGRAM OLTPUTS

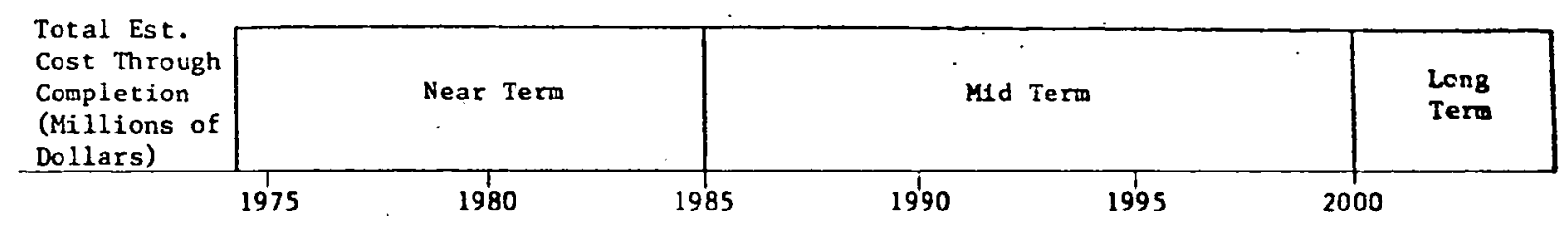

v. Solar Electric Applications (Cont.)

c. Wind Energy Converston (Cont.)

Mator Results Expected

1. Research. Technology and

Program Development

Intital Systems Analpses

Completed

Initial Env/Legal/Public

Acceptance Results

Site Selection Complezed

$$
\text { -(1976) }
$$

$\bullet(1977)$

$\bullet(1979)$

2. Individual Farm System

Initial Heating and Cooling

Practlcallty of Fertilizer

and Crop Drylng Determined

- (1977)

$\bullet(1979)$ 
U. S. ENERGY RESEARCH AND DEVELOPMENT NDMINISTRATION

PROGRAM OLTTFUTS

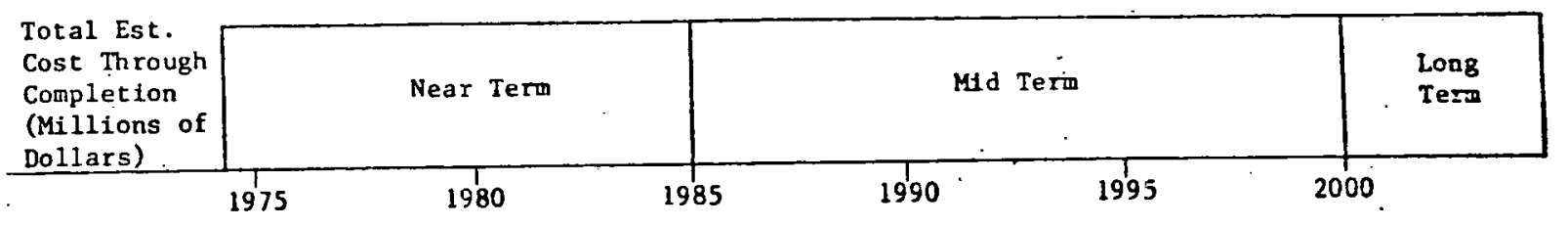

v. Solar Electric Applications (Cont.)

c. Wind Energy Conversion (Cont.)

Majoz reguiez Zizec:ed COne.;

3. $100 \mathrm{KW}$ Systema

Pabrication of Mod-1), Completed

Initial Tests Completed. Mod-0

Inftial Test Comple:ed on Mod-1

Practicality of Mod-2, Alternate Concefts Determined

4. MW-Scale Systems

Fabrication of Mod-1 Completed

Fabrication of Mod-2 Completed

Tests of Mod-1 and 2 Completed

Practical1ty Alternate Concepts Determined

$\cdot(1976)$
$\cdot(1977)$
$\cdot(1978)$
$\bullet(1979)$
$\cdot(1977)$
$\cdot(1979)$
$\bullet(1980)$
$\cdot(1981)$


U. S. ENERGY RESEARCH AND DEVELOPMENT ADMINISTRATION PROGRALS UUTPUTS

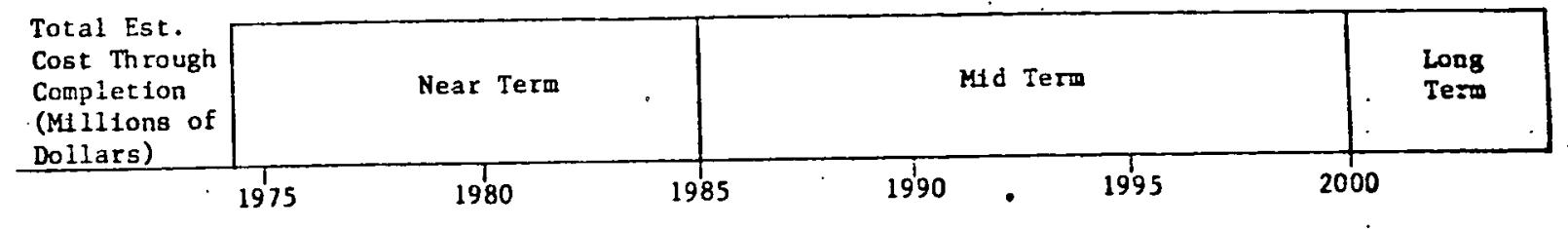

v. Solar Electric Applications (Cont.).

c. Wind Energy Converston (Eont.).

Metor Regulta Expected (Cont.)

5. Large-Scale, Mult1-Unit

Systems

Fabrfacton of 10-his

Demorgtration Completed

Fabrication of 1.00-NW

Demonstration Completed

Initial Tests of 10-NW

Demonstration Comp-eted

Inftial Tests of Fourth

100-MW Demonstrated

Completed

$\bullet(1979)$

(170 MW Capacity achieved)

Large-Scale Production

Started ${ }^{\text {a }}$

$\left(15,000 \mathrm{Mw}_{\mathrm{e}}\right.$ Capactity Achieved) $\mathrm{a} /$

$\bullet$ (1983)

$\bullet(1985)$

e/ Assumes major Fejeral Commltment and Incentives program.

Costs of WECS production and Fecieral incentives program are not included in funding shown. 
U. S. ENERCY RESEARCH AND IEVELCPMENT ADMINISTRATION PROGRAM OGI'UTS

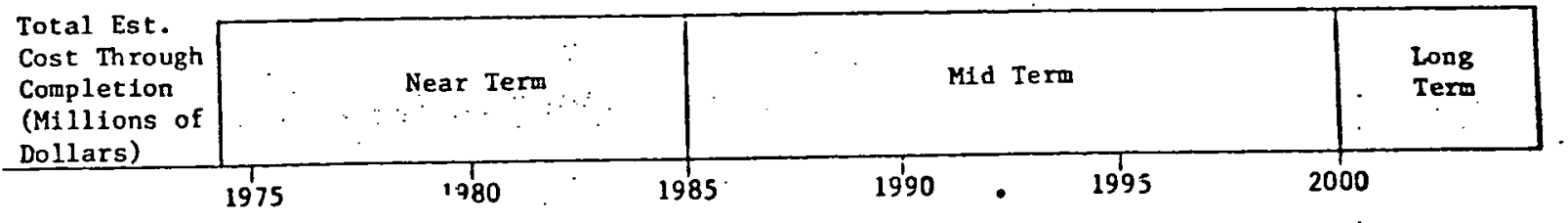

v. Solar Electric Applications (con't)

D. Ocean Thermal Energy Conversion

1058.6 al

-100 Niwe Commercial Demonazration

:(1985)

Model Operating

Dectsion Points Anticipated

1. Syster Studiea

Contrects to study tecinical

and economic feasibility of

ocean the rmal differenzes,

conduct engineering evalua-

tlons and develop test program. X(In work)

$\infty$
$N$
1
$N$

2. Land-Based Test Factlicy

Dectsion to Butld

$x(1975)$

3. Sea-Based Test Facility

Dectsion to Build

$X(1975)$

4. Critical System Components

Research and Development

Heat exchanger researci and

development contracts

Mod $O$ design and construction

$x$ (1n work)

contracts

$x(1975)$

Estimate through teet of $100 \mathrm{MW}$ Commercial Demongtration Hodel in 1995 
U. S. ENERGY RESEARCL AND DEVELOPNENT GOMTNISTRATION PRCGRAM OUTEUTS

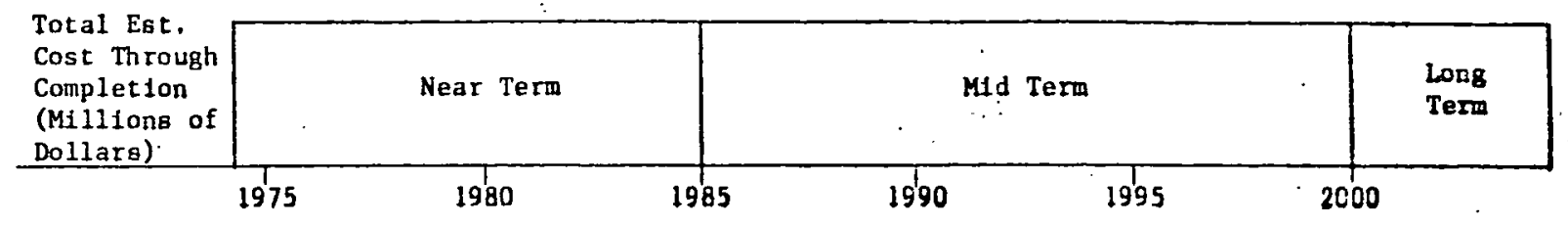

v, Solar Electric Applications (cont.)

d, Dcean Thermal Energy Convezsion (cont.)

- pecision Polnts Antictipazed (cont.)

4. Cfitical System Components Reseafch and Deyelopment (cont:)

Research and developnent con-

tracts on turbines, pumps,

anchorting/moortag/dynamic post-

fionine deep water pipe,

materials/corrosion biofouling

and screenting

$X(1975)$

Mod 1 design and conatruction

contracta

$X(1977)$

Systems engineering study of anchortng/moortng/dynam1c positioning

Contracte for prototype and

long-lead time pumpa, turbines

and plat form equipment

$x(1977)$

$x(1978)$

5. Prototype Floating Power Plant

Preliminary Design

Contracts (2) for $200 \mathrm{MW}$

Floatiag plant and $2 \mathrm{MW}$

Power Modile (hull ta be 
U. S. ENERCY RESEARCII RWD DEVE!OPMENT RDMTNISTEATION

PROGPAM OUTPLTS

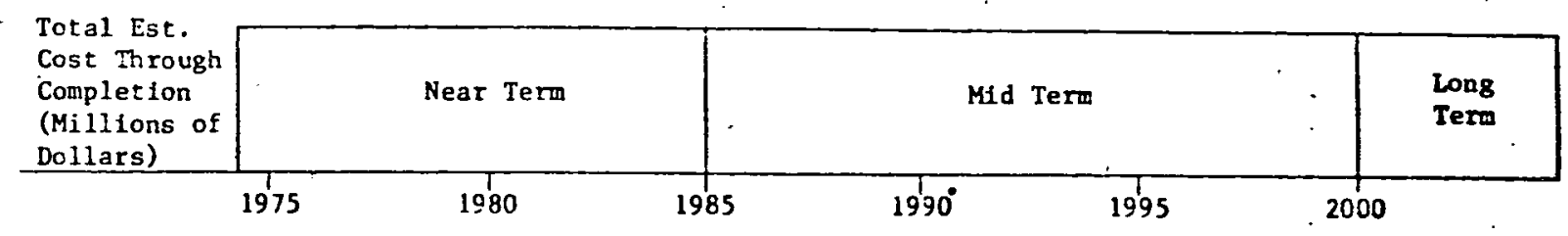

v. Solar Electric Applications (cont.)

D. Ocean Thernal Energy Conversion (cont.)

Decision Points Anticipated (cont.)

5. Prototype Floating power Plant (cont.)

full size, sur Eace anc sem1

submerstble options tc be

Investigated)

$X(1979)$

Contract for Purchase of Long-Lead

Time Materials and Equipment for

Prototype 100 Nive Floating Plant

Contract for Construction of Hull

and Initfal Power Module

$X(1980)$

$X(1981)$

6. Comercial Demonstration Power Station

Contract for Power Hodules for Commer-

clal Demonetration Model (Prototype

Hill will be Retroflited with new

Moduies)

$x(1982)$

7. Advanced Rscearch and Technology

Study Contracta ci Energy Dellvery,

Product MAX Impact and Siting. Thermal

Resourcea. and Legal Consideratione

(Inc? lidea provieion fof Maritime

Admintatraston agstatarice in establiah-

ing platform deotgn reçufrements) 
U. S. FNFRGY RFSEARCH AND DEVFiOPMENT ADMTNISTPATION PRUCIUMM UHFl'tils

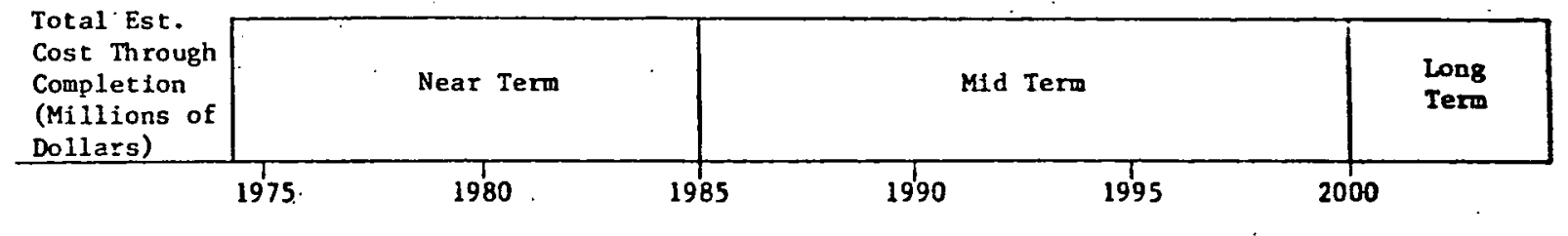

V. Solar Electric Applications (cont.)

D. Ocean Thermal Energy Conversion (cont.)

Decision Points Anticipated (cont.)

8. Other Renewable Energy Resources Studies

Contract to Review P.otential of Ocean

Currents, Waves, Tidos and Salinity

Gradients as Energy Source

$X(1975)$

Major Results Expected

1. System Studies (None 1centified)

0
$N$
$N$
$N$

2. Land-Based Teot Fac1lity

Fac1lity design completed

First phase of construction complete

Second phase of construction complete

$\bullet(1976)$

$\bullet$ (1977)

-(1978)

3. Sea-Based Test Fac1lity

Fac1lity Operating

$\bullet(1977)$

4. Critical System Componerts

Research and Development

Construction of Mod 0 designs

Inftiated 
U. S. ENERGY RESTARCH GVD DEVETSPRENT ADMINISTRATION PROGRAM OLIPUTS

\begin{tabular}{l|l|l|l|l|l|}
$\begin{array}{l}\text { Total Est. } \\
\text { Cost Through } \\
\text { Completion } \\
\text { (Millions of } \\
\text { Dollars) }\end{array}$ & Near Term & & Mid Term & $\begin{array}{l}\text { Long } \\
\text { Term }\end{array}$ \\
\hline
\end{tabular}

V. Solar Electric Afplicatlons (cont.)

D. Ocean Thermal Energy Convergion (cont.)

Major Results Expected (cont.)

4. Critical System Coniponents

Research and Deveiopment (cont.)

Construction of Mod $D$ designs

and tests underway

$\bullet(1976)$

Construction of Mod 1 designs

Initiated

$\bullet(1978)$

Systems engincering study of

anchortng/mooring/dyaamlc pos1-

tioning complete

Construction complete and tests

underway

(1)

-(1980)

5. Prototype Floating Power Plant

Preliminary Destgn of Prototype $100 \mathrm{MW}_{\mathrm{e}}$ and $25 \mathrm{MW}$ e Power Module

complete.

Deta1led Design of Prototype 100

MWe and 25MHe Power Mcalule complete.

$\bullet$ (1979)

$\bullet(1981)$ 
U. S. ENERGY RESEARCH AND DEVELGPMENT ADMIAIIETRATION

PROGRAM OL":?UTS

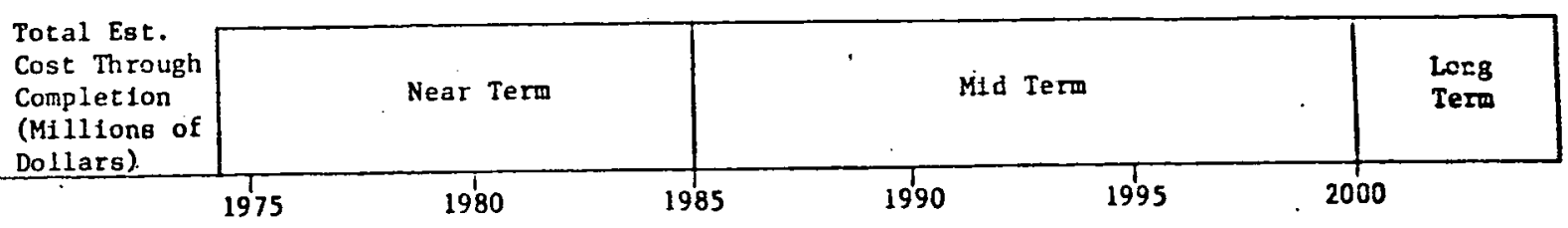

7. Sclar Electric Afplications (cunt.)

D. Ocean Thermal kinergy Conversion (cont.)

Mafor Resi:lts Expected icont.)

5. Prototype Floating Power Plant (cont.)

Test and Evaluation of Prototype

$100 \mathrm{NW}$ e Plant and 25Nive Power

Module Commences

$\bullet$ (1983)

6. Comercial Demonstration Power Station

Test of 100 Mwe Comsercial Demonstration

Model Containing Four Improved 25MWe

Power Nodules Retrofitted into

to

Prototype kull

$\bullet(1985)$ 
U. S. ENERGY RESETRCH AND.DEVELORSE!T ADMTNISTRATION

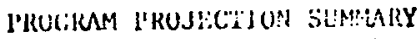

(Dollars in Milions)

SOLAR ELECTRIC APPLICATIONS (SEA) PROGRAY

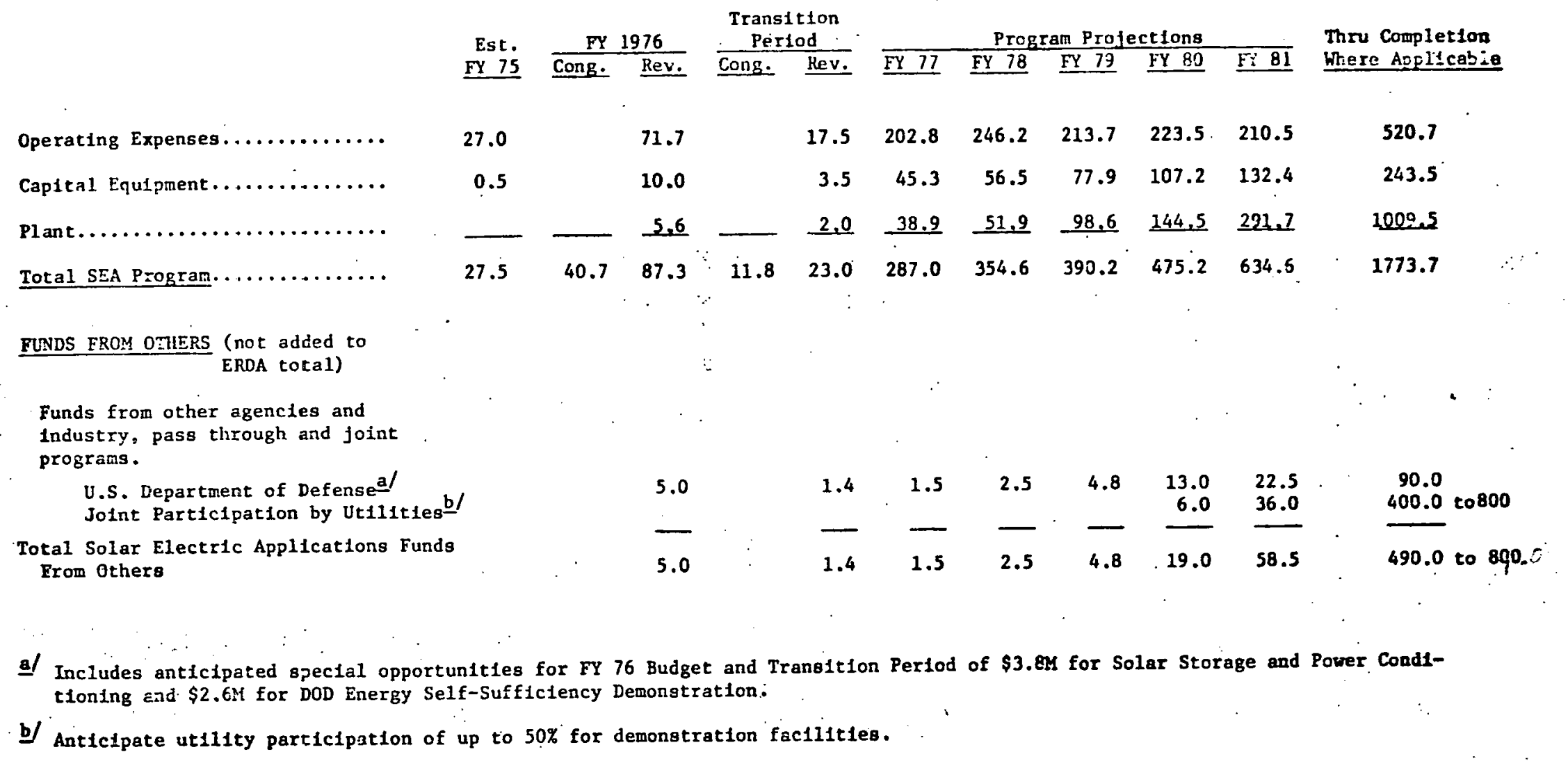


U. S. ENEKGY RESEARCH AND DEVËLOFMEMT ALMINISTRATION

PROGRA' PKCJECTIONS

Dollars in Millions)

SOLAR ELECTRIC APPLICATIONS (SEA) PRCGRAM

\section{OPERATING EXPENSES a}

A. Solar Thermal

B. Solar Photovoltaic Conversion

c. Wind Energy Conversion

D. Ocean Thermal Energ: Conversion

Total Solar Electric Application Operating

$\begin{array}{r}\text { Es } \\ \text { FY } \\ 10.0 \\ 7.5 \\ 6.5 \\ 3.0 \\ \hline\end{array}$

27.0
Est. FY 1976

Y 75 . Cong. Rev.

27.0

25.5

12.8

6.4

71.7
Transition

$$
\text { Period }
$$

Cong. Rev.

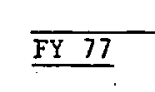

Progr

rogram Projections

6.1

46.0

6.4

124.3

54.1

FY 79

$F_{i}$

3.2

19.1

161.5

$116.5 \cdot 114.5 \quad 109.0$

1.8

13.4 .

17.1

12.911.

11.15 .1

$18.1 \quad 20.5 \quad 19.4$

$\begin{array}{llllll}17.5 & 202.8 & 246.2 & 213.7 & 223.5 & 210.5\end{array}$
Thru Complerion there ipplicable

$150.2 \mathrm{~b} /$

$307.5 \mathrm{cl}$

5.9 d

57.2 ef

N

b/ Through 1 year of operation of $100 \mathrm{MW}$ Demonstration plant in 1987

c/ Through large scale production decisions in 1984

d/ Through 1 year of operation of large scale system in 1986

ef Through I year of test of 100MWe Commerclal Demonstration Model in 1985 


\section{$c$}

PROGRAM PROJECTIONS (Contirued)

SOLAR ELECTRIC APH'ICATIONE (Cont1nued)

(Dollars in Millions)

\begin{tabular}{|c|c|c|c|c|c|c|c|c|c|c|c|}
\hline \multirow[b]{2}{*}{ CAPITAL ECUIPMENT (RUAGET R.UTHORITY) a $/$} & \multirow{2}{*}{$\begin{array}{r}\text { Est. } \\
\text { FY } 75 \\
\end{array}$} & \multicolumn{2}{|c|}{ FY 1976} & \multicolumn{2}{|c|}{$\begin{array}{l}\text { Transition } \\
\text { Period } \\
\end{array}$} & \multicolumn{5}{|c|}{ Program Projections } & \multirow{2}{*}{$\begin{array}{l}\text { Thru Complet1on } \\
\text { Where Apol1catie }\end{array}$} \\
\hline & & Cong. & Rev. & Cong. & rev. & $\overline{F i}$ & FY 78 & $\underline{F Y 79}$ & $\overline{F ! 80}$ & $\underline{F Y 11}$ & \\
\hline Consuters (1ess than $\$ 500,000$ ) & . & & 0.2 & & & 0.2 & 0.5 & 1.0 & 0.9 & 0.4 & 1.5 \\
\hline Other Equipment & 0.5 & & 9.8 & & 3.5 & 45.1 & 56.0 & 76.9 & 106.3 & 132.0 & 242.0 \\
\hline $\begin{array}{l}\text { otal Solar Electric Appli=at } \\
\text { Equípment }\end{array}$ & 0.5 & & 10.0 & & 3.5 & 45.3 & 56.5 & 77.9 & 107.2 & 132.4 & 243.5 \\
\hline
\end{tabular}


PROGRAM PROJEC:-ONS (Continued)

SOLAR EiEZTR:C APRETCGTIONS (Continued)

$\frac{\text { PLANT (BUEGET AUTHCRITY) }}{\text {. New Projects }}$

Solar Thermal b/

Central Recelver Power Plant 296.6

Solar Thermal Test Facilities 20.1

Solar Total Energy Systems 105.5

Distributed Collector Power

Plant

28.6

Hybrid Solar Thermal Systems

41.0

Solar Photovoltaic Conversion

Large-Scale Silicon-Material

$$
\text { plant }
$$

35.0

Large-Scale Plant for Automated

Production of Arrays

55.0

岕 : . . Hind Energy Conversion 155.5

Ocean Thermal Energy Coinversion

Land Based Test Faciltty

Sea Based Test Fac1lity
(Dollars in Millicns)
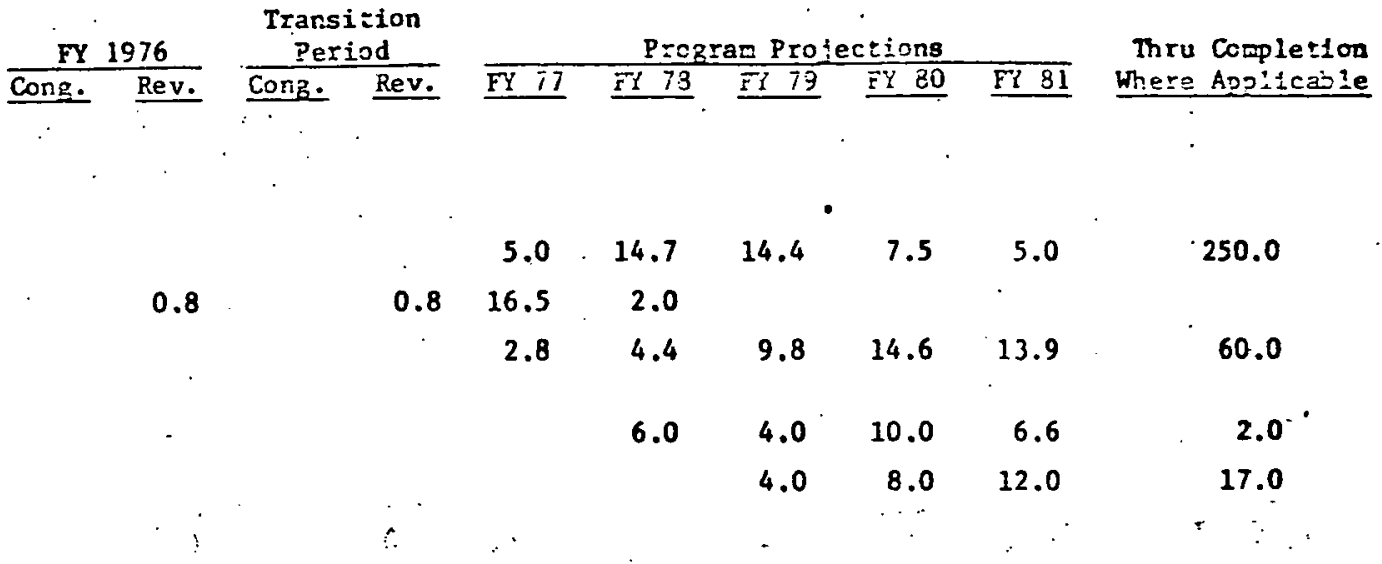

$\begin{array}{llll}14.7 & 14.4 & 7.5 & 5.0\end{array}$

250.0

$\begin{array}{lllll}4.4 & 9.8 & 14.6 & 13.9 & 60.0\end{array}$

$\begin{array}{lllll}6.0 & 4.0 & 10.0 & 6.6 & 2.0^{\circ}\end{array}$

$\begin{array}{llll}4.0 & 8.0 & 12.0 & 17.0\end{array}$

17.0

5.0

10.0

$9.124 .8 \quad 42.6 \quad 56.5 \quad 22.5$ 
PROGRAM PROJECTIONS (Continued)

SOLAR ELECTRIC APP:ICATIONS (Continued)

(Dollars in Millions)

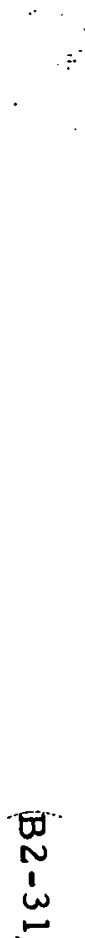

\section{Crant}

$$
\because
$$

PLANT (BUDCET AUTHORTIY) (cont.)
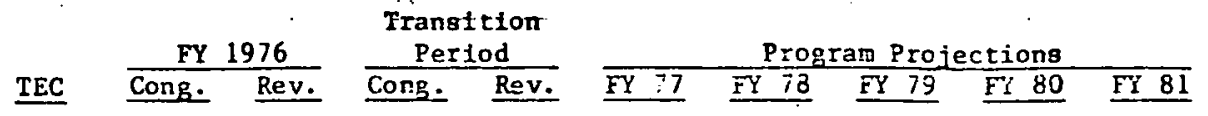

Thru Completion

Ocean Thermal Energy Converaton (cont.)

Critical System Components

Research \& Deveiopment

23.2

Prototype Floating Plan

Design

435.0

Commerctal Demonstration P1ant 417.5

Total Solar Electric Application

Plant

1642.7

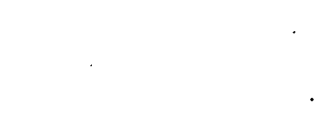

$6.6 \quad 16.6$

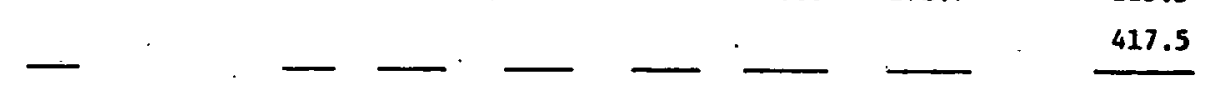

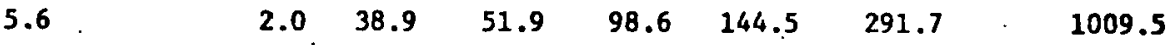

$\tilde{N}$
$\omega$
$\omega$

af All profect costs based on preliminary estimates, escalation factors over the period of congtruction schedule use FY 1975 as the base years: 1.11 for FY 76 and transition period, 1.22 for FY $77,1.3$ for FY $78,1.38$ for FY 79 , 1.47 for FY $80,1.57$ for FY 81 and 1.67 for following yeara.

b/ Ut1litieg are anticipated to contribute as much as $50 \%$ to demonetration and comercial plant developments. 


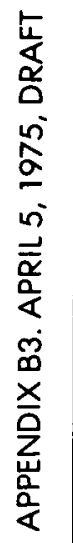




\section{APPENDIX B3}

APRIL 5, 1975, DRAFT

B3-1 
U. S. ENERGY RESEARCH AND DEVELOPMENT ADMINISTRATION
PROGRAM UESCRIPTION

SOLAR ELECTRIC APPLICATIONS (SEA) PROGRAM

The objective of the Solar Electric Applications Program is to establish the engineering and economic feasibility of using solar thermal, photovoltaic energ:, wind energy and ocean thermal energy conversion to produce electricity. This will be accomplished through research, 1985 and in a techoology and data base for implementation of commercial plants by the mid $1980^{\circ} 8$. Government sponsorship of the solar electric programs is required in the formative years to accelerate the development and implementation
of solar energy systems, shorten development times and overcome the lack of an industrial understanding of the potential of solar energy technology to meet U.S. energy needs. This sponsorship will create the integrated government-institutional-industrial basis. so necessary comprising the Soler Electric Applications are as follows:

Solar Thermal

Output

The objectives of solar thermal subprogram are: (1) to provide full system capab1lity for the production of supplementary electric and thermal power in the 1980 's to conserve natural resources and (2) to provide a full system capability for total energy syste (combined electric-thermal) for urban and rural communities, industrial/institutional load centers and military bases at rates
competitive wity conventional energy sources. It is projected that $40,000 \mathrm{~mW}$ of solar the rmal power plants will be constructed by competitive wit conventional energy sources. 2,000 saving about 320 milition barrels of petroleum per year.

\section{Assumptions}

No fundamental sechnical limitations exist to prevent substantial application of solar thermal systems. Solutions to engineering attractiveness of intermediate load and load-following solar thermal power plants and solar total energy systems.

\section{Implementation}

Parallel contracts are being awarded in 1975 for system concepts, subsystem hardware and for testing a locd following/1ntermediate load central recieiver solar thermal electric power plants. These include the design and test of collector, receiver, and therwal storage subsystems. A 5 . MW th $_{\text {Shar }}$ Solar Thermal Test Facility will be constructed in 1976 to test subsystem hardware. Construction a $10 \mathrm{MW}$ e Central Receiver P1lot Plant will be initiated 10 FY 1977 and the plant Integrated with a utilty grid in FY 1979 in

cooperation witt several utilities. A 100MWe Demonstration Central Recelver Plant will be operational by 1985 to demonstrate engineering and economic viability. Simllar demonstrations are planned for total energy systems (comb studies covering 


\section{U. S. ENERGY RESEARCH AND DEVELOPMENT ADMINISTRATION \\ PROGRAM DESCRIPTION}

SOLAR ELECTRIC APPLICATIONS (SEA) PROGRAM

\section{Continued}

collector/surface coatings, high temperature material developrent and solar themal mission/system analysis are also planned.

Solar Photovoltaic Conversion

Output

The major obje:tive o: the Solar Photovoltalc Conversion subprogram is to stimulate a $u$. S. production capacity of S00mw

per year of silicon solar arrays at a price of less than $\$ 500$ per peak kilowatt by 1985 . The production o 190,000 M 19 or about

$1 \%$ of the Nation's electrical power requirements by the 2000 year period is anticipated resulting in an equivalent annual savings of

\section{Assumptions}

Studies will be conducted on low cost silicon solar arrays, alternate materials, promising concentration systems, operating and maintenance procedures, electrical storage, power conditioning, electric utility grid interfaces, crystal growth, encapsulation and
mass production processes, as well as studies of environmental, legal, societal, institutional and other possible system constraints.

\section{Implementation}

This will be accomplished by the annual procurement of silicon solar arrays for generating electrical energy, ranging from $75 \mathrm{KW}$ in FY 76 to $4 \mathrm{MW}_{\mathrm{e}}$ in FY 83 . The initial $75 \mathrm{KW}_{\mathrm{e}}$ (peak) of arrays will be used in cooperation with DOD on isolated military bases for demonstrations of energy self-sufficiency beginning in FY 76 . Lf these demonstrations prove successful, DOD is planning to buy $\$ 5,000$ per peak kilowatt, and increasing to an applications starting at an annual level of $100 \mathrm{KW}$ (peak). when array prices approach expected ultimately to increase this annual rate of purchase 60 WWeak) for an array price near $\$ 2,500$ per peak kilowatt. DOD is Government procurement of approximately $250 \mathrm{KW}$ of solar arrays will be che prices of solar arrays continue to drop. A total and civilian applications. All subsequent ERDA array procurements will be directween ERD and DOD in 1977 and used in both milltary projects, leading to an $11 \mathrm{MW}$ e Demonstration in 1983. The rationale for the combined ERDAcell market in the FY 1976-1983 t1me period. 
Continued

U. S. ENERGY RESEARCH AND DEVELOPMENT ADMINISTRATION

PROGRAM DESCRIPTION

SOLAR ELECTRIC APPLICATIONS (SEA) PROGRAM

\section{Wind Energy Converstion}

output

The objective of the Wind Energy Conversion subprogram 1s to accelerate the development and the commercial implementation of reliable wind energy systems. Such systzms have a minimal environmental 1mpact, use a non-depletable energy source and are capable of producing 190s, and mass-jroduction capabilities in excess of 15,000 Mw per y or mid 1980 s.

\section{Assumptions}

The individual wind energy conversion units are small by utflity standards (two MW per unit). It is anticipated that the implementation strategy will call for the involvement of the Government in the development of suitable production facilities by the mid-i980s.

\section{Implementation}

The strategy of the wind energy conversion programs will be to develop a series of experimental systems of increasing size and capability, suppor users, in the early 1980s. While the emphasis is on the use by electrical utilities, direct heat, crop drying, fertilizer

Ocean Thermal Energy Conversicn

\section{Output}

The objective of the Ocean Thermal Energy Conversion (OTEC) subprogram is to demonstrate the technical and economic feasib1lity of producing electricity from the ocean temperature differences. The feasibility of producing energy-intensive fertilizers and fuels from seawater and the refining of metals will also be investigated.

\section{Assumptions}

The commercial acceptance of the sea-based ocean thermal conversion energy requires the full-scale demonstration of system performance and cost estimates. Studies now in process indicate the technical knowledge is available for building an experimental prototype. The 
U. S. ENERǴY RESEARCH AND DEVELOPMENT ADMINISTRATION

PROGRAM DESCRIPTION

SOLAR ELECTRIC APPLICATIONS (SEA) PROGRAM

\section{Continued}

additional engineering development required is of the adaptive and scale-up variety. The engineering efforts parallelinz this effort baseline design tncororaeing low-risk

This approach ensures that the overall progress of the program will not be impeded.

Implementation

The initial prototype is planned around the use of a full scale platform as hydrodynamic, thermodynamic mooring and environmental effects do not lend themselves to subscale testing. System design, critical component testing, material, and implementation studies are in process. Land test facilities will be constructed in 1976 and sea test facillties in 1977 . The 1 loating protocype ocean thermal plant will be brcught on line by 1983 and converted into a demonstration plant by 1985 . Production of commercial plants patterned af ter the denos

Programs established for conducting research and develooment in support of the National Solar Energy Progrem, disseminating Progran. assessment function are described in the Direct Solar Conversion Program. 
U. S. ENERGY RESEARCH AND DEVELOPMENT ADMINISTRATION

PROGRAM OUTPUTS

\begin{tabular}{l|l|l|l|l|}
$\begin{array}{l}\text { Total Est. } \\
\text { Cost Through } \\
\text { Completion } \\
\text { (Millions of } \\
\text { Dollars) }\end{array}$ & Neat Term & & Mid Term & $\begin{array}{l}\text { Long } \\
\text { Term }\end{array}$ \\
\hline 1975 & 1980 & 1985 & 1990 & 1995
\end{tabular}

v. Solar Electric Applications

A. Solar Theraal

$1251.1^{\mathrm{a}}$

40,000 MW capac1ty achleved

saving 326 million barreis of

petroleum annually.

Decision Polnts Anticipated

1. Central Receive: Power Plant

Decision to balld $10 \mathrm{MW}$ Pilot Plant $\quad X$ (in work)

Deciston to bnild $100 \mathrm{Mw}_{\mathrm{e}}$

Demonstration Plant

Decision to butld First Commercial

Plant ( 100 to $300 \mathrm{MW}_{\mathrm{e}}$ )

X(1982)

2. Solar Thermal Test Facilities

Decision to build Central Recelver

Facility

Decisicn to bild Distributed

$x$ (in work)

Collector Facfility

$X(1976)$

Program Output

To produce $1.5 \times 10^{8} \mathrm{MU}$ hours of electrical energy

a/Estimate through 1 year test of initial commerclal plants in 1987 . 
U. S. ENERCY RESEARCH AND DEVELOPMENT ADMINISTRATION PROGRAM OUTPUTS

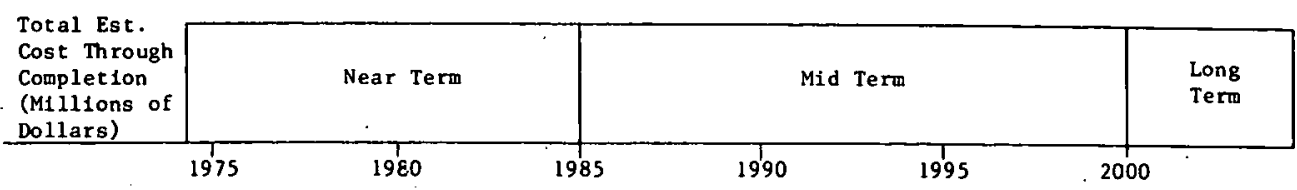

v. Solar Electric Apelicaticn (cont.)

A. Solar Thermal (cont.)

Decision Polnts Anticipated (cont.)

3. Solar Total Energy Systems

Dec1sion to build Pilot $200 \mathrm{KW}_{\mathrm{e}}$,
$2 \mathrm{MW}$ (System $\#$ ).

Decision to bulld Pllot $200 \mathrm{KW}_{\mathrm{e}}$

2MW th (System $\| 12$ )

Decision to buils 10MW th (System 1/?)

Demonstration Plant

Decision to builf lomwe, 200MW th

(System 02) Demonstration Plant

$x(1975)$

$\underset{w}{w}$

4. Distributed Collector Power Plant

Decision to build $10 \mathrm{MW}$ e Pilot Plant

Decision to builc $100 \mathrm{MW}$ e Demonstration

$x(1976)$

$x(1979)$

$x(1980)$

$x(1977)$

$X(1982)$ 
U. S. ENERGY RESEARCH AND DEVELOPMENT ADMINISTRATION PROGRAM OUTPUTS

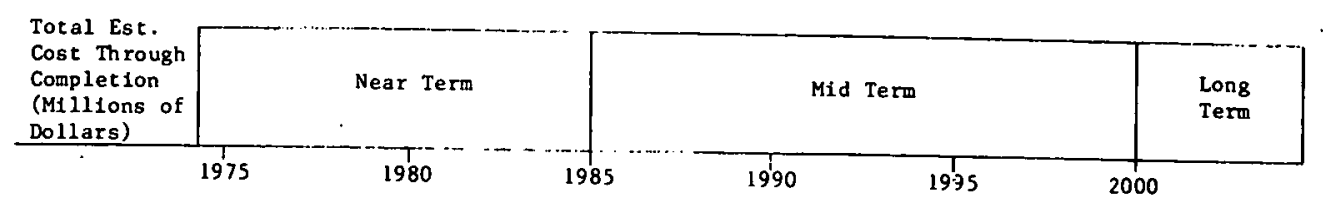

v. Solar Electric Application (cont)

A. Solar Thermal (cont)

Decision Pointe Ant1c1pated (cont)

5. Hybrid Solar Ttermal Systems

Decision to tuild initial pilot plant

$X(1978)$

6. Research and Development

7. Program Support

Major Results Expected

1. Central Receiver Power Plant

10mwe P1lot Plant checked out and operating

$100 \mathrm{MW}$ e Demons:ration plant in

operation

Initial Comme:cial 100 to 300

Plants in ope:ation

$\bullet(1985)$

$X$ (In-work and through completion of program)

$x$ (In-work and through zompletion of program) 
U. S. ENERGY RESEARCH AND DEVELOPMENI ADMINISTRATION PROGRAM OUTPUTS

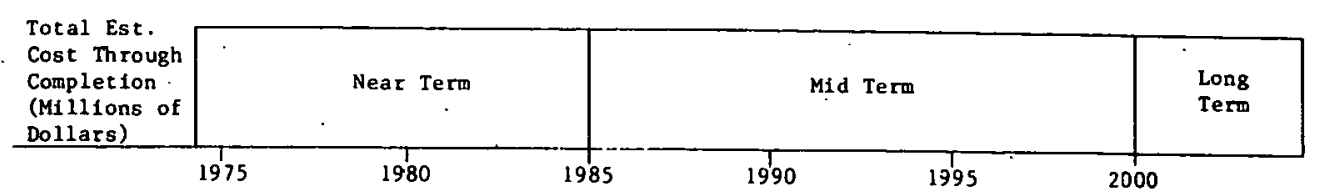

v. Solar Electric Application (cont.)

A. Solar Thermal (cont.)

Major Results Expzcted (cont)

2. Solar Thermal Tes: Fac1lities

Central Receiver Fac1lity Operating •(1977)

Distributed Coliector Fac1lity
Operating

3. Solar Total Energy Systems

$200 \mathrm{KW}_{\mathrm{e}}$, 2MW $\mathrm{Mh}_{\text {th }}$ Pjlot Plants

(Systems $1 \& 2$ ) checked out

and operating

$10 \mathrm{MW}_{\mathrm{e}}$, 200MW th Lemonstration Plant

(System III) in cperation

10MW , 50MWth Demonstration Flant

(System 12) in operation

4. Distributed Coilector Power Plant

10MW Pllot Plan: checked out

and operating

$\bullet$ (1981)

$100 \mathrm{MW}$ e Demonstration Plant in

operation 
v. Solar Electric Application (cont)

U. S. ENERGY RESEARCH AND DEVELOPMENT ADMINISTRATION PROGRAM OUTPUTS

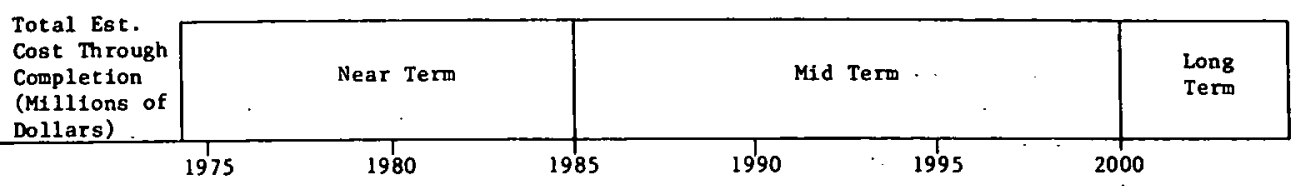

A. Solar Thermal (cont)

Major Results Expected (cont)

5. Hybrid Solar Thermal Systems

P1lot Plant "I checked out and operating

P1lot Plant 3 checked out and operating

$\bullet(1981)$

•(1983) 
U. S. ENERGY RESEARCH AND DEVELOPMENT ADMINISTRATION PROGRAM OUTPUTS

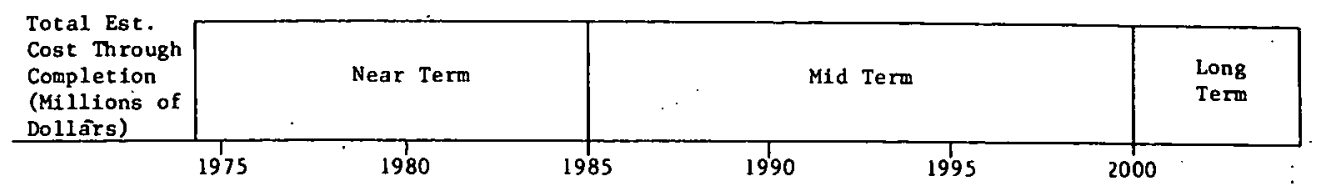

v. Solar Electric Applications (cont)

B. Solar Photovoltalc Jonversion

1252.1 a

$190,000 \mathrm{MW}$ (peak) capacity achleved saving

million bar:els of petroleum annually.

Decision Po:nts Ant1cipated

1. Systems and Applications

Demonstration Plan selected

$(176.9)$

Candidate Applications

System Constralnts Defined

$\mathrm{X}(1977)$

$X(1978)$

2. Low-Cost Siltcon Array Project (700.4)

Accelerated-Lifetime Test-

Approach Selected

$X(1978)$

Silicon Material Process Selected

$x(1978)$

Automated frray Fabrication

$x(1979)$

S111con-Sheet Growth-Process

$x(1979)$

Selected

$\mathrm{X}(1980)$

Go-Ahead on Construction of $500-\mathrm{MW}$

$x(1980)$

a/ Include RD\&D costs thru 1985 but not costs of manufacturing plants or Federal incentives for accelerated commercial production in mid and long terms. 
U. S. ENERGY RESEARCH AND DEVELOPMENT ADMINISTRATION ROGRAM OUTPUTS

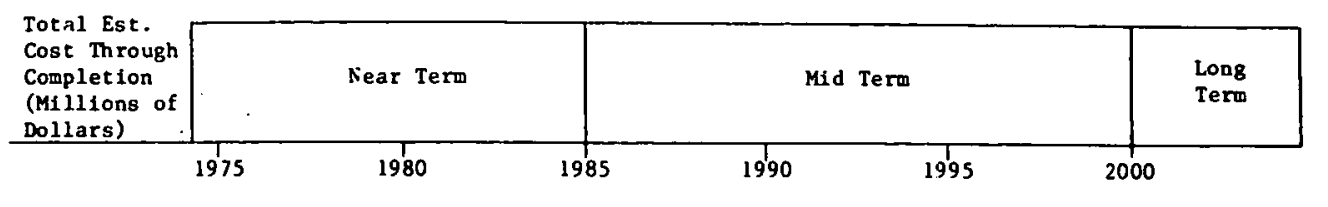

V. Solar Electric App11cations (cont)

B. Solar Photovoltalc Conversion (cont) Decision Points Anticipated (cont)

2. Low-Cost Sillicon Array Profect (cont) Go-Ahead on contirued Production for Demonstrations

$x(1976) \longrightarrow$ yearly

3. Concentrator System

(49.7)

$\$ 5000 / \mathrm{KW}$ Design Selected

$\$ 2000 / \mathrm{KW}$ Design Selected

$\$ 1000 / \mathrm{KW}$. Design Selected
$\$ 250 / \mathrm{KW}$ Des1gn Selected

4. Testing and Standards

Solar Array Perfornance Measure-

ments Approach Selected

Go-Ahead on Test S:andard-

1zation Facility

5. Research and Development (114.3)

Other Candidate Marerials and

Devices Selected för Further

Development.

$x(1977)$

$x(1978) \times(1980)$

(1980) $\times(1982)$

Go-Ahead on Large-5cale Production

$X(1976) \longrightarrow$ yearly 
v. Solar Electric Applications (cont)

U. S. ENERGY RESEARCH AND DEVELOPMENT ADMINISTRATION PROGRAM OUTPUTS

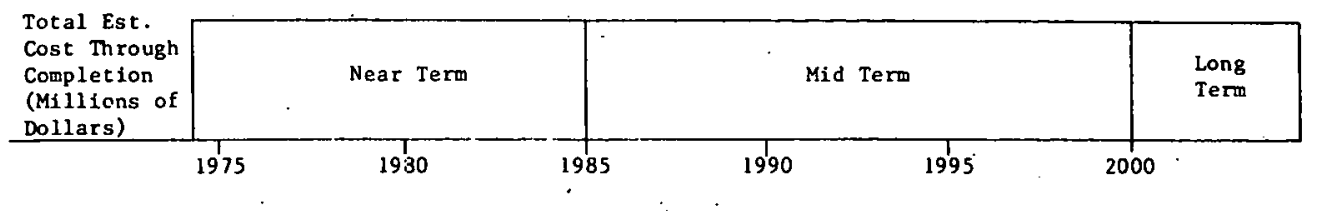

B. Solar Photovoltaic Conversion (cont)

Deciston Points Anticipated (cont)

6. Energy Storage and Power Conditioning

Test Program Approach Selected

$(168.3)$

Final Candidates Selected

$x(1977)$

$x(1979)$

Major Results Expected

1. Systems and Applications

Systems and Subsystens Specified

Operation of Demonst:ations

Intt1ated: $75 \mathrm{KW} / 1975 ; 300 \mathrm{KW} / 1977$;

$500 \mathrm{~kW} / 1978 ; 1 \mathrm{MW} / 1979 ; 2 \mathrm{MW} / 1980$

4MW/1981; 7MW!1982; IIMW/1983

(176.9) $\bullet(1979)$

. Low-Cost Silicon Array Project

Pilot-Plant for Silizon-Material in Operation

Pllot-Plant for Large-Area SiliconSheets in Operation

Pilot-Plant for Autonated-Production

of Arrays in Operation

(700.4)

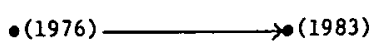

$\begin{array}{cc}\bullet(1980) & \cdot . \\ & \bullet(1983)\end{array}$

•(1983) 
U. S. ENERGY RESEARCH AND DEVELOPMENT ADMINISTRATION PROGRAM OUTPUTS

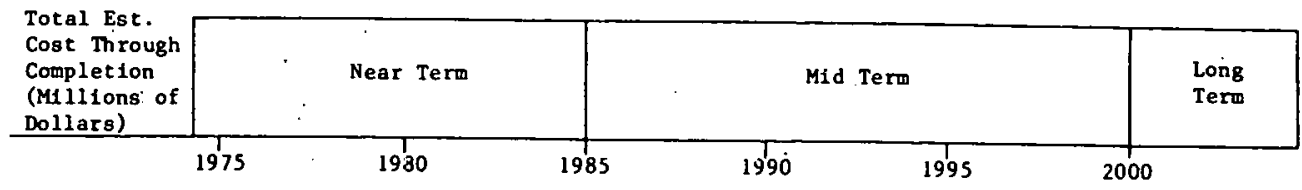

v. Solar Electric Applications (cont)

B. Solar Photovoltatc Conversion (cont)

Major Results Expected (cont.)

2. Low-Cost S1licon Array Profect (cont)

Large-Scale Plant for Silicon-Material In Operation

Large-Scale Plant for Automated-

Production of SPC Arrays: $\$ 500 / \mathrm{KW}$

Delivery of SPC-Arrays for ERDA Demon-

1978; 500

3MW/1982; 4MW/198

3. Concentrator Systems

Production and Operation of $\$ 5000 / \mathrm{KW}$ Systems

Production and Operation of $\$ 2000 / \mathrm{KW}$

Systems

Production and Operation of $\$ 1000 / \mathrm{KW}$ Systems

Production and Operation of $\$ 250 / \mathrm{KW}$ Systems

$\bullet(1984)$

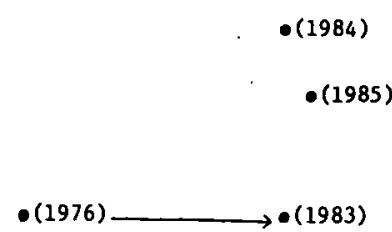

$\bullet(1978)$

$\bullet(1980)$

$\bullet$ (1982)

$\bullet(1985)$ 


\section{v. Solar Electric Applications (cont)}

U. S. ENERGY RESEARCH AND DEVELOPMENT ADMINISTRATION ROGRAM OUTPUTS

\begin{tabular}{l|l|l|l|l|}
$\begin{array}{l}\text { Total Est. } \\
\text { Cost Through } \\
\text { Completion } \\
\text { (Millions of } \\
\text { Dollars) }\end{array}$ & Near Term & & Mid Term & $\begin{array}{l}\text { Long } \\
\text { Term }\end{array}$ \\
\hline 1975 & 1980 & 1985 & 1990 & 1995
\end{tabular}

B. Solar Photovoltalc Conversion (cont)

Major Results Expec:ed (cont)

4. Testing and Standar.1s Test and Standardization Facility In Operation

$\bullet(1976)$

Final Performance Specifications

Defined

$\bullet(1978)$

5. Research and Develomment

Thin-Films Demons:rated at $10 x$ Efficiency

Peasibility of $\$ 100$ to $\$ 300$ pe

KW Arrays Demonst:ated

$50,000 \mathrm{MW} /$ Year Produced at $\$ 100$ to $\$ 300$ per $k$ ?

6. Energy Storage and Zower Condittoning

Evaluation of Ene:gy-Storage and

Evaluation of Ene-gy-Storage
Power-Conditioning Completed

Prototype Testing Completed

Testing of Control Systems Completed

and Subsys:em Har.wware Developed

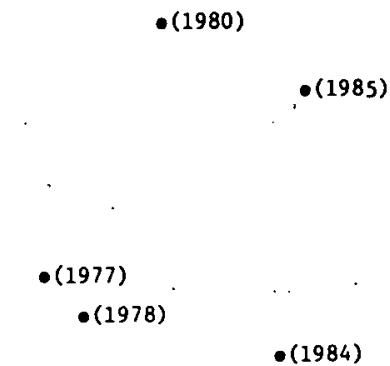

(1995) 
U. S. ENERGY RESEARCH AND DEVELOPMENT ADMINISTRATION PROGRAM OUTPUTS

\begin{tabular}{l|l|l|l|l|l|}
$\begin{array}{l}\text { Total Est. } \\
\text { Cost Through } \\
\begin{array}{l}\text { Completion } \\
\text { (Millions of } \\
\text { Dollars) }\end{array}\end{array}$ & Near Term & & \multicolumn{2}{|c|}{ Mid Term } & $\begin{array}{l}\text { Long } \\
\text { Term }\end{array}$ \\
\hline
\end{tabular}

v. Solar Electric Applicat1ons (cont)

B. Solar Photovoltaic Conve-sion (cont)

Major Results Expected (cont)

7. Assessment of Goals (6.1)

Plant Ownership and Operation Plan

Selected

$\bullet(1980)$ 
U. S. ENERGY RESEARCH AND DEVELOPMENT ADMINISTRATION PROGRAM OUTPUTS

v. Solar Electric Applications (Cont.)

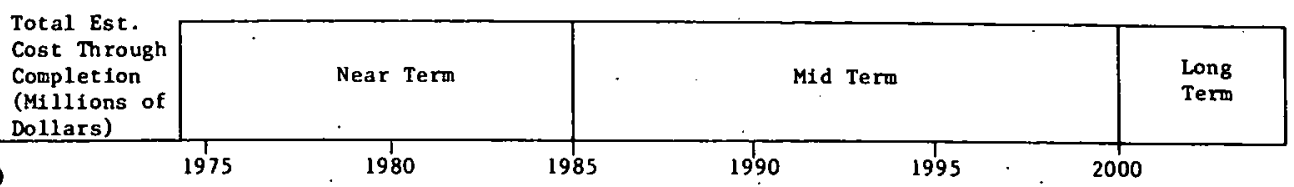

c. Wind Energy Converston (Cont.) $15,000 \mathrm{MW}$ rated capacity achieved million barrels of petroleum annualiy. $279.9 \mathrm{a} /$

Decision PoInts Anticipated

1. Research, Technology and Program Develiopment Inftial Application Regions Selected Recommendattons on Posstble

2. Ind1vidual Parm WEC Spatem Dectsion to Implement Major Parmi Demonstration or Incentives Program

(39.3)

100-KW Systene

Sites Selected for Mod-1

Alternate Concepts Selected

Decision for Large Demonstratio

(7.3)

$x(1978)$

(13.2)

$x(1976)$

$x(1977)$

X(1979)

a/ Includes demonstration costs but not the costs of manufacturing plants or Federal incentives for accelerated commercial production 
U. S. ENERGY RESEARCH AND DEVELOPMENT ADMINISTRATION PROGRAM DUTPUTS

\begin{tabular}{l|ll|ll|l|}
$\begin{array}{l}\text { Total Est. } \\
\text { Cost Through } \\
\text { Completion } \\
\text { (Millions of } \\
\text { Dollars) }\end{array}$ & Near Term & & \multicolumn{2}{|c|}{ Mid Term } & $\begin{array}{r}\text { Long } \\
\text { Term }\end{array}$ \\
\hline 1975 & 1980 & 1985 & 1990 & 1995 & 2000
\end{tabular}

v. Solar Electric Applications (Cont.)

c. Wind Energg Convezsion (Cont.)

Decision Poincs Ant1c1pated (Cont.)

4. MW-Scale Systems

Sites Selected for Mod-1

sites Selected for Mod-

Alternate Ccncepts Selected

5. Large-Scale, Mult1-Un1t WECs

Commit to Incremental

Construction - Initial $10 \mathrm{M}$

Commit to Incremental

Construction - Initial $100 \mathrm{MW}_{\mathrm{e}}$

Commitment to Large-Scale

Production
(33.7)

$x(1976)$

$x(1977)$

$x(1977)$

$(186.4)$

$X(1978)$

$x(1979)$

$X(1981)$ 
J. S. ENERGY RESEARCH AND DEVELOPMENT ADMINISTRATION PROCRAM OUTPUTS

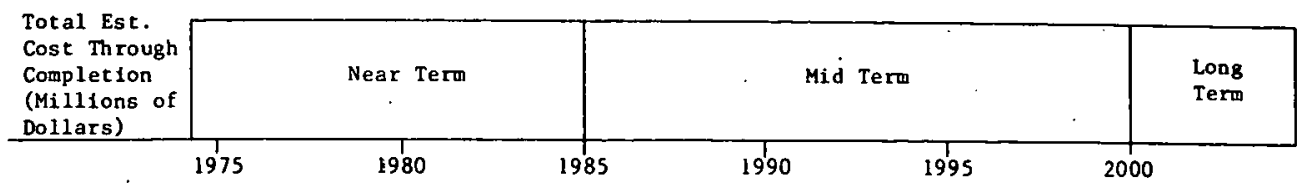

v. Solar Electr1c Applications (Cont.)

C. Wind Energy Conversion (Cont.).

Major Results Expected

1. Research, Technology and

Program Development

Inttial Syst:ems Analyses

Completed

-(1976)

Initial Env/Legal/Publtc

Acceptance Results

Site Selection Completed

- (1977)

$$
\bullet \text { (1979) }
$$

2. Individual Farn System

Inttial Heating and cooling

Practicality of Fert1lizer

$\cdot(1977)$

and Crop Dryfing Determined

$\bullet$ (1979) 
U. S. ENERGY RESEARCH AND DEVELOPMENT ADMINISTRATION PROGRAM OUTPUTS

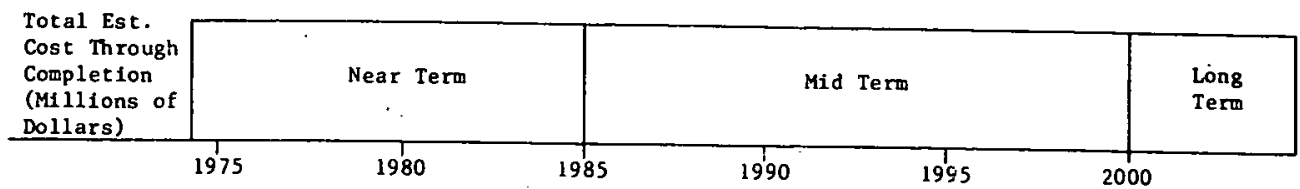

v. Solar Electric Applications (Cont.)

c. Wind Energy Conve:sion (Cont.)

Major Results Expected (Cont.)

3. $100 \mathrm{kw} \mathrm{Systems}$

Pabrication of Mod-0,

Completed

Inttial Tests Completed,

Mod-0

Intial Test Completed

on Mod-1

Practical1ty of Mod-2,

Alternate Concepts

Deteruined

$\bullet(1976)$

$\bullet$ (1977)

$\bullet(1978)$

-(1979)

4. MW-Scale Systexs

Pabrication of Mod-1

Completed

Pabrication of Mod-2

Completed

$\bullet(1977)$

Tests of Mod-1 and

Completed

Practicality Alternate

Concepts Determined$$
\text { -(1979) }
$$

$\bullet(1980)$

$\bullet$ (1981) 
v. S. ENERGY RESEARCH AND DEVELOPMENT ADMINISTRATION PROGRAM OUTPUTS

\begin{tabular}{l|ll|ll|c|}
$\begin{array}{l}\text { Total Est. } \\
\text { Cost Through } \\
\text { Completion } \\
\text { (Millions of } \\
\text { Dollars) }\end{array}$ & Near Term & & & Mid Term & $\begin{array}{l}\text { Long } \\
\text { Term }\end{array}$ \\
\hline
\end{tabular}

v. Solar Electric Applications (Cont.)

c. Hiad Energy Conversion (Cont. 2

Ma'for Results Expected (Cont.)

5. Large-Scale, Multi-Unit

-. Systems

Pabirication of 10-MW

Demonstration Completed

Fabrication of 100-KW

Demonstration Completed

Inftial Tests of 10-MW

Demonstration Completed

Inftial Tests of Pourth

100-IW Demoastrated

Completed

(170 MW $\mathrm{e}$ Cajacity Achieved)

Large-Scale Production

Started

$(15,000 \mathrm{MW}$ Capacity Achieved)

$\bullet$ (1979)

$\bullet(1981)$

$\bullet$ (1981)

$\bullet$ (1985)

$\bullet(1981)$

-(1983)

$\bullet$ (1985)

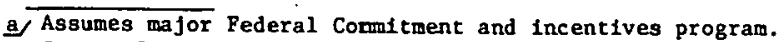

Costs of WECS production and Pederal incentives program are not included in funding shown. 
U. S. ENERGY RESEARCH AND DEVELOPMENT ADMINISTRATION PROGRAM OUTPUTS

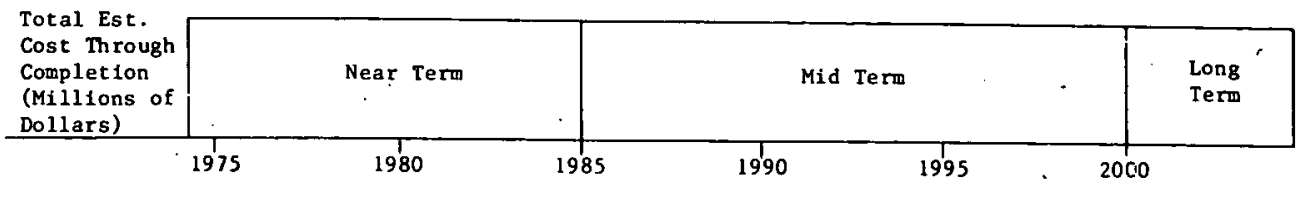

V. Solar Electr1c Applicaricns (con't)

D. Ocean Thermal Energy Conversion 1058.6 a/

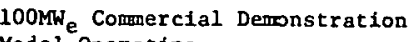
Model Operating

Decision Points Aaticipated

1. System Studies

Contracts to study technical and

economic feasibility of ocean

thermal differences, conduc

engineering evaiuations and

$X$ (In work)

2. Test Facilfties

Decision to Build

$x(1975)$

3. Critical System Component

Research and Development

Heat exchanger research and

development contracts

Mod 0 heat exchanger design and

fabrication contzacts

$x($ In Work)

$x(1975)$

a/Estimate through test of 100uwe Commercial Demonstration Model in $198 j$ 
U. S. ENERGY RESEARCH AND DEVELOPMENT AD:INISTRATION

PROGRAM OUTPUTS

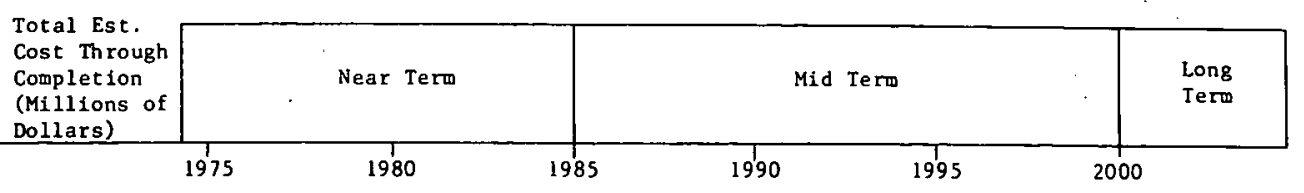

Volar Electric Applications (cont.)

D. Ocean Thermal Energy Zonversion (cont.)

Decision Points Anticlpated (cont.)

3. Critical System Components

Research and Development (cont.)

Research and derelopment con-

tracts on turbines, pumps, anchor-

ing/mooring/dynamic positioning

deep water plpe, materials, corro-

sion blofouling and screening

Mod 1 heat exchanger destgn and

construction contracts

$x(1975)$

Systems engineering study of anchor-

ing/mooring dynamic positioning

Contracts for prototype and long-

lead time pumps, turbines and

$x(1977)$

$X(1977)$

4. Floating Prototype Module A

Preliminery Design Contracts (2)

for 100Mwe Floating Plat form and 25MW

Power Module (hill to be full size,

surface and semi-submersible option

$x(1978)$

to be investigated)

$x(1979)$ 
U. S. ENERGY RESEARCH AND DEVELOPMENT ADMINISTRATION PROGRAM OUTPUTS

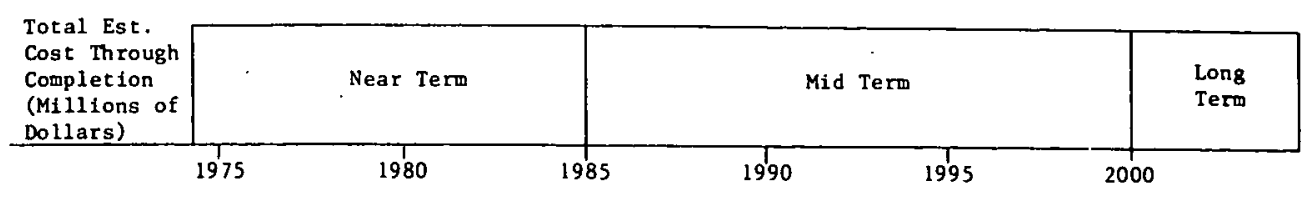

V. Solar Electric Applications (cont.)

D. Ocean Thermal Energy Zonversion (cont.) Decision Points. Anticipated (Cont.)

4. Floating Prototype Module A (cont.) Contract for Purchase of Long-Lead Time Materials and Equipment for Prototype 100mis Floating Plant

Contract for Construction of Hull

$X(1980)$

and In1tfal Power Module

$x(1981)$

5. Demonstration Pover Station

Contract for Pcuer Modules for

Hu11 w111 be Retrofitted with B

Modules)

$X(1982)$

6. Advanced BesearcB and Technology

Study Contracts on Energy Delivery,

Product Mix Impact and Siting. Therma

Resources and iegal Consideration

Adminis:ration assistance in establish-

ing platform design requirements) 
U. S. ENERGY. RESEARCH AND DEVELOPMENT ADMINISTRATION PROGRAM OUTPUTS

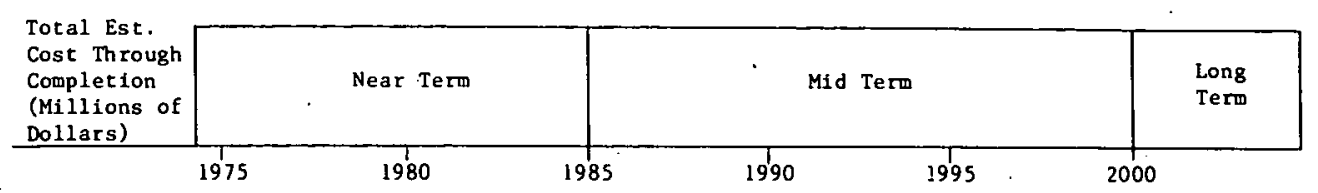

V. Solar Electric Applications (cont.)

D. Ocean Thermal Energy Conversion (cont.) Decision Points Ant1cipated (Cont.)

7. Other Renewable Energy Resources

Contract to Review Potential of Ocean Currents, Waves, Tides and Salinity Grad1ents as Ocean1c Energy Sources

$X(1975)$

Major Results Expecied

1. System Studies

2. Test Facllities

Fac1lity design completed

First phase compliated

Second phase completed

$\bullet(1976)$

-(1977)

-(1978)

3. Critical System Components Research and Develorment

Fabrication of Moc 0 heat exchanger Initiated 
U. S. ENERGY RESEARCH AND DEVELOPMENT ADMINISTRATION PROGRAM OUTPUTS

\begin{tabular}{l|l|l|l|l|}
$\begin{array}{l}\text { Total Est. } \\
\begin{array}{l}\text { Cost Through } \\
\text { Completion } \\
\text { (Millions of } \\
\text { Dollars) }\end{array}\end{array}$ & Near Term & & Mid Term & $\begin{array}{l}\text { Long } \\
\text { Term }\end{array}$ \\
\hline
\end{tabular}

v. Solar Electric Applicatior.s (cont.)

D. Ocean Thermal Energy Conversion (cont.)

Major Results Expected (cont.)

3. Critical System Components

Research and Development (cont.)

Fabrication of rod $O$ heat exchanger

completed and tests underway

$\bullet(1976)$

Fabrication of Mod 1 heat exchanger

initiated

$\bullet(1978)$

Systems engineering study of

anchoring/mooring/dynam1c posi-

tioning complete

Construction complete and tests Conster

$\bullet(1978)$

$\bullet(1980)$

4. Floating Prototype Module A

Preliminary Design of Prototype
100MW platform and 25MWe Power

Module A complebe

Detalled Design of Prototype 100MW

platform and 25M Power Module A

complete

(1979)

-(1981) 
U. S. ENERGY RESEARCH AND DEVELOPMENT ADMINISTRATION PROGRAM OLTTPUTS

\begin{tabular}{l|ll|l|l|l|}
$\begin{array}{l}\text { Total Est. } \\
\text { Cost Through } \\
\begin{array}{l}\text { Completion } \\
\text { (Millions of } \\
\text { Dollars) }\end{array}\end{array}$ & Near Term & & & Mid Term & $\begin{array}{c}\text { Long } \\
\text { Term }\end{array}$ \\
\hline 1975 & 1980 & 1985 & 1990 & 1995 & 2000
\end{tabular}

v. Solar Electric Applications (cont.)

D. Ocean Thermal Energy Conversion (cont.)

Major Results Expected (cont.)

4. Ploating Prototype Module A (cont.)

Test and Evaluation of Prototype

$100 \mathrm{MW}$ Platform and 25MW $\mathrm{e}$ Power

Module Commences

$\bullet$ (1983)

5. Demonstration Power Station

Test of $100 \mathrm{WW}_{\mathrm{e}}$ Demonstration Model

Containing Four Improved B Power

Modules Retrofitted into Prototyp 
U. S. ENERGY RESEARCH AND DEVELOPMENT ADMINISTTRATION PROGRAM OUTPUTS

V. Solar Electric Applications (cont.)

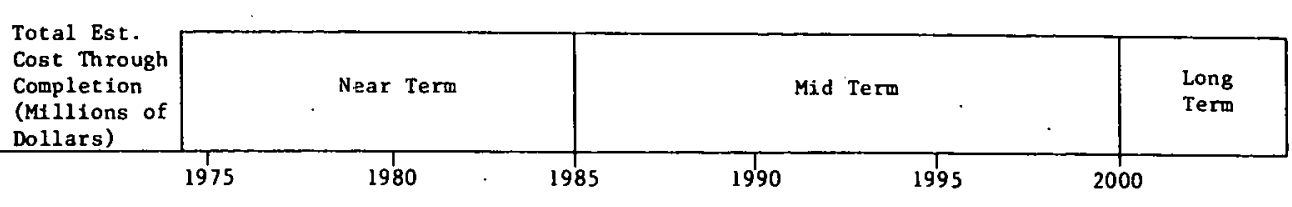

D. Ocean Thermal Energy Cor.version (cont.)

Major Results Expected (cont.)

4. Prototype Flaating Eower Plant (cont.)

Test and Evaluaticn of Prototype

100MWe hull and 2 MW Power

Module Commences

$\bullet$ (1983)

5. Commercial Demonstration Power Station

Test of $100 \mathrm{MWe}$ Comercial Demonstration

Model Containing Fur Improved 25MWe

Power Modules Retrofitted 1nto

Prototype Hull 
U.S. ENERGY RESEARCH AND DEVELOPMENT ADMINISTRATIO: PROGRAM PROJECTION SUMMAR

SOLAR ELECTRIC APPLICATIONS (SEA) PROGRAM

Operating Expenses.............

Capital Equipment..............

Plant (With Escalations).........

Total SEA Program (With Piant

Escalations ) ..................

$$
\begin{array}{r}
\text { Es } \\
\text { FY } \\
\hline 27.0 \\
0 . \\
- \\
\hline 27 .
\end{array}
$$

Est. FY $1976 \quad$ Transition

$\begin{array}{lll}\text { Est. } & \text { FY } 1976 & \text { Period } \\ \text { FY } 75 \text { Cong. Rev. }\end{array}$

0.5

$-$

Ta

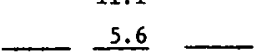

$3.3 \quad 37.3$

40.7

FUNDS FROM OTHERS (not added to
ERDA total)

Funds from other agencles and programs.

National Science Foundation-'

U.S. Departmeat of Defense
Joint Participation by Utilitieg

Total Solar Electric Applications Funds

$\overline{F Y}$

FY

Progra

FY 79 FY 80 $\overline{F Y} \overline{81}$

Whe Completion

$\begin{array}{lllll}37.3 & 46.0 & 58.0 & 66.2 & 89.1\end{array}$

$38.9 \quad 52.9 \quad 73.6 \quad 149.6 \quad \underline{274.5}$

From Others

SPECIAL FUNDING REQUEST (For FY 1976 and

To Fund cooperative ERDA-Department of Defense (DoD) 2.0

$\frac{0.8}{0.8}$

$\begin{array}{llllll}23.3 & 215.8 & 267.4 & 331.1 & 430.7 & 604.1\end{array}$

192.6

$\underline{1092.2}$

Energy Self-Sufficlency Demonstration

a/ Funds provided For advanced ocean thermal conversion studies.

b/ Anticipate utility paricipation of up to $50 \%$ for demonstration facilities. 
Operating Expenses..............

Capital Equipment..............

Plant (1977 Dollarsj............

Total SEA Program (1977 Do.llars).

U.S. ENERGY RESEARCH AND DEVELOPMENT ADMINISTRATION

PROGRAM PROJECTION SUMMARY
(Dollars In Millions)

SOLAR ELECTRIC APPLICATIONS (SEA) PROGRAM

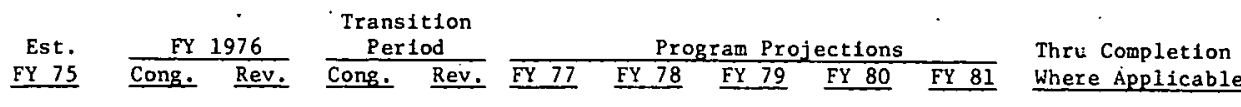

192.6 
U. S. ENERGY RESEARCH AND DEVELOPMENT ADMINISTRATION

PROGRAM PROJECTIONS

SOLAR ELECTRIC APPLICATIONS (SEA) PROGRAM

\section{OPERATING EXPENSES-}

A. Solar Thermal

B. Solar Photovoltaic Conversion

c. Wind Energy Conversion.

D. Ocean Thermal Eaergy Conversion

Total Solar Electric Applica:ions

Operating Expenses

\begin{tabular}{|c|c|c|c|c|c|c|c|c|c|c|}
\hline \multirow{2}{*}{$\begin{array}{r}\text { Est. } \\
\text { FY } 75 \\
\end{array}$} & \multicolumn{2}{|c|}{ FY 1976} & \multicolumn{2}{|c|}{$\begin{array}{c}\text { Transition } \\
\text { Perlod }\end{array}$} & \multicolumn{5}{|c|}{ Program Projections } & \multirow{2}{*}{$\begin{array}{l}\text { Thru Completion } \\
\text { Where Applicable }\end{array}$} \\
\hline & Cong. & Rev. & Cong. & Rev. & EY 77 & FY 78 & FY 79 & FY 80 & FY 81 & \\
\hline 10.0 & & 28.0 & & 6.1 & 46.0 & 54.1 & 66.2 & 77.4 & 77.0 & $150.2^{b /}$ \\
\hline 7.5 & & 25.4 & & 6.6 & 62.6 & 83.7 & 102.4 & 105.9 & 139.0 & $354.8^{c /}$ \\
\hline 6.5 & & 13.3 & & 3.5 & 17.6 & 17.2 & 12.8 & 11.1 & 5.1 & $5.9^{\mathrm{d} /}$ \\
\hline 3.0 & $\ldots$ & 6.9 & $\ldots$ & 1.8 & 13.4 & 13.5 & 18.1 & 20.5 & 19.4 & $57.1^{\mathrm{e}}$ \\
\hline 27.0 & & 73.6 & & 18.0 & 139.6 & 168.5 & 199.5 & 214.9 & 240.5 & 568.0 \\
\hline
\end{tabular}

a/In FY 1977 dollars with 8\% escalation rate from FY 1976

b/Through 1 year of operation of $100 \mathrm{MW}$ e Demonstration plant in 1987

c/Through large scale production decisions in 1985

d/Through 1 year of operation of large scale system in 1986

e/ Through 1 year of test of $-00 \mathrm{MW}_{\mathrm{e}}$ Conmercial Demonstration Model in 1985 
PROGRAM PROJECTIONS (Continued)

SOLAR ELECTRIC APPLICATTOY'S (Continued)

Est. FY 1976 $\quad \begin{gathered}\text { Transition } \\ \text { Period }\end{gathered}$

CAPITAL EQUIPMENT (BUDGET AUTHORITY) a/ FY 75 Cong. Rev. $\frac{\text { Period }}{\text { Cong. Rev. }}$

Computers (less than $\$ 500,000$ )

Other Equipment

Total Solar Electric Applications

Equipment $\underline{0.5}$

0.5
0.1

11.0

11.1

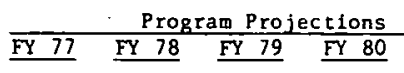

0.2

$3.3 \quad 37$

$3.3 \quad 37.5$
- $\quad 0.2$

46.0

46.0

$\begin{array}{llll}6.0 & 58.0 \quad 66.2 \quad 89.1\end{array}$
Thru Completion Where Applicable

1.5

192.6 
PROGRAM PROJECTIONS (Continued)

SOLAR ELECTRIC APPLICATEONS (Continued)

\begin{tabular}{|c|c|}
\hline PLANT (BUDGET AUTHORITY & $\underline{\text { TEC }}$ \\
\hline \multicolumn{2}{|l|}{ New Profects $\underline{\text { a }}$ / } \\
\hline \multicolumn{2}{|l|}{ Solar Thermalb/ } \\
\hline Central Recelver Power Plant & 296.6 \\
\hline Solar Thermal Test Facllittes & 20.1 \\
\hline Solar Total Energy Systems & 105.5 \\
\hline $\begin{array}{l}\text { Distributed Collector Power } \\
\text { Plant }\end{array}$ & 28.6 \\
\hline Hybrid Solar Therual Systems & 41.0 \\
\hline \multicolumn{2}{|l|}{ Solar Photovoltafc Conversion } \\
\hline $\begin{array}{l}\text { Large-Scale Silicon-Material } \\
\text { Plant }\end{array}$ & 50.0 \\
\hline $\begin{array}{l}\text { Large-Scale Plant for Automate } \\
\text { Production of Arrays }\end{array}$ & 79.2 \\
\hline
\end{tabular}

Wind Energy Conversion

162.9

Ocean Thermal Energy Conversion

Test Facilities

29.7
(Dollars in Millions)

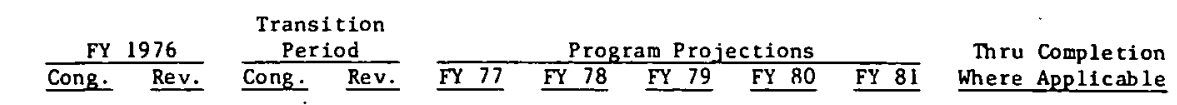

(Continued on Following Page)

\begin{tabular}{|c|c|c|c|c|c|c|c|}
\hline \multirow{3}{*}{0.8} & \multirow[b]{2}{*}{0.8} & 5.0 & 14.7 & 14.4 & 7.5 & 5.0 & 250.0 \\
\hline & & 16.5 & 2.0 & & & & \\
\hline & & 2.8 & 4.4 & 9.8 & 14.6 & 13.9 & 60.0 \\
\hline & & & 6.0 & 4.0 & 10.0 & 6.6 & 2.0 \\
\hline & & & & 4.0 & 8.0 & 12.0 & 17.0 \\
\hline & & & & & 12.0 & 12.9 & 25.1 \\
\hline & . & & & & 18.1 & 19.3 & 41.8 \\
\hline . & & & 10.1 & 24.8 & 42.6 & 32.1 & 53.3 \\
\hline
\end{tabular}

4.8

$\begin{array}{lll}1.2 & 14.6 & 9.1\end{array}$ 
PROGRAM PROJECTIONS (Con $\geqq$ Inued)

SOLAR ELECTRIC APPLICATI JNS (Continued)

PLANT (BUDGeT AUTHORI TY) (cont.) TEC $\frac{\text { FY } 1.976}{\text { Cong. Rev. }} \frac{\begin{array}{c}\text { Transition } \\ \text { Period }\end{array}}{\text { Cong. Rev. }}$

$\underline{\text { TEC }}$

FY 1.976

Ocean Thermal Energy Conversion (cont.)

Critical System Components

Research 8 Develcpment

23.2

Floating Prototype Module A 435.0

Demonstration Plan-

417.5

Total Solar Electric Application Plant
417.5

1689.3

\section{(Dollars in Millions)}

\begin{tabular}{lllll}
\multicolumn{4}{c}{ Program Projections } & Thru Completion \\
\hline FY 77 & FY 78 & FY 79 & FY 80 & FY 81 \\
Where Applicable
\end{tabular}

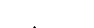

$6.6 \quad 16.6$

\begin{tabular}{|c|c|c|c|c|c|c|}
\hline & & & & & 36.8 & 172.7 \\
\hline & & 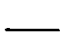 & . & 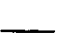 & & \\
\hline 5.6 & 2.0 & 38.9 & 52.9 & 73.6 & 149.6 & 274.5 \\
\hline
\end{tabular}

a/ All profect costs basef on prelimirary estimates, escalation factors over the period of construction schedule use FY 1975 as the base years: $1.11 \mathrm{f} 3 \mathrm{r}$ FY 76 ard transteton period, 1.22 for FY $77,1.3$ for FY $78,1.38$ for FY $79,1.47$ for FY $80,1.57$ for FY 81 and 1.67 for following years.

b/ Utilities are anticipazed to contribute as much as 50\% to demonstration and commerclal plant developments. 